ZBIÓR WAŻNIEJSZYCH DOKUMENTÓW NATURY KOŚCIELNEJ ARCHIDIECEZJI GNIEŹNIEŃSKIEJ

DO LAT 1818/1821

OPRACOWAE I WYDAE

KS. STANISEAW LIBROWSKI

\title{
CZEŚSĆ 3 OŚRODEK ŁOWICZ
}


Piza, 7 lipca 1136

Innocenty II papiė், na prošbe Jakuba ze Żnina arcybiskupa gnieźnieńskiego, bierze pod swoja opieke archidiecezje gnieźnieńska, potwierdzajqc jej uposażenie, m.in. Lowicz z okolica.

- - item Louiche cum decimis, cum villis et earum incolis, cum venatione, cum castoribus et cum omni penitus iuridicione seculari, nulli preter episcopum respondere habet - - -

Lit. Z. Kozlowska-Budkowa: Repertorjum polskıch dokumentów doby pqastowskie\}, z. I: Do końca wieku XII, Kraków 1937, nr 37.- Najstarsze papieskie bulle protekcyjne dla biskupstw polskich, cz. I: Bulla gnieźnieńska $z r$. 1136, wyd. O. Łaszczyńska, Poznań 1947, s. 15.

Uw. 1. Pierwotna nazwa osady Lowisko zostala urobiona na podstawne przesłanek topograficznych, nie tyle od łowów zwierzyny $w$ okolicznych lasach, ile od towienza ryb $w$ bogatych tutaj wodach, na co wskazuje herb miasta - pelikan, karmıqcy się rybami (Miasta polskie w Tysiqclecıu, przew. Kom. Red. S. Pazyra, t. drug?, Wroctaw 1967, tabl. po s. 32).

2. Łowicz, o którym juz tekst powyższej bulli wypowiada sie jako o ośrodku większej wtasności ziemskıj, a moze nawet kasztelanii (Warężak: Słownik, z. 1, s. 184, 206), otrzymat prawa miejskie przed r. 1298 (tamże, s. 184-185).

3. Miasto to az do końca XVIII $w$. byto uważane za centrum najważnesszego

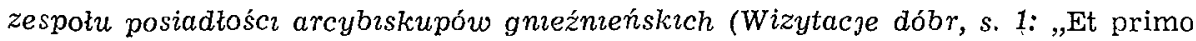
incipiendo a Castellania Lovicensi, que maior et principium omnium est in bonis eiusdem S. Gneznensis Ecclesie" (r. 1511).- J. Waręzak: Osadnictwo kasztelanii Łowıckıej (1136-1847), cz. I, Łódź 1952-S. Pazyra: Geneza i rozwój miast mazoweekich, Warszawa 1959 - o Łowiczu wg skorowidza, s. 440).

4. W roku wystawienia wspom. bulli (1136) w kościele pw. Najśw. Maryı Panny $w$ Łowıczu, przyp. już parafialnym, arcybp Jakub ze Żnina miał konsekrować bıskupa plockiego, wtaściwie najpierw włocławskiego, Wernera (S. Damalewicz: Series archiepıscoporum Gnesnensium, Varsaviae 1643, s. 90.- J. Fijałek: Ustalenıe chronologii biskupów wiociawskich, Kraków 1894, s. 11).

Tenże pierwszy kościót $w$ Łowıczu według tradycji (płyta marmurowa $z$ r. 1668 $w$ kolegnacle towickiej; akta wizytacji gen. wspom. kolegiaty i jej kapituly $z$ l. 1757-1811 - AAW: AAGn, Wiz. 1, s. 55 (r. 1757), s. 93 (r. 1763), s. 157 (r. 1779), s. 221 (r. 1792); ADW: AAGn, Wiz. 141, s. 165 (r. 1811) - zostat zbudowany ok.

* Uwaga. Wszystkie rzeczy wstępne zwiazane $z$ ta częsicia dyplomatariusza (przedmowa, zakres a podstawa wydawnictwa, strona edytorska, skróty, wykaz dokumentów) zostana podane na jej końcu. 
r. 1100, jak dobrodusznie podaje owa dokumentacja, „przez ksiazat mazowiec-

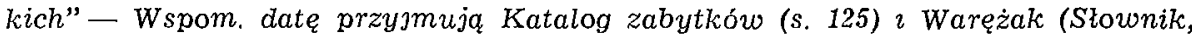
z. 1, s. 199).

\section{2}

Lowicz, 9 października 1404

Mikolaj arcybiskup gnieźnieński funduje i eryguje $w$ Lowiczu, na Nowym Mieście, drugq z rzędu parafię z kościolem pt. Ducha Św., św. Mateusza ap. $i$ św. Katarzyny pm., określajac jej terytorium oraz wyliczając uprawnienia.

Or. nie znany.

Wp. AAG: Liber beneficiorum ( $z r .1523)$, rps.

Wyd. Liber beneficiorum, $t$. II, s. 255-256.

Reg. 1. Wizytacje dóbr, s. XXXVIII, nr 174.

2. Tamze, s. 17.

Lit. Gawarecki: Pamiatki, s. 141-142,- Korytkowski: Arcybiskupi, t. I,

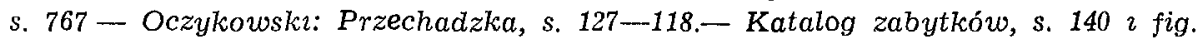
102.- Waręzak: Slownik, z. 1, s. 200.

In nomine Domini amen. Ad rei memoriam sempiternam. Cum brevis etas hominum ducatur continue in occasum, sagax prudentum solercia inter humane nature commoda nichil dignius memoria fore arbitrans opportunum contra oblivionis fomitem et memorie naufragium remedium advenit, ut pensata labilitate recordancie vota laudabilium donacionum scripturarum testimonio roborentur. Proinde nos Nicolaus Dei gracia S. Ecclesie Gneznensis archiepiscopus 1 notum facimus universis, tam presentibus quam futuris, presencium noticiam habituris, quod felicis tempore nostri regiminis, quantum Deo propicio possumus, gloriam cultus divini in civitate nostra Lovicensi et eandem civitatem Lovicensem in pluralitate habitancium pro viribus ampliare cupientes ${ }^{2}$, ecclesiam novam parochialem ad laudem et honorem Omnipotentis Dei et presertim Spiritus S., necnon b.

2. a Mathrae $L B$.

2. 1 Mikolaj z Kurowa pod Bochnza (Kurowski) h. Szreniawa, ok. 1355-1411, bak. sztuk wyzw. 1385, dr ob. prawa; kantor gneźnıeński przed 1395, protonotariusz król.,

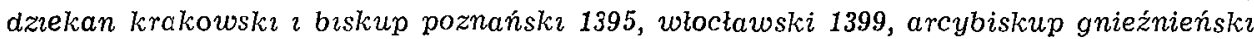
1402, regis vicarıus in Regno 1410. Czynny na polu koścrelnym ¿ państwowym (Eętowski: Katalor, t. III, s. 220-224.- Korytkowsk : Arcybrskupi, t. I, s. 764-792, t. V, s. 322-323.- Fijalek: Ustalenie, s. 41-45.- Szostkiewrcz: Katalog, s. 106.- Nowacki: Archidiecezja, t. II, s. 76-77.- PSB (J. Krzyzanıakowa), t. XVI (1971), s. 261-262).

2 Utwarzente $w$ r. 1404 parafii dla Nowego Miasta az nadto śwradczy, ze juz na przet. XIV/XV w., a nie dopiero na pocz. XVI, jak podaje Warężak (Slownik, z. 1, s. 185), Eowicz stitadat sie z 3 dzielnı: Starego Miasta, Nowego Miasta i Podgrodzza, pozostalego po $1404 w$ parafii macıerzystej 2 korzystajacego równeż $z$ kościola pt. św. Jana Chrzciciela (Oczykowski: Przechadzka, s. 116).- Zob. przyp. 19-20. 
Mathei ${ }^{a}$ ap. et ev. ${ }^{3}$ ac s. Catharine $v .^{4}$ per venerabilem fratrem nostrum, dominum Ioannem episcopum Lidoricensem suffraganeum nostrum ${ }^{5}$, fundavimus et ereximus, fundari quoque et erigi fecimus, de nostra sciencia speciali discretum Paulum Clementis de Ribno presbyterum Poznaniensem ${ }^{6}$ eidem ecclesie nove S. Spiritus in Lovicz preficiendo in rectorem, curam spiritualium et temporalium ac regimen animarum in dicta ecclesia nova sibi committentes. Attento itaque, quod spiritualia sine temporalibus non possunt subsistere ac de congrua sustentacione rectoris eiusdem ecclesie pro tempore volentes paterna provisione sollicite providere, decimas mense nostre archiepiscopalis in Zelkovycze ${ }^{7}$ et in Nova Civitate Lovicz de agris noviter exstirpatis et in futurum ibidem exstirpandis, ac eciam duos mansos agrorum ibidem ante Novam Civitattem exstirpandorum predicte ecclesie nove S. Spiritus et s. Mathei a ap. et ev. ac s. Catharine v. in Lovicz per nos fundate et erecte, et rectori eiusdem ecclesie pro tempore pro sua competenti et congrua sustentacione, sub ratihabicione venerabilium fratrum nostrorum dominorum Capituli videlicet Gneznensis ${ }^{8}$; necnon dictam Novam Civitatem Lovicz et Longam Plateam ${ }^{9}$ in Antiqua Civitate Lovicz, incipiendo a ponte ${ }^{10}$ et Ianusyno Szychultowycz ${ }^{11}$ versus et usque ad ecclesiam $\mathbf{S}$. Spiritus supradictam, et eciam villas Barthkovycze ${ }^{12}$, Yastrzebya ${ }^{13}$, Yamno ${ }^{14}$, Pyelaskovo ${ }^{15}$, Domkovycze ${ }^{16}$, Ostroph ${ }^{17}$ et Otho-

3 Sw. Mateusz apostol $i$ ewangelista, zyjacy $w 1$ poł. I $w$. Swięto 21 września.

4 Sw. Katarzyna $z$ Aleksandrii $w$ Egıpcie, panna $i$ męczennzca, ścręta za wrare ok. r. 305. Swęto 25 listopada.

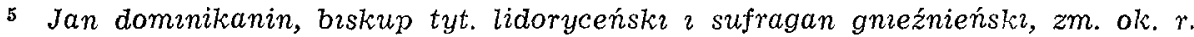
1411 (Szostkewicz: Katalog, s. 82).

6 Pawel s. Klemensa z Rybna, wsi kościelnej dek. sochaczewskıego, daw. $w$ diec.

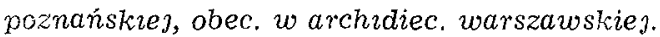

7 Zielkowice, wieś w par. kolegıackiej w Lowiczu (Rocznik 1958, s. 307).

8 W myśl przepısów prawa koścıelnego m.in. utworzenie nowes parafii, zatożenıe

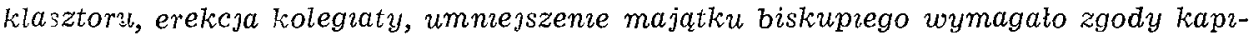
tuly kat., w tym przypadku metrop. gnzeźnıeñskıej.

${ }^{9}$ Ul. Dluga w Łowiczu znana byla $w$ ciagu calej hrstorii tego masta (Oczyłowski: Przechadzka, s. 127).

10 Chodzi tu o jedyny wtenczas, czy tez glówny most $w$ Łowıczu, do którego późnie j prowadziła ul. Mostowa (Oczykowski: Przechadzka, s. 56).

11 Janusz Szychultowıcz, pewne kupıec pochodzenıa ormıańskıego $w$ rozwıjajacym się Eowiczu.

12 Wieś Bratkowıce, $z$ bregiem czasu rozbudowana $w$ przedmieście Łowıcza (Warezak: Slownik, z. 1, s. 66, 187).

13 Jastrzębia, wreś na ter par. Ducha Sw. w Eowiczu (Rocznik 1958, s. 316.Warezak: Slownik, z. 1, s. 128-131).

14 Jamno, wieś $w$ par. Ducha Sw. w Eowiczu (Rocznik 1958, s. 316.- Warężak: Stownik, z. 1, s. 118-121).

15 Pilaszków, wieś na ter. par. Ducha Sw. w Eowıczu (Rocznik 1958, s. 316.Warężak: Stownik, z. 2, s. 47-49). 
lycze ${ }^{18}$ eldem ecclesie propinquas et vicinas, pensantes inter nos, quod rector s. Marie Virginis de Antiqua Lovicz ${ }^{19}$ preter eandem Civitatem Novam, Plateam et villas supradictas de eadem antiqua ecclesia sua potest habere sustentacionem sufficientem ac eciam condecentem, pro parochia et quoad ius parochiale addimus, annectimus, appropriamus, incorporamus et perpetuis temporibus invisceramus, volentes et presentibus statuentes, guod homines Nove Civitatis Lovicz ac Platee et villarum predictarum in ipsa nova. ecclesia S. Spiritus divina de cetero audiant officia et ecclesiastica percipiant sacramenta ibique ecclesiasticam perpetuo habeant sepulturam. In recompensam autem dicte antique platee novam plateam, qua itur de s. Ioanne ${ }^{20}$ ad Antiquam Civitatem, ecclesse antique et matrici adiungimus et incorporamus per presentes. Harum quibus nostrum et dicti Capituli nostri sigilla appensa sunt testimonio litterarum. Actum et datum in castro nostro Lovicz ${ }^{21}$ ipso die Dionysii et sociorum eius martyrum beatorum ${ }^{22}$ anno Domini millesimo quadringentesimo quarto. Transivit per manus Kyelczy cancellarii ${ }^{23}$.

\section{3}

Gniezno, 30 grudnia 1411

Kapituła meiropolitalna gnieźnieńsła prosi Mikołaja arıybiskupa halickrego i postulata gnieźnieńskiego, żeby przywrócit kaplicy pw. św. Marii Magdaleny na zamku towickim wsie Biędów i Wolę Blędowska, należace

16 Dabkowice, wieś w par. Ducha Sw. w Eowiczu (Rocznik 1958, s. 316.-Waręzak: Stownik, z. 1, s. 79-82).

17 Ostrów, wieś na ter. par. Ducha Sw. w Eowıczu (Rocznik 1958, s. 316.- Waręzak: Stownik, z. 2, s. 35-37).

18 Otolice, wieś $w$ par. Ducha Sw. w Eowıczu (Rocznik 1958, s. 316.-Warężak: Slownik, z. 2, s. 38-40).

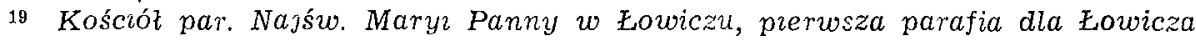
¿ okolıcy, macierzysta dla par. Ducha Sw. Por nr 1, uw. 4.

20 Koścıó szpit. pw. św. Jana Chrzcicıela w Eowıczu, poza miastem. Liber bene-

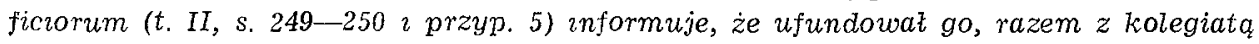

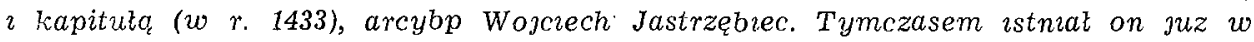
r. 1404, a Jastrzębec podnióst go do rang prepozytury prostej (zoó. nr 5). Zatem jego poczqtek trzeba odnıeść przynajmniej do 2 poz. XIV $w$.

21 Zamek $w$ Łowiczu, przyp. $w$ miejscu daw. grodu ksiazęcego, zbudowaz ok. r. 1355 arcybp Jaroslaw ze Skotnitk (Katalog zabytków, s. 150.- Waręzak: Słownik, z. 1, s. 206).

22 Sw. Dionzzy, pnerwszy bısinup Paryza, zostat ścı̨ty w końcu III w. razem

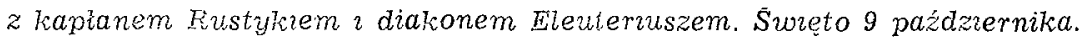

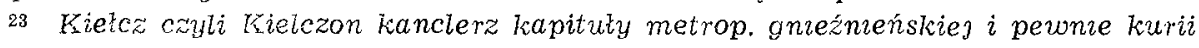
arcybpa Krurowskzego w t. ok. 1404-1411 (Korytkowski: Pralaci, t. II, s. 249). 
do uposazenia jej reitora, pozostajace nieprawnie w rekach archidiakona gnieźn. Miroíaja.

Wyd. Acta capriulorum et uudicrorum, vol. I, nr 1479.

- - Item decreverunt [domsnı prelatı et canonici], quantum potuerunt, auod dominus $N$ [icolaus] archidiaconus Gneznensis ${ }^{1}$ Blandowo ${ }^{2}$ et Wola Blandowska ${ }^{3}$, que villas, prout constat eis, sunt de fundo capelle s. Marie Magdalene ${ }^{4}$ in Castro Lovicens1 ${ }^{5}$, rehabeat, quibus dicta capella et dominus Nicolaus Strzesconis, tunc rector eiusdem ${ }^{6}$, per dominum N[icolaum] condam archiepiscopum ${ }^{7}$, ante renunciacionem per eum factam, fuerat spoliatus, gaudebat, et comiserunt nunciis ${ }^{8}$ euníibus a. dominum. postulatum ${ }^{9}$, quod dictam villam restituat; et ex eo dominus N[icolaus] archidiaconus recessit a monicione, quam fecerat contra dominos de $\mathrm{Ca}$ pitulo. - -

\section{4}

Wr. 1414

Mikołaj arcybiskup gnıénieński eryguje w Łowiczu klasztor Dominikanów z kościotem pt. Trójcy Sw., dodając dlań od siebie pewne fundacje do istotnych, które poczynili w ostatnich latach jego poprzednik - arcybislcup Kurowski oraz inni dobrodzieje.

3. 1 Mikołaj archrdiakon gnieźnieński występujqcy w l. 1409-1423 (Korytkowsłi: Prakacr, t. III, s. 3).

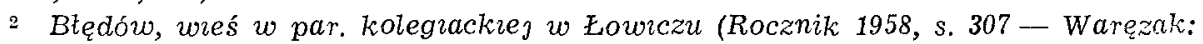
Slownik, z. 1, s. 43--46).

3 Wola Btędowska, wieś obec. połązona z Blędowem albo zagrnıona.

4 Sw. Marna Magdalena, pokutnica zyjaca w 1 poz. I $w$. Swięto 22 lipca.

5 Kaplica zamkowa $w$ Łowiczu zostala erygowana prawdop. juz przez arcybpa Jarosława ze Skotnik, wkrótce po wystawıeniu (ok. r. 1355) przez nzego tamt. zamku. Por. ni 2, przyp. 21.

- Mikotaj s. Strzeszka $z$ Eagrewnik mistrz dekretów, kanonik a nast. kustosz gneźnzeńskı, skarbnik archidiecezjalny 1394-1399, wikariusz kapitulny 1393-1396

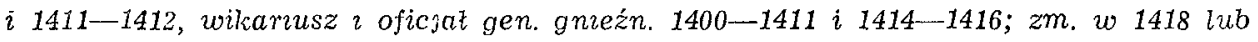
1419 (Korytkowsku: Pratacı, t. IV, s. 22-26).

7 Mikolaj Kurowski (zob. nr 2, pr yp. 1) odebrat synowi Strzeszka (przyp. 6), jego synekure towicka, jak wynika $z$ tekstu, niedtugo po objęcru przez siebie urzędu arcybiskuprego (1402), 2 to niekoniecznie $z$ powodu zlego do nrego nastawrenia. .

8 Kapıtuła metrop. gnieźnıeńska, wybrawszy 28 grudnıa 1411 r. manowanego przez króla Wladysława Jagiellę na arcybiskupstwo gnieźn. arcybpa halickiego Milcotaja Trabę, wyprawita do postulata postów $w$ osobach: dra prawa Bliborıusza, Míko-

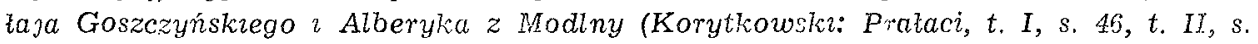
105, t. III, s. 34-35.-- Acta capitulorum et zudiczorum, vol. I, nr 1473-1474).

$9 \quad$ Mikolaj Traba-zob. nr 4, przyp. 3. 
Or. nie znany. Ogladal go $w$ r. 1511 wizytator posiadtości arcybiskupich kanonik gnıeźnieńskı Klemens Busıński, który sporządzit obszerny jego regest (ni$z e j 2)$.

Reg. 1. Wizytacje dobr, s. XL, nr 189.

2. Tamze, s. 18.

Wyd. (reg. 2). Wizytacje dóbr, s. 18.

Lit. Gawarecki: Pamiatki, s, 164.- Korytkowski: Arcybıskupi, t. I, s. 791.Oczykowskı: Przechadzka, s. 102.- Katalog zabytków, s. 142.- Waręzak: Słownik, z. 1, s. 200.

Uw. 1. Żr. rękopiśmienne i lit. przedmiotu jako datę zalożenıa tego klasztoru podaja zwykle r. 1400, chociaż rzady arcybpa Kurowsknego rozpoczęty się $w 1402$.

2. Klasztor i kościót przeszly na cele świeckie ost. po r. 1818.

Ecclessa S. Trinitatis Fratrum Predicatorum fundata et dotata infra contentis. Et prımo archiepıscopus Gneznensis et Cracoviensis, Ploczensis ecclesiarum episcopi sunt conservatores Religionis S. Dominici a Sede Apostolica delegat1. Fundavitque Ecclesiam S. Trunitatis in Lowicz olim rmus dominus Nicolaus archiepiscopus Gneznensis primus ${ }^{1}$ nonnullisque literis premunivit ${ }^{2}$. Sed secundus Nicolaus archiepiscopus ${ }^{3}$, literis suis duntaxat sigillo suo roboratis, fundacionem prioris Nicolal confirmavit, donacionem aree ac ortus pro edificanda ecclesia et conventu per olim Benedictum de Modlna archidiaconum Lanciciensem ${ }^{4}$ dicti archidiaconatus ${ }^{\tilde{a}}$ aream et orthum donatos ${ }^{a}$ roboravit. Necnon Albertus de Byelawi scolasticus ${ }^{6}$ pro edificiis sumptus impendit. Et tandem Nicolaus advocatus Lowiczensis ${ }^{7}$ aream et orthum dicto monasterio adiunxit, assignavit et in-

4. a donatas wyd. b redemptas wyd.

4. 1 Mikolaj Kurowski - zob. nr 2, przyp. 1 .

2 Dokumenty Kurowskiego $w$ tej sprawie nie sa znane.

3 Mikolaj (Traba) h. Traby, 1358-1422, kapelan, notaruszz król., podkanclerzy dworu 1404-1412. Kanonik krakowskı przed 1386, gnieźnieñskı przed 1407, wtoctaw-

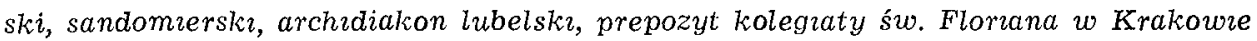
ok. 1402. Arcybıskup halickı 1410, gnieźnieńskı 1412. Czlonek rady król., uczestnik Soboru $w$ Konstancji 1414-1418, skąd wywrózł tytut prymasa dla arcybiskupów gnieźn. Wielce zastuzony dla Koścrota ı Państwa (Statuty synodalne wreluñsko-kaliskze M. Trąby $z$ r 1420, wyd. J. Fijatek, A. Vetulanı, Kraków 1915-1951.- Eętowskı: Katalog, s. 157-169.- Korytkowskı: Arcybıskup , t. II, s. 1-75, t. V, s. 334-335Wiśnıewskı: Katalog, s. 299.- Szostkıewrcz: Katalog, s. 183.- T. Silnıcki: Arcybrskup M. Traba, Warszawa 1954,- Hajdukiewncz: Histora, s. 700-701).

4 Benedykt s. Macıeja z Modlny, wsi kościelnej w dek. ozorkowskim, archıdia-

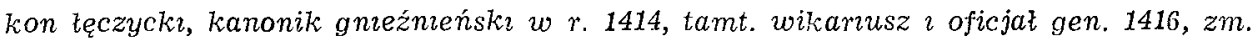
po 1426 (Korytkowski: Pratacr, t. I, s. 42).

5 Pralacı architsolegraty lęczyckıe dlatego odgrywaja $w$ nin. dokumencre wazna rolę, ze Eowrcz w owym czasie nalezal do archıdiakonatu tęczyckıego.

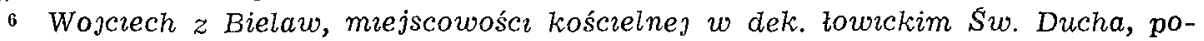
chodzit z rodu Zarembów, który przyją nazwısko Bielawskich. Kanonik gnieznıeński przed 1384, scholastyk lęczyckı 1408. Ok. 1427 fundowaz w koścıele par. w Bielawach kolegıum mansjonarzy; zm. w 1429 (Korytkowskı: Prazaci, t. I, s. 42-44). 
corporavit. Que omnia sine consensu Capituli [Gneznensis] ${ }^{8}$ facta fuerunt. Tandem idem rmus dominus Nicolaus secundus aliam aream et orthum adiunxit, redemptos ${ }^{b}$ apud Konathczanka ${ }^{9}$ sic dicta, que omnia simul iuncta incorporavit et in fundacionem ereccionis invisceravit, obligando dictos religiosos in hoc conventu residentes his oneribus: pro Nicolao archiepiscopo primo, predecessore et secundo, fundatore ac aliis predecessoribus archiepiscopis et successoribus Gneznensis Ecclesie, necnon pro animabus prefatorum dommorum Alberti scolastici, Benedicti archidiaconi Lanciciensis, similiter Nicolai advocati ad memoriam eviternam servandam in memoriis eorum infra Canonem. Et non plura continentur in eo ipso privilegio. Cuius ereccionis acta sunt prescripta anno Domini MCCCCXIV.

Gniezno, 25 kwietnia 1433

Wojciech arcybiskup gnieźnieński i prymas, za zgoda kapituty metrop. gnieźnieńskiej, podnosi do godności kolegiaty kościót par. Najśw. Maryi Panny $w$ Łowiczu, przy którym eryguje kapitule złożonq z 3 prałatów: prepozyt, dziekan, kustosz i 10 kanoników, uposażajac nowych beneficjatów $z$ dóbr stolu arcybiskupiego, wspom. parafii oraz in.; dziekanii inkorporuje par. Piqte?., a kustodii Bałków. Kolegiata pozostaje parafia, a duszpasterstwo $w$ niej maja petnić prataci i kanonicy. Jeszcze nie ma mowy o wikariuszach. Kapituła otrzymuje do pomocy 2 kaznodziejów, pelniacych także obowiazki penitencjarzy, zależnych od niej, oraz rektora szkoty (duchownego), dobieranego przez prepozyta. Wszystkim trzem przystuguje strój kanonicki $i$ miejsca w stallach. Przy tej okazji arcybiskup podnosi kościót szpit. św. Jana Chrzc. do rangi prepozytury prostej, a jego prepozyta wiaże $z$ kolegiata przez strój kanonicki $i$ udziat $w$ jej wystawnych nabożenstwach. Patronat nad prebendami kapitulnymi oddaje arcybiskup swemu staroście zamku i posiadłości towickich, a nad szpitalem miastu.

Or. nie znany.

Wp. AAG: Liber beneficiorum ( $z$ r. 1523), rps.

Kop. 1. AAW: Kopıarusz Janıckiego $z$ r. 1749, s. 20-30. Tytul: Tenor seu cop:a privilegii erectionem et fundationem praelatorum et canonicorum Collegii ad Ecclesiam S. Mariae in Lowicz in se continentis - -

2. AKL: Kopiariusz Sladeckiego sprzed r. 1810, s. 1-17. Tytul: Erectio Ecclesıae B. V. Marıae in Collegiatam Lovicensem 1433.

7 Mikolaj wójt miasta Łowıcza, blize ’ ne znany.

8 Por. nr 2, przyp. 8.

9 Córka mieszczanina low. Konaty, blize nie żnana. 
Wya. 1. Liber beneficrorum, t. II, s. 507-516.

2. Kwiatlowsk : Kapituka, s. 559-568.

Reg. 1. Wizyta.cye dóbr, s. XLII, nr 207.

2. Librowski: Sumariusz, nr 1 .

Wzm. Wizytaçe dóbr, s. 14-16, 17-18.

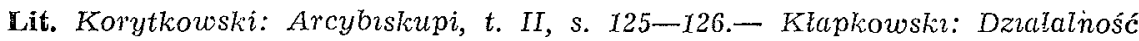

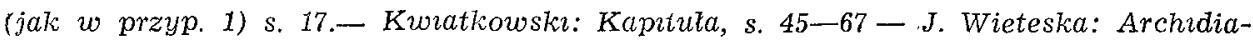

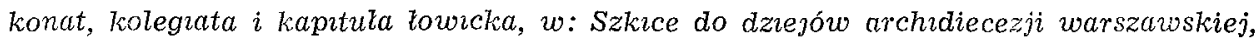
Rzym 1966, s. 75, 86).

Uw. Po erekcji kapatuly w Lounczu tamt. lcoścıól par. Najśzo. Maryi Panny przyjąt nazwę kolegrackzego, a Sw. Ducha (nr 2) - farnego.

In nomine Domini amen. Albertus Dei gracia S. Gneznensis Ecclesie archiepiscopus et primas ${ }^{1}$. Ad rei memoriam sempiternam. Constituti in eminenti speculo vigilancie pastoralis, dum per universi officii nostri ambitum curam omnium, quibus nos occulta. Dei et nobis pavida dignacio pretulıt, intente sollicitudinis passibus circuimus, continuo cordis nostri se offert obtutibus onus supra vires nostre possibilitatis impositum debilibus humeris nostris. Stupor ergo ebetat et tremor concutit animum nostrum, ne sic perimat quod opprimat, sic opprimat quod succumbat mollis immensitate portantis debilitas. Porro quum ceteri sub particulari onere conqueri cogantur, se frequentis ministerii tedio fatigari et querére auxiliorum solacium, attenta meditacione pensandum est, quantis implicamur difficultatibus, quantis afficimur tediis, quantisve premimur angustiis, quum semper intendere cogamur, cottidiana cura subiectis nobis lege diecesana universis, tantoque proinde reddimur attoniti, quanto non de propria solum et ipsa periculosa, sed et de omnium salute superesse nobis cernimus reddendam racionem. Inde est, quod quum necessitas distancie Lovicensis, Ravensis et Langonicensis Diecesis nostre Gneznensis a nostra metropolitana et collegiatis ecclesiis elongatorum districtuum ${ }^{2}$ efflagitet, profectusque commisse nobis plebis in eisdem districtibus degentis persuadeat et zelus salutis urgeat animarum, ut quemadmodum aliarum parcium, quas regit nostra

5. 1 Wojciech Jastrzębiec, $z$ Lubnic $w$ par Beszowa $w$ dek. staszowskin, ok. 13621435. Dr prawa kan., kanonik sandomiersk od $r$. 1385, gneżneńsk 1389 , scholastyk gnieźnieński 1394, krakowski 1397, brskup poznański 1399, krakowskı 1412, arcybiskup

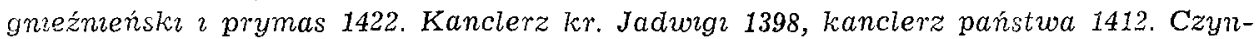

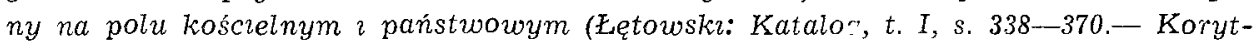
kowski: Arcybrskupı, t. II, s. 76-146; t. V, s. 309.-Wiśnewskı: Katalog, s. 93.W KKtapkowski: Dzıałalność koścılna bıskupa Wojcıecha Jastrzębca, Warszawa

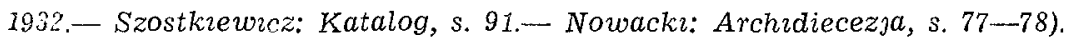

2 Najdale na pótnocny-wschód wysunięte ośrodk koścıelne a gospodarcze archidiecezji: towncki, rawskı 2 tęgonıck byty zespolone $w$ jeden obszerny delcanat rawski, wchodzacy $w$ skiad równiez rozlegtego archıdiakonatu tęczyckiego (Liber beneficiorum, t. II, s. 236-348). Najblizsza kolegrata od strony zachodniej byta dla nich lęczycka, a od poludniowe jurzelowska. 
sollicitudo, populis et eorum commoditatibus salubriter provisum existit, sic et degentibus in eisdem districtibus habitatoribus pastorali solercia prospicere curaremus. Non indigne censuimus in partem ministerii nobis advocare cooperatores strennuos, quorum auxilıo supportaremur a lapsibus, virtutumque muniamur suffragiis et plebs llla solercia dirigatur in dubiis eorumque ducatu per pascua salutaris alımonie gradiens, mereatur introire Dei tabernacula cum celi civibus eterne patrie porticibus fruitura. Quum itaque opidum seu locus Lovicensıs ecclesie et diecesis nostrarum predictarum populositate celebris et ad humane vite commodum uberior fruct1bus in illis partibus habeatur, ecclesiaque parochialis S. Marie Virginıs ${ }^{3}$ opido et loco in eodem ad collacionem, provisionem et quamvis aliam disposicionem nostras pertinens in dote sua sic exubertet, quod eius fructus, reditus et proventus sufficere possunt pro statu decenti ministrorum plurimorum, eapropter habito cum venerabilibus fratribus nostris Capitulo Gneznensi solemi tractatu et, prout tanti negocii qualitas requirebat, sepıus repetito ${ }^{4}$, de predicta ecclesia S. Marie ad honorem, laudem et gloriam Omnipotentıs Dei Patris et Filii et Spiritus Sancti eiusdemque Beatıssime Dei Genitricis Virginis Marie, sub cuius vocabulo ipsa ecclesia specialiter fundata existit et erecta, divinique cultus augmentum ac salutem populi christiani collegiatam fundavimus et ereximus, tituloque alcioris dignitatis illam decoravimus ac fundamus, erigimus et decoramus harum serie litterarum, decernentes quod deinceps et in antea collegialis nominetur et censeatur omnibusque libertatibus, immunitatibus, privilegiis, graciis, indultis, exempcionibus aliisque iuribus pociatur et gaudeat, quibus alie nostrarum Provincie et Diecesis Gneznensis ecclesie collegiate pociuntur et gaudent. Ut autem nostre intencionis affectus perducatur, favente a Domino, ad effectum ipsaque ecclesia titulo collegii decorata ad eius decus et regimen dignitatibus, personatibus, officiis, canonicatibus aliisque ministeriorum titulis pro personis in ea Domino perpetim servituris ordinetur beneficiisque et prebendis ad opus ministrorum datis stabiliatur perpetuo permansura, preposituram, decanatum, custodiam et decem canonicatus cum totidem prebendis distinctis. Duo ${ }^{b}$ quoque predicatorum officia in ea, que - tam ex eo, quod honorabilis vir magister Streschko rector eiusdem ecclesie ultimus, illam obtinens scolasterım Ecclesie Collegiate S. Marie Lanciciensis ${ }^{5}$ dicte diecesis nostre (que dignitas est in ipsa Lanc1ciensi Ecclesia) per nos auctoritate ordinaria sibi collatam, existit pacifice

\footnotetext{
5. a sancte kop. 1, LB, Kwiat. b Domino $L B \quad$ c elus $L B$ d cetero $L B$;

3 O początkach koścroła par Najśw. Maryı Panny w Eowiczu zob. nr 1, uw. 4.

4 O udzıale kapituly metrop. gneźnıeńskıej w rzadach archıdiecezja por. nr 2,

-5 Magister Strzeszko ostatn rektor koścıoła par. Najśw. Mary Panny w Lownczu, który za ustcpienie z niego otrzymal od arcybpa Jastrzębca scholasterię lęczycka.
} prży. 8 . 
assecutus; quam eciam per resignacionem eiusdem Strzeschkonis in manibus nostris sponte de ea factam et per nos admissam et receptam - vaccat. De presenti creamus et ex fructibus, reditibus, proventibus, possessionibus, iuribus et pertinenciis suis ", infra descripitis, de novo constituimus, ordinamus et facimus velut eius precipua fundamenta. Et de ipsis prepositura, decanatu, custodia canonicatibusque et aliis personis infrascriptis, vita et honestate preclarıs litterarumque sciencia eruditis, duximus providendum et tenore presencium providemus. Et primo quidem de prepositura dilecto nobis Stanislao de Rosthovo presbytero ${ }^{6}$ providemus ipsumque eidem ecclesie in prepositum preferimus. Pro cuius eciam successorumque suorum sustentacione congrua et fundo prepositure villam Popowo ${ }^{7}$ cum omni iure et dominio, decimamque in eadem villa et de agris illius pro tempore provenientem, duobus piscatoribus in fluvio Bzura ${ }^{8}$, incipiendo ab area prepositi usque ad aggerem Minoris Zabostowo ${ }^{9}$, ab aliis proventibus eiusdem ecclesie antique dotacionis resecando et separando, assignamus et appropriamus decernimusque ac ordinamus, ipsum Stanislaum et successores suos prepositos Lovicenses in perpetuum de illis pro sustentacione sua debere remanere et esse in futurum contentos; ita tamen, quod pro rectore scole, quem ipse prepositus pro tempore existens eligat et recturam scolarum committat magistro in artibus vel valenti baccalario, si haberi potuerit, alias viro idoneo, qui in trivio scolares pauperes gratis doceat. Duos currus lignorum per kmethones de Popowo eidem rectori scole qualibet septimana de anno in annum assignet. De decanatu vero sic per nos de novo creato, pro cuius fundo et dote necnon decani pro tempore in eo instituendi sustentacione mense nostre archiepiscopalis decimas in villis Voyska ${ }^{10}$ et Mykuli ${ }^{11}$ Diecesis Gneznensis prescripte, de dictorum fratrum nostrorum Capituli Gneznensis consensu, dedimus et appropriavimus damusque et appropriamus honorabili Dobrogostio de Czyechoslavicze presbytero eiusdem diecesis ${ }^{13}$ providimus et presentibus providemus; et insuper attento, quod proventus decimarum earundem ipsi decano pro statu suo minus competenter sufficiant et sint tenues et exiles, de dictorum fra-

\footnotetext{
brak $w$ kop. 1, u Kwrat. e aeterna Kwiat. $\quad \mathrm{f}$ Viskovicze LB, a w przyp. 11

- Stanistaw.z nie znanego obec. Rostowa, czy raczej z Rostkowa $k$. Przasnysza lub z Rostowe $k$. Sierpca, dotychcz. rektor kościola par. $w$ Bqkowie $w$ dek. żychlinskim, pierwszy prepozyt kapituly łowickiej, zm. po $r$ 1440 (Wieteska: Katalog, s. 24).

7 Popów, wieś w par. kolegiackiej w Eowičzu (Rocznik 1958, s. 307.-Waręzak: Slownik, z. 2, s. 57-58).

8 Bzura, daw. Msura, lewy czyli zachodni dopływ Wisły, nad którym lezy Łowrcz.

9 Zabostów Mazy, wieś na ter. par. kolegiackıej w Łowiczu (Rocznik 1958, s 307).

10 Wojska, wieś $w$ par. Wysokienice $w$ dek. rawskim (Rocznik 1958, s. 399).

11 Mikuty, wess na ter. par. Lipce w dek. skiernewickim (Rocznik 1958, s. 424).

13 Dobrogost $z$ Ciechosiawic $w$ par. Piatek $w$ dek. lęczyckim, dotychcz. pleban

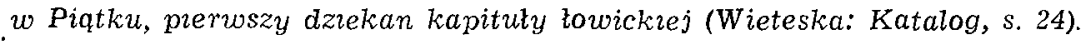


trum nostrorum Capituli Gneznensis consilio et assensu, ecclesiam parochialem in Pyanthek opido mense nostre archiepiscopalis predicte ${ }^{14}$ dicte diecesis, vacantem per resignacionem liberam dicti Dobrogostii in manibus nostris per eum de illa sponte factam et ad collacionem, provisionem omnimodamque disposicionem nostras pertinentem, cum iuribus et pertinenciis suis infrascripis, eidem decanatui anneximus et annectimus per presentes, ita quod decanus pro tempore decimas eiusdem ecclesie in duplici Goslub ${ }^{\mathbf{1 5}}$ et in Coprziwnicza ${ }^{\mathbf{1 6}}$, quas eciam pro dote sui decanatus et decanatu deputamus et incorporamus, habeat et percipiat, decernentes et statuentes, de dictorum ${ }^{\text {d }}$ fratrum nostrorum consensu, presencium per tenorem, ut ecclesia ipsa in Pyantek et cura eidem imminens animarum per vicarium idoneum et perpetuum ad presentacionem decani eiusdem pro tempore, quocies in futurum et quocunque modo eam vacare contigerit, per nos et successores nostros instituendum regatur et in ea deserviatur in divinis. Pro cuius eciam vicarii perpetui pro tempore et ministrorum aliorum ecclesie eiusdem ${ }^{e}$ sustentacione reliquas decimas, fructus, reditus et proventus, videlicet decimas de agris kmethonum in Pyekari ${ }^{17}$ necnon de agris allodiorum nobilium heredum in Lanka ${ }^{18}$ et Sulkovicze ${ }^{19}$, in Boguschycze ${ }^{20}$, in Lubnicza ${ }^{21}$, in Bolkovo ${ }^{22}$, in Rogaschyno duplici ${ }^{23}$, in Gorki ${ }^{24}$, in Wlostovicze ${ }^{25}$ necnon pok ow ne et lapidem cere, in opido Pyantek predicto solvi consueta, ac mansum unum agri, curiam, domum seu dotem in ipso opido, ablaciones et obvenciones alias, preter incorporata superius descrip-

14 Parafia $w$ Piatku, mieścıe arcybıskupım, po rezygnacji $z$ niej wspom. Dobrogosta, weszła w skład uposażenia dziekanii towickiej.

15 Goślub I i II, wsie na ter. wspom. par. Piqtek (Zajaczkowscy: Materiały, cz. I, s. 94.-Diecezja łódzka, s. 231).

16 Pokrzywnica, wieś w tejze par. Piquek (Zajaczkowscy: Materiaty, cz. II, s. 46.Diecezja łódzka, s. 231).

17 Piekary, wieś na ter. wspom. par. Piatek (Zająckowscy: Materały, cz. II, s. 34-35.-Diecezja lódzka, s. 231).

18 Eęka, wieś w tejże par Piatek (Zajączkowscy: Materiaty, cz. I, s. 186-187.Diecezja tódzka, s. 231).

19 Sulkowice, wieś na ter. wspom. par. Piątek (Zajączkowscy: Materiały, cz. II, s. 128-129.-Diecezja tódzka, s. 493).

20 Boguszyce, wieś w tejże par Piatek (Zajaczkowscy: Materaty, cz. I, s. 21.-

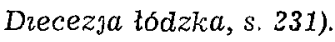

21 Eubnzca, wieś na ter. wspom. par. Piatek (Zajązkowscy: Materzały, cz. I, s. 189.-Diecezja łódzka, s. 231).

22 Balków, wieś w tejże par Piatek (Zajączkowscy: Materiały, cz. 1, s. 4.- Diecezja tódzka, s. 231).

23 Rogaszyn, wześ obec. pojedyncza na ter. wspom. par. Piątek (Zajączkowscy: Materiały, cz. II, s. 70.-Diecezja łódzka, s. 231).

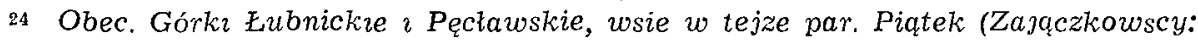
Materaty, cz. I, s. 96.-Diecezja łódzka, s. 231).

${ }_{25}$ Wlostowice, wieś na ter. wspom. par. Piątek (Diecezja tódzka, s. 498). 
ta, interge et perpetue separamus et deputamus. Preterea non minus commoditati et utilitatı, quam tranquilitati et quietı mense archıepiscopalis Gneznensis et decanatus decanique prefatorum prospicientes, pratum magnum hereditatis nostre Pothworzino ante Lowicz situate ${ }^{26}$, quod ad mensam nostram archiepiscopalem spectabat, pro platea seu vico uno in dicto opido Pyantek et prato parvo ante ipsum opidum, que rectores eiusdem ecclesie in Pyantek in ius et proprietatem ipsius ecclesie vindicabant seu vindicare contendebant, necnon decmas mense elusdem archiepiscopalis in vilis Dambowa Gora ${ }^{27}$, Zelazna ${ }^{28}$ et Villkovicze ${ }^{299}$ pro medietate decimarum in dicto opido Pyantek et medietate decimarum in villa mense eiusdem dicta IVrokowicze ${ }^{30}$, quas similiter dicti rectores ecclesie in Pyantek sib1 vindicabant et que ac quas, de consilio dictorum fratrum nostrorum Capıtuli Gneznensis, dicte mense archiepiscopali, consensu ad 1d dicti Dobrogostil tunc rectoris dicte ecclesie in Pyantek expresso accedente, reintegramus et applicamus via et modo commutacionis et recompensacionis pratum ipsum magnum in Pothworzino et decimas in Dambowa Gora, Zelazna et Vilkovicze in ius et proprietatem dicto decanatur et prefato Dobrogostio decano Lovicensi suisque successoribus in perpetuum assignamus et invisceramus per presentes. Item de custodia prescripta sic, ut prefertur, creata Nicolao sacerdoti de Poznania ${ }^{31}$ providimus, et attenta proventuum eiusdem custodie tenuitate, ecclesiam parochialem in Bankovo ${ }^{32}$, vacantem per resignacionem liberam Stanislai de Rostovo rectoris ultimi predicte ecclesie in manibus nostris per eum factam et ad collacionem et disposicionem nostras spectantem, cum iuribus et pertinenciis suis infra descriptis, ipsi custodie, de dictorum fratrum nostrorum Capituli Gneznensis consilio et consensu, anneximus et univimus ac annectimus et unimus per presentes, 1ta quod prefatus Nicolaus suique successores pro tempore custodes Lovicenses racione et nomine eiusdem custodie decimas et proventus ac iura infrascripta: quas, quos et que in dotem iusque et proprietatem custodie eidem et custodibus assignamus et incorporamus, ha-

25 Potworzyn, wieś w par. kolegiackiej $w$ Łowiczu, która pewne weszla w skład tego masta (Waręzak: Stownik, z. 2, s. 58-59).

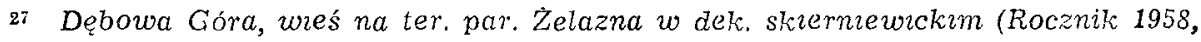
S. 430$)$.

28 Żelazna, wześ i par $w$ dek. skıerniewıckım (Rocznik 1958, s. 430).

20 Wilkownce, wieś $w$ par Wysokıenzce $w$ dek. rawskim (Rocznik 1958, s. 399).

30 Mrokowice czy Mroszkowice, wieś wspom. par. Piatek, zanikajaca juz ok. 1520 (Liber beneficiorum, $t$. II, s. 419).

31 Mikołaj $z$ Poznanza, bak. nauk wyzw., prerwszy kustosz kapituty towrckrej (Wieteska: Katalog, s. 24-25).

32 Par. Bakków w dek. zychlińskzm, po zrezygnowanıu z nej wym. Stanistawa $z$ Rostowa, weszła $w$ sktad uposazenta lkustodii towrckiej. 
beant et percipiant perpetuo; videlicet in Boguria ${ }^{33}$ missales annonas de quolibet manso possesso per unam avene et aliam siliginis mensuras et decimam manipularem ibidem de scultecia, in Rzansno ${ }^{34}$ missalia et de scultecia ibidem unum fertonem Bohemicalium grossorum racione decime, in Viskitnicza ${ }^{35}$ missalia et a sculteto ibidem eciam unum fertonem, et in Dambova Gora decinam manipularem. Proviso similiter et cum dictis fratribus nostris Capitulo Gneznensi statuto, quod ecclesia eadem in Bankowo curaque animarum in eadem amodo et quocies ac quocunque modo illam vacare contigerit, per vicarium idoneum et perpetuum, quem custos pro tempore nobis vel successoribus nostris presentabit, per nos et successores nostros instituendum regatur et deserviatur in divinis in eadem. Pro cuius vicarii sustentacione competentı omnes decımas reliquas fructusque, reditus et proventus, videlicet ibidem in Bankovo duos mansos agrorum cum annonis missalibus de agris rusticorum et quatuor ortulanis ac tribus fertonibus de scultecia necnon de predio nobilium antiquo decimam manipularem, ac per unum grossum de quolibet manso pro columbacione et de Dambova ${ }^{g}$ Gora similiter; in Ostoya ${ }^{36}$ vero de allodiis duorum terrigenarum decimas manipulares ac prata, curiam, domum seu dotem, areas, ortos, oblaciones obvencionesque alias et iura parochialia, preter incorporata superius descripta, interge et perpetuo reservamus et deputamus. Item de canonicatu primo Clementi de Dzerzasna ${ }^{37}$ providimus et decimam in villa Czyrinyevo ${ }^{38}$ de proventibus ecclesie Lovicensis, ab aliis separatam proventibus in prebendam et pro dote canonicatus et prebende suorum eorundem deputamus. Item de canonicatu secundo Divissio ${ }^{\mathrm{h}}$, de Vyewcze $^{39}$ providimus et de fructibus eccleste Lovicensis decimam, ab aliis proventibus eiusdem separatam, in villa Duplice Maiori ${ }^{40}$ provenientem pro prebenda et dotem canonicatus et prebende suorum eorundem deputamus. Item

Wyskienica g Bankova $L B \quad$ h Dionisio kop. 2, Kwat. 1 Ruczki kop. 1, 33 Bogoria, wieś na ter. wspom. par. Baków w dek. żychlinskim (Rocznik 1958, s. 449.- Waręzak: Stownik, z. 1, s. 58-62.-Zajączkowscy: Materiały, cz. I, s. 20).

${ }^{34}$ Rzq̨śno, wies $w$ tejze par. Bąków $w$ dek. zychlińskim (Rocznik 1958, s. 449.Waręzak: Stownik, z. 2, s. 78-80.-Zajaczkowscy: Materiaty, cz. II, s. 80-81).

${ }_{35}$ Wiskıenica, wieśs na ter. wspom. par. Bąków $w$ dek. żychlińskim (Rocznik 1958, s. 449.-Zajaczkowscy: Materialy, cz. II, s. 177).

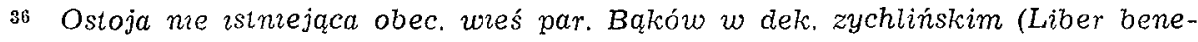
ficiorum, t. II, s. 501, 502.-Zajączkowscy: Materialy, cz. II, s. 19).

37 Klemens $z$ Dzierzaznes, ne wiadomo z które\}, posesor pierwszes kanonii fund.

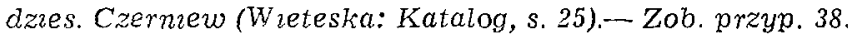

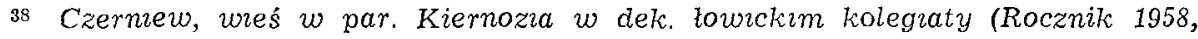
s. 303).

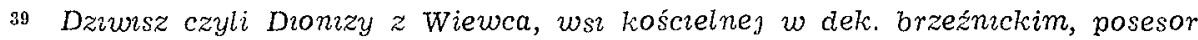
drugıe kanonii fund. dzzes. Duplice Duze (Wietestca: Katalog, s. 25).- Por przyp. 40.

40 Duplice Duze - dzlś Wyborów, wieś na ter par. Zlaków w dek. lownckim kolegiaty (Rocznik 1958, s. 311.-Waręzak: Stownik, z. 1, s. 90-91). 
Iacobo Godzyonowski ${ }^{41}$ de tercio canonicatu providimus et decimam in Mastki ${ }^{42}$ ecclesie predicte Lovicensis, ab aliis separatam fructibus, pro prebenda et pro dote canonicatus et prebende suorum eorundem deputamus et assignamus. Item Mathie Pyeczenya ${ }^{43}$ et Ioanni dicto Baptista ${ }^{44}$ providimus de quarto et quinto canonicatibus, pro quorum prebenda et dote decimas in Syerzniki ${ }^{45}$ et in Vyerzinovicze ${ }^{46}$, villis archiepiscopalibus, eque dividendas assignamus, ab aliis proventibus similiter separantes. Item Ioanni de Rogozno ${ }^{47}$ de canonicatu sexto providimus, pro cuius prebenda et dote decimam in Antiqua Lovicz assignamus. Item de septimo et octavo canonicatibus Nicolao Chmyel ${ }^{48}$ et Alberto de Campina ${ }^{49}$ providimus, pro quorum dote canonicatuum in prebendas duas decimam in Maiori Zlakovo ${ }^{50}$ equaliter per eosdem canonicos pro tempore dividendam et percipiendam assignavimus. Item de nono et decimo canonicatibus Nicolao Crogulyecz ${ }^{51}$ et Bernando ${ }^{52}$ providimus, pro quorum dote canonicatuum in prebendas duas decimam in Minori Zlakovo ${ }^{53}$ similiter per eos dividendam assignamus. Insuper decimas manipulares villarum Svyerzysch ${ }^{54}$ et Iano-

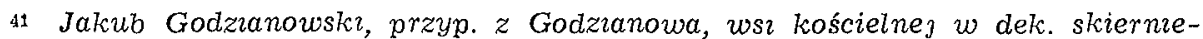

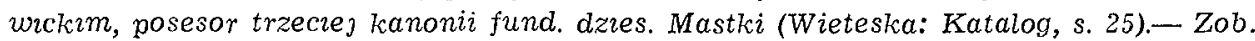
przyp. 42.

42 Mastki, wieś $w$ par. Zlaków $w$ dek. towıckım kolegiaty (Rocznik 1958, s. 311.Waręzak: Słownik, z. 1, s. 244-246).

43 Maciej Pìeczenıa posesor czwartej kanonii, fund. polowy dzies. Sierzniki $i$ Wierznowice (Wieteska: Katalog, s. 25).-- Por przyp. 45-46.

44 Jan zw. Chrzcicielem posesor pratej kanonii fund. drugiej polowy dzıes. Sierz-

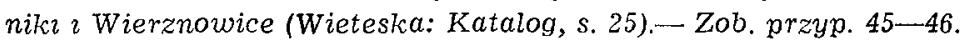

45 Sierzniki, wieś na ter. par. kolegıackıej $w$ Łownczu (Rocznik 1958, s. 307.Waręzak: Słownik, z. 1, s. 89-91).

46 Wierznowice, wieś $w$ par. Zduny $w$ dek. lownckım kolegıaty (Rocznik 1958, s. 310.-Zajączkowscy: Maternaty, cz. II, s. 172).

47 Jan z Rogoźna, nie wiadomo z którego, zm. po r. 1462, posesor szósteł kanonii fund. dzies. Stary Łowicz (Wieteska: Katalog, s. 25).

48 Mikolaj Chmiel posesor šódmej kanonii fund. polowy dzies. Zlaków Duzy (Wieteska: Katalog, s. 25). - Por. przyp. 50.

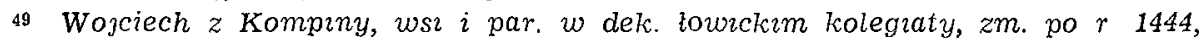
posesor ósmej kanonii fund. drugiej połowy džes. Złaków Duzy (Wieteska: Katalog, s. 25).-Zob. przyp. 50.

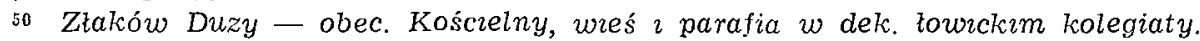

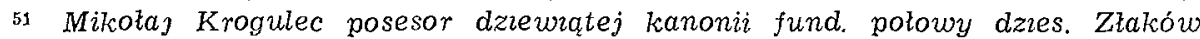
Mały (Wieteska: Katalog, s. 25)--Por. przyp. 53.

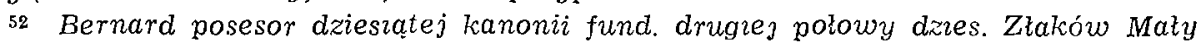
(Wieteska: Katalog, s. 25).-Zob. przyp. 53.

53 Złaków Mały - dziś Borowy albo Nowy, wieś we wspom. par. Złaków Koścrelny $w$ dek. lownckim kolegraty (Rocznik 1958, s. 311).

54 Swıeryz, wieś na ter par. kolegıackıej $w$ Łowıczu (Rocznik 1958, s. 307). 
vicze $^{55}$ una cum decima in villa Boczki ${ }^{56}$, postquam decima ipsa in Boczki ${ }^{1}$ de manibus honorabilis Strzeschkonis Ioannis de Ulanow ${ }^{57}$ clerici diecesis nostre predicte, cui tanquam benemerito, nostro et fratrum nostrorum $\mathrm{Ca}-$ pituli Gneznensis ad hec accedente consensu, per prefatum magistrum Strzeschkonem, tunc rectorem dicte ecclesie S. Marie Lovicensis, de fructibus ipsius ecclesie in provisionem seu sustentacionem, quoad viveret idem Strzeschko Ioannis, vel alıquod beneficium ecclesiasticum sine cura in aliqua ecclesiarum collegiatarum auctoritate ordinaria assecutus foret, est concessa, cedente vel decedente ipso Strzeschkone Ioannis clerico, aut huiusmodi beneficio assecuto, extracta et liberata fuerit, pro fabrica, vino, oleo, luminaribus et aliis necessariis ecclesie assignamus et deputamus per prelatos et canonicos ipsius ecclesie in communi possidendas. Item pro duobus predicatoribus, per Capitulum eiusdem Collegii Lovicensis eligendis, qui manuales et ad nutum capituli eiusdem removibiles existant, decimas in Minori Duplice ${ }^{58}$, in Malischicze ${ }^{50}$ et in Golyenska ${ }^{60}$ de excrescenciis vulgariter przymyarky omnium kmethonum duas mensuras siliginis et duas avene, per advocatum de agris suis racione decime solvendas, decimas per agros advocacle in Myedzvyada ${ }^{61}$, in Svyerzisch decem et octo grossos racione decime currentis monete per advocatum de agris suis solvendos; in Clyewkova Volya ${ }^{62}$ unum fertonem per advocatum de agris suis, in Strzelczova Volya ${ }^{63}$ unum fertonem per advocatum de agris suls, in Chonsna ${ }^{64}$ decem et octo grossos per advocatum racione decime in moneta cur-

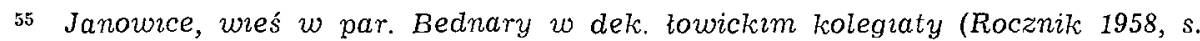
299.- Warężak: Slownik, z. 1, s. 30-34).

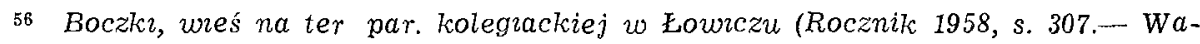
ręzak: Stownik, z. 1, s. 57--58).

57 Strzeszko s. Jana z Utanowa w par. Kłecko. Ks. Korytkowski (Liber beneficiorum, t. II, s. 508, przyp. 1 i s. 512, przyp. 2 oraz Pratacı, $t . I V$, s. 26) miesza go ze

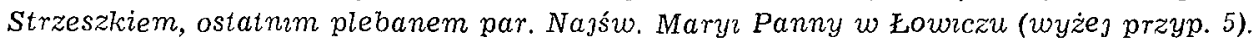

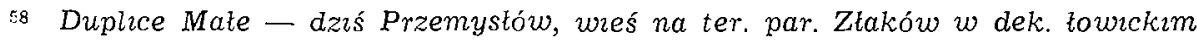
kolegıaty (Rocznik 1958, s. 311.-Waręzak: Słownik, z. 1, s. 88-89).

59 Małszyce, wieś w par. kolegıackiej w Łowıczu (Rocznik 1958, s. 307.-Waręzak: Stownik, z. 1, s. 242-244).

co Goleńsko, wneś na ter. par. kolegiackiej w Łowiczu (Rocznik 1958, s. $307-$ Waręzak: Stownik, z. 1, s. 105-107).

61 Niedźwiada, wreś w par. kolegrackies $w$ Eowrczu (Rocznik 1958, s. 307.-Waręzak: Stownik, z. 2, s. 25-29).

62 Klewków, wieś na ter. par. kolegiackie\} $w$ Łowıczu (Rocznik 1958, s. 307.Waręzak: Stownik, z. 1, s. 145-146).

o3 Strzelceu, wieś w par. kolegıackıej w Łowıczu (Rocznik 1958, s. 307).

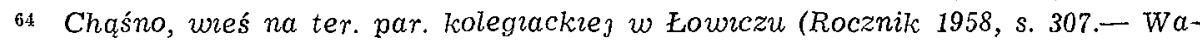
ręzak: Stownik, z. 1, s. $69-71$ ). 
rentı de agris suis; item in Plaskoczyno ${ }^{65}$ 1- de agris advocacre decimam manipularem ${ }^{-1}$, item de agris advocacie Gangolyno ${ }^{66}$ decem et octo grossos latos racione decime, item in Campina 67 de agris advocacie mediam marcam latorum grossorum, item in Schramowo ${ }^{68}$ de agris advocacie decimam manipularem, item in. Lagussow ${ }^{69}$ fertonem currentis monete de agris advocacie, provenientem de ecclesia S. Marie in Lovicz et in Domkovicze 70 decem et octo grossos racione decime monete currentis assignamus et deputamus de fructibus dicte ecclesie S. Marie Lovicensis, ab aliis proventibus eiusdem separando. Qu predicatores singulis diebus ferılibus, alternatıs vicibus, missas pro populo laborioso maturas seu matutinas circa ortum solis legant et confessiones audiant, in Quadragesima vero et Adventu Chr1sti $^{\mathrm{k}}$ tam canonici, quam predicatores audire confessiones fidelium, completis horis, sint adsíricti. Item volumus et, de dictorum fratrum nostrorum Capituli Gneznensis consilio statuimus et assensu, quod canonici $1-$ predicti curam ${ }^{-1}$ gerant animarum, quibus eandem committımus, cum ${ }^{1}$ sacramentis infirmos ordinarie septimanatim, iuxta quod necesse fuerit, procurantes et alia sacramenta Christifidelibus ${ }^{\mathrm{m}}$ ministrantes. Pro quorum canonicorum communitate et decenciori sustentacione missalia in Campina necnon prata in paludibus vocatis Ribno ${ }^{71}$ penes Blandow ${ }^{72}$, prout els ab aliis pratis nostris et kmethonum nostrorum emensurabuntur pro pabulacione equorum, in quibus canonici ad infirmos ordinarie equitabunt, conferimus de voluntate et consensu fratrum nostrorum predictorum. Colendam vero de omnibus villis parochie Lovicensis non solventibus decimas manipulares vel maldratas per unum corum avene de quolibet hospite seu kmethone; colendam autem in opido Lovicz arbitrariam, oblaciones, offertoria, funeralia, omnes questus et obvenciones alias iure parochiali prove-

Kwiat. J-J dwukrotne $w$ LB $\quad \mathrm{k}$ brak $w$ kop. 1, $u$ Kwiat. ${ }^{1-1}$ praedicaturam Kwiat. I tamen $L B \quad \mathrm{~m}$ christifidelium Kwiat. $\mathrm{n}$ et kop. 1, Kwiat.

65 Płaskocın, wieś $w$ par Kompina w dek. towıckim kolegıaty (Rocznik 1958, s. 304.-Waręzak: Stownik, z. 2, s. 52-54).

66 Gagolin, wieś na ter par. Kompına $w$ dek. lownckım kolegiaty (Rocznik 1958, s. 304.-Warezzak: Slownik, z. 1, s. 95-97).

${ }^{67}$ Komplina, wieś z parafia $w$ dek. townckim kolegıaty.

68 Sromów, wieś w par. Kompına w dek. towickım kolegraty (Rocznik 1958, s. 304).

69 Łaguszew, wieś na ter. par kolegiackıej w Łowıczu (Rocznit 1958, s. 307.Waręzak: Siownik, z. 1, s. 180-182).

io Dqubkownce, wieś $w$ par. Ducha Siw. w Łowıczu (Rocznik 1958, s. 316.-Waręzak. Slownik, z. 1, s. 79-82).

71 Rybne, mokradła potozone między wsıamı Błędów na ter par. kolegiackıej $w$ Lowiczu a Wicie w par. Kocıerzew w dek. lowickim kolegiaty (Rocznik 1958, s. 303, 307 - Waręzak: Słownik, z. 2, s. 77).

72 Btędów, wieś na ter par kolegrackıej $w$ Łowiczu (Rocznik 1958, s, 307.-Waręzik: Stownik, z. 1, s. 43-46). 
nientes et mediam sexagenam grossorum per consules pro tempore opıdi Lovicz solvendam ad festum s. Martini ${ }^{73}$ pro communi prelatorum et canonicorum cum rectore scole equaliter dividendos deputamus. Concedimus eciam ${ }^{\mathrm{n}}$, de eorundem fratrum nostrorum consensu, dictis prelatis et canonicis Lovicensibus, quod quilibet eorum cum minoribus retibus, vulg: "iter $\mathrm{v}$ a $t h \mathrm{i}^{\circ}$, piscari possit absque navibus pro eorum prandiis in fluvio Bzura, incipiendo a domo prepositı usque ad granıcies ville nostre inferius proximioris Minoris Zabostovo appellate. Item considerato, quod annone maldratarum, que racione decime manpularis de agris ville Zabostovo Maroris rectorı ecclesie Lovicensis predicte solvebantur, non sine gravi difficultate exigi poterant per censuras ecclesiasticas et penas alias ab agricultoribus ville eiusdem, et quod villa ipsa propterea et sepius in parte desolabatur, consulcius ${ }^{p}$ circa id providere cupientes ${ }^{\mathrm{g}}$, de dictorum fratrum nostrolum consensu, maldratas ipsas in decimam manipularem reduximus et convertimus ${ }^{\mathrm{r}}$, inantea de agris ville eiusdem tempore messium et in campis more patrie per agricultores reddendam loco dictarum maldratarum, et decimam ipsam in Zabostovo Maiori pro rectore scole, quem prepositus ecclesie, ut premissum est, instituat, addentes ibidem de tribus mansis mense nostre decimam ipsi rectori scole; qui pro tempore fuerit magister in artibus aut baccalarius ${ }^{\mathrm{s}}$, aut in eorum defectu vir sufficiens, temporibus perpetuis et in evum assignamus. Item, tam de dictorum fratrum nostrorum Capituli Gneznensis, quam eciam eorundem prelatorum et canonicorum Collegii Lovicensis assensu, decimam eiusdem ecclesie S. Marie in Minori Zabostovo hospitali infirmorum et eius preposito ac ipsis infirmis apud S. Ioannem ${ }^{74}$ adscribinus, annectimus et incorporamus. Qui prepositus curam gerat eorundem infirmorum tam in confessionibus audiendis et sacramentis ecclesiasticis ministrandis, quam necessitatibus ad eorum victum procurandis ${ }^{t}$. Teneaturque ipse prepositus superpelliceatus ${ }^{u}$ et in dalmucio griseo vario $^{v}$, expletis divinis apud $\mathrm{S}$. Ioannem in mane, interesse processionibus diebus dominicis et sollemnibus apud Ecclesiam Collegiatam S. Marie predictam ad laudem Dei Omnipotentis et eiusdem Genitricis Marie et honorem. Quociescunque autem ipsa prepositura hospitalis predicti vacaverit per cessum vel decessum prepositi seu quovis alio modo, consules et communitas eiusdem nostre Lovicensis civitatis eligent sacerdotem idoneum et discretum et presentabunt per nos et successores nostros archiepiscopos instituendum, quod ipsis concedimus ex gracia speciali, ut eo favorabiliores

- rathi Kwrat. p consulendo Kwrat. q cupiendo Kwrat. $\quad r$ commutavimus $L B$ s bacalaureus $L B$ t procurandum Kwiat. u superpellicatus Kwiat. $\quad \mathrm{g}$ griscovario kop. 1, Kwiat, criscovario kop. 2 w-w varigriscis kop.

73 Sw. Marcin biskup $z$ Tours w Galii, zm. w r. 397. Sweęto 11 listopada.

${ }^{74}$ Prepozytura szpıt. św. Jana Chrzc. w İowiczu (Oczykowskı: Przechadzka, s. 116).- O poczattkach tego kościoła zob. nr 2, przyp. 20. 
eisdem infirmis decumbentibus in largicione eleemosynarum et in exhibicione aliorum operum pietatis se exhibeant et existant. Nec ipsi preposito liceat aliud beneficium obtinere simul cum dicta prepositura, ne detur sibi occasio evagandi ab ispo hospitali, circa quod tenebitur curam gerere infirmorum eorundem et residenciam facere personalem. Item areas olim plebani et Nicolai Gosthkonis opidani Lovicensis ${ }^{75}$ pro domibus et curiis prelatorum et canonicorum construendis damus et assignamus inter ipsos dividendas. Item lapidem cere pro lumine ad fontem in festo Pasche per consules solvendum assignamus eidem ecclesie collegiate. Preterea quia SS. Patrum decrevit auctoritas, ordines in Ecclesia pro gradibus dignitatum fore disponendos, ut unus, qui foret prestancior, preemineat pluribus, minores obediant maioribus et superioribus honorificenciam deferant, quapropter statuimus, decernimus et ordinamus, quod prepositus primum in dextera parte chori cum quinque canonicis suprascriptis, uno predicatore et rectore scole, decanus vero similiter primum cum custode et quinque aliis canonicis et uno predicatore stallum in parte chori eiusdem sinistra teneant superpelliciisque et dalmuciis de pellibus ${ }^{\text {w- }}$ varii grisei ${ }^{-w}$, biretis aliisque insignis, ritibus et ceremoniis in capitulo et ecclesiasticis officiis utantur secundum morem metropolitane et aliarum ecclesiarum collegiatarum nostre diecesis et alias tales se exhibeant per opera fructuosa, quod onere nobiscum partito simplices ex data sibi prudencia divinitus exemplis laudabilibus edificent et instruant ad salutem ceterorum ${ }^{x}$. Ut dicti prelati et canonici officia sua, propter que beneficia dantur, ipsa eo perpensius exequantur, volumus quod nullus prelatorum dignitatem cum canonicatu et prebenda insimul in ipsa ecclesia, aut prelatus vel canonicus aliud beneficium extra ecclesiam obtineat seu habere valeat et tenere. Sed singula beneficia singulis personis singilatim commitantur, dictosque prelatos et canonicos ad personalem residenciam circa ipsam ecclesiam et ad horas canonicas decantandas singulis diebus et Beate Marie Virginis missam festivis diebus cantandam obligamus, excessus et negligencias eorum in choro corrigendos preposito ${ }^{\mathrm{y}}$ commitentes $\mathrm{z}$. Statuimus insuper, quod si quis prelatorum et canonicorum eorundem a nobis vel successoribus nostris licencia non petita aut dispensacione non obtenta a dicta ecclesia, cessante infirmitate vel alia iusta causa, quam coram nobis ostendere teneatur, se per tres menses absentare presumpserit, elapsis eisdem mensibus a recessu suo computandis, prelatus diginitate et canonicus canonicatu et prebenda suis eo ipso sit privatus; alius autem ad ipsos dignitatem vel canonicatum et

1, Kwrat., warygryscy kop. $2 \quad \mathrm{x}$ Caeterum $\imath$ od nowego zdania kop. 1-2, Kwiat.

y brak u Kwiat. $\quad$ z committendo Kwiat. aa docto kop. 1-2, Kwiat., actio LB

75 Mikołaj s. Gostka, mieszczanin łownckl. Ks. Korytkowski (Liber beneficiorum, t. II, s. 9 - indeks) mylnie objaśnıa tę postać. 
prebendam, qui residenciam faciat et officia debita impleat, doctus ${ }^{\text {aa }}$ de absencia, institui debeat sine difficultate. Super absencia autem breviori potestatem prepositus habeat, prout qualitas rei exigit, licenciam concedendi ${ }^{\text {ab }}$. At vero preposito extra locum agente, aut in concedendo huiusmodi licenciam difficilem se reddente, seu eciam alicuius rancoris emulacione denegante, extunc ad decanum et in eius absencia ad prelatos 76 et canonicos presentes recurratur, qui iuxta quod negocii requirit necessitas, ipsam licenciam concedant postulanti. Si quis autem constituto sibi die ad ecclesiam redeundi, cessantibus premissis impedimentis, non redierit, extunc post lapsum trium mensium a dicto die numerandorum, suis prelatus dignitate, canonicus canonicatu et prebenda, ut prefertur, eo ipso sit

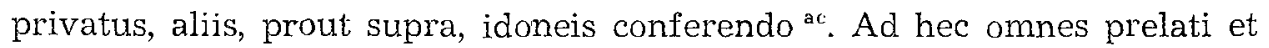
canonici preterqam infirmitate notabili vel alias, ut dictum est, impediti per se ipsos singulis diebus sollemnibus, festrvis, dominicis, profestis et ferialibus horas canonicas, videlicet matutinum, primam, terciam, sextam, nonam et completorium, ad- clerici 77 vero seu scolares scole eiusdem ecclesle in diebus sollemnibus totum matutinum, primam, terciam, vesperas et completorium -ad voce sonora decantent; festivis vero et dominicis matutınum trium leccionum et singulis diebus summam missam et vesperas voce psallere, ut prescriptum est, sint adstricti. Necnon ut premittitur, curam animarum ipsi canonici habeant, confessiones audiant et alia sacramenta parochianis per vices suas seu septimanatim administrent. Verum quum ex causis diversis nos frequenter ab ecclesia nostra cogimur absentari et nedum diecesim, sed et provinciam nostras et alia loca remonta pro Reipublice necessitate perlustrare ${ }^{a e}$, quo fit, quod de statu ecclesiarum nobis subiectarum excessibusque et negligenciis clericorum subditorum puniendis presto noticiam habere non valemus; attento af igitur, quod gravibus quamplurimum ${ }^{\mathrm{ag}}$ onusta et plena est dispendiis in spiritualibus et temporalibus prolixa beneficiorum ecclesiasticorum vaccacio, et ne dicta Ecclesia Collegiata Lovicensis ex facto et culpa absencie prescripte aliquorum in ea beneficiorum, eo ipso post lapsum trium mensium privatorum, debitis in tempus longum remaneat destituta serviciis; cupientes ${ }^{\text {a }}$ eciam $^{\text {an }}$ capitaneum seu gubernatorem pro tempore castri et opidi Lovicz bonorumque Districtus Lovicensis ${ }^{78}$, ad Ecclesiam nostram Gneznensem spectancium,

ab concedendo $L B$ ac conferendis kop. 2, conferenda Kwrat. ad-ad brak u Kwiat. ae personaliter kop. 1, personaliter remaneamus Kwat. af attentoque Kwiat. ag quamplurium Kwrat. ah cupiendo Kwrat. al brak $w$ kop. 2

76 Widać, ze statut erekcyjny wzıęty jest $z$ Gnezna $i$ Łęczycy, bo w Łownczu nue byto juz czwartego pratata.

77 Wnıosek jak $w$ przyp. 76, albowıem $w$ Łowıczu nıe było jeszcze kleryków.

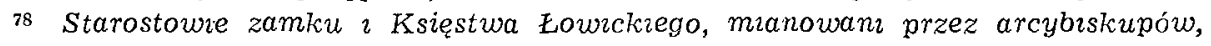

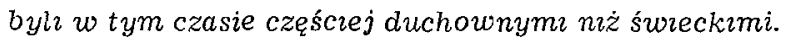


tanta ${ }^{\text {as }}$ erga ipsam ecclesiam perfeccioris fidei integritate et constancie solidare et afficere, quanta ${ }^{\text {ak }}$ ab illa honorıs alcioris impendiis noverit se insignitum: proinde de dictorum fratrum nostrorum Capituli Gneznensis consilio et assensu, eidem capitaneo seu gubernatori pro tempore, ut digna dignis rependamus, ius nominandi et presentandi personas idoneas nobis et successoribus nostris archiepiscopis Gneznensibus ad predictos preposituram, decanatum, custodjam necnon canonicatus et prebendas omnes et singulos Ecclesie Lovicensis, quocies et quocunque modo illos seu illas inantea vaccare contigerit, damus et concedimus temporibus perpetuis duraturum. Postremo quieti et utilitati prefatorum prelatorum et canonicorum ac personarum dicti Collegil Lovicensis providere et materiam frequencium licium et iurgiorum, que inter homines inhabitatores vici seu platee in dicto opido Lovicz per olim ${ }^{\text {al }}$ rectores dicte ecclesie S. Marie in hortis et spacio terre, que ad ipsam ecclesiam perinebant, collocatos ex una et in commune eiusdem opidi mense nostre sepenumero ex altera partibus nascebantur, subducere et submovere volentes, plateam ipsam seu vicum, accedente ad hec consensu dictorum prelatorum et canonicorum Collegii Lovicensis, pro mensa nostra archiepiscopali dicto opido nostro adunavimus et in illius az recompensam per viam commutacions eisdem prelatis et canonicis ac Collegio Lovicensi insulam mense nostre predicte Zavyerzb 79 appellatam, in fluvio Bzura et retro areas prepositi et alior'um prelatorum et canonicorum consistentem, damus perpetuo eisdem prelatis et canonicis ac Collegio et inter eos, succisis arboribus salicum inutilium, dividendam ${ }^{\text {am }}$ ad plantandum pro eis arbores fructiferas et pomeria ac ad serendum an ao- caules, cepe ${ }^{- \text {ao }}$ et alia legumina pro coquina eorundem; donantes eciam eis in commune partem decime manipularis in villa Svyerzisch et decimam de tribus mansis in villa Zabostovo, que ad mensam nostram archiepiscopalem pertinebant. Que omnia sic ordinata, disposita et decreta de certa nostra sciencla et consensu dicti nostri Gneznensis Capituli, presentis scripti patrocinio confirmamus et roboramus perpetuo duratura, firmam habentes fiducian. quod suffragante divini auxilii cooperacione, subsidii non mediocris exinde profectus animarum proveniet et locus ipse Lovicensis reddetur insignior dictaque ecclesia in spiritualibus et temporalibus salubra suscipiet incrementa. In quorum fidem testimonium nostrum et eiusdem Capituli sigilla maiora presentibus sunt appensa. Actum et datum Gnezne in loco capitulari die sabbathı vicesima quinta mensis aprilis anno Domini millesimo quadringentesımo tricesimo tercio presentibus venerabilibus fratribus nostris:

\footnotetext{
as tanto kop. 1-2, Kwiat. ak quanto kop. 1-w2, Kwiat. al brak $w$ LB ał allius Kurat. am dividendarum Kwiat. an ferendum $L B$ ao-ao cunclum semen $K w i c t . \quad$ ap Lyonka Kwrat.
}

70 Wyspa Zawzerzbie na rz. Bzurze. 
Predvogio preposito ${ }^{80}$, Ioanne decano ${ }^{81}$, Ioanne cantore ${ }^{82}$, Andrea scolastico ${ }^{83}$, Ioanne cancelario ${ }^{84}$, Nicolao Gorka ${ }^{85}$, Nicolao Jaroczski ${ }^{86}$, Adam de Bantkow ${ }^{87}$, Nicolao Bronıssy ${ }^{88}$, Benedicto officiali ${ }^{89}$, Ioanne de Rudzicza ${ }^{90}$, Iaroslao de Kankolevo ${ }^{91}$, Paulo Gyziczski ${ }^{92}$, Mathia Chlapowski ${ }^{93}$, Ioanne

so Przedwo $z$ Grad (wsi $w$ par Kamionacz $w$ dek. warciańskım) Gradzki $h$. Łada, kanonik gneźnneński od r. 1404, poznański, kantor wlocławski 1413, kustosz gnieź-

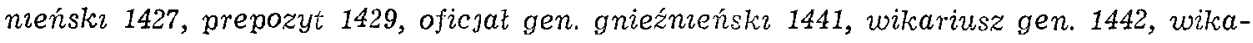
riusz kapitulny 1448, zm. w 1455 (Korytkowskı: Frazacı, t. II, s. 124-129).

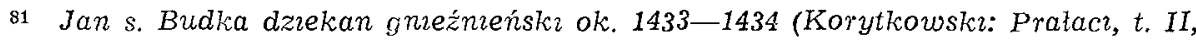
s. 182).

82 Jan $z$ Brzostkowa (wsı kościelnej $w$ dek. jarocıńskim) Brzostkowsk? kantor

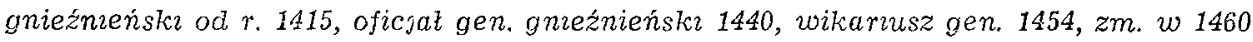
(Korytkowski: Pralaci, t. I, s, 102-103).

83 Andrzej Myszka archidiakon 2 oficjat gen. krakowski od $r$. 1415, scholastyk gnieźnieński 1427, administrator diec. krakowskıej 1434, zm. w 1446 (Eętowskı: Katalog, t. III, s. 354-355.- Korytkowski: Pratace, t. III, s. 61-65).

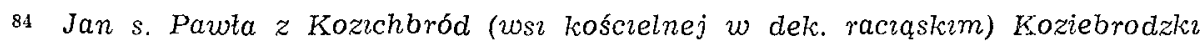
h. Jastrzębrec, kanonik krakouski ok. 1426, kanclerz gnieźnıeńsk? 1428, zm. w 1451 (Eętowski: Katalog, t. III, s. 167.- Korytkowskı: Prataci, t. II, s. 321).

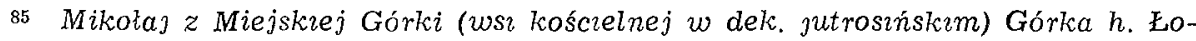

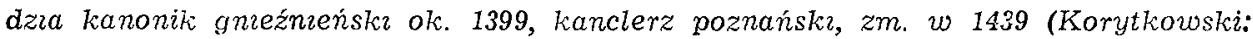
Prałacı, t. II, s. 93-95).

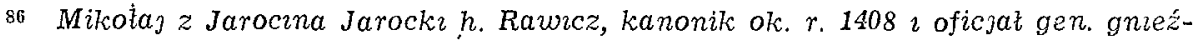

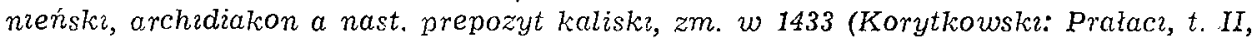
s. 187-188).

87 Adam s. Mikotaja $z$ Będkowa, wsi kościelnej $w$ dek. kurowickim, Spınek $h$. Prus I, mgr prawa kan., kanonik gnieźneński przed r. 1409, kanonik, archiprezbiter

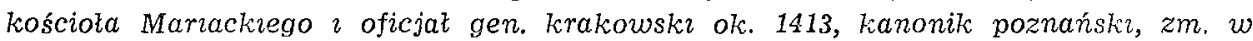
1451 (Eętowsk : Katalog, t. II, s. 22-23.- Korytkowski: Prałaci, t. I, s. 36--38).

88 Mikotaj s. Bronısza kanonik gnıeźnénski w l. 1408-1433 (Korytkowskı: Prataci, t. I, s. 85-86).

89 Benedykt s. Macieja archıdiakon tęczyckı, kanonik gneźnieński $w$ r. 1414, wikariusz i oficjał gen. gneénieński 1418, zm. po 1433 (Korytkowsk?: Prazaci, t. I, s. 42).

90 Jan $z$ Rudzicy, wsi kościelnej $w$ dek. bielskim, h. Dryja, kanonik krakowski, gnieźnieńskı w r 1410, prepozyt par. w Srodzıe Wikp., zm. ok. 1447 (Eętowski: Katalog, t. IV, s. 18.- Korytkowski: Pra?acı, t. III, s. 419-420).

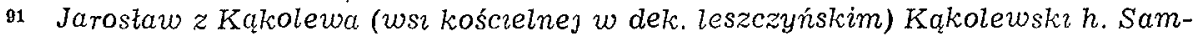
son, kanonik gnieźnieński przed r. 1421, wroclawski, poznański, zm. w 1453 (Korytkowsici: Prakaci, t. II, s. 244-245).

92 Paweł $z$ Gizyc (wsi koścıelnej w dek. sochaczewskim) Gizyckı h. Gozdcwa, bok. sztuk wyzw., kanonik a potem scholastyk plockı, tak samo krakowski, kanonik gnveźneński w r. 1427, poznański 1431, biskup plocki 1439, regent ksıęstwa plockiego 1455-1459, zm. w 1463 (Eętowskr: Katalog, t. II, s. 249-253.-- Korytkowski: Prałaci, t. II, s. 63-66.-Szostkiewrcz: Katalog, s. 66.-PSB (T Stowikowski), t. VIII, s. 23-25).

*3 Maciej Chlapowskı h. Dryja, kanonik gnieźnieńsk $w$ r. 1429, zm. 1435 (Korytkowski: Praìaci, t. I, s. 128-129). 
de Nyevyesch ${ }^{94}$, Sandkone ${ }^{95}$, Adam Svynka ${ }^{\text {ap96 }}$ et Petro Pnyewski ${ }^{97}$, prelatis et canonicis nostre Gneznensis Ecclesie, ad sonum magne campane more solito capitulariter congregatis.

\section{6}

Eowicz, 9 września 1445

Wincenty arcybiskup gnieźnieński i prymas, za zgoda kapituly metrop. gnieźnieńskiej, eryguje z określone części wiejskiego terytorium parafii kolegiackiej w Lowiczu nowa parafię Kompina, uposażajac tamt. kościól (który ufundowal) pt. św. Wojciecha $i$ św. Barbary oraz jego rzadce nadaniami ze stolu arcybiskupiego, parafii macierzystej $i$ in., tudziez zastrzegajac prawo patronatu sobie i swoim następcom.

Or. nie znany.

Wp. 1. $A A G$ : Liber beneficiorum ( $z r$. 1523), rps.

2. Akta arcybpa S. Szembeka pod 29 XII 1713, znısz., $z$ kop. 1 (Regesty zapisek, s. 210.- Librowski: Sumariusz, nr 6).

3. Akta arcybpa Ponıatowskiego pod 9 XI 1793, znısz., $z$ wp. 2 (Regesty zapisek, s. 286).

Kop. 1. Sporz. 5 III 1690 przez kapitulę gnieźnieńska z Liber beneficiorum (wp. 1), nie znana (Librowsk $\imath$ : Sumariusz, nr 6).

2. Wyk. por. 1798 z wp. 2 przez not. Jana Kantego Glowackiego do kopıarıusza Sladeckıego, nie znana (Librowskı: Sumariusz, nr 6).

3. AKL: Kopıarusz Sladeckıego sprzed r. 1810, s. 27-32. Tytul: Erectio ecclesiae parochialis in Kąmpina.

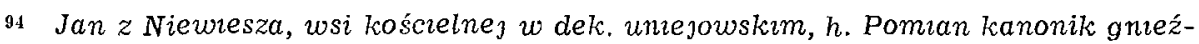
nieński przed 1433, poznański, wikaruusz kapitulny diec. poznańskiej 1437-1439, archidiakon gnieźnieński przed 1438, dziekan wtocławskl, protonotarıusz ap., zm. $w 1454$ (Korytkowski: Prazaci, t. III, s. 96-97).

8s Sędziwoj z Czechla, w par. Kucharki $w$ dek. otobockim, h. Korab, mgr sztuk wyzw., ob. prawa i teologii, prof. Uniw. Krakowskiego; prob. par. Sieradz $w r .1428$, kanonik gnieźnieński przed 1432, prepozyt kolegiaty św. Jerzego w Gnıeźnie, uczestnik Soboru Bazylejskıego, przyjacıel Jana Diugosza, oficjal gen. gnieźnıeński 14491452; „sumienie” kleru, patrota, ne przyjąl od króla bıskupstwa wileńskıego 1453, prepozyt Kanoników Reg. Lat. $w$ Kłodawıe 1458, zm. po 1489 (N. Korbut, 2, s. 104-

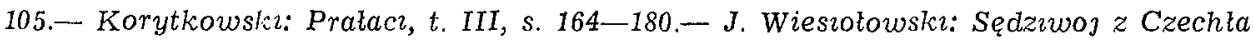
1410-1476, „Stud. źródtozn.”, IX: 1964, s. 75-104.- SPKP (J Wiesiolowski), s. 811.Hajaukiewicz: Historia, s. 607-608).

96 Adam Swinka mgr prawa kan., sekretarz król., kanonik gnieźnieński przed 1413, krakowski, poeta laciński, zm. ok. 1434 (Eętowski: Katalog, t. IV, s. 99.- Korytkowski: Prałaci, t. IV, s. 54-56).

97 Piotr z Pnıew Pniewskı h. Natęcz, kanonik gnieźnieńskı od $r$. 1433, pleban par. Kcynia przed 1443, kantor poznańskı przed 1447, oficıat gen. gnieźnieńskı 14551457 i niedoszly tamt. prepozyt 1455, zm. 1457 (Korytkowski: Prakaci, t. III, s. 227230 ). 
Wyd. Liber beneficiorum, t. II, s. 263-266.

Reg. 1. Wizytacje dóbr, s. XLV, $n r 242$.

2. Librowski: Sumarusz, $n r 6$.

Wzm. Wizytacje dóbr, s. 15-16.

Lit. S. Haln: Wincenty Kot ( $a k$ w przyp. 1) s. 23-24 z blęd. data dzlenna.$J$ Wieteska: Parafia Kompina, monografia historyczna, b.m. 1948.

Uw. 1. Kolejność chron. parafii lowıckich: Najśw. Maryı Panny (kolegıacka) nr 1, 5; Ducha Sw. nr 2; w Komprne nr 6 .

2. Jako utworzona z kolegrackiej - par. Kompına partycypuje $w$ dokumentacji historycznej kapituly towrckiej.

In nomine Domini amen. Ad rei memoriam sempiternam. Nos Vincencius Dei et Apostolice Sedis gracia S. Ecclesie Gneznensis archiepiscopus et primas ${ }^{1}$. Significamus tenore presencium, quibus expedit universis tam presentibus, quam futuris presencium noticiam habituris, quomodo ${ }^{a}$ pastorali sollicitudine sedulaque diligencia super creditum gregem et commissas nobis plebes vigilantes ibi precipua consideracione libenter intendimus, ubi et cultus divinus, quem sub tempus ${ }^{\mathbf{b}}{ }^{\mathrm{c}-}$ - felicis regiminis nostri ${ }^{-\mathrm{c}}$ per multiplicacionem ecclesiarum propagari cupimus, ampliatur et saluti animarum efficaciter providetur ${ }^{\mathrm{d}}$. Sane experiencia, que est magistra rerum efficax, luculenter cognovimus, sexus utriusque homines in villis mense nostre archiepiscopalis Campina ${ }^{2}$, Zabostow Maior ${ }^{3}$, Plaskoczyno ${ }^{4}$, Sramovo ${ }^{5}$, Gangolyno ${ }^{6}$ et Pathoki ${ }^{7}$ degentes, tum propter nimiam Ecclesie Collegiate S. Marie in Lovicz ${ }^{8}$, cui iure parochiali fuerant ${ }^{c}$ subiecte, distanciam, tum eciam inundacionem aquarum, que sepenumero penes Lovicz.

6. a quod $L B$ b tempore $L B$ c-c felicis nostri regiminis $L B$ a provideatur kop. 2 e fuerunt $L B \quad$ f audiendum $L B \quad$ g-g aditus non patebat

6. 1 Wincenty Kot z Dębna, wsi kościelnej $w$ dek. nowomiejskim, $h$. Doliwa, ok. 1395-1448; bak. Uniw. Krakowskiego w r. 1415, mgr sztuk wyzw. 1417, tamt. wykt.

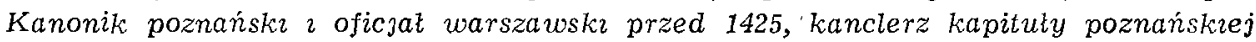
wzgl. biskupa 1425, kandydat na biskupa poznańskiego 1429, jego wikariusz gen. 1429-1430. Kanonik gnieźnıeńskı ok. 1422, kustosz 1432-1436, kantor krakowskı 1434-

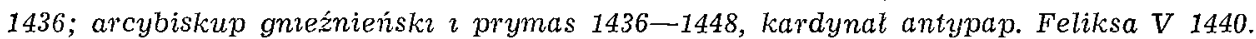
Nauczycıel synów król. 1432-1434, podkanclerzy kor. 1434-1436. Czynny na polu koś-

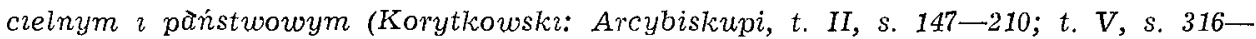

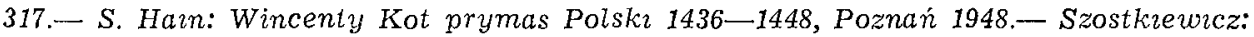
Katalog, s. 101.- PSB (A. Swezawski), t. XIV (1968), s. 450-452).

2 Kompina, wreś 2 par. $w$ dek. towrckim kolegiaty (Rocznik 1958, s. 304-305.Waręzak: Stownik, z. 1, s. 150-154).

3 Zabostów Duzy, wieś na ter. wspom. par. Kompina (Rocznik 1958, s. 304):

4 Płastocin, wieś w tejze par. Kompına (Rocznik 1958, s. 304.-Warężak: Stownik, z. 2, s. 52-54).

5 Sromów, wieś na ter wspom. par. Kompına (Rocznik 1958, s. 304).

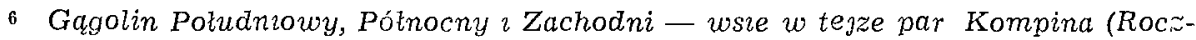
nik 1958, s. 304.-Waręzak: Stownik, z. 1, s. 95-98).

7 Patokı, wieś na ter. wspom. par. Kompına (Rocznik 1958, s. 304). 
contingit, in percepcione ecclesiasticorum sacramentorum et verbi Dei refeccione adeo fuisse neglectos, quod ad consulendum saluti animarum non sine magna difficultate et perıculo corporali Ecclesiam ipsam Collegiatam S. Marie in Lovicz, obstantibus premissis, tempore congruo ad audienda ${ }^{\mathrm{f}}$ divina officıa eis ${ }^{\mathrm{g}-}$ commodus non patebat aditus ${ }^{-\mathrm{g}}$. Ideo tam gravibus et dispendiosis casibus opportune providere cupientes, ne villarum predictarum incole distancia et inundacione aquarum prepediti raro ${ }^{\mathrm{h}}$ vel nunquam ${ }^{\mathrm{i}}$ suorum pastorum monita salubria audientes legisque divine orbati sciencia fierent preda humani generis inmici. Zelo eciam devocionis permoti ecclesiam parochialem in predicta villa Campina in honorem Omnipotentis Dei ${ }^{j}$ eiusque genitricis Marie Illibate ac sub ${ }^{k}$ titulo et ${ }^{1}$ vocabulo s. Adalberti martyris gloriosi ${ }^{9}$ et $b$. Barbare virginis eximie ${ }^{10}$ duximus fundandam, erigendam ${ }^{1}$ fundamusque et erigimus de novo, villasque memoratas, videlicet Campina, Zabostovo Maior, Plaskoczyno, Sramovo, Gangolino et Pathoki a dicta Ecclesia S. Marie Lovicensis et eius parochia removentes et alienantes, predicte ecclesie in Campina nove ereccionis adiungimus et adicimus, adscribimus ${ }^{m-}$ et assignamus ${ }^{-m}$, earum et incolarum in eisdem existencium et futurorum curam et regimen in spıritualibus rectori ipsius " ecclesie in Campina, qui pro tempore fuerit, de cetero committentes decernentesque, ut in ipsa ecclesia in Campina divina officia audiant, sepulturam habeant iuraque parochialia persolvant et tam necessaria, quam voluntaria percipiant ecclesiastica sacramenta. Nos item ${ }^{\circ}$ predictas villas, inhabitatores et incolas earum exnunc ab obediencia et subieccione prelatorum et canonicorum Ecclesie S. Marıe Collegiate Lovicensis prenarrate auctorıtate nostra ordinaria absolvimus et liberamus et eas dicte ecclesie in Campina et elus rectori pro tempore in parochiam subicimus, annectimus et incorporamus per presentes. Et ut rector ${ }^{\mathrm{p}-}$ eiusdem ecclesie ${ }^{-\mathrm{p}}$ in Campina, qui pro tempore fuerit, onera sibi incumbencia ita libere sicut accurate ferre eidemque ecclesie honenstius atque decencius preesse possit et prodesse, de ratihabicione venerabilium fratrum nostrorum Capituli nostri Gneznensis ${ }^{11}$, in dotem dicte ecclesie in Campina et pro sustentacione rectoris et ministri eiusdem bona mense nostre archiepiscopalis et alia inferius desig-

commodus $L B$ h 1 am $L B$ i unquam $L B$ j brak $w$ kop. 2 ls sancti kop. $2 \quad 1$ ac kop. $2 \quad \downarrow$ augendam kop. $2 \quad \mathrm{~m}-\mathrm{m}$ assignamusque kop. 2 $\mathrm{n}$ ejusque kop. 2 a etentim $L B \quad \mathrm{p}-\mathrm{p}$ ecclesiae ejusdem $k o p .2$ q ultronec

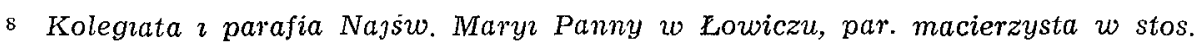
do Kompiny (por nr 1), pierwsza chron. par, towncka (zob. nr 1, uw. 4).

9 Sw. Wojcrech biskup $\imath$ meczennik, zm. $w$ Prusach $w$ r. 997. Swręto 23 kwietnia.

10 Sw. Barbara panna i nęczennica $z$ Nikomedii Bıtyńskıej, zm. w r. 306. Swięto 4 grudnia.

11 Por. $n r$ 2, przyp. 8. 
nata assignamus, videlicet duos mansos agrorum liberos cum tribus sulcis alias za go ni, quorum mansorum quilibet continet in se decem virgas agrorum; iacentque dicti mansi quoad primum campum circa torrentem Przebonya ${ }^{12}$ cum excrescenciis ipsorum ex una et Mathiam Yanowski cmethonem ibidem ${ }^{13}$ in Campina parte ex altera; item ad alterum campum, qui vocatur Przethwrothne ${ }^{14}$, in fine ville Campina sub villa Pathoki et inter Mathiam Yanowskı; item ad tercium campum, in quo in presenciarum ecclesia locatur et edificatur, inter villam Zabostovo et iuxta villam Campina prefatam una cum pratis, ab antıquo ad eosdem mansos pertinentibus. Item duas decimas manipulares in villis, videlicet Unam in Domaradzyno ${ }^{15}$ in Lanciciensi et aliam in Valevycze ${ }^{16}$ in Ravensi districtibus consistentes; et unum corum farine siliginis in molendino Pathoki, quem molendinator dictı molendini diebus sabbathivis singulis septimanı ipsi rectori in Campina dare et de eodem respondere debet; item quatuor hortos desertos, in fine ville Campina iacentes, de quibus quidem hortis advocati tercium denarium, quem pretextu ipsorum advocacie tollebant, volentes participes huiusmodi salubris operis existere, ultronee ${ }^{q}$ remiserunt et a se abdicaverunt, et de eodem coram nobis cesserunt et ${ }^{r}$ eidem renunciaverunt. Preterea dicta ecclesia et eius rector in Campina habebit in ${ }^{\text {s }}$ ipsa villa Campina de quolibet cmethone tres siliginis et tres avene coros racione missalium; et in Zabostovo Maiori, Plaskoczyno, Sramovo, Gangolyno et Pathoki de quolibet cmethone per unum corum avene pretextu colende. Quodque et in predictis villis, videlicet Sramovo et Pathoki post agros et araturas advocatorum decimam manipularem, item in Campina, Zabostovo Maiori, Plaskoczyno et Gangolyno de quolibet manso advocatorum sex grossos latos racione decime rector ecclesie prefate in Campina ${ }^{t-}$ sit perpetue habiturus. Utque ipsa ecclesia et eius rector in Campina ${ }^{-t}$ dictis decimis advocatorum manipularibus et pecuniariis ac frumentis libere ac pacifice uti et gaudere valeat atque possit, prelatos et canonicos Ecclesie Collegiate S. Marie Lovicensis, qui easdem decimas advocatorum et frumenta racione missalium et colende in vim incorporacionis ipsis facte percipiebant, ipsas decimas et frumenta redimendo et ab ipsis eximendo, in recompensam aliss certıs

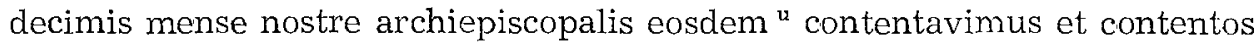

\footnotetext{
$L B \quad \mathrm{r}$ brak $w$ kop. $2 \quad \mathrm{~s}$ (de) $L B \quad$ t-t brak $w$ kop. 2 u eos kop. 2 12 Przebonia, strumień wpadajacy od str, zachodniej (lewej) do rz. Bzury.-Zob. nr 5, przyp. 8.

13 Maciej Janowski, kmieć ze wsi Kompina.

14 Przedwrotne - nazwa pola w Kompine, sasiadujacego ze wsza Patoki.

15 Domaradzyn, wies $w$ par Bratoszewice w dek, strykowskim (Zajaczkowscy: Materlaty, cz. I, s. 71.- Diecezja tódzka, s. 347).

16 Walewice, wieś na ter. par. Bielawy $w$ dek. townckim Sw. Ducha (Rocznitk 1958, s. 313.-Zajaczkowscy: Materiaty, cz. II, s. 238).
} 
fecimus. Item rector ${ }^{v-}$ dicte ecclesie $^{-v}$ poterit locare unam tabernam in suis agris et hortis predictis, ubi maluent. Item piscaturam ${ }^{\text {w }}$ habebit prandendi pisces in fluvio Mssura ${ }^{17}$ tam $^{x}$ in glaciebus, ${ }^{y-}$ quam eciam in ${ }^{-y}$ resolucione glacierum, incipiendo ab hereditate Maiori Zabostovo usque ad limites mense nostre archiepiscopalis, videlicet ville Thyczenogi ${ }^{18}$. Item rector ecclesie in Campina ${ }^{z-}$ pro tempore ${ }^{-z}$ pro edificacione et structura domus plebanalis robora et pro foco ligna in silvis nostris Zyambskye ${ }^{19}$ excidendi habebit liberam facultatem. Que omnia et singula sic, ut premittitur, per nos donata dicte ecclesie in Campina damus, appropriamus, adscribimus, incorporamus presentisque aa scriptı patrocinio annectimus, per upsam et eius rectorem pro tempore existentem possidenda, habenda, tenenda, utifruenda et in usus beneplacitos convertenda temporibus perpetuo duraturis. Etsi prefati advocati, cmethones et molendinator in solvendis decimis, annonis et coro farine fuerint remissi, negligentes vel rebelles, officialis noster Lovicensis ${ }^{20}$, requisitus per rectorem ecclesie prefate, eosdem ${ }^{\text {ab }}$ ad solvendum premissa ecclesiastica censura mediante compellet. Collacionem vero ipsius ecclesie in Campina nobis et successoribus nostris reservamus. In cuius rei testimonium nostrum et capituli nostri predicti sigilla presentibus sunt appensa. Actum et datum in Lovicz feria quinta proxima post festum Nativitatis S. Marie Virginis anno Domıni millesimo quadringentesimo quadragesimo quinto, presentibus ibidem venerabilibus et honorabilibus dominis Thoma de Strzepyno ac sacre theologie professore et decretorum doctore canonico ${ }^{21}$ et Ioanne Furman custode Ecclesie no-

$v-v$ ecclesie dictae kop. $2 \quad$ w piscatoriam $L B \quad x$ tum kop. $2 \quad y-y$ quarum kop. $2 \mathrm{z}^{\mathrm{z} z}$ per tempus kop. 2 aa et praesentis $L B$ ab brak $w$ kop. 2 ac Krzepino kop. 2 ad-ad baccalaureo et decretorum kop. 2.

17 Msura, późnıej Bzura, rzeka.-Por nr 5, przyp. 8.

18 Tyczynog?, weśs w par. Kozłów Szlacheckl w dek. sochaczewskım (Rocznik 1958, s. 438).

19 Ziabskie lasy, przynalezne do ws Ziabki na ter. par. Bolimów w dek. Łowıckim kolegraty (Rocznik 1958, s. 302).

20 Jest to pierwsza chron. wzmanka o oficjale towickim.

21 Tomasz ze Strzępınıa, $w$ par. Granowo $w$ dek. grodziskim, $h$. Prus 1398-1460; bak. Uniw. Krakowskıego w r. 1421, mgr satuk wyzw. 1427, dr prawa kan. i teologii 1431, prof., rektor 1432, 1443, uczestnik Soboru Bazylejskıego 1433-1435. Kanonik gnıénneńsk 1437, kraḱowsłı przed 1446, scholastyk gnieźnıeński 1446, krakowski 1453, kandydat kapituly metrop. na arcybiskupstwo gnieźnieńskie 1453, biskup krakowski 1455. Podkanclerzy kor. 1454-1455. Czynny na polu kościelnym $i$ naukowym (Æętowski: Katalog, t. I, s. 408-420-- Korytkowski: Prałaci, t. IV, s. 27-38- Szostkiewicz: Katalog, 8. 182.- Kurasıowa: Kancelaria, s. 155.- SPKP (M. Matuszewsica), s. 864.-Hajdukzewrcz: Historna, s. 658-659). 
stre Gneznensis ${ }^{22}$ ac Nicolao de Zavada preposito ${ }^{23}$, magistro Mathia de Orlow ad-baccalario in decretis ${ }^{-a d}$, custode ${ }^{24}$, Ioanne Dworski canonico predicte Ecclesie Collegıate Lovicensis ${ }^{25}$ et Nicolao de Kyelkovycze baccalario in decretis, curie nostre cancellario, qui presentes a nobis habuit in commissis ${ }^{26}$ et aliis pluribus testibus circa premissa.

Chruślin, 26 stýcznia 1465

Jan arcybiskup gnieźnieński, prymas i kanclerz Król. Polskiego - na prośbę Mikolaja $z$ Kielkowic bak. prawa kan., prepozyta lowickiego $i$ kanonika lęczyckiego a za zgoda kapituly towickiej - eryguje jako oddzielne beneficjum ufundowany przez uspomnianego $w$ tamt. kolegiacie, $w$ kapticy pod organem $i$ uposażony oraz dedykowany już oltarz ku czci Trójcy Şwrętej tudzreż św. Mikołaja, Marcina, Elżbiety i Jadwigi, określając uprawnienia $\imath$ obowiazki oltarzysty. Fundatorowi przyznaje arcybiskup patronat nad oltaria, który po jego śmierci ma przejść na miejsc. kapitulę.

Or. nie znany.

Kop. 1. AAW: Kopıarıusz Janickiego z r. 1749, s. 35-38. Tytut: Copıa privilegii fundationss Altarıs Sancti Nicolar sub organo in Ecclesia Loviciensi - -

2. AKE: Koplarıusz Sladecksego sprzed r. 1810, s. 61-63, 68-71. Tytut:

1465. Erectio Altaris S. Nicolai.

Wyd. Liber beneficiorum, $t$. II, s. 520-522.

Reg. Librowskı: Sumariusz, nr 16.

Wzm. Liber beneficiorum, t. II, s. 252-253; opis uposażenia oltarii.

Uw. Oltarz ten nazywano później tylko mianem św. Mikolaja.

In nomine Domini amen. Ioannes Dei gracia Sancte Ecclesie Gneznensis archiepiscopus et primas ac Regni Polonie cancellarius ${ }^{1} .{ }^{a-}$ Ad perpe-

22 Jan Furman z Niezamyssla, ws zagınionej $w$ Wielkopolsce, kanonik gnieźneenski $w$ r. 1409, dzıekan tęczyck, archidiakon warszawski 1431, kustosz gneeźnienski 1437, zm. w 1458 (Korytkowski: Pralaci, t. II, s. 31).

23 Mikołaj z Zawady prepozyt lowicki ok. r. 1445 (Wieteska: Katalog, s. 29).

24 Maciej $z$ Orlowa, mgr sztuk wyzw. w r. 1432 i bak. prawa kan. Unıw. Krakowskiego, kustosz lowrcki ok. 1445-1462 (Wieteska: Katalog, s. 29).

25 Jan Dworski kanonik towick ok. r. 1445 (Wieteska: Katalog, s. 29).

26 Mikoła\} $z$ Kiekkowic, na ter. par Giebło $w$ dek. pilickim, bak. prawa kan. Uniw. Krakowskiego, kanclerz kurii arcybpa Kota, kanonik łowrckı ok. 1443, dzzekan 1448, prepozyt przed 1465, tamt. oficjat 1474-1475, kanonik tęczyckı, zm. $w$ 1478 (Haın: Wincenty Kot, jak w przyp. 1, wg indeksu.-Wieteska: Katalog, s. 27-28).

э. ${ }^{a-a}$ Ad rel memoriam sempiternam kop. 2 b suorumque kop. 1-2

\%. 1 Jan Gruszczyński z Gruszczyc i Iwanowic, miejscowości kościelnych $w$ dek. blaszkowskim, h. Poraj ok. 1405-1473. Kanonik w Eger na Węgrzech w r. 1440, 
tuam rei memoriam -a. Immensa benignitas Conditoris homini, quem ad suam formavit similitudinem, primi lapsu parentis suorum ${ }^{b}$ labe criminum $^{c}$ deformato innumera prestat beneficia et adminicula multa parat, quibus expiare commissa suorumque disrumpere vincula delictorum promereri veniam et reconciliari suo valeat Creatori, utriusque hospilitatis opera tanto prestanciora et utiliora ad promerendam salutis graciam stabilivit, quanto per ipsa maiora et accepciora obsequia Patris Iuminum in divini cultus augmento et Dei ministrorum multiplicacione impenduntur. Sane in nostra constitutus presencia venerabilis dominus Nicolaus de Kyelkovicze baccalarius in decretis, prepositus Lovicensis et canonicus Lanciciensis Colleg1atarum Sancte Marie Ecclesiarum ${ }^{2}$ nostre diocesis, hac permotus ${ }^{\star}$ salubrique ductus devocione, cupiens pro rebus transitoriis et caducis bonisque mundanis, que fluunt et refluunt nequeuntque subsistere una sorte, Christl graciam et perhennis corone gloriam promereri et indeficientes divicias deliciasque adipisci. Et ob id nobis supplicavit, quatenus in dicta Ecclesia Collegiata Sancte Marie Lovicensi et in capella sub organo ${ }^{3}$ altare iam constructum et dedicatum ad honorem Sanctissime Trinitatis ac sanctorum Nicolai ${ }^{4}$ et Martini ${ }^{5}$ pontificum et confessorum necnon Elısabeth ${ }^{6}$ et Hedvigis ${ }^{7}$ electarum pro altarista sive ministro per eum certis censibus et redditibus annuis, videlicet octo marcis cum sedecim grossis in Lassycznyki, villa nobilis Sassyny ${ }^{8}$ nostre Diocesis Gneznensis, mediorum grossorum monete et numeri Polonicalis per ipsum de bonis

- communi kop. I a promotus $L B$ e pecuniaria kop. 1 f-f pro altarista pleban w Sieradzu 1442, kustosz krakowskl, kanonik gnieźnıénski 1444, poznański 1445, spór o diec. wtoctawska z Mikołajem Lasockim 1449, biskup włocławski 1451-1463, spór o diec. krakowska $z$ Jakubem $z$ Sienna 1463, biskup krakowski 1463, arcybiskup gneeźnıénski i prymas 1464-1473. Pisarz kancelarii król. 1430, sekretarz 1450-1454, kanclerz państwa 1455-1469, członek rady król. Czynny na polu koścrelnym, a zwzaszcza państwowym (Eętowski: Katalog, t. II, s. 1-25.- Korytkowski: Arcybiskupi, t. II, s. 329-387; t. V, s. 301-302.- Fijalek: Ustalenie, s. 63.- Szostkiewrcz: Katalog, s. 71-72.- PSB (K. Malınowski), t. IX (1960-1961), s. 55-57.- Kurasıowa: Kancelaria, s. 125, nr 51).

2 Mikolaj z Kielkowic - zob. nr 6, przyp. 26.

3 Kaplica „pod organem” czyli pod chórem śpıewaków jest pierwsza chron. kaplıca w kolegracie zowrckıe pośwradczona przez zródta hıst.

4 Sw. Mikołaj bıskup Myry w Azji Mniejszej, zw. Cudotwórca. zm. w l. 345352. Swięto 6 grudnia.

s $S w$. Marcin - zob. nr 5, przyp. 73.

6 Sw. Elżbieta księzna Turyngí, zm. w r. 1231. Swięto 19 listopada.

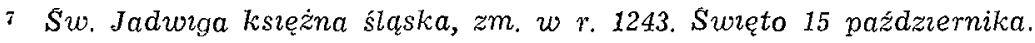

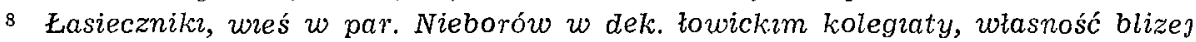

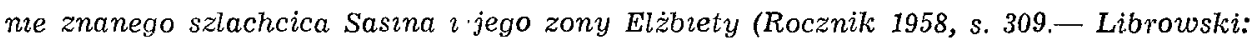
Sumariusz, nr 16, insert). 
et facultatibus suis luste conquisitis, sub condicione reempcionis emptis et pro certa summa pecuniarum ${ }^{\circ}$ comparatis sufficienter dotatum, erigere et fundare privilegiumque preclare principis domine Anne, ducisse Mazovie ${ }^{9}$, in pergameno scriptum, eius vero sigillo rotunde figure, intus de rubea, ab extra vero de communi ceris, in cordula sericea, subappensum sigillatum, huiusmodi census empcronem, resignacionem et solucionem contmens, et quod ipse Nicolaus prepositus in evidencia prefate dotacionis coram nobis exhibutt ratificare et approbare, adiectis nonnullis oneribus i- per altaristam ${ }^{-\mathrm{f}}$ pro tempore exıstentem ${ }^{\mathrm{g}}$ ferendis, dignaremur.

W koprarzu Sladeckiego (s. 63-68) następuje nie publikowany dokument (insert), wyst. (Sochaczew, 13 grudnia 1463) przez ks. mazowiecka Anne, zezwalajacy wspom. Sasinowi i jego żonie Elżbiecie na obciażenie swoich dóbr Lasieczniki kapıtałem Mikoiaja z Kielkowic w wysokości 140 flor. węg. i 30 kóp gr pol. za wyplacany temuż roczny czynsz 61/2 kóp oraz $10 \mathrm{gr}$, stanowiq̨cy zasadnıcza część uposażenia wiad. oltarzysty.-Por. Librowski: Sumariusz, nr 16 (insert).

Nos igitur Ioannes archiepiscopus et cancellarius memoratus peticionibus dicti Nicolai prepositi Lovicensis, tanquam iustıs benigniter inclinati, volentes Ecclesiam Collegiatam Sancte Marie Lovicensem ${ }^{\mathrm{h}}$ predictam amplioribus insignire honoribus dictique Nicolai prepositı piam et devotam in perfectam ', ut ceteri elus exemplo ad similia pietatis opera assurgant propensius, quanto uberioribus huiusmodi prerogativis ipsius devotam intencionem per nos roboratam, predictum altare Sanctissime Trinitatis ac sanctorum Nicolai et Martini pontificum et confessorum necnon Elisabeth et Hedvigis electarum in predicta capella sub organo situatum, de consensu honorabilium prelatorum et canonicorum Ecclesie predicte Lovicensis ${ }^{10}$, sicut premissum est, octo marcis et sedecem ${ }^{3}$ grossis census annui dotatum, auctoritate ordinaria et de certa nostra sciencia in nomine Domini erigimus, creamus et fundamus per altaristam pro tempore existentem regendum et gubernandum, censumque predictum octo marcarum cum sedecem ${ }^{3}$ grossis mediorum grossorum percipiendum et levandum et in usus beneplacitos convertendum. Prescriptum quoque privilegium et singula in eo contenta recipimus, admittimus; ratificamus, gratificamus, approbamus et in robur perpetue firmitatis confirmamus, censumque predictum et alia infrascripta dicto altari et altarıste incorporamus per presentes. Et quia altare huiusmodi principali intencione pro laude Summi Dei et eius Geni-

\footnotetext{
$L B \quad$ g existente $L B \quad$ h Loviciensis $L B \quad$ I praescriptam $L B \quad$ j sedecim

9 Anna wdowa po Wtadysiawie I ks. mazowieckim, zm. w r. 1482.

10 Zgoda kapıtuly kolegıackıj na niektóre posunięcia ordynarıusza dotyczyła

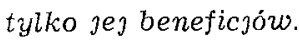


tricis Intemerate saluteque animarum dotatum est et institutum, unde volumus et ordinamus sicque omnibus dicti altaris altaristis pro tempore existentibus sub excommunicacionis pena precipimus et mandamus, quatenus anno quolibet et in singulis septimanis tres missas, videlicet secunda pro defunctis et quarta feriis de sancto Nicolao pontifice glorioso et sabbato de Beatıssima Virgine Marıa Domina Nostra, agendo in eis pro dicto Nicolao preposito et elus parentibus dignam memoriam, per se vel per alium legat et peragat sine intermissione. Quodque idem altarista dicti altaris pro tempore exıstens Cursum de Beata Virgine cum viccaris et aliis ${ }^{\mathrm{k}}$ mansionariis dicte Ecclesie Lovicensis decantare tenebitur. Racione cuius decantacionis, singulis diebus facte, de censibus pro mansionariis et viccariis emptis singulis annis pro salario tres cum media marcas mediorum grossorum monete et numeri Polonicalis tollet recipiet et habebit. Necnon ortum post pontem inter ortos domini decani et custodis consistentem, per ipsum Nicolaum prepositum a Nicolao Reschka ${ }^{11}$ per commutacionem partis ortus circa allodium ipsius Nicolai et per ipsum prepositum receptum, ac aream cum domo iuxta domum domini Petri de Pyąntek canonici Lovicensis ${ }^{12}$, in cemiterio situatam, pro incolatu et habitacione habebit, tenebit et de consensu prelatorum et canonicorum Ecclesie predicte Lovicensis possidebit. Tenebiturque idem altarısta in ipsa Ecclesia Lovicensi superpelliciatus $^{1}$ infra divina et cantus horarum canonicarum incedere et processionibus interesse. Ac censum altaris predictum, si aliquando reemptus fuert, pro pecuniis principalibus sive capitalibus equalem vel similem reemere et comparare, cum sciencia Capituli Ecclesie Lovicensis predictr, habebit, in quo eorum conscienciam oneramus. Quem censum superius emptum et descriptum ac dicto altari et altariste per nos incorporatum et inantea comparandum ac ortum et aream sive domum predictam deinceps ecclesiastıce subicimus libertati. Cuius quidem altarıs ius patronatus et presentandi ipse dominus Nicolaus de Kyelkovicze prepositus Lovicensis predictus vita sibi comite habebit et possidebit ac personas idoneas, quas maluerit, tempore vacacionis nobis et successoribus nostris, dominis archiepiscopis pro tempore existentibus, ad dictum altare instituendos presentabit. Ipso vero Nicolao preposito vita functo, honorabiles prelatos et canonicos totumque Capitulum Ecclesie Sancte Marie Lovicensis predicte, de voluntate eiusdem Nicolai prepositi, dicti altaris decernimus esse veros et unicos patronos et collatores, qui tempore vacationis nonnisi unum ex viccariis Ecclesie Lovicensis, seniorem vocacione, ad dictum altare domino

\footnotetext{
kop. 2, LB k brak w kop. $1 \quad 1$ superpiliciatus kop. 1, superpelliccatus kop. 2

$i$ nostri kop. $2 \quad \mathrm{~m}$ ad kop. 2 n brak w kop. 2.

11 Mikolaj Reszka, blizej nie znany mieszczanin łowrckı.

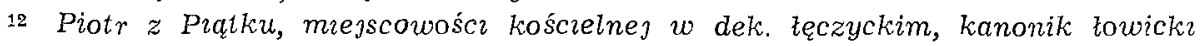
ok. 1459-1465 (Wieteska: Katalog, s. 30).
} 
loci ordinario presentabunt instituendum temporibus perpetue duraturis. Ad quod quidem altare Sanctissime Trinitatis ac sanctorum Nicolai et Martini confessorum, sic per nos errectum et fundatum, discretum Nicolaum Andree de Pylcza clericum Cracoviensis Diocesis ${ }^{13}$, nobis per prefatum dominum Nicolaum prepositum vive vocis oraculo presentatum, per manus nostre ${ }^{i}$ capiti suo imposicionem instituimus et investivimus ac investimus, administracionem spiritualium et temporalium eiusdem altaris sibi committendo per presentes. Mandamusque viccariis Ecclesie Lovicensis predicte, quatenus Nicolao predicto altariste prefati altaris possessionem realem omnium iurium, redituum et pertinenciarum ac domus et aree assignent. In cuius rei testimonium nostrum et dicti Capituli Lovicensis sigilla presentibus sunt appensa. Actum et datum in villa Chroslyno ${ }^{14}$ et in Curia nostra Archiepiscopali ${ }^{15}$ die sabbati vicesima sexta mensis Ianuarii anno Domini millesimo quadringentesimo sexagesimo quinto, presentibus ibidem venerabilibus et honorabilibus dominis Iacobo Iablowski canonico Poznaniensi ${ }^{16}$, Stanisalao Mylycy de Chroslyno ${ }^{17}$ et Martino in Czarnoczyn ${ }^{18}$ ecclesiarum parochialium rectoribus, et nobili Alberto Pąngowski ${ }^{19}$ et aliis pluribus testibus circa ${ }^{\mathrm{m}}$ premissa etc. ${ }^{\mathrm{n}}$.

\section{8}

Łowicz, 9 września 1465

Jan arcybiskup gnieźnieñski, prymas i kanclerz Król. Polskiego eryguje $w$ kolegiacie lowickiej oltarz, a przy nim oltarie ku czci Boga Wszechmogacego i Najśw. Maryi Panny a pw. świętych Jana Chrzciciela $i$ Jana Ewangelisty, Jakuba Apostoka $i$ wszystkich apostolów, Wojciecha, Stanislawa, Marcina, Aleksego, Agnieszki, Doroty, Katarzyny, Barbary i Jedenastu Dziewic, pochodzacy $z$ fundacji dziekana lowickiego $i$ kanonika leeczyckiego Jakuba z Kowalewic oraz własnej - z dóbr arcybiskupstwa (na co otrzymał zgodę kapituly gnieźnieńskiej). Arcybiskup określa uprawnienia $i$ obowiazki oltarzysty, przyznajac wspólfundatorowi prawo patronatu, które po jego śmierci przejdzie na kapitulę lowicka.

13 Mikolaj z miosta Pilicy, s, Andrzeja, kaplan, przyp. krewny prepozyta towickiego Mikołaja z Kiełkownc.

11 Chruślin, wieś koścıelna w dek. lowickım Sw. Ducha (Rocznik 1958, s. 313314.- Warezak: Stownik, z. 1, s. 73-76).

15 Jedna $z$ rezydencji arcybiskupich, w której aktualnie urzędowata ruchoma kancelarza arcybpa Gruszczyńskiego.

18 Jakub Jabłowski kanonik poznańskı.

17 Stanısıaw s. Milika pleban w Chruślinıe.

18 Marcin pleban z Czarnocina w dek. kurownckim.

19 Wojciech Pagowski szlachcıc, pewnie dworzanın arcybpa Gruszczyńskiego. 
Or. nie znany.

Kop. (współcz.), AAG, B5: Kopıarıusz z lat 1459-1585, k. 114-114v. Tytut: Ereccio altaris in Lowicz.

Wzm. 1. Dokument z r. 1492 - nızej nr 11.- Librowski: Sumarusz, nr 26. 2. Liber beneficiorum, t. II, s. 252 .

3. Korytkowskı: Arcybrskupı, t. II, s. $360-z$ blęd. nazwa wsi Plyćwia.

4. Wieteska: Katalog, s. 29-30 - z niedokt. informacja, że dzlekan Jakub byt wytacznym fundatorem ottarza.

In nomine Domini amen. Ad perpetuam rei memoriam. Immensa benignitas homini, quem ad suam formavit similitudinem, primi lapsu parentis suorumque labe criminum deformato innumera prestat beneficia et adminicula multa parat, quibus expiare commissa suorum dirumpere vincula delictorum promereri veniam et reconciliari suo ${ }^{2}$ Creatori. Apostolus quoque Doctor gencium ${ }^{1}$ suis verbis denunciat, ut eternorum intuitu seminetur in terrıs, quod cum multiplicato fructu potest recolligi in celis. Proinde nos Iohannes Dei gracia Sancte Ecclesie Gneznesis archiepiscopus et primas $\left[\mathrm{ac}^{\mathrm{b}}{ }^{\mathrm{C}}\right.$ Regni Polonie cancellarius ${ }^{2}$ significamus tenore presencium, quibus expedit universis, quod cum venerabilis dominus Iacobus de Cowalevicze decanus Loviciensis et canoninus Unyeoviensis Collegiatarum Sancte Marie Ecclesiarum ${ }^{3}$, frater noster in Christo dilectus, habeat devocionem altare in dicta Ecclesıa Loviciensi instruere, fundare et dotare certis proventibus et redditibus inferius descriptis in augmentum cultus divini et in remedium salutis sue et progenitorum ac benefactorum suorum; nos habito respectu ad merita et servicia ipsius Iacobi decani per eum a temporibus retroactis predecessoribus nostris ac ecclesie nostre exhibita. horum intuitu ac eciam contemplacione devocionis sive et ipsius cultus divini, ad quem in dicta Ecclesia Loviciensi nove ${ }^{c}$ plantacionis augendum ferimur singulari zelo et affeccione, decimam nostram manipularem cuiuslibet grani et seminis ac canapi in villa Plyczwya ${ }^{4}$ mense nostre archiepiscopalis in districtu Loviciensi ${ }^{5}$ et tenuta Squirnyeviensi ${ }^{6}$ consistente, sub rathihabicione venerabilium fratrum nostrorum dominorum prelatorum et canonicorum Capi-

\footnotetext{
8. a $w$ kop. następuje przekreślone Conditorı b opuszczone wkop. c c nowe kop. a Ewangeliste kop. e lekcja pravdopodobna.

8. 1 Sw. Pawel apostol $\imath$ męczennik, ścęty za wrarę $w$ Rzymie $w$ r. 67 Swręto 29 czerivea.

2 Jan Gruszczyńskı - zob. nr 7, przyp. 1 .

3 Jakub z Kowalewic, wsi $w$ par. Parzęczew dek. ozorkowskiego, bak. prawa kan., dziekan towick ok. r. 1456, kanonik uniejowsk ok. 1462, pleban w Makowie

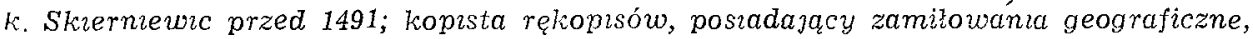
zm. w 1492 (Wieteska: Kataloz, s. 29-30.- Hajdukiewicz: Histora, s. 255).

4 Plyćwia, wieś na ter par. Godzıanów $w$ dek. skiernıewıckım (Rocznik 1958, s. 422.- Waręzak: Stounik, z. 2, s. 55-57).

5 Dystrykt, a wiaścnue kasztelanza towncka.

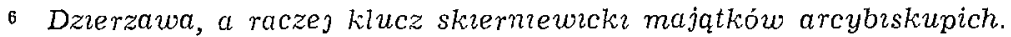


tuli Ecclesie Gneznensis ${ }^{7}$, pro huiusmodi altaris dotacione damus, donavimus, appropriamus et incorporamus graciose per presentes per altaristam dicti altaris pro tempore existentem habendam, tenendam, possidendam, tollendam et in usus voluntarios convertendam temporibus perpetuis et in evum. Quod quidem altare ad honorem Omnipotentis Dei et beatissime Virginis Marie necnon beatissimorum Iohannis Baptiste ${ }^{8}$ et Iohannis Evangeliste ${ }^{\mathrm{d} 9}$ ac Iacobi ${ }^{10}$ et omnium apostolorum, Adalberti ${ }^{11}$ et Stanislai ${ }^{12}$ pontificum, Martini ${ }^{13}$, Allexii ${ }^{14}$ confessorum necnon Agnetis ${ }^{15}$, Dorothee ${ }^{16}$, Katherine ${ }^{17}$, Barbare ${ }^{18}$ et Undecim Milium Virginum ${ }^{19}$ in Dei nomine erigimus et fundamus. Dictamque decimam manipularem et canapi in Plyczwya una cum area pro domo seu habitacione predicti altaris ministri sive altariste, circa aream altaris per dominum prepositum Loviciensem ${ }^{20}$ fundatı sitam; necnon orto ac eciam area circa pontem dicte civitatis Loviciensis, eundo versus Sochaczow ${ }^{21}$, per ipsum dominum Iacobum decanum emptos et comparatos ac ab omnibus solucionibus, censibus et quibusvis exaccionibus nostris et civitatis nostre Loviciensis predicte liberos et exemptos incorporamus et invisceramus tenore presencium mediante. Ut autem ipse Iacobus decanus speratos exinde fructus consequi mereatur, statuimus et ordinamus, quod altarista eiusdem altaris pro tempore existens singulis septimanis tres missas: unam [k. 114v] videlicet secunda pro defunctis, aliam quarta feriis pro peccatis ac die sabbati de gloriosa Virgme Maria

7 Por. nr 2, przyp. 8.

- Sw. Jan Chrzciciel, zwrastun Chrystusa Pana, ścręty na rozkaz kr. Heroda ok. r. 29. Swręto urodzenia 24 czerwca, śctęcıa 29 sierpnua.

$\checkmark$ Sw. Jan apostot $\imath$ ewangelista s. Zebedeusza, zm. ok, $r 100 w$ Efezre. Swieto 27 grudnza.

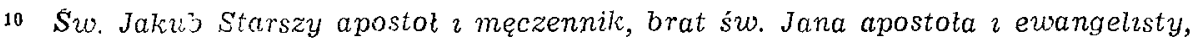
ścęty ok. $r 44$ na polecenie kr. Heroda Agryppy. Swięto 25 lıpca.

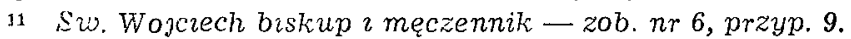

12 $S w$. Stanıstaw biskup krakowskı i męczennik, zm. w r. 1079. Swręto \& maja.

13 Sw. Marcin brskup - zob. nr 5, przyp. 73.

14 Sw. Aleksy wyznawca, zm. w Rzymie w r. 417. Swręto 17 lipca.

15 Sv. Agnieszka panna $\imath$ męczennica, zm. w Rzymie ok. $r$. 304-305. Suręto 21 styczria.

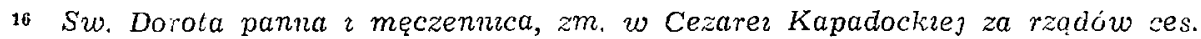
Dioklecjana (284-305). Swęto 6 lutego.

17 Sw. Katarzyna panna ı męczennca - zob. nr 2, przyp. 4.

18 Sw. Barbara panna i męczennica - zob. nr 6, przyp. 10.

1911000 Dzıewrc i Męczennic (legenda); pewnie tylko 11 Towarzyszek św. Urszuli, zm. k. Kolonii na prze?. IV/V w. Swięto 21 paźdzzernika.

20 Miicozas z Kiekkowic - zob. nr 6, przyp. 26.

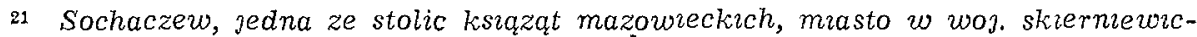
$k \imath m$. 
advocata nostra precıpua dicto Iacobo decano in humanis agente, post mortem vero ipsius predictis secundis et quartis feriis pro defunctis, specialem collectam pro defuncto sacerdote imponendo, et terciam predicto die sabbati de beata Virgine Maria, per se vel alium circa altare predictum, in dextra parte intrando chorum istum ${ }^{22}$, legere et explere teneatur. Quod quidem altare non alteri, nisi uni de gremio vicariorum dicte Ecclesie Loviciensis seniori vocacione conferatur, quando aut quociens per cessum vel decessum illud vaccare contigerit. Quo assecuto ipse altarista vicariam suam sımpliciter dimittere et in unico altarı contentus esse debebit. Qui eciam altarista circa dictam Ecclesiam Loviciensem residenciam personalem facere necnon superpiliciatus incensacionibus ${ }^{e}$ et processionibus interesse simili modo teneatur et sit astrictus. Qui si allud beneficium assecutus fuerit, extunc ipsum altare vacare decernimus ipso facto, ad quod tunc licitum erit alium vicarium seniorem presentare. Ius vero patronatus et presentandi dicti altaris prefato Iacobo decano vita sibi conmittente, post mortem vero ipsius prelatis et canonicis ac toti Capitulo dicte Ecclesie Loviciensis, de consensu et voluntate eiusdem Tacobi decani, reservamus et conferimus per presentes. In cuius rei testimonium nostrum et dicti Capituli nostri Gneznensis sigilla presentibus sunt appensa. Actum et datum in Lovycz feria secunda infra octavas Nativitatis beatissime Virginis Marie anno Domini millesımo quadringentesimo sexagesimo quinto, presentibus venerabilibus et honorabilibus dominis: Benedicto de Lopyenno canonico Gneznensi et Cracoviensi, Curıe nostre cancellario ${ }^{23}$, Nicolao de Kelkovicze baccalario in decretis, preposito Loviciensi et Lanciciensi ${ }^{24}$, Mathia de Borzanczicze ${ }^{25}$ predicte Loviciensis canonicis et Stanislao de Gssowo vicario perpetuo canonicali Unyeoviensis ${ }^{26}$ Ecclesiarum aliisque pluribus fide dignis testibus circa premissa. Benedictus de Lopyenno Gneznensis Cracoviensis canonicus, Curie Archiepiscopalis cancellarius manu propria scripsit.

22 Ottarz św. Jakuba stat po prawej strone nawy koścrelnej. W kolegiacie toivickiej byio $w$ cragu wieków wiele ołtarzy, zmzenıanych co do miejsca $\imath$ nazwy.

23 Benedykt $z$ Eopıenna, wsi koścrelnej $w$ dek. kłeckim (Eopreński) h. Lubicz, dr ob. prawa, kanonik włocławskı przed r. 1461, gnıeźnieński, krakowski $\imath$ kanclerz kurii arcybıskupa Gruszczyńskıego - wszystko $w$ 1464, takız kanclerz arcybpa Sienzeńskiego od 1476, zm. w 1480 (Korytkowski: Prataci, t. II, s. 528--531.- PSB, t. I (1935), s. 426-427.- Kurasiowa: Kancelaria, s. 141, nr 106).

24 Mikotaj z Kiełkowzc - zob. nr 6, przyp. 26.

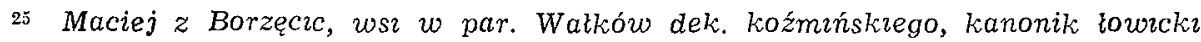
(Nie ma go w Katalogu Wieteski).

2a Stanistaw $z$ Gzowa, ws na ter par Janistawrce $w$ dek. skierniewrckim, wikarıusz kolegraty unıejowskıej. 
Lowicz, 3 kwietnia 1467

Jan arcybiskup gnıeźnieński, prymas ı kanclerz Król. Polskiego, w porozumieniu z kapitula lowicka, na miejsce istniejacych dotad zwyczajnych (manualnych) wikaruuszy $w$ tamt. kolegiacie, eryguje kolegium wikariuszy $i$ jednocześnıe mansjonarzy wreczystych, skladajace się z wiceprepozyta i 12 wikariuszy (po jednym dla 3 prałatów i 10 kanoników). Zasadniczym zadanıem kolegium będzie pelnienie duszpasterstwa $w$ kolegiacie $\imath$ parafii $w$ miejsce pratatów i kanoników, którym - na podobieństwo innych kapitul kolegiackich — prymas niniejszym rozluźnia obowiazek rezydencji. Glówne uposażenue kolegıum będzie pochodzić z czynszów od sumy 1400 flor. weg., przeznaczonych (w r. 1460) testamentalnie przez bıskupa krakowskiego Tomasza Strzępińskiego wlaśnie na erekcję tejże instytucji, ulokowanej na procent na kilku wsiach szlacheckich, $z$ dziesiecin, które posiadali już wikarıusze zwykli ze wsi Rogoźno, Jasień $i$ Ruchna, $z$ dziesięciny snopowej darowanej mu teraz przez arcybiskupa ze swego stotu, za zgodá kapituly metrop. gnieźnieńskiej, ze wsi Lubianków, Trzcianka $i$ Wola Bylina, wreszcie dochody z parafii. Prezentowanie kandydatów na wikarie $i$ mansjonare przyznaje prymas poszczególnym pralatom $i$ kanonikom, którzy będa tego dokonywać na ręce prepozyta kapituly Mikolaja z Kielkowic a potem jego nastepców. Jurysdykcja nad wikariuszami spoczywa u ręku prepozyta, w praktyce zaś wiceprepozyta.

Or. nie znany. Byt w AAW przed r. 1939 pod nrem 34 (60) - nota ks. Kwiatkowskiego w kopıariuszu Sladeckiego, s. 95.

Fot. (poczatek) - Kwiatkowskn: Kapitula, po s. 72.

Wp. AAG: Liber beneficiorum ( $z$ r. 1523), rps.

Kop. 1. AAW: Kopıariusz Janıckiego z r. 1749, s, 30-35. Tytut: Copıa privilegii fundationis et erectionıs novae Viccarıarum et Mansionariarum Perpetuarum Ecclesıae Collegiatae Lovıcensıs - -

2. Not. publ. i kap. gnızźn. Francıszka Salezego Walińskiego, sporz. w końcu XVIII w. z wpisu i uwierz., stanowiaca podstawe kop. 3, nie znana.

3. AKE: Koplariusz Sladecklego sprzed $r .1810$, s. 95-103. Tytul: 1467. Privilegium erectionis Vicarıorum et IMansionarıorum Ecclesıae Collegaatae Loviciensis J. Gruszczyński.

Wyd. Liber beneficiorum, t. II, s. 516-520.

Reg. 1. Wizytacje dóbr, s. XLIX, nr 280.

2. Librowski: Sumarrusz, nr 21.

Wzm. Wizytacje dóbr, s. 16-17.

Lit. Kwiatkowskı: Kapitura, s. 67-71.

Uw. O poczqtkach wikarıuszy w kolegracıe lowickıej zob. przyp. 2.

In nomine Domini amen. Iohannes Dei gracia Sancte Ecclesie Gneznensis archiepiscopus et primas ac Regni Polonie cancellarius ${ }^{1}$. Ad perpetuam rei

9. 1 Jan Gruszczyńskı arcybiskup - zob. nr 7, przyp. 1. 
memoriam. Quemadmodum. unigenitus Dei Filius excellentıssimam matrem suam Virgınem Mariam pre ceterıs sanctis alcuus in celestibus collocare disposuit, ita ipsam venerarı a suis fidelibus voluit nobis exemplum insinuans, debere ad hoc summopere intendere, quanta charitatis dulcedine decorem domus Dei, cultus, honorıs et glorie pro honore huius gloriosissime Virginis Marie, domine nostre, valeamus sublimare; nam sicut ecclesiarum vigor ex defectu personarum in precipicium " Ignommie $^{b}$ prostemitur, ita sıquidem ex multiplicate personarum idonearum de statu proclivi ad profectum " Immensi culminis elevatur et debitis honoratur obsequiis. Sane dum lustrando diocesim nostram salutemque animarum procurando " ac cultum divinum augendo defectusque ecclesiarum perspiciendo ${ }^{\circ}$, in opidum Lovicz mense nostre archiepıscopalıs tandem venientes luculenter comperimus, Ecclesiam Collegiatam Sancte Marıe Virginus ibıdem fundatam bono dirigi regimine et multiplicum personarum pro divino cultu agendo et signanter vicariis et mansionariis manualibus ${ }^{2}$ noviter dotatis fuisse insignitam. Volentes eosdem ${ }^{f}$ vicarıos iuxta morem aliarum collegiatarum ecclesiarum ${ }^{3}$ diocesis nostre perpetuare et stabilire, ut firmati eo fervencius officiis et laudibus divinis intendere valeant atque possint; idcirco 5 vestigiis predecessorum nostrorum inherendo, habentes singularem devocionem ad merita et immensa suffrag1a Virginis Marie illibate; volentesque ipsam matrem Dei, dominam nostram, laudibus precipuis honorare et cultum divinum ex auccione personarum ipsarum in eadem ecclesia Deo in-

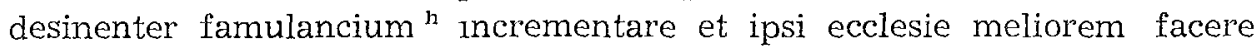
condicionem, consensu et voluntate venerabilium prelatorum et canonicorum dicte Ecclesie Sancte Marie Collegiate Loviciensis accedente expresso ${ }^{4}$, vicepreposituram, vicarias et mansionarias perpetuas in ipsa Ecclesia Collegiata Loviciensi ad honorem Omnipotentis Dei et Assumpcionıs Marie, sub cuius titulo ${ }^{5}$ extat fundata, in Dei nomine fundavimus, ereximus et creavimus fundamusque et creamus ac erigimus presencium serie literarum. Ac viceprepositum, vicarios et mansionarios et ad eos succedentes inantea intitulari et nominari perpetuos decernimus. Canonicosque singulos eiusdem ecclesie a cura animarum, quam gerebant et habebant, absolvimus

9. a principium $L B \quad$ b ignomiae kop. $1-2 \quad$ c perfectum kop. 2 ì penetrando kop. 1 e prospiciendo kop. 1-2 f brak $w$ kop. 1 g brak $w$ kop. 1 h famulatarum $L B$ i consistentibus kop. $2 \quad \mathrm{~J} \rightarrow \mathrm{J}$ onus tamen cu-

2 Wikaruszy zwyczajnych, tzw. manualnych spotkalismy w kolegiacıe łowıckiej

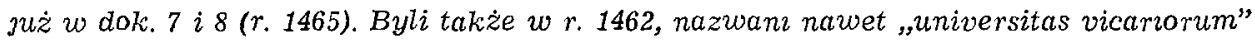
(Librowski: Sumariusz, nr 15).

3 Kolegia wikariuszy wieczystych $w$ starszych kolegiatach archidiecezji gnieźnıeńskiej (Eęczyca, Kalisz) istniaty juz na przestrzenı XIV w.

4 Por. nr 7, przyp. 10.

5 Sprecyzowany tytuł Wniebowzięcia Najśsw. Maryi Panny poświadcza dopiero ten dokument. 
ac monoculitatem et continuam residenciam ab eis et prelatis dicte Ecclesie Loviciensis relaxantes * et relaxámus; respectum ad alias ecclesias collegiatas in nostra diocesi consistentes ${ }^{1}$ habendo, in quibus prelati et canonici a talibus sunt liberi et soluti ${ }^{6} .{ }^{3-}$ Onus tum curam $^{-1}$ et regimen huiusmodi anımarum tocius parochie ipsius Ecclesie Sancte Marie Loviciensis in v1carios canonicales perpetuos in solidum transferimus et eandem ipsis committimus per eos de cetero plenarie exercendam. Prout et ipsorum canonici eandem procurabant, ita et ipsi eam exercebunt per vices seu ${ }^{\mathrm{k}}$ septimanatin. confessiones audiendo et sacramenta ecclesiastica voluntaria et necessaria ministrando temporibus perpetuo duraturis. Pretextuque huiusmodi cure animarum preter ${ }^{1}$ proventus infrascriptos ipsi vicarii canonicales curati habebunt denarium sancti Petri ac introduccionales per mulieres post partum et post nupcias offerendas. Quodque ipsi viceprepositus, vicarii et mansionarij perpetui pro decore ipsius ecclesie superpiliciis ${ }^{1}$ et almuciis de pellibus aspergellorum, biretis parvis aliisque insigniis infr? divina officia in ipsa ecclesia agenda temporibus affuturis incedere et ut1 debebunt luxta ritum aliarum ecclesıarum collegiatarum, et alias tales se exhibeant per opera virtuosa, quod onere eis commisso simplices vita et exemplis laudabilibus edificent et instruant ad salutem. Et quia beneficium datur propter officium, ideo statuimus et decernimus, quod viceprepositus cum duodecem ${ }^{m}$ vicariis perpetuis pro tempore existentibus horas canonicas diurnas et nocturnas cum missa matura de beata Virgine ${ }^{7}$ per se, ac summam missam cum scolaribus more solito singulis diebus voce psallere sine intermissione debebunt. Necnon et horas sive Cursum de beata Virgine, videlicet matutinum, primam, terciam, sextam, nonam, vesperas et completorium iuxta consuetudinem Ecclesie nostre Gneznensis eciam singulis diebus temporibus perpetuis; eo videlicet ordine, quod tres vicarii de gremio omnium vicariorum ordinarie et septimanatim cum altarista sancti Nicolai in capella sub organo fundati ${ }^{8}$, ac cum sacristiano et magistro scolarum pro tempore existentibus ad honorem Omnipotentis Dei et matris eius sancte Marie, domine nostre ac ob salutem olim reverendi ${ }^{\text {n }}$ patris domini Thome episcopi Cracoviensis, ipsius mansionarie dotatoris ${ }^{9}$.

ram kop. 2; omnis tamen cura $L B \quad$ k sive kop. $2 \quad 1$ percipient $L B \quad{ }^{1}$ superpelliceis kop. 1; superpelliciis $L B \quad \mathrm{~m}$ duodecim $L B \quad \mathrm{n}$ reverendissimi $L B$

* Przy edycji nin. dokumentu dotad postugiwatem sie jego fotokopiq.

- Np. w kolegiacie kaliskıej uwolnit tamt. kapitułę od dbowrazków duszpasterskıch w r. 1406 arcybp Mikołaj Kurowski.

7 Mszę św. poranna zw. matura i matutına ufundował $w$ kolegıacıe towzckıj dla tamt, wikariuszy manualnych $w$ r. 1452 arcybp Jan Sprowsk (Librowskı: Sumariusz, $n r$ 15).

8 Zob. $n$ r 7.

Z Zob. nr 6, przyp. 21 . 
in ipsa Ecclesia Loviciensi decantare tenebuntur. Ac insuper dicti viceprepositus et vicarii sive mansionarii missam de beata Virgine, videlicet Salve Sancta Parens, ad Cursum ipsum sive mansionariam pertinentem, per se vel per alium septimanatim, infra decantacronem horarum de ipsa beata Virgine, in summo vel alio in choro altarı submissa voce ${ }^{\circ}$ legere et complere sine intermissione debebunt et sint astricti temporibus eviternis. Necnon dictus viceprepositus et duodecem ${ }^{m}$ vicarii, et duo $\mathrm{ex}^{\mathrm{p}}$ eis septimanatim ministrantes diebus dominicis et festivis ad altare in dalmaticis cantanti ${ }^{\mathrm{a}}$ summam missam minstrabunt, et in vesperis utrusque et matutino antiphonas incipient et psalmodiam intonabunt et versum circa responsorium decantabunt. Viceprepositus autem specialiter defectus et negligencias chorı videre et emendare ac negligentes vicarios penis mulctare debebit et potestatem habebit. Verum quia qui sentit onus, sentire debet et commodum et qui altari servit, de altari vivere debet; ideo iuxta statutum et dotacionem prelatorum et canonicorum predicte Ecclesie Loviciensis ordinamus et decernimus, quod viceprepositus racione oneris, quod pro preposito ferat, habere debebit ultra alios proventus a Nicolao de Kyelkovicze moderno preposito ${ }^{10}$ et suis successoribus, prepositis ${ }^{r}$ Loviciensibus, unam marcam communis pecunie pro festo sancti Martini ${ }^{11}$ per prepositum pro tempore existentem solvendam. Quodque ipse viceprepositus, vicarii et mansionarii una cum altarista sancti Nicolai, sacristiano et magistro ${ }^{\mathrm{s}}$ scolarum pro annuo censu sive salario habebunt, possidebunt et in usus ipsorum convertent census pro mille quadringentis florenis Hungaricalibus pro ipsa mansionaria fundanda per prefatum dominum Thomam episcopum Cracoviensem legatis et datis, emptos et comparatos; videlicet apud nobiles dominos Iohannem Mszurka de Gawlovo iudicem Gostinensem ${ }^{12}$ decem sexagenas, apud Nicolaum ${ }^{t}$ baccalarium et Iohannem fratres de Syroky ${ }^{13}$ decem sexagenas, apud Albertum Sathkowski iudicem Ravensem ${ }^{14}$ decem sexagenas, apud Paulum Jasyenski ${ }^{15}$ octo marcas cum sedecem ${ }^{\text {u }}$ grossis, apud Nicolaum Dobrzelewski ${ }^{v}$ in Chlochovo ${ }^{16}$ quinque marcas, item apud

\footnotetext{
- voco $L B \quad$ p dwukrotnie $w$ kop. $1 \quad q$ cantentes $L B \quad r$ dwukrotnie $w$ kop. 1 s ministro kop. 2 t nobilem kop. 2 u sedecim $L B$ v Dobrze-

10 Zob. $n r$ 6, przyp. 26.

11 Zob. nr 5, przyp. 73.

12 Jan Mzurka czyli Bzurka z Gawtowa w par. Sochaczew h. Jelita, sędzaa gostyniński.

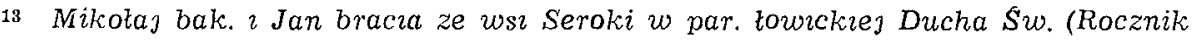
1958, s. 316).

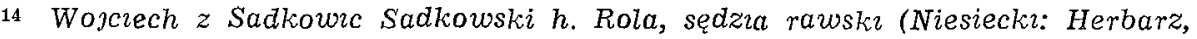
t. VIII, s. 227).

15 Paweł Jasieński albo Jasiński h. Sas.

16 Mikoła Dobrzelewskı z Chochołowa w par. Żychlin h. Poraj.
} 
Nicolaum et Iohannem fratres de Orlow ${ }^{17}$ quatuor cum media marcas, totum in mediis grossis. De quibus parcientur et dabunt altariste sancti Nicolai et suis successoribus tres cum media marcas, sacristiano tres marcas et magistro ${ }^{\mathrm{s}}$ scolarum tres marcas racione decantacionis ${ }^{\text {w }}$ horarum de beata Virgine. Et residuas pecunias predicti census pro quolibet ipsorum omnium vicariorum tres cum media marcas equaliter dividendo assignabunt. Et quociescunque contingat reempcio census in parte vel in toto, extunc viceprepositus, vicarii et mansionarii pro pecunia et capitali summa, quam ab reemptore ${ }^{\mathrm{x}}$ recipient, alium similem censum de sciencia ${ }^{\mathrm{y}}$ et consilio prelatorum et canonicorum emere et comparare tenebuntur. Item prefati viceprepositus et duodecem ${ }^{\mathrm{m}}$ alii vicarii pretextu vicariarum habebunt, percipient et inter se equaliter divident decımas in Rogoszno ${ }^{18}$ manipularem et decımam linı sive canapi ibidem pecunialem per duos grossos de quolibet manso solvendam. Item decimas in Jassyenye ${ }^{19}$ et Ruchna ${ }^{20}$ manipulares post agros et araturas kmethonum ex fructibus crescentibus provenientes. Item ipsi viceprepositus, vicari omnes et singuli ac magister scolarum pro tempore existens totum offertorium, oblaciones, questus ac omnia funeralia, vigiliales, spolia tam in pecuniis, quam in pannis, cuiuscunque fuerint materiei ${ }^{2}$ et columbacionem de civitate Lovicz arbitrariam inter se equaliter distribuant et dividant, et medietatem quindecime porcionis campanatori dabunt irrecuse ${ }^{\text {aa }}$. Insuper testamenta, domos, agros, prata et ortos pro Ipsis vicariis et eorum universitate legata et data habebunt, exceptis testamentis et aliis legatis specialiter pro prelatis et canonicis ac pro fabrica et ornamentis ecclesie ac sepultura, pannis sericeis, cera, cereis, luminibus sive candelis, clenodiis et aliis vasis in auro, argento pro ecclesia legatis et datis, que duntaxat ad prelatos et canonicos ac Ecclesiam Loviciensem volumus pertinere et spectare. Censusque et alia prescripta et ipsis vicariis et mansionariis data et assignata auctoritate nostra ordinaria de certa nostra sciencia ratificamus, approbamus, incorporamus et in robur perpetue firmitatis recipimus, decernentes dictos census et proventus seu alios loco ipsorum succedentes deinceps ecclesiastice subiacere libertati; quodque pro ipsius census recuperacione ad ecclesiasticum iudicem habeant ${ }^{\text {ab }}$ recursus. Et quia pro sustentacione competenti tot personarum census et

linski kop. $1-2$ w brak $w$ kop. 2 x reemptione kop. 2 y sententia kop. 1 z manervii kop. 2 aa irretuse kop. 1 ab habeatur kop. 1 ac misericor$17 \quad$ Mikołaj 2 Jan bracıa z Orłowa (wsi koścılnej $w$ dek. żychlińskim) Orłowscy h. Orla.

18 Rogoźno, wieś na ter. par. Domaniewice w dek. łowickim Ducha $\$$ w. (Rocznik 1958, s. 315.-Warężak: Stownik, z. 2, s. 71-73).

19 Jasıeń, wieś w par. Brzeziny (Diecezja tódzka, s. 165).

20 Ruchna, wieś na ter. par. Głowno w dek. strykowskim (Diecezja łódzka, s. 351).

21 Lubıanków, w̌eś $w$ par Dmosin $w$ dek. strykowskim (Diecezja łódzka, s. 349). 
proventus predicti pro ipsorum statu decenti sufficere minus bene videntur, ideo volentes, ut eciam in ıpsa Ecclesia Loviciensi per ipsos viceprepositum et duodecem ${ }^{m}$ vicarios nostrı salubris memoria ac habeatur, ipsique viceprepositus et vicarii onera suprascripta ipsis imposita et assignata commodius ad implere valeant: decimas manıpulares cuiuslibet grani et seminis in villis Lubyunkovo ${ }^{21}$ et Trczyanka ${ }^{22}$ et ae in Vola Bylynina ${ }^{23}$ in novalibus ex fructibus crescentibus post agros et araturas kmethonum provenıentes in districtu Squirnyeviciensi ${ }^{24}$ consistentes, ad mensam nostram archiepiscopalem pertinentes, cum omn iure et dominio, nichil iuris pro nobis et successoribus nostris in eisdem reservando, sub rathihabicione venerabilium fratrum nostrorum dominorum prelatorum et canonicorum Capituh Ecclesie nostre Gneznensis ${ }^{25}$, 1psis vicepreposito, vicariis et mansionariis Ecclesie Loviciensis per nos, ut premittitur, de novo fundatis, creatis et erectis ac eorum uberiori sustentacioni damus, donamus et largimur per ipsos successoresque ipsorum pro tempore existentes possidendas, decimandas, percipiendas, locandas, habendas et in usus ipsorum beneplacitos convertendas. Postremo quia pastore orbato grex sepius dispargitur et clisparsus videtur oberrare ${ }^{a}$, igitur ne ipsı viceprepositus, vicarii et omnes mansionarii sine pastore oberrare ${ }^{\text {af }}$ videantur, venerabili domino Nicolao de Kyelkovicze baccalario ${ }^{\text {ag }}$ in decretis, preposito Loviciensis ${ }^{\text {ah }}$ et canonico Lanciciensis ${ }^{\text {a }}$ Ecclesiarum et sus successoribus, prepositis Loviciensibus pro tempore existentibus, personas idoneas ad regendam curam animarum et ${ }^{\mathrm{u}}$ - ad onera alia ${ }^{\text {aj }}$ ferenda valentes ad ipsas vicarias et mansionarias, taliter per nos noviter creatas; et tocies quocies eas per cessum sive decessum vacare contigerit, ad presentacionem prelatorum et canonicorum singillatim factam, ad quos lus patronatus et presentandi ipsarum vicariarum et mansionariarum pertinere volumus, canonice instituendi et investrendi ac curam animarum et admınıstracionem spirıtualium et temporalıum vicariis canonicalibus et eorum cuilibet committendi; ac de viceprepositura eciam persone idonee providendi, ipsisque vicariis et mansionaris de se querulantibus lusticiam faciendi ac pro excessibus et crimmibus corrigendi, castigandi et iuxta canonicas sancciones censura ecclesiastica eciam mediante puniendi, distrıngendi et compellendi, vıcariisque et man-

\footnotetext{
dia $L B$ ad commodosius $L B$ ac brak $w L B$ af aberrare kop. 2 ag bacalareo $L B$ ah Loviciensi kop. 2; Lovicensi $L B$ at Lanciciensi kop. 2, $L B$ aj-as onera ad alia $L B$ ak eorum kop. $1-2$.

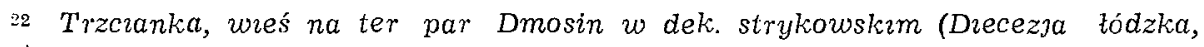
s. 349 ).

${ }^{23}$ Obec. wneś Byliny Nowe w par. Boguszyce $w$ dek. rawskim (Rocznik 1958, s. 389).

2t Skierniewnce, miasto wojewódzkie.

${ }_{25}$ Por $n r 2$, przyp. 8.
} 
stonariis chorum ${ }^{\text {ak }}$ privandi et alienandi ac domos circa ecclesiam sitas, , necnon cameras in domo nova ipsorum vicariorum constructas distribuendi et de eisdem providendi damus et concedimus omnimodam et perpetuam potestatem et facultatem per presentes. In culus rei testimonium nostrum et dict Capituli Gneznensis sigilla presentibus sunt appensa. Actum et datum in Lovicz, in Curia nostra Archiepiscopali circa castrum sita, anno Domini millesimo quadringentesimo sexagesımo septimo, die vero Veneris tercia mensis Aprilis, presentibus ibidem venerabilibus et honorabilibus dominis: Andrea Grusczynsky archidiacono Callschiensi, capitaneo Unyoviensı ${ }^{26}$ et Benedicto de Lopyenno nostre Gneznensis, Cracoviensis, Vladislaviensis ${ }^{27}$, Nicolao Malynski ${ }^{28}$ et Nicolao Beskowski ${ }^{29}$ Lanciciensis Ecclesiarum canonicis et aliis pluribus testibus circa premissa.

Lowicz, 7 kwietnia 1491

Zbigniew arcybuskup gnieźnieński $i$ prymas, pragnac powiększyć dochody dziekanatu kolegraty lowickiej, za zgoda kapituly metrop. gnieźnieńskiej i Jana z Oleśnicy starosty czyli kasztelana lowickiego, patrona tejże pralatury, wciela do jej uposażenia parafię $z$ kościolem św. Wojciecha $w$ Makowie, z której świeżo zrezygnowal na jego ręce Jakub z Kowalewic w tekścıe: z Kowala - jednocześnie dziekan lowicki. Par. Maków będzie w dalszym ciagu do niego należala - nie jako do zwyklego plebana, ale pralata lowickiego.- Dokument spisal $w$ formie instrumentu notarialnego Wawrzyniec s. Piotra z Wawrzeńczyc not. publ.

Or. nie znany. Wr 1509 byl w Arch. Kap. Gnieźn. - zob. niżej uw. 3.

Wp. AKL: Akta kap. low., t. III $z$ l. 1624-1636, s. 423-427 (wcrag. tu $z$ uwrerz. odpisu wyk. 28 IV $1634 z$ Liber privilegrorum kap. gnieźn., omaw. niżej pod kop. 1, obec. nie znanego). Tytuk: Ingrossacio unionis Ecclesiae Parochialis Makoviensis Decanatur Lovicrensı.

Kop. 1. (wspólcz.). AAG, B5: Kopiaruusz z l. 1459-1585, k. 85-86v. Tytul: Unıo et incorporacio Parrochialis in Makow pro Decanatu Ecclesie Collegiate Sancte Marle in Lovicz.

2. AKE: Koprarusz Śladeckıego sprzed r. 1810, s. 112-117 Tytur: 1491. Incorporatio Ecclesiae Makoviensis Decanatur Lov.

Reg. Librowskz: Sumarusz, nr 25.

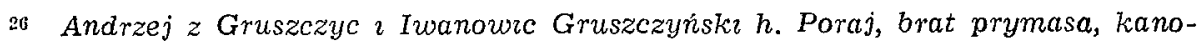

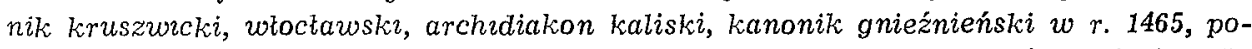
znański 1467, starosta arcybiskupı uniejowski, zm. 1482 (Korytkowski: Prałaci, $t$. II, s. 160 ).

27 Benedykt $z$ Loprenna - zob. nr 8, przyp. 23.

28 Mikołaj Malińskı kanonik tęczycki.

29 Mikotaj Beszkowski kanonik tęczyckı. 
Uw. 1. Kiedy prałat dziekan lowicku utracil dochody inkorporowanej mu aktem erekcymym kapituty wr 1433 par. Piqtek (por. $n r$ 5), nie wradomo. Nastapito to przed 1491, jako ze nin. dokument nic o Piqtku nie wspomina. W 30 lat później downadujemy się (Liber beneficıorum, t. II, s. 418), ze par. Piątek nie jest juz funduszowa wspom. prałatury, a dziekan towickı jedynie posiada odnośnie do nies prawo prezenty. Patronat ten zabrat mu (dla siebie) dopiero rzad Królestwa Kongresowego $w$ r. 1823 (Koptariusz Sladeckiego, s. 881-882.-Librowski: Sumariusz, $n$ r 173).

2. Kapıtuła gnieźnıeńska zatwierdziła ten przywilej na posiedzeniu tygodnıowym 6 VI 1491: Confirmacio istius unionis est in Regestro supplicacionum anno 1491 6.mensis Iunii (Kop. 1, k. 86v; wp. s. 426).

3. Widoczne duże byly trudnoścı ze sprawa wcielenia par. Maków do beneficjum darekanatu lowrckrego, skoro arcybp Oleśnick $w$ nin. dokumencre tak wiele mówi o karach przecıwko opornym i przeszkadzajacym w tym względzie. Dość ze w r 1509 prymas Borzyszewski zdecydowat sie na potwierdzenze

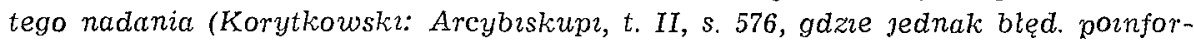

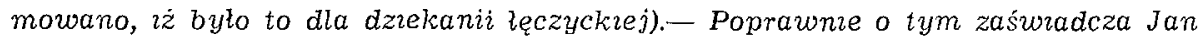

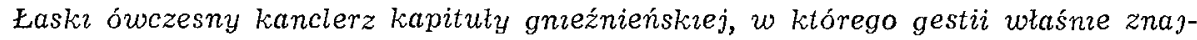
dowaty się sygillacje: Transivit per manus meas, Iohannis de Lassko coadiutoris Ecclesie et Cancellarie Gneznensis ac Regni Polonie cancellarii, dum privilegium 1509 nona Maii Ǵnezne in Capitulo reproduceretur. Cancellarius, qui supra, manu propria scripsit (Kop. 1, k, 86v; kop. 2, s. 117; wp. s. 426).

Sbigneus Dei gracia Sancte Ecclesie Gneznensis archiepiscopus et primas ${ }^{1}$. Universis et singulis presentes literas sive presens publicum instrumentum inspecturis, illis presertim quorum interest, intererit aut interesse poterit ", quosque infrascriptum tangit negocium seu tangere poterit quomodolibet in futurum. Salutem in Domino sempiternam. Ad hoc ut ecclesiarum omnium per ${ }^{b-}$ Civitatem et Diocesim Gneznesem nostram ${ }^{-b}$ consistencium et ad illarum decorem inibi destitutas dignitates obtinencium ${ }^{c}$ personarum status salubriter dirigi, servarique decencia possit honestius ac persone ipsarum divinum inibi psallentes officium ad tenendum statum suum habeant redditus; nostri libenter favoris impartimur presidium ${ }^{\mathrm{a}}$, potissime ${ }^{\mathrm{e}}$ cum temporum ${ }^{\mathrm{f}}$ requirit ${ }^{\mathrm{g}}$ necessitas, cause persuadent racionabiles et divini cultus augmentum salubriter id exposcit. Considerantes igitur satis providenter, quod decanatus Ecclesie Collegiate Sancte Marie Lovicensis, qui inibidem dignitas non tamen principalis existit nostre Gneznensis Dio-

10. a brak $w$ kop. $1 \quad$ b-b civitates Diaecesis Gnesnensis nostrarum kop. 2 c optinencium kop. 1 a praesiduum kop. 2 e potissimum wp., kop. 2

10. 1 Zbigniew $z$ Oleśnicy (wsi kościelnej w dek. stopnickim) Oleśnicki h. Dębno ok. 1430-1493. Mgr sztuk wyzw., kanonił gnieźnieński, włocławski, sandomierski, kanonik a nast. scholastyk i prepozyt krakowski; biskup wtockawski 1473-1480, arcybiskup gnieźnzeńsk i prymas 1481-1493. Pisarz król. 1451, sekretarz 1470, sekretarz w. 1472, podkanclerzy kor. 1472-1476. Czynny na polu koścıelnym थ państwowym (Eętowskı: Katalog, t. III, s. 399-405.- Korytkowskı: Arcybiskupı, t. II, s. 446-493; t. V, s. 339.- Fijatek: Ustalenie, s. 65.- Szostkiewicz: Katalog, s. 135-136.- Kurasiowa: Kancelaria, s. 145, nr 120). 
cesis et qui ad presentacionem capitanei sve castellani castri nostri Lov1censis pro tempore, qui laicus esse consuevit, pertinet ${ }^{2}$, adeo in suis redditibus et proventibus tenuis et exilis est ${ }^{3}$, quod illius decanus iuxta sui status condecenciam commode se sustentare et onera omnia dicti decanatus eidem incumbencia perferre non poterat. Etsi parroch1alis ecclesia sancti Adalberti in Makow ${ }^{4}$ dicte nostre Gneznensis Diocesis, que dum pro tempore vacat ad collacionem et provisionem nostras $^{\mathrm{h}}$ ac nostrorum predecessorum pertinet et pertinebat, dicto decanatul uniretur ${ }^{1}$, annecteretur et incorporaretur, per hoc statui decani dicte Ecclesie Collegiate Lovicensis pro tempore existenti, necnon eidem Ecclesie Lovicensi plurimum provideretur cultusque divinus exinde augmentaretur in eisdem. Quare his excitati et permoti ex causis, et presertim, ut prefatus pro tempore decanus se commodius sustentare possit, premissis providere volentes, ante omnia de omnibus et singulis premissis ac eorum circumstanciis universis requisivimus et diligentem inquisicionem fecimus. Et quia per diligentem et legitimam informacionem et testium ' fide dignorum causa huiusmodi rei ex officio nostro receptorum et iuratorum sufficientem examinacionem et deposicionem, omnia et singula premissa reperimus veritate fulciri. Idcirco auctoritate $^{k}$ nostra ordinaria, qua fungimur ${ }^{1-}$ hac in parte ${ }^{-1}$, parrochialem ecclesiam sancti Adalberti in Makow predictam, eciamsi eius disposicio, collacio, provisio seu ${ }^{1-}$ quevis alia ordinacio ${ }^{-1}$ pro hac vice ad nos ex resignacione venerabilis viri domini Iacobi de Cowalye ipsius ecclesie moderni et ultimi rectoris, qui eciam dicti decanatus Lovicensis modernus decanus existit ${ }^{5}$, per liberam illius resignacionem in manibus nostris sponte et libere factam et per nos admissam, nunc vacantem pertineat, prout de presenti spectat et pertinet, de venerabilium dominorum fratrum nostrorum prelatorum et canonicorum Capituli ${ }^{\mathrm{m}}$ - nostre Ecclesie Gneznensis ${ }^{-\mathrm{m}}{ }^{\mathrm{ac}}$ aenerosi domini Iohannis de Olessznycza moderni capitanei sive castellani castri Lovicensis, prefati decanatus Lovicensis patron ${ }^{7}$ consensu et volun-

$f$ temporis wp., kop. $2 \quad \mathrm{~g}$ requisivit kop. $2 \quad \mathrm{~h}$ nostram wp., kop. $2 \quad$ unlreretur wp., kop. $2 \quad$ j testimonium kop. $2 \quad \mathrm{k}$ authoritate kop. $2 \quad 1-1$ in hac parte kop. $1 \quad{ }^{1-1}$ alia quevis ordinacio kop. $1 \quad \mathrm{~m}-\mathrm{m}$ ecclesie nostre Gne-

2 Pratatury 2 kanonie łowrckie, usianowione dokumentem erekcyjnym tamt. kapituty w r. 1433, byty patronatu starosty towicklego, którego z kolez mianowat arcybiskup.-Por $\mathrm{nr} 5$.

3 Uposazenıe dzıekana towickıego jest wyszczególnıone we wspom. akcie erekcyjnym kapituty. Byta do niego wcielona par. Piatek.- Zob. nr 5 i tutaj uw. 1.

4 Par. wiejska Maków $w$ dek. skierniewickim (Rocznik 1958, s. 425.- Warężak: Stownik, z. 1, s. 239-242). - Istniata ona już $w$ XIV w. Druga erekcja tej parafii (przez arcybpa W. Kota) nastapita w r. 1446 (Liber beneficiorum, t. II, s. 278-281).

5 Jakub z Kowalewic - zob. nr 8, przyp. 3.

- Por. $n$ r 2, przyp. 8.

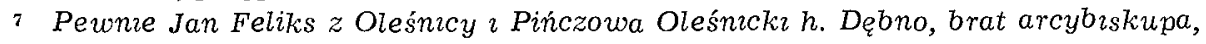
zm. 1511/12 (Dworzaczek: Genealogia, tabl. 107). 
tate, cum omnibus iuribus et pertinenciis suis dicto decanatui Lovicensi in perpetuum univimus, incorporavimus et annexuimus, ac exnunc unimus, incorporamus et annectimus per presentes. Itaque eidem domino Iacobo moderno decano, ut decano Lovicensi, predicte ecclesie parrochialis in $\mathrm{Ma}-$ kow corporalem, realem et actualem, iuriumque et pertinencrarum predictorum possessionem auctoritate ${ }^{\mathrm{k}}$ propria libere apprehendere, jlliusque fructus, redditus et proventus percipere et habere, ac in 'suos " et dictorum decanatus ac parrochialis ecclesie in Makow unite usus et utilitatem convertere, et perpetuo, libere et licite applicare, pariter et retinere, alterius eciam diocesani loc aut cuiuscunque alteruus superioris licencia super hoc alias nimirum requisita ${ }^{\circ}$, liceat prefatis decanis Lovicensibus pro tempore existentibus, ouibus tenore presencium ad premissa facienda concedimus facultatem et presentibus licenciam elargımur. Volumus autem, quodsi unionem, annexlonem et incorporacionem huiusmodi effectum sortir contigerit, parrochialis ecclesia in Makow debitis propterea non fraudetur obsequiis, nec animarum cura in ea aliquatenus negligatur, sed eius debite supportentur onera consueta. Que omnia et singula necnon presentes nostras literas in els contenta vobis omnibus et singulis supradictis et vestrum cuilibet insinuamus, intimamus et notificamus, ac ad vestrarum et cuiuslibet vestrum noticiam deducimus et deduci volumus per presentes. Ne de premissis ignoranciam alıquam pretendere valeatis seu ecıam allegare, vobisque nichilommus et vestrum cuilibet in virtute sancte obediencie et sub excomunicacionis pena, quam in vos et vestrum quemlibet, si mandatis et inhibicionibus nostris huiusmodi non parueritis, cum effectu sex dierum canonica monicione premissa, quorum sex dierum duos pro primo, duos pro secundo et reliquos duos dies pro tercio et peremtorro termino vobis et cuilibet vestrum assignamus, et nunc ferimus in his scriptis districte precipientes ${ }^{p}$ inhibemus, ne dicto domino lacobo pro tempore decano existente, dicte ecclesie in Makow vel procuratori suo, quominus corporalem, realem et actualem dicte parrochialis per nos, ut premittitur, unite, prout ad presens vacat, iuriumque et pertinenciarum elusdem, eciam auctoritate propria libere apprehendere eiusque fructus, redditus et proventus in suos predictique decanatus Lovicensis usus et utilitatem convertere valeat, ut prefertur. Omniaque ${ }^{q}$ et singula supradicta suum debitum sorciantur effectum, impedimentum aliquod prestiteribis ${ }^{x}$, per vos vel alium seu alios, publice vel occulte, directe vel indirecte, quovis quesito colore vel ingenio aut pretextu impedientibus dederitis, seu alter vestrum dederit consilium, auxilium et favorem; absolucionem vero omnium et singulorum, qui prefa-

znensis kop. $1 \quad \mathrm{n}$ suis $w p$. , kop. $2 \quad \circ$ requisitus kop. 2 p percipientes kop. 2 q Omnia kop. 2 r praestituris kop. $2^{\mathrm{s}-\mathrm{s}}$ Nativitatis wp., kop. 2 
tam nostram excommunicacionis sentenciam incurrerint quoquomodo, nobis tantummodo reservamus. In quorum omnium et singulorum fidem et testımonium premissorum presentes literas sive presens publicum instrumenium, huiusmodi resignacionem, unionem et incorporacionem in se continentes sive continens, exinde fieri et per notarium publicum Curieque nostre Causarum ${ }^{8}$ et facti presentis coram nobis scribam infrascriptum subscribı et publicari mandavimus nostrique sigilli iussimus appensione communir. Datum et actum in Lowicz sub anno ${ }^{\mathrm{s}-}$ a Nativitate $^{-\mathrm{s}}$ Domini millesimo quadringentesimo nonagesimo primo, indiccione nona, die vero septima mensis Aprilis, pontıficatus sanctissimı in Christo patris et domini nostri, domini Innocencii divina providencia pape octavl, anno septimo ${ }^{9}$. Prcsentibus venerabilibus et honorabilibus viris dominis: Nicolao de LubIin custode Skarbimiriensi, decretorum doctore ${ }^{10}$, Stanislao de Schamowo canonico Lovicensi ${ }^{11}$ ac Martino de Gostinin notario publico ${ }^{12}$, nobili Stanislao de Orly ${ }^{\mathbf{1 3}}$, testibus ad premissa vocatis specialiter et rogatis.

Z.N. Et ego Laurencius Petrı de Wawrzinczicze clerıcus Cracoviensis Diocesis, publicus apostolıca et imperiali auctoritatibus notarius ${ }^{\mathrm{t}}$ reverendissimique ${ }^{u}$ in Christo domini Sbignei archiepıscopı Gneznensis ${ }^{\vee}$ et primatis Curie Causarum et factı presentıs scr1ba ${ }^{14}$; quia premissis omnibus et singulis, dum sic ut premittıtur, fierent et agerentur, una cum prenominatis testibus presens interfu, eaque omnia premissa sic fier vidi et audivi, ideo hoc presens publicum instrumentum per alıum fidelem, me aliis legitimis occupato negociis, fideliter scriptum, exinde confeci, subscripsi, publicavi et in hanc publicam formam redegi, signoque et nomıne meis solıtis et consuetıs, una cum predictı reverendissımi domın Sbıgnei archiepiscopi ef primatıs sıgillı appenslone consignavi in fidem et testimonium omnium premissorum, requisitus pariter et rogatus.

t notariatus kop. 2 u reverendissimi kop. 2 v brak wp., kop. 2.

s Późniejsza nazwa tej instytucji - to kancelaria biskupıa zadworna.

9 Pap. Innocenty VIII rzadzit Kościołem w l. 1484-1492.

10 Nikoias z Lublina dr prawa kan, kustosz kolegiaty w Skalbmierzu.

11 Stanzstaw ₹ Szamowa (wsi na ter. par Witonia w dek. teczyckim) Szamowski h. Prus, pleban par. Pszczonów przed r. 1480, kanonik towrckı przed 1491, prepozyt pr:ed 1523 (Wieteska: Katalog, s. 33).

12 Marcin z Costynina notarıusz publ. z kurii tego prymasa.

13 Szl. Stanistaw z Ortów, jednej z kilku wsı o tej nazwıe na Mazowszu.

14 Wawrzyniec s. Piotra z Wawrzeńczyc, wsi kościelnej $w$ dek. niepolomickim, duchowny diec. krakowskiej, notarusz publ. z ust. pap. z ces. oraz kancelarii zadwornej arcybpa Zbigniewa.- Jego znak notarialny (godto, pieczęć) $w$ ksztatcie lichtarza czy pacyfikalu znajduje sie w kopıarıuszu $z$ l. $1459-1585$ na k. $86 \mathrm{v}$. 
Zbigniew arcybikup gnieźnieński $~$ prymas nawiazujac do faktu, że niedawno zmarly Jakub z Kowalewic dzuekan lowicki wyrazal wole przeznaczenıa ufundowanego przez siebie oltarza św. Jakuba w kolegıacie lowıckiej, erygowanego przez arcybpa Gruszczyńskiego w osobne beneficjum, na uposażenie dla stalego kaznodziei $w$ tejże światyni; korzystajac nadto z okazji,

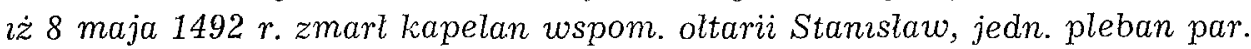
Piatek, wciela ja do erygowanego niniejszym przez siebre stalego urzędu kaznodziejskıego $w$ kolegracıe, powiększajac jej dochody dziesięcına snopowa ze wsi arcybiskupıej Malszyce, z której korzystali już miejscowi kaznodzieje zwyczajni. Jednocześnie wspom. oltarię pozbawıa charakteru „wieczystości", decyduje, ze przy stalym urzędzie kaznodziejskim jego kierownik będzie usuwalny; patronat nad nowym beneficjum oddaje arcybiskup $w$ ręce miejsc. kapituly, dokladnie jej dzrekana; na jego więc wniosek pierwszym kierownikıem kaznodziejstwa kolegıackiego mianuje prezbitera Piotra z Krasnopola.

Or. nie znany. Przed. r. 1939 znajdowal sie $w$ AAW pod nrem 4 (38) - nota ks. Kwratkowskıego w koprarıuszu Sladeckiego, s. 117.

Fot. Kwratkowski: Kaptuta, po s. 68.

Wp. AAG: Liber beneficiorum ( $z$ r. 1523), rps.

Kop. 1. AAW: Kopiarnusz Jannckiego $z$ r. 1749, s. 38-41. Tytu?: Copıa privilegii super Praedicaturam manualem Ecclesiae Collegiatae Lovicensis.

2. AKL: Koplarusz Sladeckiego sprzed r. 1810, s. 117-123. Tytut: 1492. Privilegium fundationss Praedicatoris per Sbigneum a. G.

Wyd. Liber beneficiorum, $t$. II, s. 522-525.

Reg. Librowski: Sumarusz, nr 26.

Wam. Liber beneficiorum, t. II, s. 252 .

Uw. 1. Dokument erekcyony oltarii św. Jakuba $w$ kolegracie lowıckieg $z r$. 1465 jest wyzej pod nrem 8.- Por tutaj przyp. 4.

2. O dwóch kaznodziejach manualnych ıstniejących $w$ tejże kolegiacie od r. 1433 zob. przyp. 12.

In nomine Domini amen. Sbigneus Dei gracia Sancte Ecclesie Gneznensis archiepiscopus et primas ${ }^{1}$. Ad perpetuam rei memoriam. Convenit nobis, qui licet immeriti pastoralis cure officium tenemus, ut illos, qui pietatis actibus in presenti devotos se exhibent, post huius incolatus caliginosi transitum ad beate vite ianuam feliciter perducere valeamus. Sane quia venerabilis vir dominus olim Iacobus de Covalevıcze decanus Ecclesie Collegiate Beate Marie Lovicensis ${ }^{2}$ Diocesis nostre Gneznensis considerando, quod licet in eadem Ecclesia Lovicensi verbum Dei populo christiano pro-

11. ${ }^{1}$ Zbıgniew Oleśnıckı - zob. nr 10, przyp. 1.

2 Jakub z Kowalewıc-zob. nr 8, przyp. 3. 
ponatur, tamen quia officium ${ }^{a}$ predicacionis nedum certum directorem seu predicatorem habeat, certum altare per eum, dum viveret, in augmentum laudis divine et salutis anime sue remedium ad honorem Omnipotentis Del et Glorıosissime Virgınis Marie, sub titulo beatı Iacobı apostoli et aliorum sanctorum, in privilegio fundacionis et ereccionis dicti altaris expressorum, in ipsa Ecclesia Lovicensi fundatum et dotatum ac per reverendissimum patrem dominum olim Iohannem Gruszczynski archiepiscopum Gneznensem, predecessorem nostrum ${ }^{3}$, ad hulusmodi dict domini Iacobi decanı dotacionem confirmatum et erectum ${ }^{4}$, post obitum Stanislai parochialis in Pyantek nostre diocesis predicte rectoris et dicti altaris altariste et possessoris ${ }^{5}$, pro officio predicacionis perpetuo in Ecclesia Lovicensi predicta per nos fundando et instituendo et ${ }^{b}$ eiusdem officii directore ${ }^{c}$ seu predicatore ${ }^{\text {p }}$ pro tempore cum omnibus eiusdem altaris fructibus, redditibus et proventibus ${ }^{e}$ ac domo pro altarista iuxta eandem ecclesiam collegiatam sita, bona intra se deliberacione prehabita, deputat et voluit esse deputatum, prout in certis quibusdam literis nostris, ad instantem dicti domini decani peticionem desuper confectis, quas hic pro insertis et sufficienter expressis habere volumus, plenius continetur et habetur ${ }^{6}$. Idcirco nos dicti olim domini Iacobi voluntatem et affectum commendantes et in effectum celerius deducere cupientes, presertim cum dictum altare per obitum dicti olim Stanislai altariste et possessoris eiusdem immediati, nunc videlicet die $^{f}$ octava mensis Maii apud eandem Ecclesiam Collegiatam Lovicensem defuncti ${ }^{5}$, vacare dinoscitur, officium predicacionis perpetuum in eadem Ecclesia Collegiata Lovicensi in nomine Domini fundavimus et instituimus, ${ }^{g}$ - fundamusque et instituimus ${ }^{-\mathrm{g}}$ per presentes decernentes ${ }^{\mathbf{h}}$, ut exnunc et de cetero temporibus duraturis tale ${ }^{1}$ officium predicacionis in ipsa Ecclesia Lovicensi habeatur, Officiumque Predicacionis Perpetuum Ecclesie Collegiate Lovicensis intituletur et nominetur. Pro cuius quidem officii predicacionis dotacione et ipsius directoris seu predicatoris pro tempore sustentacione altare predictum sancti lacobi, sicut premittitur, in ipsa ecclesia fundatum et erectum cum omnibus et singulis suis fructibus, redditibus, proventibus, iuribus et pertinenciis universis, videlicet decima manipulari cuiuslibet grani et seminis ac eciam canapi in Pliczvya ${ }^{7}$, villa mense nostre

\footnotetext{
11. a officii kop. 2 b brak $w$ kop. 1-2, $L B$ c directorem kop. 1-2 a praedicatorem kop. $1-2$ e pertinentibus kop. 1 \& de $L B$ g-g brak $w$ $L B$ h decernendo $L B$ i hoc kop. 1-2 f sochaczew kop. 2, LB s Jan Gruszczyński - zob. nr 7, przyp. 1.- Dokument nin. nie uważa go za w pótfundatora ołtarza św. Jakuba w kolegiacie towickiej.

4 Erekcja oltarza i ottarii siw. Jakuba w nrze 8.

5 Stanısław pleban par. Piatek $i$ kapelan oltarii św. Jakuba $w$ kolegiacie lowic$k \imath e j, z m .8$ maja $1492 r$.

- Akta te nie zachowaty się.

$7 \quad$ Plyćwia - zob. nr 8, przyp. 4.
} 
archiepiscopahs in tenuta Squiernyevicensi 8 consistente, necnon orto et area circa pontem civitatis Lovicensis eundo versus Sochaczow ${ }^{19}$, per dictum olim dominum Iacobum decanum pro dicto altari et eius altarista emptis et comparatıs, et domo predicta pro altarista edificata et constructa, per altaristas altaris predict pro tempore a primeva ipsius fundacione et dotacione plene et integre ac pacifice et quiete tenta, habita et possessa. Adicientes ${ }^{\mathrm{k}}$ insuper et iungentes ad hec aliam decimam manipularem curuslibet grani et seminis post omnes agros et araturas kmethonales in Malischicze ${ }^{10}$, villa eciam mense nostre archiepiscopalis sub castro nostro Lovicensi consistente, provenientem ${ }^{1}$ et a tempore fundacionis Collegii ${ }^{11}$ in ipsa ecclesia pro tempore predicatoribus eiusciem designatam ${ }^{12}$ et per predicatores pro tempore racione officii predicacionis huiusmodi plene et integre, pacifice et quiete, semper et hactenus tentam, habitam et possessam concessimus, appropriavimus et incorporavimus, concedimusque, appropriamus et incorporamus usibus eiusdem predicatoris pro tempore omnibus modis promptam ${ }^{*}$; quem volumus et decernimus esse temporalem sive manualem, ita quod possit immutari et ab eodem officio alienari ex iustis duntaxat et racionabilibus causis. Ut autem metu alienacionis et mutacionis huiusmodi predicator ipse in officio ipso et proponendo verbo Dei tanto diligencius se exerceat et virtutibus ac bonis exemplis ceteris prestet, ex certıs causis, animum nostrum legitime moventibus, ac ad instantem pei1cronem Venerabilis Capituli dicte Ecclesie Lovicensis, et de expresso consensu venerabilis dominı Nicolai Cothwicz ${ }^{m}$ decretorum doctoris, decani Ecclesie Lovicensis ${ }^{13}$, cui racione hurusmodi decanatus in fundacione et dotacione altarıs predicti ius patronatus et presentandi altaristam et predicatorem fuerat reservatum et concessum, titulum prefati altaris et perpetuitatem duximus fore extinguendos ${ }^{\mathrm{n}}$ et extinguimus presentium per tenorem, ita quod de cetero altare predictum titulo perpetui beneficii careat et sit omnino vacuatum, salvis tamen oneribus per fundatorem impositis, statuentes et decernentes, quod exnunc et in futurum perpetuis temporibus

к adiicentes $L B \quad \&$ pertinentem $L B \quad$ I lekcja prawdopodobna; promptura fot., profutura kop. 1-2, $L B \quad \mathrm{~m}$ Cotlewicz kop. $2^{\mathrm{n}}$ extinguendam kop. 2,

8 Skierniewice - zob. nr 8, przyp. 6; nr 9, przyp. 24.

9 Sochaczew - zob. nr 8, przyp. 21.

10 Matszyce - zob. nr 5, przyp. 59.

11 Kapituta towrcka, fundowana $i$ erygowana w r. 1433 - por. nr 5.

12 Od czasu erekcji kolegiaty $w$ Eowrczu istnieli $w$ niej dwaj kaznodzieje zwyczajnı, którzy tez mieli peinnć obowiazki spouredników - por. nr 5.

13 Mikolas Kotwicz ze Żnına, dr prawa kan. (czy nawet ob. prawa), notarusz kapıtuly gnieznieńskiej, dziekan lowicki od 1492, kantor poznański 1493, tamt. oficjat gen. 1499. kanonik gnieźnieński 1503. Pisarz król. 1502, prawnik, poeta, zm. ok. 1508 (Korytkowsk: Prataci, t. II, s. 315-317.- Kurasiowa: Kancelaria, s. 134, nr 82.Wieteska: Katalog, s. 39). 
decanus et Capitulum dicte Ecclesie Lovicensis ad predictum officium predicacionis, quocies locus et tempus se obtulerint, eligend, nommandi et assignandi manualem rectorem seu predicatorem, virum idoneum et valentem, ipsumque mutandi, amovendi et alienandi, duntaxat ex iustis et racionabilibus causis, ut premissum est, quocies expedire videbitur, plenam et liberam habere debeant facultatem. Qui quidem predicator racione officil predicacions huiusmodi debeat predicare et proponere verbum Dei in ipsa Collegiata Ecclesia Lovicensı diebus dommicis et festivis ad populum, ac eciam diebus quadragesimalibus aliisque temporibus consuetis et locis opportunis, quocies visum fuerit et necesse pro laude et honore Del et populi christıani informacione. Quo finito exhortetur populum, ut pro pace et unitate Sancte Matris Ecclesie, felici statu Regni et pro nobis, ac pro nostre dictique olim dominı Iacobi decani, qui huiusmodi officii predicacionis primarıus fuit dotator, animarum salute orare velit, propiciacionem divinam singularius implorando. Qui eclam predicator pro tempore missas eidem altari annexas, duas videlicet pro defunctis secunda et quarta feriis, imponendo eciam specialem collectam pro sacerdote defuncto, et terciam de Beata Virgine Maria die sabbati singulis septimanis cuiuslibet anni, per se vel per alium, legere et adimplere absque omn negligencia, in quo eius conscienciam oneramus; et alias pro devocione Deum Omnipotentem pro pace et unitate Sancte Matris Ecclesie et Reipublice incremento exorando, onera quoque eiusdem altaris omnia et singula supportando, et in ipsa ecclesia superpiliciatus ${ }^{\circ}$, prout et ceteri beneficiati et altariste, horis et temporibus consuetis incedere teneatur et sit astrictus ${ }^{\mathrm{p}}$. Pro quo quidem predicacions officio nunc honorabilem virum dominum Petrum de Crasnopole actu presbyterum ${ }^{14}$, sciencia et vita probatum, prefatus dominus Nicolaus decanus una cum Capitulo dicte Ecclesie Lovicensis elegerunt, nominaverunt ${ }^{q}$ et deputaverunt ${ }^{\mathrm{r}}$, illudque sibi contulerunt per ipsum regendum, et eius onera iuxta formam preinsertam portandum, ac decimas in villis predictis Pliczvia et Malischicze una cum orto et area predictis pro suis usibus et sumptibus plene et integre occasione officii predicacionis, necnon domo pro altarista, ut prefertur, assignata ${ }^{s-}$ tollendum, percipiendum et utifruendum $^{-s}$. Quodque iam exnunc eidem Petro et in futurum alteri predicatori, et ad officium predicacionis huiusmodi sive per cessum, sive ${ }^{\mathfrak{t}}$ decessum ipsius per decanum et Capitulum Ecclesie Lovicensis predicte electo, nominato et assumpto liceat vigore presencium corpolarem, realem et actua-

\footnotetext{
extinguendum $L B \quad \circ$ superpelliceatus kop. 2, superpelliciatus $L B \quad \mathrm{p}$ adstrictus $L B$ a. nominarunt $L B \quad \mathrm{r}$ deputarunt kop. $1^{\mathrm{s}-\mathrm{s}}$ tollendi, percipiendi et uti fruendi kop. 2 t następuje per $w k o p .2$ v-v brak $w L B$ w Kalyewicze kop. 2.
}

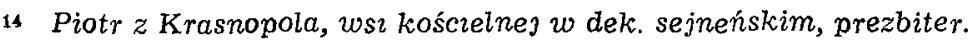


lem decimarum in Pliczvya et in Malischicze predictarum, pro dicto officio predicacionis designatarum, ac orti, aree et domus predicte possessionem libere apprehendere et pro suis usibus retmere, quamdiu in predicacionis officio huiusmodi laboraverit ${ }^{\mathrm{v}-}$ et predicaverit ${ }^{-v}$. In cuius rei testimonium nostrum et dicti Capıtuli Lovicensis sigilla presentibus sunt appensa. Datum et actum in Lovicz apud ecclesiam collegiatam eiusdem sub anno a $\mathrm{Na}$ tıvitate Domini millesimo quadringentesimo nonagesimo secundo, die vero prma mensis Iunii, nobis inibi cum venerabilibus et honorabilibus viris dominis: Clemente de Nyeznamirovicze preposito ${ }^{15}$, Iohanne de Czyechoslavicze custode ${ }^{16}$, Stanislao de Schamovo ${ }^{17}$, Nicolao de Byelavicze ${ }^{\text {w18 }}$, Iohanne Grabya de Vola Grabyna ${ }^{19}$, Paulo Chodakowski ${ }^{20}$, Iohanne de Vagancze ${ }^{21}$ et Iohanne de Grothkow ${ }^{22}$ prelatis et canonicis dicte Ecclesie Collegiate Lovicensis existentibus; presentibus eciam honorabilibus viris: Laurencio de Vawrzinczicze in Znenna ${ }^{23}$ et Paulo de Sbaschyn in Vissokinıcze ${ }^{24}$ parochialium ecclesiarum rectoribus, notariis publicis scribisque nostris, testibus ad premissa vocatis pariter et rogatis.

12.

26? sierpnia 1506

Andrzej (Róża z Borzyszewic Borzyszewski) arcybiskup metropolita gnieźnieński i prymas powtarza i potwierdza dokument erekcyjny kolegium

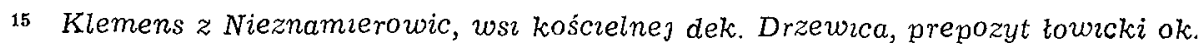
1492 (Wieteska: Katalog, s. 33).

16 Jan $z$ Ciechosławic, wsi na ter. par. Piatek $w$ dek, lęczyckim, kustosz towickı ok. 1492 (Wieteska: Katalog, s. 33).

17 Stanusław z Szamowa (Szamowski) - zob. nr 10, przyp. 11.

18 Mikotaj $z$ Bielowıc, wsi w par. Opoczno, kanonik towıckı. Ks. Wieteska (Katalog, s. 34) nazywa go, za kopiariuszem Sladeckiego, Mikołajem z Kalewicz!

19 Jan Grabıa z Grabınej Woli, wsi na ter. par. Srocko $w$ dek. tuszyńskım, kanonik towrck ok. 1492 (Wieteska: Katalog, s. 34).

20 Pawet Chodakowski h. Dołęga kanonik gnıeźnıeński $w r .1490$, towrcki ok. 1492, pleban par. Kotdrab w dek. rogowskim, kanonik reg. lat. $w$ Trzemesznie, zm. 1527 (Korytkowskı: Pratacı, t. I, s. 129-131.-Wieteska: Katalog, s. 34).

21 Jan $z$ Wagańca (wsi w par. Zbrachlin dek. nieszawskiego) Waganieckı kanonik 2 oficjat lowicki ol. 1492-1494 (Wieteska: Katalog, s. $34 z$ imienıem Piotr!).

22 Jan $z$ Grotkowa (wsi na ter. par. Jarząbkowo $w$ dek. wrzesińskim) Grotkowski $h$. Ogończyk kanonik towıcki przed 1492, tamt. oficjat i pleban $w$ St. Rawie. W

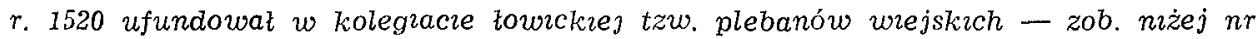
16, zm. w 1520 (Wieteska: Katalog, s. 34).

23 Wawrzyniec $z$ Wawrzeńczyc, obec. takíe pleban $w$ Żnnıe - zob. nr 10, przyp. 14.

24 Pawet ze Zbaszyna pleban par. Wysokienice $w$ dek, rawskim, notariusz publ. $i$ pisarz kancelarii arcybiskupıej. 
wikariuszy $i$ mansjonarzy $w$ kolegiacie lowickiej, wystawiony $w$ roku 1467 przez arcybiskupa Gruszczyńskiego.

Or. nie znany. W r. 1939 znajdowal się $w A A W$ - por. fot.

Fot. (poczatek). Kwatkowskı: Kapıtula, po s. 72.

Uw. 1. Miejsce wystawrenı dokumentu, wyrazone na jego końcu, nie jest mi znane.

2. Dok. erekcyjny tegoz kolegıum - wyże pod nrem 9.

\section{3}

Bolonia, 21 grudnia 1506

Juliusz II papież, na prośbe prepozyta i kapıtuły lowickiej, zatwierdza zmiany, jakie zaszly $w$ tamt. kolegiacie na skutek erekcji przez arcybiskupa Gruszczyńskiego kolegium wikariuszy i zarazem mansjonarzy, powierzenia im duszpasterstwa $w$ tejże światyni $i$ parafii oraz zwolnienia pralatów $i k a-$ noników z obowiazku ścislej rezydencji. Jednocześnie papież udziela absolucji z kar kościelnych wspom. pralatom i kanonikom, gdyby jakieś zaciagnęli z okazji tych przemian.

Or. ne znany.

Wp. $A A G$ : Liber beneficiorum ( $z$ r. 1523), rps.

Kop. 1. AAW: Kopıarıusz Janıckıego z r. 1749, s. 61-63. Tytuk: Sequitur copia bullae Julii papae erectionem et fundationem Ecclesiae Collegiatae Lovicensis confirmantis.

2. AKL: Koplariusz Sladeckiego sprzed $r$ 1810, s. 123-126. Tytul: 1506. Bulla Julii papae erectıones Collegiatae confirmans.

Wyd. 1. Liber beneficiorum, $t$. $I I$, s. 546-547.

2. Kwratkowski: Kapitula, s. 569-570.

Przekl. pol. Kwiatkowskı: Kapitula, s. 72-76.

Reg. Librowskı: Sumariusz, $n \mathrm{rr} 27$.

Lit. Kwratkowskı: Kapıtuła, s. 71-72 (nacragana interpretacja powodów wystawienia dokumentu).

Uw. Dok. erekcyıny kol. wikarnuszy w kolegıacıe lowıckiej $z$ r. $1467-w y$ zej pod nrem 9.

Iulius episcopus, servus servorum Dei ${ }^{1}$. Ad perpetuam rei memoriam. His, que pro ecclesiarum quarumlibet et personarum in illis divinis laudibus insistencium laudabili successu ac commoditatibus, necnon pro animarum cura diligenter exercenda facta dicuntur, quum a nobis petitur, adicimus ${ }^{a}$ apostolici muniminis firmitatem. Sane pro parte dilectorum filiorum moderni prepositi $^{2}$ et Capituli Ecclesie Beate Marie Virgınis oppidi Lovicensis

13. a adiicimus kop. $1-2, L B, K$ wat. $\quad$ b authoritate kop. 2 c curam kop.

13. 1 Juliusz II papıez rządził Kościołem w l. 1503-1513.

2 Klemens z Nieznamierowic - zob. nr 11, przyp. 11, albo Stanistaw Szamowski - por. nr 10, przyp. 11. 
Gneznensis Diocesis nuper nobis exhibita peticio continebat, quod alias bone memorle Iohannes archiepiscopus Gneznensis ${ }^{3}$ pro divinı cultus augmento in dicta ecclesia vicepreposituram, vicarias et mansionarias perpetuas, de consensu et voluntate dilectorum filiorum capituli eiusdem ecclesie, ordinaria auctoritate ${ }^{b}$ erexit et creavit, ac singulos canonicos ipsius ecclesie a cura animarum, quam gerebant et habebant, absolvit; necnon monocularitatem et continuam residenciam prelatis et canonicis dicte ecclesie relaxavit et absolvit ad instar aliarum dicte diocesis collegiatarum ecclesiarum, ac onus cure $^{\mathrm{c}}$ animarum et regimen tocius parochie prefate ecclesie in illius vicarios perpetuos, canonicales nuncupatos, in solidum transtulit et eandem ipsis commisit exercendam cum certıs Capituli ${ }^{\text {a }}$ ordinacionibus atque statutis super missarum et divinorum officiorum celebracione, necnon direccione et manutencione ac certis declaracionibus et determinacionibus super testamentis, domibus, agris, pratis et hortis pro ipsis vicariis habendis tunc expressis, ac nonnulla tunc expressa vicariis et mansionariis data et assignata ratificavit, approbavit, incorporavit et robur perpetue firmitatis obtinere debite decrevit. Ac tunc preposito et pro tempore existentibus prepositis dicte ecclesie personas idoneas ad regendam curam animarum et ad alıa onera facienda valentes ad ipsas vicarias et mansionarias, quocies illas per cessum vel decessum vacare contigerit, ad presentacionem prelatorum et canonicorum singillatim ${ }^{\circ}$ factam, ad quos ius patronatus et presentandi personas idoneas ad dictas vicarias et mansionarias pertinere voluit, canonice instituendi et investiendi, ac curam animarum et administracionem spiritualium et temporalium vicariis canonicalibus et eorum cuilibet committendi, ac de prepositura providendi, ipsisque vicariis et mansionariis de se querulantibus iustıciam faciendi ac eorundem excessus, crimina et delicta corrigendi, castigandi, puniendi et compellendi, vicariis et mansionariis eorum privandi et amovendi, ac domos circa ecclesiam predictam sitas et cameras in domo nova ipsarum vicarırum distribuendi et de eisdem providendi omnimodam potestatem et facultatem dedit et concessit, prout in litteris ${ }^{f}$ ipsius Iohannis archiepiscopi desuper confectis dicitur plenius contineri. Quare pro parte moderni prepositi et Capituli predictorum asserencium, se in pacifica possessione vel quasi premissorum omnium existere, nobis fuit humiliter supplicatum, ut premissis pro illorum subsistencia firmiori robur apostolice confirmacionis adicere ${ }^{g}$ ac alias in premissis opportune providere de benignitate apostolica dignaremur. Nos igitur, qui singularum ecclesiarum felicem et laudabilem successum sinceris desideramus affectibus, modernum prepositum et capi-

1-2, Kwiat. d capitulis $L b$ e sigillatim kop. 1, Kwiat. $\mathrm{f}$ libris Kwiat. $\mathrm{g}$ adiicere kop. $1-2, L B \quad$ h existunt kop. $1-2$, existent $L B \quad 1$ ac $L B \quad$ J su-

3 Jan Gruszczyński-zob. nr 7, przyp. 1. 
tulum prefatos ipsiusque capituli singulares personas a quibusvis excommunicacionis, suspensionis et interdicti aliisque ecclesiasticis sentenciis, censuris et penis, a iure vel ab homine quavis occasione vel causa latıs, S1 quibus quomodolibet innodatı existant ${ }^{\mathrm{h}}$, ad effectum presencium duntaxat consequendum harum serie absolventes et ${ }^{1}$ absolutos fore censentes,

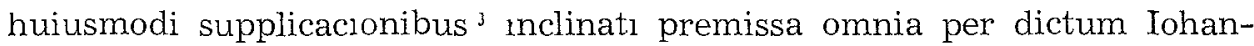
nem archiepiscopum, ut prefertur, facta ac, prout illa concernunt ${ }^{\mathrm{k}}$, omnia et singula in eisdem litteris contenta et inde secuta quecunque austoritate ${ }^{b}$ apostolica tenore presencium approbamus et confirmamus, ac omnes et singulos defectus, si qui forsan intervenerint ${ }^{1}$, in eisdem supplemus, illaque omnıa et singula perpetuo observarı debere decernimus, non obstantibus constıtucionibus et ordinacionibus apostolicis, necnon dicte ecclesie iuramento, confirmacione apostolica vel quavis firmitate alia roboratis statutis et consuetudinibus, ceterisque contrariis quibuscunque. Nulli ergo omnino hominum ${ }^{\mathrm{F}}$ liceat hanc paginam nostre absolucionis, approbacionis, confirmacionis, supplecionis et decretı infringere vel ei ausu temerario contraire. Si quis autem hoc attentare presumpserit, indignacionem Omnipotentis Dei $\mathrm{ac}^{\mathrm{m}}$ beatorum Petri et Pauli apostolorum eius se noverit incursurum. Datum Bononie ${ }^{4}$ anno Domini millesimo quingentesimo sexto, duodecimo Kalendas ${ }^{\mathrm{n}}$ Ianuarii, pontificatus nostri anno quarto.

\section{4}

Lowicz, 11 września 1510

Jan arcybiskup gnieźnieński i prymas, na prośbę Piotra z Urzędowa oltarzysty $i$ penitencjarza kolegiaty lowickiej, eryguje ufundowany przez niego $w$ tejże świątyni oltarz pt. św. Katarzyny a przy nim stałe beneficjum penitencjarskie, uposażone przez wspom. Piotra czynszem rocznym 7 grzywien pol., pochodzacym z kapitalów umieszczonych na trzech zespołach miast $i$ wsi, jak o tym pouczaja inserowane dokumenty, wyst. przez starostę lęczyckiego Mikolaja z Lubrańca. Do obowiazków penitencjarza będzie należało spowiadanı $w$ kolegiacie oraz odprawianie 2 mszy tygodniowo $z a$ fundatora, jego rodziców, krewnych $i$ dobrodziejów. Patronat nad nowym beneficjum będzie sprawowala miejsc. kapitula.- Dokument spisal $w$ formie instrumentu notarialnego Wawrzyniec s. Swiętoslawa z Powidza not. publ.

Or. nie znany. Przed r. 1939 znajdowat się $w$ AAW pod nrem 13 (40) - nota ks. Kwiatkowskiego w kopiarnuszu Sladeckiego, s. 126.

plicationibus $L B \quad \mathrm{k}$ conveniunt $L B \quad I$ intervenerunt kop. $2 \quad 1$ homini $L B$ $\mathrm{m}$ et kop. 2 n Calendas kop. 2, Kalendis Kwiat.

4 Bononia czyli Bolonia (Bologna), miasto we Wtoszech. 
Kop. AKE: Kopiarusz Śladeckiego sprzed r. 1810, s. 126-142. Tytul: 1510. Erectio Altarıs $S^{\text {ae }}$ Catharınae, tum Paenitentiarii in Collegıata.

Reg. Librowski. Sumariusz, nr 28.

Wzm. Liber beneficiorum, t. II, s. 253-254.

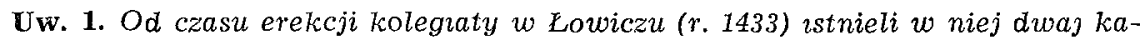

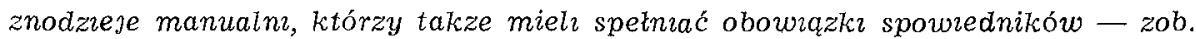
nr 5.- Na temat erekcji stałego urzędu kaznodzlejskiego w kolegiacıe por. nr 11.

2. Wspom. Piotr z Urzędowa powiększyt w r. 1517 dochody nin. oltarzysty 2 penitencjarza o dalsze 2 grzywny pol. rocznego czynszu, pochodzace z sumy

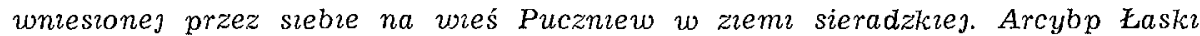
usankcjonowat dodatek, obcrqzajac beneficjata trzecıa msza $w$ tygodniu za dusze zmarlego kaptana, przyp. fundatora (Kopıariusz Siladeckiego, s. 143-144.- Librowski: Sumarıusz, nr 29).

In nomine Domıni amen. Ioannes Dei gracia Sancte Ecclesıe Metropolitane Gneznensis archiepiscopus et primas ${ }^{1}$. Ad perpetuam rei memoriam. Cum inter humane condicionis acciones et opera nihil tam salubre tamque efficax esse censeatur quam ad ea meditanda intendere, per que cultus divinus in Del ecclesiis augeatur, sane hac consideracione dilectus nobis in Christo filius honorabilis Petrus de Urzandow altarista et penitenciarıs Ecclesıe Collegiate Lovicensis Cracoviensıs Diocesis ${ }^{2}$, zelo pie devocionis accensus, cupiens cultum divinum adaugere ac metere in futurum, quod in presenti vita seminaverit, pro sua suorumque parentum et propinquorum salute altare in Ecclesia memorata Collegiata Lovicensi sibi erigi postulavit. Altariste quoque [s. 127] elusdem altaris, qui pro tempore fuerit, ut vitam congruis sustentaret subsidiis, septem marcas pecuniarum census annur monete et numer Polonicalss, quadraginta octo grossos marcam in quamlibet computando, titulo reempcionis instar, alias $\mathrm{n}$ a $\mathrm{W}$ y d e r k a uf, in et super certss bonis empti et comparati, prout in literis magnific dominı Nicolai de Ludbrancz ${ }^{a}$ palatini Calıssiensis et [Lancıciensis ${ }^{\circ}$ ] Przede-

14. ¿a Lubrancz kop. b brak w kop. c annuens kop. d redeg kop.

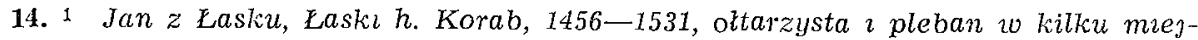
scowoścıach, notarusz publ. w 1480, kanonik poznański 1484, tamt. kantor 1486,

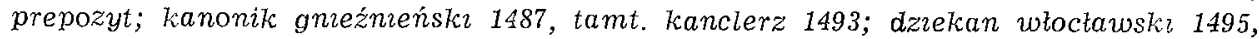

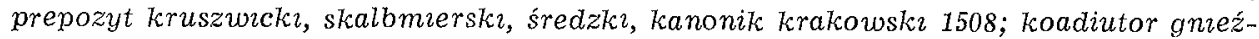

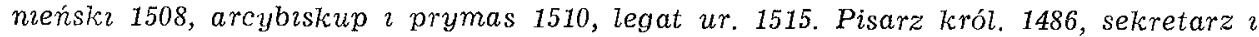
$i$ sekretarz w. 1502, kanclerz kor 1503-1510. Dyplomata kodyfikator prawa, bardzo czynny i wielce zasiuzony dla Koścıoła i Państwa (Estreıcher: Bibliografja, $t$. XXI, s. 79-83,-- N. Korbut, 2, s. 481-484.-Korytkowskı: Arcybıskup?, t. II, s. 580-739, t. V, s. 327-328.- Szostkiewicz: Katalog, s. 113.-Z. Kaczmarczyk: O kanclerzu J. Laskim, Warszawa 1955.-Dworzaczek: Genealogia, tabl. 123.- H. Kozakiewiczowa: Mecenat J Easkiego, „Biul. Hist. Szt.”, r 23: 1961, s. 3-27-Kurasiowa: Kancelarıa, s. 140, nr 103.- PSB (W. Dworzaczek), t. XVIII (1973), s. 229-237.-Hajdukiewrcz: Historia, s. 373--374).

2 Piotr $z$ Urzędowa, ws kościelnej w dek. kraśnıckim, oltarzysta niewiadomego

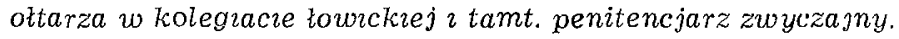


czensis capitanei ${ }^{3}$ coram nobis exhibitis, quorum tenor inferius est insertus, vidimus contineri, dedit, donavit et assignavit, nobis debita cum instancia supplicando, quatenus huiusmodi altare erigere et in beneficium ecclesiastıcum fundare et creare nostra auctoritate dignaremur. Nos vero, qui in propagacione cultus divinı intensis declaramur desideris, votis prefatı domini Petri benigniter annuentes ${ }^{c}$, dictum altare ad laudem et honorem sancte Catharine virginıs et martirıs gloriose ${ }^{4}$ in dicta Collegiata Ecclesia Lovicensi, in sinıstra parte ecclesiam ipsam a septentrione intrando, penes hostium situatum, Christi nomine invocato, ereximus, fundavimus et creavimus ac pro penitenciario perpetuo ecclesie elusdem assignavimus; erıgimusque, fundamus, creamus ac assignamus, prefatasque septem marcas pecuniarum census annui eidem altari et suis ministris, qui pro tempore fuerint, annectimus, ascribimus, incorporamus et appropriamus, nostraque auctoritate confirmamus decernentes, ut de cetero et deinceps dicti census iuri, libertati et immunitati ecclesiastıcis subiaceant, utque pro eorum repeticione ad forum iudicis ecclesiastici recurratur. Sed quia huiusmodi census sub reempcionis titulo, ut prefertur, extat comparatus, volumus decernentes quando- [s. 128] cunque ipse census in toto vel in parte reemptus fuerit, pecunia soluta in manibus altariste et patronorum reponi debet, ut alii census quanto celerius comparentur. Verum quia beneficium datur propter officium, statumus, quod altarista seu altaris elusdem pro tempore existens minister singulis septimanis anni, temporibus perpetuo duraturis, duas missas pro fundatorum parentibus, consanguineis et benefactoribus suis per se vel per alium presbyterum idoneum legat, unam feria secunda de Beatissima Virgine Marla, impositis collectis pro sacerdote defuncto et pro benefactoribus, que incipit Pietate, quesumus, Domine etc., alteram feria sexta de sancta Catharina patrona eiusdem altaris, impositis collectis de Sancta Cruce et pro vivis et defunctis; et si aliquo dierum predictorum festum solemne contigisset, extunc de illo festo missa legatur. Ius autem patronatus et presentandi dicti altaris, quocies vacacio eius contigerit, prelatis et canonicis totique Capitulo Ecclesie Lovicensis predicte, de consensu et voluntate dicti fundatoris in perpetuum reservamus et appropriamus. Ad quod quidem altare tempore vacacionis ipsius dictum capitulum personam idoneam pro officio penitencie bene valentem loci ordinario instituendam presentabit.

e brak w kop. $\quad \mathrm{f}$ Septempris kop. $\quad \mathrm{g}$ Scheczenin kop. $\mathrm{h}$ curiensibus kop.

3 Mikolaj z Lubrańca, Lubrańsk h. Godziemba ok. 1460-1524, akt. wojewoda

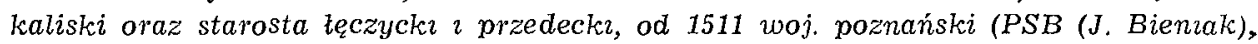
t. XVIII (1973), s. 84--85).

4 Sw. Katarzyna - zob. nr 2, przyp. 4.- Ottarz tej świętej zbudowano po lewej stronie koścıoła, blisko wejścıa. 
Następuja (s. 128-141) trzy inserowane i nie publikowane dokumenty, zapowiedziane w przywile ju zasadniczym, wyst. przez starostę lęczyckiego Mikolaja Lubrańskiego.

1) Lubrański oświadcza (Łęczyca, 17 kwietnza 1509), ze Jan Skotnicki dziedzic wsi Skotniki w ziemi lęczyckiej przyją od wspom. Piotra $z$ Urzędowa zapis 30 grzywien pol. za roczny czynsz 2 grzywien (s. 128-132).Por. Librowski: Sumariusz, $n \mathrm{nr} 28$, ins. 1.

2) Tenże Lubrańsłi oznajmıa (Łęczyca, 5 czerwca 1509), że Jan z Pokrzywnicy, za zgoda swej żony Katarzyny oraz jej brata Jana z Rogóźna, przyjal od tegoż Piotra $z$ Urzędowa na swoje dobra Pokrzywnica, Zachoclzice, Boguszyce $i$ ulice $w$ Piatku kapital 60 grzywien pol. za roczny czynsz 4 grzywien (s. 132-137).-Zob. Librowski: Sumariusz, nr 28, ins. 2.

3) Wspom. Lubrański zaświadcza (Łęczyca, 24 lipca 1509), że szl. bracia Jakub $i$ Wincenty $z$ Leszcz dziedz. wójtowie w Lęczycy, za zgoda swej matki Katarzyny, przyjęli od wiad. Piotra z Urzędowa na swoje wójtostwo lęczyckie $i$ wieś Leszcze sumę 30 grzywien pol. za roczny czynsz 2 grzywien (s. 137-141).- Por. Librowski: Sumariusz, nr 28, ins. 3.

[s. 141] In quorum omnium et singulorum fidem et testimonium premissorum presentes nostras literas scribi et in publicam formam redigi a, nostrique sigilli [appensione ${ }^{\mathrm{e}}$ ] mandavimus communiri. Datum in Lovicz anno Domini millesimo quingentesimo decimo, indiccione tredecima, pontificatus sanctissimi in Christo patris et domini, domini Iulii divina providencia pape secundi anno septimo ${ }^{5}$, die vero undecima mensis Septembris ${ }^{\mathbf{f}}$. Presentibus ibidem venerabilibus domınis: Nicolao Czepel decretorum doctore, preposito Wratislaviensi ${ }^{6}$, Clemente Bussinski ${ }^{7}$ canonicis Gneznensi-

$5 \quad$ Juliusz II papıez-zob. nr 13, przyp. 1.

6 Mikotaj Czepıel (Czepel) z Poznanıa, nob. w 1504 do h. Easkıch Korab, 14421518, ar prawa kan. 1488, notarusz publ., kortezan $\imath$ kumulant benefiçów: kanonik wrociawsh; kantor gneezneński 1461, tamt, kanonik 1482, kanonik krakowski 1486,

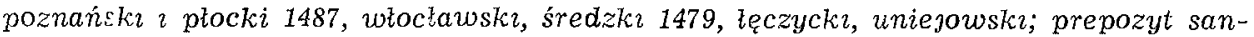

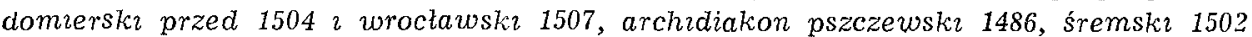
2 zawıchojski, dziekan kurzelowski, pleban par. Rudawa w dek. krzeszowıckım. Sekretarz król, vacecomes imperaalis 1481, comes Palacu Laterańskıego 1505. Agent dyplomatyczny, uczony, bibliofil (Łętowskı: Katalog, t. II, s. 160-162.- Korytkowskı: Prataci, t. I, s. 182-186.- Wisniewski: Katalog, s. 44.- PSB (H. Barycz), t. IV (1938),

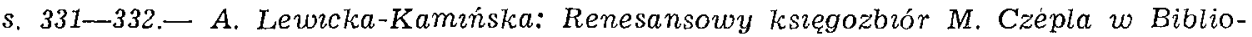
tece Jagiellońskiej, Wrocław 1956.- Kurasiowa: Kancelarna, s. 117, nr 30.- SPKP

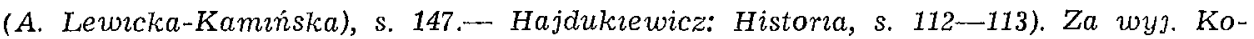
rytkowskiego 2 Wiśniewskiego wszyscy autorzy podaja btęd. rok ur.: 1452.

7 Klemens Buszyński pleban $w$ Lublinie przed 1495, kanonik lwowski przybyty $z$ arcybpem Borzyszewskım ze Lwowa do Gnezna 1503, kanonik gnieźnieñskı, kanclerz kurii arcybıskupıej $\imath$ starosta zamku lowickiego 1503, ekonom gen. dóbr arcy-

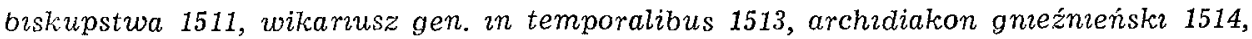
zm. w 1517 (Korytkowskı: Prałacı, t. I, s. 111-113). 
bus, Dominico de Scheczemin ${ }^{\mathrm{g}}$ decretorum doctore, archidiacono Sandomirensi, cancelları nostro ${ }^{8}$, Iacobo Schaskowskı canonico Cracoviensi ${ }^{9}$, Nicolao Krzyzanowski crucıfero ${ }^{10}$, Mathia Prussynowskı ${ }^{11}$ et Ioanne Smolyczki ${ }^{12}$ curıalibus ${ }^{\mathrm{h}}$ nostris, aliisque plurimis ad premssa testibus.

Et ego Laurencius Swantoslai de Powydz clericus Diocesis Gneznensis [s. 142] publicus sacris apostolica et imperiali auctoritatibus notarius et coram memorato reverendissimo in Christo patre et domino Ioanne Del et Apostolice Sedis gracia Sancte Ecclesie Gneznensis archiepiscopo et primate causarum et factı huius scriba ${ }^{13}$; quia predictıs omnibus et singulis premissis, dum sic, ut premittıtur, agerentur et fierent, una cum prenominatis testibus presens interful, eaque omnia et singula premissa, dum sic, ut premittıtur, agerentur et fierent, fierı vidi et audivi ac in notam sumpsi; ex qua hoc presens publicum ereccionis instrumentum, manu alterius notarii fideliter scriptum, confeci et in hanc formam publicam redegı, sıgnoque et nomme meis solitis et consuetıs consignavi, ac sigillo memoratı reverendissımı domini archıpiscopi communivi in fidem et testimonium omnium et singulorum premissorum.

\section{5}

Ok. roku 1510

Jan Łaski arcybuskup gnıeźnieñski $~$ prymas eryguje w kolegiacie towickiej oltarz pt. Bożego Ciala, ujundowany przez Grzegorza z Janisławic (wsi kościelnej w dek. skierniewickum) prepozyta kościola (szpit.) św. Jana (Chrzciciela) w Lowiczu. Oltarzysta nowego beneficjum zostaje uposażony rocznym czynszem 9 grzywien pol., pochodzacym z zapisu 180 grzywien, rozlokowanego przez fundatora na kilku majatkach w zlemi lęczyckiej i go-

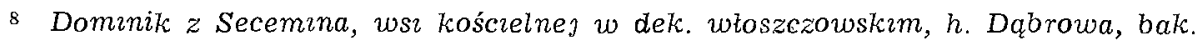
filozofii $\imath$ sztuk wyzw. $w$ 1491, dr teologii i prawa kan. 1494, archidiakon sandomierski $\imath$ kanclerz kurii arcybıskupıej ok. 1510, kanclerz gnıeźneńsk 1512, uczestnik Soboru Lat. $V$ w l. 1513-1515, pielgrzym do Ziemı Swę̨te) 1515, zm. 1519 (Korytkowski: Pratacı, t. III, s. 460-463.-Wiśnewskı: Katalog, s. 269).

9 .Jakub Szyszkowski h. Ostoja kanonik krakowski, zm. po 1527 (Eętouski: Katalog, t. IV, s. 128).

10 Mikolaj Krzyzanowski krucyfer arcybiskupa, duchowny.

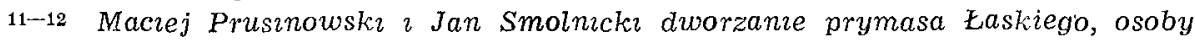
śwreckie.

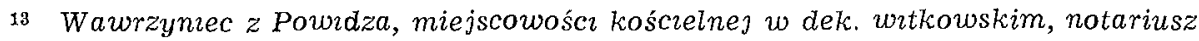
publ. $z$ ust. pap. 2 ces. oraz pısarz kancelarii zadwornej arcybpa Łaskiego od 1510, dr

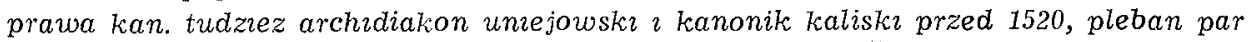

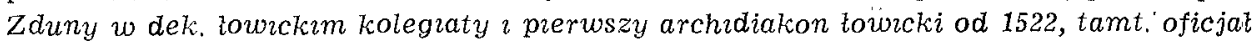
1527-1532, zm. ok. 1533 (Wieteska: Katalog, s. 39.- Librowski: Sumarusz, nr 34.Zob. nr 22, uw. 1). 
styninskiej. W zamian za to zobowiazany jest do odprawiania 3 mszy tygodniowo $w$ wyznaczonych intencjach. Patronat nad oltana otrzymuja wójt i radni miasta Lowicza.

Or. nue znany.

Wzm. - opes uposazenia oltarii Bożego Ciala: Liber beneficiorum, $t$. II, s. 254-255. Na s. 254 (zgodnie $z$ podstawa wydania) połozono jako rok erekcji: 1500. Atoli Łask objat rzady w archıdiecezji 8 maja $1510 \mathrm{r}$

Uw. 1. Fundacja oltarza musiata nastapić przed r. 1507, do którego starosta lęczyckim byli Ambrozy Pempowskı h. Gozdawa i Piotr Dunin z Pratkowic h. Ea-

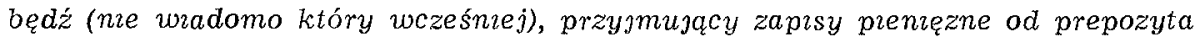
Grzegorza.- Fundator oltarza ne zyt juz podczas spısywania dochodów benefiçów w archidiakonacıe Łęczyckım (ok. 1520), do którego wchodził równzez okręg lowrcki (Liber beneficiorum, $\jmath w$.).

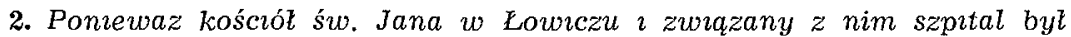
patronatu miejskiego, nic dzıwnego ze ich prepozyt powierzyt swoja fundacje $w$ kolegiacıe opiece miasta.

3. Oltarz Bozego Ciala był chron. czwartym wśród bocznych oltarzy wy-

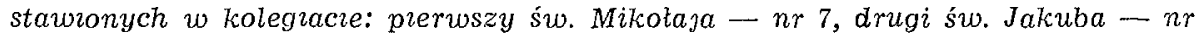
8, trzeci św. Kàtarzyny-nr 14.

\section{6}

Lowicz, 10 października 1520

Jan arcybiskup gnieźnieński, legat urodzony $i$ prymas, na przedtożenie egzekutorów testamentu śp. Jana z Grotkowa kanonika i oficjala lowickiego - w osobach: Spytka z Bużenina gnieźnieńskigo i krakowskiego oraz Stanislawa z Sierzchowa Towickiego, kanoników tudziė̇ Mikolaja z Myślakowic i Pawla z Kawęczyna wikariuszy wiecz. kolegiaty w Lowiczu - eryguje przy tejże światyni, za zgoda tamt. kapituły, z fundacji wspom. oficjata, instytucje tzw. plebanów wiejskich, zlożona $z$ dwóch kaplanów, dobieranych przez kolegium wikariuszy wiecz., którzy by rezydujac przy kościele św. Leonarda poza miastem, zaspokajali potrzeby duszpasterskie we wsiach parafii kolegiackiej, odciażajac wlaściwe kolegium do prac tylko $w$ kolegiacie $i$ na terenie miejskim parafii. Plebani wiejscy zostaja nadto zobowiazani do udzialu $w$ nabożentwach wystawnych kolegiaty oraz do odprawiania $3 \mathrm{mszy}$ tygodniowo, wskazanych przez fundatora. Za swe prace będa otrzymywać rocznie po 5 grzywien, stanowiacych czynsz od zapisanej przez oficjala sumy, na podanych $w$ innym akcie dobrach. Gdyby jednak z winy kapituty - dla której lcanonik zostawia resztę czynszu, tj. 2 grzywny $i 16$ gr, na dwa aniwersarze za spokój swej duszy - albo z powodu kolegium wikariuszy realizacja plebanów wiejskich nie doszla do skutku, wiad. czynsz 10 grzywien powinien być obrócony na fundację nowego oltarza (oltarii) $w$ kolegiacie, o czym Grotkowski poczatkowo zamyślat. 
Or. nie znany.

Kop. AKŁ: Kopiarıusz Sladeckıego sprzed $r$ 1810, s. 153-157. Tytut: 1520. Erectio Plebanorum Villanorum in Kierchow.

Reg. Librowski: Sumariusz, $n r 34$.

In nomine Domini amen. Ad perpetuam rei memoriam. Ioannes Dei gracıa Sancte Ecclesie Gneznensis archiepiscopus, legatus natus et primas ${ }^{1}$. Significamus tenore presencium universis, quomodo olım venerabilis dominus Ioannes de Grothkow canonicus et officialis Lovicensis ${ }^{2}$, considerans vicarıos perpetuos Ecclesie Collegiate Sancte Marie Lovicensis ${ }^{3}$ nostre diocesıs cura anımarum eis annexa, quam actu gerunt in eadem ecclesia, multum gravari, eo autem magis, quod dum cogerentur ire per vicos cum Venerabıli Eucharistie Sacramento ad [s. 154] parochianos villanos infirmos in longa nimis distancia, et non in parva copia existentes, tenerentur nuhilominus superappreciare aliquem sacerdotem, qui pro ess in choro cantaret, interımque redirent, et alia officia obiret, ad que eciam idem vicarii obligat sunt sub penis in eorum statutis contentis; cupiens eis a tanto labore difficultateque relevare et decori ecclesie in augmento cultus divini aliquid addere, duos sacerdotes in ipsorum vicariorum auxilium, per ipsos vicarios eligendos, manuales et ad nutum ipsorum amovibiles, ordinatos et idoneos, vita et moribus ac exemplo bonos, sub nuncupacione et vocabulo Plebanorum Villanorum. Qui tantummodo ad eosdem villanos infirmos cum Venerabili Sacramento equitarent et circa ecclesiam sancti Leonardi, in domibus eis edificandis, extra oppidum Lowycz consistentem ${ }^{4}$, semper ad hoc parati, equum sibi servando et pabulando, residerent. Tresque missas omni septimana: alteram ${ }^{a}$ pro peccatis, alteram pro pace, aliam vero pro anima sacerdotis fundatoris defuncti ${ }^{5}$, quacunque die in septimana vellent et possent, dummodo eas omni septimana explerent, sive in ecclesia

16. a alterana kop. b redirent kop. c w kop. brak poczatku zdania, moze

16. 1 Jan Lask arcybıskup - zob. nr 14, przyp. 1.

2 Jan $z$ Grotkowa (Grotkowski) -- zob. nr 11, przyp. 22.

3 Kol. wikaruszy wieczystych erygowano w kolegıacıe w r. 1467 - por. nr 9.

4 Jest to puerwsza chron. wzmianka o koścıołku pw. św. Leonarda op., stojacym $z a$ miastem na ter. par. kolegıackiej - w przyszlości szpitalnym tej parafii, tutaj jeszcze bez owej nazwy. Skromna lit. przedmıotu, opıerajaca sie na tradycji, a nie dokumentach, pragnıe go widzıeć jako b. dawny. I tak Oczykowski pısze (Przechadzka, s. 161), ze jest $z w$. XI, co powtarza ks. Wieteska (Wotum 1000-lecia w Eowzczu -

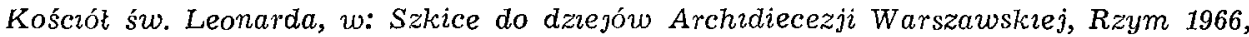
s. 90); Katalog zabytków (s. 144) przyımuje z rezerwa w. XII, za którym znowu idzze Waręzak (Stownik, z. 1, s. 201).- Z tego powodu, że nie wspominaja o nim fundacyjne i erekcyıne dokumenty lowickie: kolegiaty (r. 1433) - nr 5, par. Sw. Ducha (1404) - nr 2, klasztoru ı kościoła Domınikanów (1414) - nr 4, par. Kompina (1445) nr 6, początku jego nie można daleı cofnać jak do $w$. XV.

5-6 Ciagle mowa o fundatorze plebanów Grotkowstim. 
1lla sancti Leonardi, sive in Collegrata Beate Virginis, per se vel, quando essent impediti equitacione cum Venerabili Sacramento, per alıum legerent. Et qui teneantur semper interesse in ecclesia collegiata superpelliceati aspersionibus, thurificacionibus et processionibus, ante vicarios sicut minores incedendo, in omnibus diebus festivis et dominicis ac eciam aliis nonfestis, et presertim cum non essent occupatı his officiis, ad que fundati sunt, adiuvando vicarios [s. 155] in cantu et aliis officiis in ecclesia, eisque ut suls principalibus obediendo. Etsı aliquis de Collegio Vicarıorum vellet solus ire cum Venerabilı Sacramento ad aliquos ex predictis villanis infirmos, debeant sibi iidem sacerdotes cedere loco proque ipso in choro cantare et alia officia ecclesiastica obire, donec rediret ${ }^{b}$. Idemque facerent, quando contingeret aliquem ex elsdem vicaris vere, non autem ficte, egrotare aut cum Venerabili Sacramento ad oppidanos, prout obligantur, ire; et econtrario, quociescunque contingeret alterum vel utrumque simul ex predictis secerdotibus, plebanıs nuncupatis, similiter vere egrotare vel mori, vicarii, ut ad totam curam ipsius ecclesie collegiate ab antiquo obligati, circa quos solide manere debet, debeant providere, ne negligencia fieret in procurandis villanis infirmis tam diu, donec alium vel alios in locum suum ordinarent et sufficerent, quos ordinare teneantur quam primum poterint. [c] sine preiudicio, quinimo de consensu vicariorum ipsorum et unanimi voluntate fundavit et dotavit, dando seu testamento legando ${ }^{6}$, nomine fundi eisdem duobus presbyteris, racione prefate equitacionis ad villanos infirmos cum Venerabili Sacramento ac lectura missarum aliisque officiis per eos exequendis, ut supra premissum est. Ex duodecim marcis et sedecim grossis census annui, per ipsum dominum Ioannem fundatorem diu antea in vim reempcionis alias $\mathrm{n}$ a $\mathrm{W}$ y d e $\mathrm{rk}$ a $\mathrm{f}$ empti, prout in literis eiusdem empcionis et vendicionis, que in thesauro Capituli Loviciensis servantur, continetur ${ }^{7}$, decem marcas videlicet cuilibet ipsorum duorum sacerdotum per quinque marcas, duas vero marcas cum sedecim [s, 156] grossis eiusdem census ad duos anniversarios, per capitulum prelatorum et canonicorum presencium eiusdem ecclesie omni anno decantandos, cum missis per se vel alium legendis, quorum alter in crastino sancte Scholastice virginis ${ }^{8}$, alter vero ferı sexta ante [festum sancti ${ }^{\mathrm{d}}$ ] Urbani ${ }^{9}$ decantaretur, similiter dando et convertendo, prout eciam de hoc lacius in actis eiusdem capituli continetur. Volens idem testator et ordinans, ut quociescunque hunc cénsum simul vel successive redimi continget, tocies principalis pecunia ad alrum censum reempcionis, vel quemcunque alium firmum et certum censum tam per vicarios,

\footnotetext{
jednej linijk tekstu d brak $w$ kop. e venerabilis kop. ${ }^{\mathrm{f}}$ Syerzchowo

7 Dokument (uwierz. wypıs $z$ akt grodzkıch) raczej nie zachowany.

8 Sw. Scholastyka dziewica, siostra św. Benedykta op., zm. ok. 542. Swięto 10 lutego.

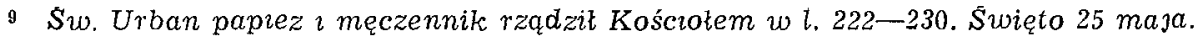


quam capitulum, et non ad aliquem alium usum, convertatur. Volens et ordinans et quo ad vicarios semper de sciencia, consilio et voluntate dominorum prelatorum et canonicorum elusdem. Ecclesie Lovicensis, quos hulus rel voluit esse superintendentes sub pena adempcionis eisdem vicariis prefatorum duorum presbyterorum in eorum auxilium per ipsum dominum Ioannem, ut premissum est, fundatorum eiusdemque census ad fundacionem altaris in eadem ecclesıa collegiata convertendi, iuxta priorem intencionem ${ }^{10}$ eiusdem domini Ioannis fundatoris. Quare constituti coram nobis executores testamentı eiusdem domini Ioannis fundatoris, videlicet venera-

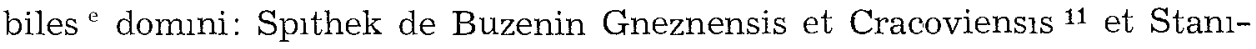
slaus de Syerzchow ${ }^{\mathrm{f}}$ Lovicensis ${ }^{12}$ canonic1, ac Nicolaus de Myslakowycze ${ }^{13}$ et Paulus de Cawyeczyno ${ }^{14}$ vicarii perpetui eiusdem Ecclesie Lovicensis supplicaverunt nobis humiliter, ut prefatam fundacionem erigere ${ }^{\mathrm{s}}$ donacionemque, dotacionem et ordinacionem ratam et gratam [s. 157] habere auctoritate nostra ordinaria approbare et confirmare, ac in iurisdiccionem et tuicionem ecclesiasticam assumere dignaremur. Nos igitur, qui semper toto cordis nostri desiderio augmento cultus divini intendimus, considerataque lusta ipsorum peticione, prefatam fundacionem duorum presbyterorum Plebanorum Villanorum nuncupatorum, de consensu et voluntate ${ }^{\mathbf{h}}$ eiusdem Collegii Vicariorum Lovicensium, ut premissum est, factam, crida legitime premissa et nemine in termino quocunque ${ }^{1}$ repugnante, in contumaciamque omnium et singulorum, sua communiter vel divisim interesse putancium, in Dei nomine erigendam, dotacionem et ordinacionem approbandam et confirmandam, in tuicionemque et defensionem ecclesiasticam assumendam et ascribendam duximus; prout erigimus, approbamus, confirmamus, assumimus et ascribimus, roburque perpetue firmitatis habere in omnibus punctis et clausulis, prout superius est expressum, decrevimus et decernimus perpetuo et in evum. In cuius rei fidem et testimonium sigil-

kop. $\quad \mathrm{g}$ regere kop. $\mathrm{h}$ w kop. następuja niepotrzebne słowa: totius Collegii Vicariorum 1 quicunque kop.

10 O takim zamiarze Grotkowskiego dowıadujemy się dopıero $z$ tego dokumentu.

11 Spytek z Burzenına (wsı kościelnej $w$ dek. złoczewskım) Bużeńskı h. Poraj, notarnusz publ. $z$ ust. ces. przeđ. 1487, pleban par. Chruślin $w$ dek. Łowickım Św.

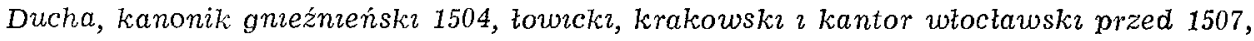
kanclerz kurii arcybpa Borzyszewskıego a potem Łaskiego $i$ z jego nominacji starosta zamku unıejowskiego, kustosz gnieźnieñsk 1518, zm. w 1527 (Eętowskı: Katalog, $t$. II, s. 103-104.- Korytkowski: Pralact, t. I, s. 113-114.-Wieteska: Katalog, s. 35-36).

12 Stanıstaw $z$ Sierzchowa (wsi na ter. par. Bednary dek. towıckıego kolegıaty) Sierzchowskı przyp. h. Drzewica, kanonik lowicki ok, 1519-1529, pleban par. Rawa (Wieteska: Katalog, s. 37).

13 Mikotaj $z$ Myślakownc, wsı w par. Łęgonıce Małe w dek. drzewickim, wikariusz wrecz. kolegraty w Eowrczu.

14 Pawel $z$ Kawęczyna, wsı nie wiadomo której na Mazowszu, wikariusz wrecz. lowecke. 
lum nostrum presentibus est appensum. Datum in Lowycz decima die mensis Octobris anno Domini millesimo quingentesimo vigesimo. Presentibus venerabilibus dominis: Spithkone de Buzenin Gneznensi, Cracoviensi et Lovicensı canonico ${ }^{11}$, doctore Laurencio de Powydz archidiacono Unyeloviensı et canonıco Calissiensi ${ }^{15}$, doctore Iacobo de Cracovia phisico nostro ${ }^{16}$, Alberto Syrmikowski ${ }^{17}$ et Stanislao Syerakowski ${ }^{18}$ de Lowycz testibus circa premissa. Transivit per manus venerabilis Spythkonis de Buzenin Gneznensis et Cracoviensis canonici, cancellarii ${ }^{11}$ suprascripti reverendissimi domini archiepiscopi.

\section{7}

Łęczyca - Lowicz, ok. r. 1520

Prawdop. Feliks Naropiński archidiakon lęczycki $i$ kanonik lowicki, wspomagany przez inna osobe, może Jana Żernickiego notariusza publ., opracowuje - na życzenie arcybiskupa Jana Laskiego - opisy dochodów beneficjów kościelnych (Liber beneficiorum) $w$ rozlegtym archidiakonacie lęczyckim, m.in. uposażen instytucji duchownych w Lowiczu i okolicy.

Or. (czyst.). AAG: Liber beneficiorum, rps.

Kop. (zwiazane $z$ kolegiata lowicka) 1. Widymat wyd. w 1 pot. XVIII $w$. przez kapıtutę metrop. gnieźn., będacy podstawa odpisu przynajmniej dla kop. 2, nie zachowany.

2. AAW: Kopiariusz Janickego $z$ r 1749,'s. 1-20, stanowiacy podstawę kop. 3.

3. AKE: Kopiariusz Sladeckiego sprzed r. 1810, s. 171-202. Tytu飞: 1521. Descriptio proventuum Ecclesiae Insignis Collegiatae Loviciensis ex Libro Beneficiorum Ioan. de $\mathrm{La}=\mathrm{co}$ a. g.

Wyd. Liber beneficiorum, t. II, s. 236-255: beneficja kolegiaty: kapitula ( 3 pralatury: prepozytura, dzıekanıa, kustodia 210 kanonikatów), kol. wikariuszy, pre-

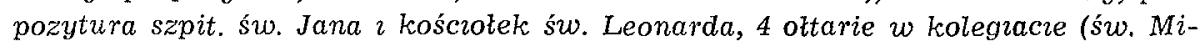
kołaja, św. Jakuba, św. Katarzyny थ Bozego Ciata); s. 255-258: par. Sw. Ducha w Eownczu; s. 263-268: par. Kompina utworzona $z$ kolegiacterej.

Reg. Librowskı: Sumariusz, nr 38.

Uw. 1. Liber beneficiorum (Easkiego) powstal między $r .1511$ a 1523 (LB, t. II, s. IV). W archidiak. tęczyckim zostaz opracowany ok. r. 1520. Swiadczy o tym (m.ln.) fakt, $\imath z$ kanonik $\imath$ oficjal touncki Jan $z$ Grotkowa, zm. w pot. 1520 (por. $n r$ 16), podczas wykonywanıa tego dzıeta byt jeszcze plebanem par. St. Rawa (LB, t. IT, 288). Dotqczona zaś w r. 1523 na końcu opisów archidiak. tęczyckıego znaczna

15 Wawrzynec z Powndza-zob. nr 14, przyp. 13.

16 Jakub z Krakowa dr sztuk wyzw. 2 medycyny, kanonik towicki $i$ pleban par.

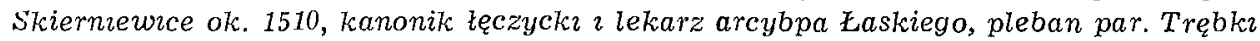
$w$ dek. gostynińskım ok. 1525, zm. po 1544 (Wieteska: Katalog, s. 38).

17 Wojciech Sirmikowski czy maże Siemikowski - por. nr 18, przyp. 30.

18 Stanistaw Sierakowsk z Lowicza, bliżej nie znany. 
ilość dokumentów towıckıch (LB, t. II, s. 507), którymi zajmuje się nr 19, me jest z nimi istotnie zwiqzana.

2. Opracowany tak, za wyjątkiem archidiak. kamieńskiego, ogólnodiecezjainy Liber beneficiorum znajdowat się $w$ kurii arcybpa Łaskıego w Eowiczu. Byt tu jeszcze za rzadów prym. Jana Wezzyka (1627-1638), którego kancelara wydawata z nego dla jakiejś parafii odpis uposazenta (Librowski: Repertorum, cz. 2, strone podam w przy zlości). Dopiero w pot. XVII stul. dzleło to przewieziono do Arch. (przech.) Kap. Metrop. $w$ Gnieźnze, która odtad az do XIX w. wydata na jego podstawie niezliczone kopie wierz. Na czele wszystkıch odpisów kladzıono zawsze r. 1521, albowiem jeden z rękopısów ksıegi (archídiak. kaliski) mial właśnıe $w$ nagłówku ten rok. Dla Łowıcza (ołtarz Bożego Ciała w kolegiacıe) pıerwszy taki widymat pozyskano w r. 1673 (Kopıariusz Sladeckiego, s. 168-171.Librowskı: Sumarusz, nr 37).

3. Obok koścıola ı szpitala św. Jana Chrzc. $w$ Lowıczu znajdowala sie $w$ r 1511 osobna kaplica pt. św. Krzyza (Wizytacje dóbr, s. 18), pewnie zastęujaca ustawicznue meliorowany koścıót, o której nie wspomina Liber beneficıorum.

4. Opisy beneficjów parafii spoza Łowicza, wclelonych do nektórych instytucji kolegiaty lowrckiej, sa przeze mnie meldowane na sworch miejscach.

\section{8}

Gnıezno, ok. 23 kwietnıa 1522

Jan arcybiskup gnieźnıeńskı, prymas i legat urodzony widzac, że archidiakonat lęczycki (archidiecezji) jest zbyt rozlegly a tamt. archiduakon nie latwo dociera do dalszych jego terenów z jurysdykcja i wzzytacjami, za zgoda kapıtuly metrop. gnıeźnıeńskiej oraz przyzwoleniem kapitul kolegiackich $w$ Leczycy $i$ Lowiczu, tudzież akt. archidiak. lęczyckiego Feliksa Naropińskiego - obıecujac pozyskanie beneplacitum papreskiego - eryguje terytoralny archidiakonat lowıckı oraz taka $\dot{z}$ pralature (jako czwarta) we wspom. kapitule, oddajac ja równeż̇ pod patronat swego starosty lowickiego. Nowy archidiakonat okręgowy ma przejać z archidiak. lęczyckiego 2 jego (pólnocno-wschodnie) dekanaty: rawski $i$ bedlneński, które mniej wiecej odpouvadaja oficjałatom foralnym lounckiemu i lęgonickiemu. $\mathrm{Na-}$ tomiast prebenda archidiakona $w$ kapitule lowickıej zajmie miejsce kanonikatu fund. Duplice Duże, po rezygnacji z niego lub śmierci kanonika Stanislawa z Zawady. Ponadto prymas wciela nin. aktem do jej uposazenia parafię Zduny, z której świeżo zrezygnowal Wawrzyniec z Powidza.-- Dokument spisal $w$ Jormie instrumentu notarialnego Jan s. Wojciecha $z$ Żernik not. publ.

Or. me znany.

Kop. 1. (wspólcz.). AAG, B5: Kopıarıusz $z$ l. 1459-1585, k. 204v-206. Tytut: Erectio Lowicensis Archidiaconatus.

2. AKL: Kopıarıusz Śladeckıego sprzed r. 1810, s. 221-227. Tytul: 1522. Erectio Archidiaconatus Loviciensis.

Wyd. Korytkowskı: Arcybıskup , t. II, s. 663-666, przyp. 9. 
Reg. Librowskı: Sumariusz, $n r 46$.

Lit. Korytkowskı: Arcybiskupı, t. II, s. 611 (błęd. informacja o dekanatach, które mıat obją́ nowy archidiakonat), s. 612, 663-666.- Kwıatkowskı: Kapıtuta, s. 76-77.- Librow kı: Statuty kapıtul, Wstęp.-J Wieteska: Archıdiakonat, jak $w$ nrze 5, s. $73-74$.

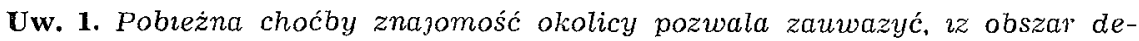
kanatów bedlneńskiego z raw kiego nie pokrywał się z terytorium ofiçalatów

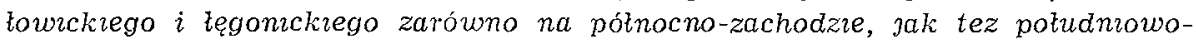
-wschodzie. Oficjalat lęsonıcki musiat obejmować równiez pótnocna część archıdiak. kurzelowskiego.

2. Dokument nin. ulegl poważnej modyfikacji w r. 1528. Por. nr 20.

In nomine Dominı amen. Ioannes Del gracia Sancte Ecclesie Gneznensis archiepiscopus, ${ }^{-}$primas legatusque natus ${ }^{-a 1}$ Ad perpetuam rel memo-

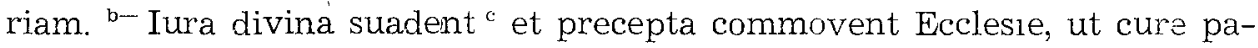
storalis provisioni, adminustracioni et impendenti a sollicitudini, quarum per se nequimus, per archidiaconales inquisıciones tam in personis, quam in ıpsis ecclesiis edibusque et rebus sacris debitum humeris nostris impendens per alios, de quibus iura perstringunt, exequamur ${ }^{-b}$ Inde est, quod nos perpendentes amplitudinem Archidiaconatus Lanciciensis ${ }^{c}$ diocesis nostre equidem non unici $^{r}$, sed multorum districtuum visitacione ${ }^{g}$ onerati $^{\mathrm{h}}$. In civitate vero nostra Lovicensi ${ }^{i}$, quam archidiaconus ipse Lanciciensis visitaturus esset, popul frequenciam esse, que quanto malor fuerit, tanto ma1ore $^{j}$ cura providenciaque ${ }^{\mathrm{k}}$ et honorificencia ecclesiastica exornanda ${ }^{1}$ foret. In qua licet ecclesia collegiata fuerıt ${ }^{1}$ per olim predecessores nostros erecta atque $^{m}$ fundata, tres prelatos, scilicet prepositum, decanum et custodem, canonicos vero in ${ }^{n}$ numero decem habens, ${ }^{c-}$ attamen quod ${ }^{-0}$ null ${ }^{-}$corum ascripta fuerit iurisdicio loci illius aliorumque locorum et personarum ecclesiasticarum circumcirca existencium 2. Que loca, ne gregem dommcum, nobis Del gracia commissum, lupi rapaces ${ }^{p}$ lacerent, aut quavis racione in eo ${ }^{\mathrm{q}}$ scandala pullulent, iure divino perhibente et consciencia nos urgente, sepe sepius obire invisereque neccessum ${ }^{r}$ est. Quod cum ${ }^{s}$ per vices $^{t}$ anchidiaconi Lanciciensis haud posset sufficienter expleri, de consilio fratrum nostrorum prelatorum et canonicorum tum ${ }^{\mathrm{u}}$ nostre ${ }^{\mathrm{v}}$ Gneznensis ${ }^{3}$,

18. a-a legatus natus et primas kop. 2 b-b brak wyd. c swadent kop. 1 a impedimenti kop. 1 e brak kop. 1, wyd. f unius kop. 2 g brak kop. 2 n onerari kop. 2 i u wydawcy $w$ calym dokumencıe lekcja o brzmıenıu meękkım: Loviciensi, Loviciensis $\mathrm{j}$ maiori wyd. $\mathrm{k}$ providendaque kop. 1 , providenda wyd. 1 exoneranda kop. 2 I fuerunt kop. 2 m et kop. 2 n brak kop. $2 \quad \circ$ tamen quia kop. 2 p mordaces kop. 1, wyd. q ea wyd. $r$ necesse kop. 2, wyd. s non kop. 2 t vires kop. 2 " tam kop. 2, quam wyd. $\mathrm{v}$ nostri kop. 2 w tam kop. 2, quam wyd. $\quad \mathrm{x}$ iurıs kop. $2 \quad$ y erigendo wyd.

18. 1 Jan Laski arcybıskup - zob. nr 14, przyp. 1.

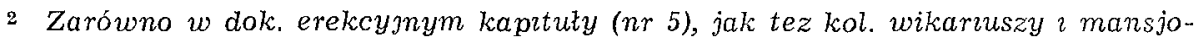
narzy (nr 9) jurysdykcję nad duchowzenstwem kolegiaty otrzymat tamt. prepozyt.

3 Por $n$ r 2, przyp. 8. 
tum ${ }^{w}$ predictarum Lanciciensis et Lovicensis ${ }^{4}$ Ecclesiarum, ad archidiaconalem dignitatem in Ecclesia predicta Lovicensi erıgendam iuxta deliberaciones iure ${ }^{x}$ consultas pnocendendum duximus. Cui denuo erigende ${ }^{y}$ pro fundo canonicatum et prebendam ${ }^{z-}$ in Ecclesia Lovicensi Collegiata predicta $^{-z}$, quorum venerabilis Stanıslaus de Zawada canonicus Lovicensis ${ }^{5}$ aa- per cessum vel decessum et alias quamlibet aliam diminissionem primo loco vacaturos ${ }^{-a}$ et plebanatum in villa nostra archiepiscopali Szduny ${ }^{\text {ab6, }}$, cuius Laurencius de Powydz ${ }^{\text {6a }}$ possessores existunt, ac- ascribendos et incorporandos ${ }^{\text {ac }}$ statuimus cum annexione iurisdicionis archidiaconalis in civitate nostra Lovicensi et Langonicensi ${ }^{a d}$. Sed ne de hoc quispiam ${ }^{\text {ae }}$ pretenderet ${ }^{\text {af }}$ sibi preiudicari, nostras citacionis in vim cride literas contra sua interesse coniunctim vel divisim putantes premittendas duxeramus et premiseramus ad videndum et audiendum huiusmodi dignitatem archidiaconalem in ipsa Ecclesia Lovicensi per nos denuo cum fundi predicti, specificacione et assignacione erigi, sibique duorum officialatum, videlicet Lovicensis ${ }^{8}$ et Langonicensis ${ }^{\text {ad } 9}$ archidiáconalem iurisdicionem adiungi, ascribi et incorporari, ac eandem iurisdicionem archidiaconalem ${ }^{\text {ag }}$ in eis duobus officialatibus ${ }^{\text {an- }}$ Archidiaconatui Lanoiciensi ${ }^{-a h}$ adimi et ab eo dismembrari, seiungi ${ }^{\text {al }}$ et dividi, aliaque tam premissa, quam que videbuntur opportuna ac que iuris ondo suaserit facienda fieri, decerni, consummari $^{\text {as }}$ et perfici, literasque desuper cum nostri disposicione ${ }^{\text {ak }}$ decreti perpetui decerni, darn et ${ }^{\text {al }}$ concedi. Et quia in termino huiusmodi citacionis noistre, debite execute, nullus, qui premissis ${ }^{\text {at }}$ contravenire et ea impugnare vellet coram nobis comparuit, preter venerabilem domınum Felicem Naro-

\footnotetext{
z $-\mathrm{z}$ szyk: praedicta Collegiata kop. 2; brak wyd. aa-aa brak wyd.; $w$ kop. $2 z a-$ miast vacaturos: vacationem ab Zduny kop. 2 ac-ac ascribendum et incorporandum kop. 2 ad Lagonicensi kop. 1 ac quidpiam kop. 2 af penderet kop. 2 ag brak wyd. ah-ah Archidiaconatus Lanciciensis kop. 2 al subiungi kop. 1, wyd. as confirmavi wyd. ak appositione kop. 2 al brak kop. 2 at premissus wyd. am Naropiński kop. 2 an Archıdiaconatus wyd.

4 Zob. nr 7, przyp. 10.

5 Stanıstaw z Zawady lub z Zawad - liczne wse o lych nazwach $w$ daw. archr-

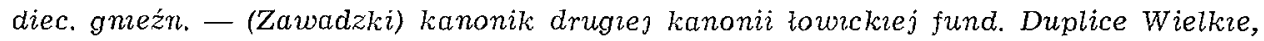
znany tylko w l. 1521-1522 (Wieteska: Katalog, s. 37).

6 Zduny, wieś $~$ par. $w$ dek. łowıckım kolegraty (Rocznik 1958, s. 310.- Zajączkowscy: Materaty, cz. II, s. 205).

6a Wawrzyniec $z$ Powıdza - zob. nr 14, przyp. 13.

7 Łęgonice, miejscowość koścuelna $w$ dek. bialskim (Rocznik 1958, s. 188-189).

8 Dotad bylo wadomo o istnienıu Ofiçatatu 2 Konsystorza For. w Eowıczu przynajmniej od $r$ 1466. Moje nie opublikowane $w$ tym względzıe badanıa nad kośczelnym ośrodkiem towickım pozwolity tę datę przesunąć na r. 1445.

9 Dotychcz. literatura prawno-hzstoryczna wiedzlata o istneniu Oficjałatu $i$ Konsystorza For w Eegonicach przynajmnıe od $r$. 1466. Nie opublikowane badania podpısanego nad tym tematem pozwalaja owq date przenieść na r. 1413.
} 
pyenski ${ }^{\text {an }}$ archidiaconum modernum Lanciciensem ${ }^{\mathbf{1 0}}$, qui coram nobis comparens consensit per expressum ad erectionem diote dignitatis archidiaconalis in prefata Lovicensi Ecclesia, et in adempcionem Archidiaconatui an suo Lanciciensi duorum decanatuum ruralium, Ravensis ${ }^{11}$ scilicet et Bedlnensis ${ }^{12}$, in omniaque et singula in predictis nostris cride literis contenta, reservando sibi duntaxat superioritatem loci in dicta Ecclesia Lovicensi tempore celebrandarum sinodorum ${ }^{13}$. Ideo erectionem dicte dignitatis in prefata Lovicensi Ecclesia et alıa omnia et singula premissa fienda et facienda decreveramus, distuleramus ${ }^{14}$ tamen negocium ipsum ex certis respectibus animum nostrum moventibus ad presens capitulum generale Natalis sancti Adalberti ${ }^{15}$. In quo quidem capitulo generali, de unanimı consensu et voluntate ommium et singulorum prelatorum et canonicorum Ecclesie nostre Gneznenisis prefate, dictam dignitatem archidiaconalem in prefata Ecclesia Lovicensi Collegiata, nemine cotradicente, in prefatis canonucatu et prebenda Lovicensi, de generosi domini ap Gregorii Sarnowski capitanei nostri Lovicensis ${ }^{16}$, tunc ${ }^{\text {aq }}$ coram nobis personaliter ar constituti, dictorum canonicatus et ${ }^{\text {as }}$ prebende racione capitaneatus predicti patroni consensu expresso, quamprimum illos per cessum vel decessum et quamlibet aliam dimissionem prefati domin Stamislai de Zawada vacare contigerıt, et certis proventibus specificandis dicte ecclesie in Zduny parochialis

ap brak kop. 1, wyd. aq brak kop. 1, wyd. ar specialiter kop. 1, wyd. as duukrotnze $w$ wyd. at certos wyd. au brak wyd. av-av brak wyd.

10 Feliks (z Naropnej na ter. par Zelechlinek w dek. rawskim) Naropıńsk h. Beına, kanonik wtoctawskı $\imath$ archidiakon lęczyck przed 1508, prowadzit spór $z$ Mikotajem Bedlıńskim o kanonię gnieźnieńska w 1508, tamt. kanonik 1510, podkolektor kontrybucji król. $w$ archıdiec. gnieźn. 1513, sekretarz król., kanclerź bpa wtoclawskie-

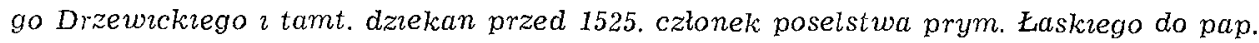
Klemensa VII w 1524, kanonik poznańsk? 1528, lownckı ok. 1529, kurzelowski, pleban par. Zadzım $w$ dek. szadkowskim; gen. ekonom dóbr arcybıskupstwa 1531-1536, wnkaruusz kapitulny gnıeźn. 1535, 1537, kanonik krakowskı przed 1540. W katedrze wloctawstiej ufundowat 1528 kaplice św. Marcina, zm. w Rzymie 1541 (Eętowski: Katalog, 't. III, s. 364.- Korytkowskı: Pratacı, t. III, s. 76-84.-Wieteska: Katalog, s. 39).

11 Rawa, miasto, ośrodek jednego z dekanatów (wıejskıch) archıdiak. lęczyckıego (Liber beneficiorum, t. II, s. 236).

12 Bedlno, wieś koścıelna $w$ dek. zychlinskım, stolica drugıego dekanatu archıdiak. lęczyckiego (Liber beneficiorum, t. II, s. 429).-- Pozostake dwa dekanaty tegoz archidiakonatu to Szczawin, do którego nalezala takze Eęczyca (tamze, s. 348) $\imath$ Tuszyn (tamze, s. 163).

13 Chodzl o synod catej archidiecezji, który odbywabby się $w$ Łowicau, jak tez o synody czastkowe, archidiakonalne.

14 Erekcję archadiakonatu lowickiego zaplanowat arcybp Łaski juz $w$ r. 1512, razem z utworzenıem archidiak. kamieńskiego (Korytkowski: Arcybiskupi, $t$. II, s. $611-612)$.

15 Swięto narodzenia (ala nieba czyli data śmierci) św. Wojcrecha - 23 kwietnia.

10 Grzegorz Sarnowski h. Ślepowron, starosta arcybıskup lowıckı. 
in Dei nomine et sub beneplacito Sedis Apostolice ${ }^{17}$ ereximus. Eidemque dictos canonicatum et prebendam, necnon ex parochialis predicte in Zduny proventibus decimas manipulares in utraque Jaczkowycze ${ }^{\mathbf{1 8}}$, in Jaszyona ${ }^{\mathbf{1 9}}$, in Strugyenycze ${ }^{\mathbf{2 0}}$ per agros advocaciales et in Wrzecze ${ }^{\mathbf{2 1}}$ per agnos prediales certis ${ }^{\text {at }}$ in ibidem incolis locatos, missalia in Lasznyki ${ }^{22}$, Zduny et Strugyenycze, et duorum decanatuum ruralium predictorum ${ }^{\text {au }}$, videlicet Ravensis et Bedlnensis archidiaconalem iurisdicionem ascribimus, incorporamus et adiungimus, ac dictas decimas et missalia in dicta parochiali in Zduny, iurisdicionemque predictam archidiaconalem in eisdem duobus decanatibus ruralibus Archidiaconatui Lanciciensi adimimus et ab eis dismembramus, seiungimus et dividimus pleno iure perpetuo per presentes. Decernentes et volentes, quatenus archidiaconus pro tempore existens dicti Archidiaconatus ${ }^{\text {av- }}$ Lovicensis sic, ut prefertur, per nos erecti titulo archidiaconatus $^{-a v}$ in dicta Ecclesia Collegiata Lovicensi superpilicio ${ }^{\text {aw }}$ et dalmucio stalloque in choro, ac cum ax ay- canonicatu et prebenda predictis ${ }^{-a y}$, quorum possessionem absque alia presentacione licebit sibi vigore presentis privilegii, quamprimum az illos per cessum vel decessum memorati domini Stanislai, vel quamvis aliam dimissionem aut quovis alio modo, ut predictum est, vacare contigerit, libere intrare, apprehendere et manu tenere, assecutus fuerit, voce et loco in capitulo, refectionibus quotidianis, anniversariis iuribusque quibusvis, quibus et ${ }^{\text {ba }}$ alii prelati et canonici dicte Ecclesie Collegiate Lovicensis et aliis prerogativis, iurisdicionibus et honoribus, quibus alii archidiaconi ${ }^{b b-}$ in ecclesiis collegiatis diocesis nostre et presertim $^{-\mathrm{bb}}$ in Ecclesia antedicta Lanciciensi utuntur, fruuntur et gaudent, utatur, fruatur et gaudeat. Mandamus insuper in virtute sancte obediencie et sub excommunicacionis pena ${ }^{b c}$, et aliis penis sinodalibus omnibus et singulis parochialium et aliarum quarumcunque ecclesiarum, monaste-

aw superpelliceo kop. 2 ax ejus kop. 2 ay-ay canonicatum et prebendam predictos kop. 1, wyd.; canonicatum et praebendam praedictos kop. 2 az quam primo kop. 2 ba brak kop. 1, wyd. bb-bb brak wyd. bc brak kop. 2

17 Pozwolenie papteskie nie byto $w$ tym wypadku konieczne. Easki miat wystapić o nie, nauczony smutnymi dośwradczenıamı w tym wzrlędzie.

18 Jackowice Wielkıe $i$ Małe, wsie w par. Zduny dek. łowackiego kolegiaty (Rocznik 1958, s. 310.-Warężak: Slownik, z. 1, s. 114-116.-Zajaczkowscy: Materiały, cz. I, s. 109).

19 Jasıonna, wieś na ter. par. Bolimów w dek. towickim kolegıaty (Rocznik 1958, s. 302).

20 Struąenıce, wieś w par. Zduny dek. lowickiego kolegıaty (Rocznik 1958, s. 310.- Za;aczkowscy: Materiaty, cz. II, s. 120).

21 Urzecze, wieś na ter. par. Sobota w dek. lowıckim $\$ w$. Ducha (Rocznik 1958, s. 320$)$.

22 Eaźniki, wheś w par. Zduny dek. downckiego kolegiaty (Rocznik 1958, s. 310.Zająckowscy: Materiaty, cz. I, s. 177). 
riorum, oraculorum, locorumque predictorum rectoribus et eorum vicesgerentibus, aliisque presbiteris et clericis in locis predictis constitutis, ut de cetero non Lanciciensi, sed ${ }^{\text {bd }}$ Lovicensi archidiacono pro tempore existenti pareant et obediant, et eum be vel suum vicesgerentem cum reverencia suscipiant procuracionesque debitas dent cum effectu. Et quia ius patronatus predictorum prepositure, decanatus, custodie et dictorum decem ${ }^{\text {bf }}$ canoni-

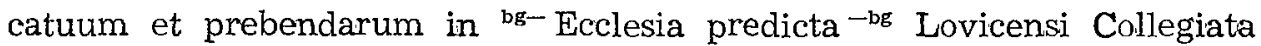
${ }^{\mathrm{bh}-}$ ad capitaneum Lovicensem ${ }^{-\mathrm{bh}}$ bi- pro tempore existentem laicum a prima fundacione ecclesie predicte et ex consuetudine spectat et pertinet, ideo eciam ius patronatus dicti archidiaconatus capitaneo Lovicensi -bi laico totaliter reservamus, damus et concedimus perpetuo bs volentes et decernentes, ut tempore vacacionis archidiaconatus predicti ad ipsum personam idoneam nobis vel successoribus nostris presentet de eodem instituendam ${ }^{\mathrm{bk}}$. Cum autem ecclesiam parochialem predictam in Zduny per cessum vel decessum dicti Laurencii vacare et quempiam ad dictum archidiaconatum Lovicensem sic per nos, ut prefertur, in dictis canonicatu et prebenda Lovicensibus $^{\text {bl }}$ ac proventibus supra descriptis dicte parochialis in Zduny erectum $^{\text {bl }}$ presentari $^{\text {bm- }}$ per dictum $^{-b m}$ capitaneum Lovicensem laicum, et per nos seu successores nostros, vel per alium quemcunque a nobis seu successoribus nostris potestatem habentem institui et investiri. Sicque bn- investitum et institutum ${ }^{-\mathrm{bn}}$ archidiaconum possessionem dictorum proventuum ${ }^{\text {bo- }}$ et loci $\mathrm{ac}^{-\mathrm{bo}}$ in Ecclesia predicta Lovicensi, eciam adhuc ${ }^{\text {bp }}$ canonicatu et prebenda et aliis iuribus ${ }^{b q}$ predictis non assecutis contigerit. Volumus, ut idem ipse archidiaconus Lovicensis, br-qui pro tempore-br fuerit, cui ius patronatus dicte parochialis in Zduny vacacione ${ }^{\text {bs }}$ eius tociens quociens occurrenti ${ }^{\text {bt }}$ contulimus, conferimus et damus ${ }^{\text {bu }}$ per presentes perpetue, personam idoneam nobis et successoribus nostris presentet de eadem ad ${ }^{\text {bv }}$ vicarium perpetuum instituendum. Cui quidem vicario perpetuo pro tempore existenti curam animarum et ${ }^{b w}-$ administracionem sacramentorum $^{- \text {bw }}$ ecclesie parochialis predicte in Zduny, ac regimen et gubernacionem proventuum temporalium, preter decimas et alios proventus archidiacono Lovicensi incorporatas ${ }^{\mathrm{bx}}$ et assignatas ${ }^{\mathrm{by}} \mathrm{bz}-$ incorporatosque et assignatos $^{-b z}$ committimus temporibus perpetuis. In cuius rei testimonium nostrum et dicti Capituli nostri Gneznensis sigilla presentibus sunt appen-

\footnotetext{
bd quam kop. 2 be cum wyd. bf ecclesiae kop. 2 bg-bg predicta ecclesia wyd. bh-bh Capitaneo Loviciensi wyd. bi-bl brak kop. 1, wyd. bj perpetue kop. 2 bk instituendo $w y d$. bl Lovicensi kop. 1 bI creatum kop. 2 $\mathrm{bm}-\mathrm{bm}$ praedictum kop. 2 bn-bn constitutum et investitum wyd. bo-bo ac loci et $w y d$. bp adne kop. 2 bq viribus kop. 2 br-br pro quo tempore kop. 1 , wyd. bs vacacionem kop. 1 bt occurerit kop. 2, occurrente wyd. bu donamus kop. 2 bv ut kop. 1-2, wyd. bw-bw sacramentorum administracionem $w y d . \quad \mathrm{bx}$ incorporatos $w y d . \quad$ by assignatos $w y d . \quad \mathrm{bz}-\mathrm{bz}$ brak wyd.
} 
sa ${ }^{\text {ca }}$. Actum et datum Gnezne in capitulo generali pro festo Natalis sancti Adalberti celebrato ${ }^{15}$ anno Domini millesimo quingentesimo vigesimo secundo, indicione decima pontificatusque ${ }^{\mathrm{cb}}$ assumpcionis ad apicem summi ${ }^{\text {cc }}$ apostolatus sanctissimi in Christo partis et ${ }^{\text {cd }}$ domini, domini Adriani ce divina providencia electi episcopi Dertusensis ${ }^{23}$. Presentibus ibidem ${ }^{\text {cf }}$ venerabilibus dominis: Ioanne de Lassko ${ }^{c g}$ decano ${ }^{24}$, Spythkone Buzenski Gneznensi ${ }^{\text {ch }}$, Cracoviensi et ${ }^{\text {ci }}$ Lovicensi $^{\text {cj }}$ cancellarioque nostro ${ }^{25}$, Georgio $\mathrm{My}-$ skowski ${ }^{26}$, Mathia ${ }^{\text {ck }}$ Slywnyczski ${ }^{27}$ iuris utriusque doctoribus, Gneznensi-

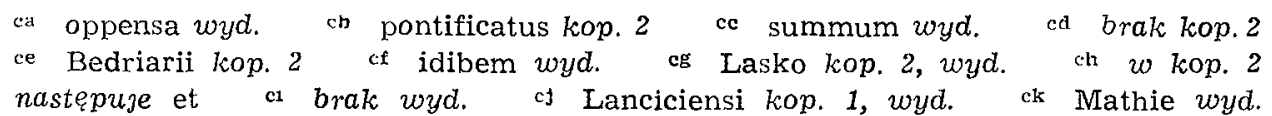

${ }_{23}$ Pap. Hadrian VI $z$ pochodzenıa Flandryjczyk, poprz. bıskup Tortozy w Hiszpanii, rządzit Koścıołem w l. 1522-1523.

24 Jan $z$ Lasku, Laski 1499-1560 h. Korab, bratanek arcybiskupa; stzdiowal $w$ Bolonii, Padwre i Rzymie 1514-1519; kustosz kęzycki, kanonik krakowski i plocki (potem kustosz) 1517; wyświęcony na kaptana i dzıekan gnieźnieński 1521, sekretarz król. 1522. Odwiedzit w Wittenberdze Lutra 1518, w Bazylei Erazma 1523 (od którego zakupit księgozbiór), w Zurychu Zwingliego 1524, przystając duchowo do reformacji. Wyrzekt sie neszczerze herezji, otrzymujqc od stryja prepozyturę gnieźnieńcka $i$ tęczycka 1526. Zaciagną się ( $z$ bratem Jarosławem) na służbę polityczna króla węg. Zapolyi i oddal sie nowatorstwu 1526-1539. Wikariusz kapitulny gnieźnieński 1531, archidiakon warszawski 1538; zabiegat $z$ rodzina $i$ stryjem dla siebie o biskupstwo plockie 1522, arcybiskupstwo gnieźn. 1526-1531; król był gotów dać mu wlocławskie 1530, poznańskie 1539, od Zapolyi otrzymaz weszpremskie 1530. Zerwał z Kościołem 2 przystapit do kalwinizmu 1540; w celu ratowania utraconych beneficjów wrócil do kraju $i$ powtórne falszywie odprzysięgat się apostazji 1542. Superintendent ewangelıcki $w$ róznych miastach Niderlandów, Niemiec, Danii i Anglii 1541-1556, zapraszany przez nee i usuwany. Wróciwszy na stale do Polski 1556, do śmierci szerzyt tu kalwinızm (Estreicher: Bibliografia, t. XXI, s. 83-90.- N. Korbut, 2, s. 484-489.- Łętowski: Katalog, t. III, s. 287-290.-Korytkowski: Pratact, t. II, s. 499-515-O. Bartel: Jan Łaskı, Warszawa 1955.- H. Kowalska: Dziatalność reformatorska Jana Łaskiego $w$ Polsce 1556-1560, Wroclaw 1969.- PSB (H. Kowalska), t. XVIII (1973), s. 237-244.-Hajdukıewıcz: Historia, s. 374-375).

$25 \quad$ Spytek Buzeński — zob. nr 16, przyp. 11.

26 Jerzy Myszkowski ( $z$ Przeciszewa na ter. par. Zagroba $w$ diec. plockiej) $h$. Jastrzębiec, dr ob. prawa, pleban par. Godzıanów $w$ dek. skierniewickım przed $r .1517$ $i$ par. Zator do 1529; kanonik gneźnieński i kanclerz kurii arcybpa Łaskiego 1517 oraz członek jego poselstwa do pap. Klemensa VII 1524, kanonik krakowski 1528, tamt. archıdiakon 1533; sekretarz król. 1506, wikariusz kapit. krakowski 1535; zasiużony prawnik, pragnący zostać biskupem, zm. 1543 (Łętowski: Katalog, t. III. s. 356-357.Korytkowski: Prałaci, t. III, s. 65-67.-Kurasiowa: Kancelaria, s. 143-144, nr 115).

27 Maciej Sliwnicki h. Korab studiowat w Krakowie, Bolonii 1514-1517 i Rzymie 1517-1519 uzyskujac doktórat ob. prawa; notarusz publ. 1510, odbywał praktykę w Konsystorzu Krakowskim i Rzymskım. Kanonik gnieźnieński 1519, archidiakon kaliski przed 1521, gnieźnieński 1528, poznański 1541, prowadzit spór $z$ wynikiem neg. o dziekanię gnieźn. z Janem Witkowskim 1535-1538; kanclerz arcybpa Łaskiego, sekretarz król. 1535, prepozyt poznański 1542, zm. 1551. Opisal dochody beneficjów archidiak. kaliskiego ok. 1521, należat po 1526 do komisji kodyfikacyjnej prawa miej- 
bus, Ioanne Zyrnyczski Lovicensis ${ }^{28}$, Venceslao Czyrka de Volkovysko ${ }^{\mathrm{cl}}$ Vylnensis ${ }^{29}$, Alberto Szyemykowski Vyelunensis ${ }^{\text {c130 }}$ ecclesiarum canonicis, Troiano preposito in Iwanowicze ${ }^{31}$ et Mathia ${ }^{\mathrm{cm}}$ de Calyenycze ${ }^{\mathrm{cn}}$ decretorum doctore, plebano in Ossyek ${ }^{32}$, capellanis nostris, aliisque multis testibus circa premissa.

co- Et ego Ioannes Alberti de Zyrnyki clericus Poznaniensis Diocesis, sacra apostolica auctoritate notarius publicus et coram memorato reverendissimo in Christo patre domino Ioanne Dei gracia Sancte Ecclesie Gneznensis archiepiscopo, legato nato et primate causarum et facti eiusmodi presentis scriba ${ }^{33}$; quia predictis omnibus et singulis premissis, dum sic, ut premittitur, agerentur et fierent, una cum prenominatis testibus presens interfui, omniaque ea et singula premissa sic fieri vidi et audivi; ideo presens publicum erectionis archidiaconatus instrumentum, manu alterius notarii (me presente aliis arduis occupato negociis) fideliter scriptum, exinde confeci et in hanc publicam formam redegi, sig-

cl Volkovyko kop. 1, Volkorzysko wyd. ck Vylnensis kop. 1 cm brak kop. 1, wyd. cn Calyenyc kop. 1, Kalyenyc kop. 2, Calenicze wyd. co-co brak kop. skiego (Liber beneficiorum, t. II, s. IV, V, VI.- Korytkowski: Pralaci, t. III, s. 527537.- J. Dworzaczkowa: Z historii projektu kodyfikacji M. Sliwnickiego, „Czas. praw.-hist.", t. 6: 1954, s. 178-183.- Hajdukıewncz: Historia, s. 683-684).

28 Jan $z$ Żernik (miejscowości kościelnej $w$ dek. rogowskim) Żernicki h. Dryja, notariusz publ. $z$ ust. pap. i kurii zadwornej prymasa Laskiego ok. 1511, pleban par. Jankowo (obec. wieś w par. Strzyżewo dek. gnieźn.) ok. 1517, kanonik lęczycki 1511, towicki ok. 1522-1526, gniezniensski od 1526. Z kan. gnieźn. Szymonem z Lesniewa porzadkowat archiwum tamt. kapituly 1527; przeprowadzit rewizję jej majatków 1534. Pobity przez szl. Piotra Pepowsikiego w 1540, żyt w kalectwie do 1553 (Liber beneficiorum, t. I, s. 102.- Korytkowski: Prataci, t. IV, s. 504-507.- Wizytacje dóbr, s. 861 (indeks).-Wiete ka: Katalog, s. 37-38).

29 Waclaw Czyrka (Cirka) z Wolkowyska $w$ diec. wileńskiej, dr prawa kan., notarıusz publ. $z$ ust. pap. $\imath$ w kancelarii Łaskiego, kanonik wilenskı przed 1522, towicki ok. 1524, tamt. kustosz 1529 (Wieteska: Katalog, s. 38).

30 Wojciech Siemikowski ( $z$ Siemkowic, daw. Siemikowice) h. Oksza, pleban par. Borszewice $w$ dek. taskim i kanonik wieluński ok. 1522, kanonik gnieźnieński 1540, tamt. kanclerz $1547 i$ scholastyk przed 1558. Byt agentem $w$ Rzymıe $z$ ramienia kilku biskupów pol., gdzie mał studiować, przyıać w 1550 święcenıa kapłańskie i umart w 1558 (Liber beneficiorum, t. II, s. 101.-Korytkow'ki: Pralaci, t. III, s. 488-489).

31 Jan Trojan ze Śleszyna, wsì kościelnej w dek. żychlińskim (Szleszyński) $h$. Wieniawa, dr prawa kan., kapelan arcybpa Łaskiego, prepozyt par. Iwanowice $i$ Łask ok. 1521, kanonik łęczycki, pierwszy prepozyt kapituty $w$ Easku od 1525. Ok. 1521 opisat dochody beneficjów w terytorium wieluńskim (Liber beneficiorum, $t$. $I, s .92$, 445-446; t. II, s. IV, VI, 92, 110).

32 Maciej z Kalenı (wsi na ter. par. Pszczonów w dek. łowrckim Sw. Ducha) dr prawa kan., pleban par. Osiek w dek. kolskım, gdzie wspótcz. nazywano go Mazowszaninem, kapelan prymasa Łaskiego ok. 1521-1522 (Liber beneficiorum, $t$. I, s. 220$)$.

s3 Zob. przyp. 28. 
noque et nomine meis solitis et consuetis una cum sigilli dicti reverendissimi domini archiepiscopi de sue paternitatis mandato appensione consignavi in fidem et testimonium omnium et singulorum premissorum, rogatus et requisitus quando idem ${ }^{\mathrm{cp}}$ privilegium ita subscriptum erat $^{-c o}$.

cq- Transivit per manus mei Ioannis Lathalski prepositi Gneznen$\operatorname{sis}^{-\mathrm{cq} 34}$.

Lowicz, po 22 lipca 1523

Kapitula lowicka, na polecenie arcybiskupa Jana Laskiego, sporzadza kopie 21 ważniejszych swoich dokumentów z lat 1433-1519. Ostatnia, nie numerowana pozycje (bylby to $n r$ XXII) stanowi skrócony opis dochodów prebend pralackich $i$ kanonickich tejże kapituly. Dokumentacje owq zamieszczono $w$ Liber beneficiorum Laskiego, na końcu opisów archidiakonatu lęczyckiego.

Or. (czyst.): AAG: Liber beneficiorum, rps.

Kop. 1. Widymat wyd. 17 czerwca $1747 \mathrm{r}$. kapitula low. przez kapitule metrop. gnieżn. na podstawie or., nie zachowany (Kopıariusz Janickiego, s. 69.- Kopiarususz Sladeckiego, s. 220).

2. AAW: Kopıariusz Janickıego z r. 1749, s. 20-69.

3. AKŁ: Kopiariusz Sladecktego sprzed r. 1810, s. 202-220, przed s. 202 $\imath$ po 220.

Wyd. Liber beneficiorum, t. II, s. 507-552.

Reg. Librowski: Sumariusz, $n r$ 39, 45.

Uw. 1. Tytul we wszystkich przekazach: Inventarius Ecclesie Collegiate Sancte Marie Lovicensis ad mandatum et compulsum reverendissimi in Christo patris domini et domini Ioannis Dei gracia Sancte Ecclesie Gneznensis archiepiscopi, legati nati et primatis, extractus quantum ad privilegia, donaciones omnes et singulas, universaliter et generaliter, specialiter tamen ad fundum uniuscuiusque

1, wyd. $\quad \mathrm{cp}$ quidem kop. 2 cq-cq per manus reverendi patris et domini Ioannis Lathalski prepositi Gneznensis, Cracoviensis et Lanciciensis Ecclesiarum transivit kop. 1; $w$ wyd. zamiast Cracoviensis: Posnaniensis $i$ brak stowa transivit.

34 Jan z Latalic (wsi $w$ par. Weglewo dek. pobiedziskiego) Latalski h. Prawdzac,

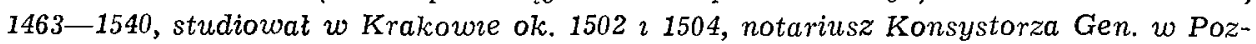
nanıu ok. 1488, sekretarz król. przed 1492, sekretarz w. przed 1524, kanclerz kr. Elżbiety 1498-1507. Kanonik poznański 1495, tamt. prepozyt 1523, prepozyt gnieźnieński 1500, krakowski 1503, lęczycki 1506. Biskup poznański 1525, krakowski 1536, arcybiskup gnieźn. i prymas 1537. Czynny na polu kościelnym i politycznym, mecenas (Estreicher: Bibliografia, t. XXI, s. 329.- Łętowski: Katalog, t. II, s. 95-100.- Korytkowskl: Arcybiskupi, t. III, s. 45-80; t. V, s. 323.- Szostkiewicz: Katalog, s. 107.- Nowacki: Archidiecezja, t. II, s. 91-92_- Kurasiowa: Kancelaria, s. 137, nr 94.- PSB (I. Sutkowska-Kurasiowa), t. XVI (1971), s. 562-563.- Hajdukiewicz: Historia, s. 348-349). 
prelati et canonici, secundum quod continent in erectione et privilegio fundatoris et aliorum reverendissimorum dominorum, qui donaverunt certis dotibus, decimis ipsam Ecclesiam Lovicensem et ipsos prelatos et canonicos, ut patet ex privilegiis suarum paternitatum, necnon censibus, proventibus, emolumentis omnibus et singulis iuxta paternitatis sue reverendissime mandatum editum sub anno Domini millesimo quingentesimo vicesimo tercio, die vicesima secunda Iulii.

2. Por. $n r 17$.

Jan arcybiskup gnieźnieński, prymas i legat urodzony zmienia $w$ dwóch istotnych sprawach treść dokumentu erekcyjnego archidiakonatu lowickiego z kwietnia 1522 r. Po pierwsze - na prośby duchowieństwa dekanatu bedlneńskiego, a za zgoda obydwu archidiak.: lęcz. F. Naropińskiego $i$ low. Wawrzyńca z Powidza oraz kapituly metrop. gnieźnieńskiej - przywraca wspom. dekanat archidiakonatowi Łęczyckiemu. Po wtóre - proszony przez wikariusza wiecz. par. (archidiakońskiej) Zduny Grzegorza ze Slupcy, a za przyzwoleniem archidiak. low. Wawrzyńca $z$ Powidza i kapituly gnieźn. powiększa uposażenie tegoż wikariusza. We wszystkich innych punktach zasadniczy dok. erekcyjny archidiak. lowickiego ma zachować swoja poprzednia moc.-Dokument spisal $w$ formie instrumentu notarialnego Waclaw Czyrka z Wolkowyska not. publ.

Or. nie znany.

Kop. AKE: Kopiariusz Sladeckiego sprzed r. 1810, s. 244-249. Tytut: 1528. Erectionis Archidiaconatus Loviciensis reformatio.

Reg. Librowski: Sumariusz, $n r 50$.

Lit. J. Witeska: Archidiakonat, jak w nrze 5, s. 74.

Uw. Por. $n r 18$.

In nomine Domini amen. Ad rei memoriam sempiternam. Nos Ioannes de Lasko Dei et Apostolice Sedis gracia archiepiscopus Gneznensis, primas legatusque natus ${ }^{1}$. Significamus tenore presencium, quibus expedit, universis presentibus et futuris harum noticiam habituris. Quomodo cum aliquanto ante tempore, de consilio et consensu fratrum nostrorum prelatorum et canonicorum tam nostre Gneznensis Metropolitane, quam Lanciciensis et Lovicensis Collegiatarum Ecclesiarum, archidiaconalem dignitatem in Ecclesia predicta Lovicensi in decimis et proventibus canonicatus et prebende Lovicensis, quorum venerabilis olim Stanislaus de Zawady tunc possessor extiterat 2 , necnon in decimis manipularibus villarum utraque Jaczkowy-

20. I Jan Laski arcybiskup - zob. nr 14, przyp. 1.

2 Stanistaw $z$ Zawady lub $z$ Zawad - zob. nr 18, przyp. 5. 
cze $^{3}$, Jaszyona ${ }^{4}$, Strugyenycze ${ }^{5}$ de advocatorum agris et in Wrzecze ${ }^{6}$ de agris predialibus, certis colonis ibidem locari solitis, missalibus in Laszny$\mathrm{ki}^{7}$, Zduny ${ }^{8}$, Strugyenycze, a parochiali ecclesia in Zduny, cuius Laurencius de Powydz tunc possessor fuerat ${ }^{9}$, separatis et dismembratis ac eidem archidiaconali dignitati una cum iurisdicione archidiaconali duorum decanatuum ruralium Ravensis ${ }^{\mathbf{1 0}}$ et Bedlnensis ${ }^{11}$, ab Archidiaconatu Lanciciensi similiter [s. 245] separata atque dismembrata, unitis et incorporatis, de venerabilis domini Felicis Naropyenski archidiaconi Lanciciensis moderni ${ }^{12}$, ac Stanislai de Zawady et Laurencii de Powydz possessorum predictorum a consensu expresso, crida legitime premissa, nemine contradicente, creaveramus, fundaveramus et erexeramus, cum certis ordinacionibus et decretis cultum divinum et regimen cure pastoralis concernentibus non improbandis, prout hec in literis patentibus erectionis nostre, nostro et Venerabilis Capituli Gneznensis sigillo consignatis, de data Gnesne in capitulo generali Natalis divi Adalberti patroni nostri de anno Domini millesimo quingentesimo vigesimo secundo confectis lacius continetur ${ }^{13}$. Sed quoniam inter homines nihil est adeo indubitatum, quin non posset, licet id sit admodum iustum, successu temporis suscipere quandam solicitam dubitacionem, unde evenit, quod licet creacio et erectio dignitatis archidiaconalis predicte cum dismembracionibus, unionibus, annexionibus et incorporacionibus suis nobis, dum in esse deducebantur, vise fuerant ex omni parte nemini onerose atque iuxta formam iuris confecte, nihilominus postea ex certis causis reformacione plurima in punctis et articulis infrascriptis egere videbantur. Siquidem clerus universus Decanatus ruralis Bedlnensis et honorabilis Gregorgius de Slupcza vicarius perpetuus ecclesie parochialis in Zduny ${ }^{14}$, per nos vigore erectionis et dismembracionis predictarum de novo creatus et institutus, sua nobis insinuacione monstraverit, qualiter, dum in Ecclesia Lovicensi Collegiata sinodi archidiaconales ${ }^{15}$ et contribuciones ecclesiastice

\footnotetext{
20. a praelatorum kop. $b-b$ deferre et censum officialis Lanciciensis kop.

3 Jackowice, wieś - zob. nr 18, przyp. 18.

4 Jasionna, wieś - zob. nr 18, przyp. 19.

$5 \quad$ Strugienice, wieś - zob. nr 18, przyp. 20.

- Urzecze, wieś - zob. nr 18, przyp. 21.

7 Eazniki, wieś - zob. nr 18, przyp. 22.

8 Zduny, wieś kościelna - zob. nr 18, przyp. 6.

$9 \quad$ Wawrzyniec $z$ Powidza - zob. nr 14, przyp. 13.

10 Dekanat (wiejski) rawski - zob. nr 18, przyp. 11.

11 Dekanat (wiejski) bedlneński - zob. nr 18, przyp. 12.

12 Feliks Naropıński - zob. nr 18, przyp. 10.

13 Por. dokument nr 18.

14 Grzegorz z miasta Siupcy lub wsi Stupia, do r. 1522 pleban par. Błonie $w$ dek. tęczyckim, poźniej wikariusz wiecz. par. Zduny (Liber beneficiorum, $t$. II, s. 432).

15 Mowa o synodach archidiakonalnych, czqstkowych $w$ archidiecezji gnieznien-
} skiej. 
in provincionalibus sinodis per nos pro tempore indicuntur et decernuntur, plebani et clerus universus predicti decanatus de [s. 246] locis remocioribus, eciam intra Lanciciam constitutis ${ }^{16}$, Lovicium ad sinodos venire, contribuciones deferre et processibus officialis nostri Lovicensis propterea parcere ${ }^{17}$ cogerentur, cum tum cum commoditate moliore Lanciciam, qui locus propinquior est, venire, ${ }^{b-}$ censum deferre et officiali Lanciciensi ${ }^{-b}$ parere possent, prout ante dismembracionem per nos factam venire, deferre et parere consueverant. Prefatus vero vicarius perpetuus in Zduny vigore erectionis et dismembracionis predictarum fuerat in annuis proventibus usque adeo extenuatus, quod victum et amictum oompetentes ex fructibus infrascriptis, sibi et suis successoribus resignatis, habere non valeret. Volentes igitur more boni pastoris commoditatibus et utilitatibus cleri nostri ex omni parte benigne succurrere et ordinaciones tempore felicis presidencie nostre factas, ne ab aliis reformentur, nos ipsi in melius emendare, Decanatum ruralem Bedlnensem $a b^{c}$ Archidiaconatu Lovicensi ex causis predictis separandum et dismembrandum, ac Archidiaconatui Lanciciensi cum eius iurisdicione anteriori uniendum, annectendum, incorporandum et restituendum duximus, prout de consensu expresso venerabilium dominorum Felicis Naropyenski archidiaconi Lanoiciensis predicti et Laurencii de Powydz decretorum doctoris, archidiaconi Lovicensis moderni separamus, dismembramus, unimus, annectimus, incorporamus et restituimus perpetuo et in evum, sub ratihabicione venerabilium fratrum nostrorum prelatorum et canonicorum Ecclesie nostre Metropolitane Gneznensis ${ }^{18}$, tenore presencium mediante. Et quoniam venerabilis Laurencius de Powydz, ante erectionem dignitatis archidiaconalis existens rector et possessor pacificus ecclesie [s. 247] parochialis in Zduny, consenserat non gravatim in dismembracionem et separacionem decimarum et missalium superius descriptarum, ideo volentes eundem pro tam pio et laudabili opere facere consolatum, et ne pro benefactis dispendia sentire videatur, decimas villarum predictarum, videlicet Jaczkowycze utraque de araturis colonorum tantum et Jaszyona, necnon missalia in Lasznyki iuxta tenorem erectionis sibi et successoribus suis archidiaconis Lovicensibus; reliquas autem decimas in literis erectionis contentas, videlicet in Jaczkowycze prediali, in Strugyenycze de araturis advocatorum, in Wrzecze de araturis predialibus, ibidem certis colonis lo-

\footnotetext{
c et abkop. a et vicario kop. e cum kop. 1 Slinowyczki kop. $\mathrm{g}$ Lopathynszki kop. in domine kop. I Martinus kop.
}

16 Wprawdzie samo miasto Łęczyca nalezalo do dek. szczawińskzego, który po r. 1522 pozostat $w$ archidiakonacıe tęczyckim (Liber beneficiorum, t. II, s. 348), ale juz sqsiednie parafie: Kościól (Tum) $i$ Topola, znajdujqce się $w$ dek. bedlneńskim (tamże, s. 429), zostaty wtenczas przydzzelone do nowego archidiak. towickiego.

$17 \mathrm{Z}$ kontekstu wynika, ze wbrew relacji dok. nr 18, tylko częśc dek. bedlneńskiego mogka wtedy nalezeć do oficjałatu towickrego.

18 Por nr 2, przyp. 8. 
cari solitis, necnon missalia in Zduny et Strugyenycze ad vitam suam tantum ex officio nostro reservandas et ascribendas duximus. Ipso vero ex humanis decedente prefatas decimas et missalia, ad vitam eius Laurencii archidiaconi reservatas, una cum decimis in Zduny prediali et de araturis advocatorum, in Marzicze ${ }^{19}$ similiter de araturis advocatorum et in Lasznyki pecuniaria, eciam de araturis advocatorum, una cum columbacione ex omnibus et singulis villis prefatis provenientibus predicto Gregorio vicario d perpetuo in Zduny et suis ${ }^{e}$ successoribus vicariis, sub ratihabicione similiter et oonsensu venerabilium fratrum nostrorum prelatorum et canonicorum Ecclesie Gnezensis ${ }^{18}$, reservamus, ascribimus, unimus, appropriamus, restituendum et incorporandum duximus; prout reformamus, ascribimus, unimus, appropriamus, restituimus et incorporamus tenore presencium mediante perpetuo et in evum. Literis erectionis predicte, quoad premissa non obstante, quas in hac parte iure et iusticia suadente moderamur, sed volumus nihilominus et decernimus, quod omnia [s. 248] alia et singula in dictis literis nostre erectionis robur obtineant perpetue firmitatis, quibus propter ordinacionem, restitucionem et incorporacionem predictas nolumus aliquatenus derogari harum, quibus sigillum nostrum est subappensum, testimonio literarum. Actum et datum in castro nostro Lovicensi anno a Nativitate Domini millesimo quingentesimo vigesimo octavo, indicione prima, pontificatus sanctissimi in Christo patris et domini nostri, domini Clementis divina providencia pape septimi anno quinto ${ }^{20}$, die vero nona mensis Aprilis. Presentibus ibidem venerabilibus dominis: Ioanne Iaroslai de Lasko Gneznensi et Lanciciensi preposito, custode Plocensi, canonico Cracoviensi et secretario regio ${ }^{21}$, Mathia Slywnyczski ${ }^{\mathrm{I}}$ iuris utriusque doctore, Gneznensi et Calissiensi archidiacono, cancellario nostro ${ }^{22}$, Mathia Loboczki cancellario et capitaneo Lovicensi ${ }^{23}$, Stanislao Czasznyczski decano Lovicensi et economo nostro ${ }^{24}$ et Martino Lopateczski ${ }^{825}$ Metropolitane Gneznensis;

19 Maurzyce, wieś na ter. par. Zduny w dek. lowickım kolegıaty (Rocznik 1958, s. 310.- Waręak: Stownik, z.'1, s. 246-249.-Zajaczkowscy: Materiazy, cz. I, s. 195).

20 Pap. Klemens VII rzqdził Koścrolem $w$ l. 1523-1534.

21 Jan Easki apostata - zob. nr 18, przyp. 24.

$22 \quad$ Maciej Sliwnıcki - zob. nr 18, przyp. 27.

${ }_{23}$ Macıej Łobockı (Łobodzki) h. Jastrzębıec, siostrzeniec arcybıskupa, studiowat $w$ Krakowie $w 1511$ i 1515 oraz $w$ Rzymie. Kanonik poznanski $w 1508$, archidiakon gnezzneńsk 1517 i powtórnie 1525, $z$ któreł to prałatury ponownı zrezygnowal 1528, dzıekan łęczycki, kanclerz gnieźn. i starosta lowickı prym. Łaskıego w 1528, zm. po. 1529 (Korytkowski: Prataci, t. II, s. 526-527).

24 Stanısław Czaśnıcki akt. dziekan zowicki, pewnie od 1507, kanonik gnieźnıenski 2 gen. ekonom dóbr arcybiskupstwa, scholastyk gnieźn. ok. 1535.- Łętowskı (Ka-. talog, t. II, s. 160) posiada tylko Stanısława Czaszyńskiego, podobnie Wieteska (Katalog, s. 36) - Stanisława Czasznickıgo. Korytkowski (Pralacı, t. I) siusznie rozróznia dwóch kanoników: Stanisława Czaśnickıego (s. 162-163) I Stanısława Czaszyñskiego (s. 163), ale, nestety, miesza ich chronologię 2 stanowiska. 
Iacobo de Cracovia arcium et medicine doctore, Lanciciensi et Lovicensi, physico nostro ${ }^{26}$ et Mathia Pierzynski Unieioviensi ${ }^{27}$ canonicis, et aliis quam plurimis ad premissa testibus vocatis, pariter atque rogatis.

Et ego Venceslaus Czyrka de Wolkowysko clericus Vylnensis Diocesis, sacra auctoritate apostolica publicus et in Archivo Curie Romane descriptus et matriculatus notarius, ac coram memorato reverendissimo in Christo patre domino ${ }^{\text {h }}$ Ioanne Dei gracia archiepiscopo Gneznensi causarum et facti huiusmodi scriba ${ }^{28}$; quia premissis omnibus una cum testibus antedictis presens interfui et, dum sic fierent et agerentur, vidi et audivi; ideo presentes literas, per alium fidelem notarium scriptas, manu mea propria subscripsi, signoque et nomine meis solitis [s. 249] et circa talia fieri consuetis, una cum dicti reverendissimi domini Ioannis de Lasko archiepiscopi Gneznensis, primatis et legati nati sigilli legitima appensione consignavi et communivi, in fidem et testimonium maius omnium et singulorum premissorum rogatus, pariter et requisitus.

Transivit per manus Mathie Slywnyczski ${ }^{\mathfrak{i}}$ iuris utriusque doctoris, archidiaconi Gneznensis in absencia cancellarii ${ }^{29}$.

Mathias ${ }^{2}$, qui supra ${ }^{30}$, signavit.

Ok. 13 listopada 1528

Jan Laski arcybiskup gnieźnieński, prymas i legat urodzony eryguje $w$ kolegiacie i kapitule towickiej kanonikat, którego glówne uposażenie będzie pochodzilo $z$ inkorporowanej mu tymże aktem parafii Slupia.

Or. nie znany.

Wp. W zniszczonych $w$ r. 1944 aktach arcybpa Easkiego pod dn. 13 XI 1528 (Regesty zapisek, s. 39); dlatego nie znamy miejsca $i$ daty jego wystawienia.

Uw. 1. Par. Stupia wtenczas $w$ dek. rawskim. dzisiaj $w$ skierniewickim.

25 Marcin Łopatecki h. Korab, krewny prym. Easkiego, pleban par. Sędziejowice $w$ dek. Zaskım, kanonik gnieźnieński od 1525, pleban par. Parlin $w$ dek. Mogilno 1539. W r. 1543 przeprowadzit wizytację majątków kapituty metrop. gneźn., zm. w 1580 (Korytkowski: Prałaci, t. II, s. 527-528).

28 Jakub z Krakowa - zob. nr 16, przyp. 16 .

27 Maciej Pierzyński akt. kanonik kolegiaty uniejowskiej.

28 Wacław Czyrka - zob. nr 18, przyp. 29.

28 Mowa o Macieju Łobockim kanclerzu kapituły gnieźnieńskiej.

30 Pratat Sliwnicki (wyzej przyp. 22) albo posiadat drugie imię Marcin, albo też $w$ dokumentacji o nim odnośnie imienia zachodzi pomyłka (Korytkowski: Prałaci, t. III, s. 537). 
2. Kanonie te utworzyl Łaski przyp. $w$ miejsce kanonikatu fund. Duplice Wielkie (Duze), którego prebenda stała się w r. 1522 i 1528 jedna $z$ dwóch zasadniczych podstaw utrzymania nowej pratatury archidiakona.-Por. nr 18 i 20 .

3. Odnośnie tej kanonii nie natrafilem na żadna informację $w$ bogatych, jakkolwiek zachowanych dopiero od $r$. 1612, aktach kapituly $w$ Lowiczu.

\section{2}

Ok. 26 maja 1529

Jan Łaski arcybiskup gnieźnieński, prymas $i$ legat urodzony, albo te $\dot{z}$ upoważniony przez niego Wawrzyniec $z$ Powidza archidiakon $i$ oficjal lowicki eryguje $w$ kościele szpitalnym św. Jana Chrzciciela $w$ Łowiczu oltarz (i pewnie oltarię) pt. św. Doroty.

Or. nie znany.

Wp. W zniszczonych $w$ r. 1944 aktach Konsystorza For. Łowickiego pod dn. $26 \mathrm{~V} 1529$ (Regesty zapisek, s. 16); z tego powodu miejsce i data wystawienia dok. nie sq znane.

Uw. 1. Wawrzyniec $z$ Powidza byt oficjalem tow. przyp. w l. 1527-1532 (Acta capitulorum et iudiciorum, t. II, s. VIII, 385, nr 808).

2. Kościót św. Jana stanowit prepozyturę zwykta od $r .1433$ (nr 5, przyp. 74), atoli istnaal $w$ Łowiczu przynajmniej od 2 pot. XIV $w$. (nr 2, przyp. 20).Sw. Dorota (zob. nr 8, przyp. 16) byla gtównq patronkq tego ottarza, ale - zwyczajem średniowiecznym - nie jedynq.

\section{3}

Ok. 10 czerwea 1530

Jan Laski arcybiskup gnieźnieński, prymas $i$ legat urodzony wciela do uposażenia kolegium wikariuszy kolegiaty lowickiej kościól parafialny $w$ Kocierzewie.

Or. nie znany.

Wp. Akta Konsystorza For. Eowzckiego, zniszczone w r. 1944, pod dn. $10 \mathrm{VI}$ 1530 (Regesty zapisek, s. 17); z tej przyczyny nie wiemy o miejscu $i$ dacie wystawienia dokumentu.

Uw. 1. Opis pierwotnego uposażenıa kol. wikariuszy 2 mansjonarzy lowickich znajduje się $w$ jego dok. erekcyjnym $z$ r. 1467 (nr 9).

2. Pir. Kocıerzew lezala wtedy $w$ dek. rawskim, obecnie zaś $w$ townckim kolegiaty.

3. Ks. Korytkowski, który redagowat przypisy do wyd. Liber beneficiorum, informuje błęd. (tamże, t. II, s. 261), ze parafia ta zostaka inkorporowana wspom. wikariuszom dopeero $w$ XVII $w$.

4. Na skutek wlqczenia Kocierzewa do mensy wikarnuszów, wym. parafia weszła do „wrelkiej" rodziny beneficiów kolegiaty zow. To było powodem, że wikarısze townccy przynieśli $24 \times 1668$ dokumenty par. Kocierzew do ingrosacji w akta arcybpa Prażmowskiego (Regesty zapisek, s. 169). 3 VII 1771 uzyskali 
oni od kapituly metrop. gnieźnieńskiej wierz. kopię opisu uposażenia wspom. parafii $z$ Liber beneficiorum, którq $z$ kolei 23 VII 1791 dostarczyli do wciqgnięcia $w$ akta prym. Poniatowskiego (Kopiariusz Sledeckiego, s. 158-163.- Regesty zapisek, s. 285.- Librowski: Sumariusz, nr 35). Druk tegoz $w$ Liber beneficiorum, $t$. II, s. $260-263$.

5. W jednym z kopiariuszy gneźnieńskich wyczytatem, że arcybp Easki wydany przez siebie dla koścrelnego ośrodka lowickiego dokument polecit tamt. kapitule wciqgnać do akt Konsystorza Łow. Inn ordynarnusze też stosowali owa praktyke. Dlatego o nin. dokumencie $i$ o przedstawionym $w$ nrze 22 wiemy $z$ akt konsystorskich, a nie z arcybiskupich.

(Lowicz) 27 stycznia 1550

Michal notariusz Konsystorza Lowickiego stwierdza, że Hieronim Gawroński oficjal tegoż konsystorza, upoważniony przez arcybiskupa Mikolaja (Dzierzgowskiego) - na prośbe Jana wiceprepozyta tamt. kolegiaty, dzialajacego w imieniu miejsc. kapituly, patrona ottarza, o którym niżej mowa, przy braku sprzeciwu osób ewent. tym zainteresowanych - przenosi ottarz (i oltarię) pt. Matki Bożej Różańcowej z kościola parafialnego w Zlakowie, ze wszystkimi jego obowiazkami i uprawnieniami, do kolegiaty lowickiej.

Wp. pod dn. 5 II 1552 do akt Konsystorza For. $w$ Lowiczu, znisz. $w$ r. 1944 (Regesty zapisek, s. 25).

Kop. AKE: Kopiariusz Sladeckiego sprzed r. 1810, s. 290-292. Tytul: 1550. Transportatio Altaris tituli Rosarii B.V. Mariae ex Zlakow in Collegiatam Loviciensem. Odpis sporz. z wpisu lub jego wierz. kopii, nie znanej.

Reg. Librowski: Sumariusz, nr 55.

Uw. 1. Oltaria ta byta nowa, powstata po r. 1520, gdyz nie figuruje $w$ Liber beneficrorum (t. II, s. 258-260).

2. Przeniesienie tego oltarza nie musialo się odbyć $w$ znaczeniu fizycznym, ale prawnym, tzn. że pozostal on $w$ Zlakowie stając się nowym zamiejscowym beneficjum duchowieństwa kolegiaty lowickiej.

Anno Domini millesimo quingentesimo [quinquagesimo ${ }^{a}$ ], die vigesima septima Ianuarii. In causa commissoria ordinaria Venerabilis Capituli Ecclesie Collegiate Loviciensis altaris tituli Rosarii Gloriosissime Virginis Marie in ecclesia parochiali in Zlakow ${ }^{1}$ siti, legitimorum patronorum et collatorum ${ }^{2}$, honorabilis Ioannes viceprepositus et eiusdem capituli notarius ${ }^{3}$ ipsius

24. a brak $w$ kop. b scriptas kop. c sigillatas kop. a emanatas kop.

24. 1 Zlaków, wreś i par. w dek. lowickım kolegiaty (Rocznik 1958, s. 311).

2 Nie wradomo, $w$ jakı sposób kapituta towicka doszła do patronatu nad ottarzen $w$ Zlakowie, parafii kollacji arcybiskupiej (Liber beneficiorum, t. II, s. 258). Może $z$ tej racji, iz cztery jej kanonikaty $(7-10)$ czerpaly swe uposażenie $z$ dzlesięcin owej rozbudowanej wsi (tamże, s. 244-245, 511-Wyzej nr 5, przyp. 48-53).

8 Jan wiceprepozyt $\imath$ notarusz kapituty w Eowiczu. 
capituli nomine, presentatis literis citacionis in vim cride publicis, ex cancellaria reverendissimi in Christo patris et domini, domini Nicolai Dei gracia Sancte Ecclesie Metropolitane Gneznensis anchiepiscopi, legati nati et primatis ${ }^{4}$ contra omnes et singulos sua communiter vel divisim interesse ad hoc ipsum altare habere putantes, ad videndum et audiendum huiusmodi altare ex prefata ecclesia parochiali in Zlakow in Ecclesiam Collegiatam Loviciensem cum omnibus et singulis oneribus eidem altari annexis, eiusque omnibus proventibus et obvencionibus ad hoc ipsum altare quomodolibet concernentibus, ex certis causis et racionibus animum sue reverendissime paternitatis permoventibus, transferri, sub titulo sigilloque sue reverendissime paternitatis scriptis ${ }^{b}$ et sigillatis ${ }^{c}$, emanatis ${ }^{d}$ et debite, ut apponuntur, executis ${ }^{\mathrm{e}}$, una cum commissione in persona venerabilis ${ }^{\mathfrak{f}}{ }^{\text {[s. 291] }}$ domini Hieronymi Gawronski Gneznensis, Loviciensis canonici et officialis ${ }^{5}$ in eisdem inserta, obtentis [innatisque ${ }^{8}$ ] legitime, et non comparencium contumaciam accusavit et in eorum contumacia predictum altare ex prefata ecclesia parochiali in Zlakow in Ecclesiam Collegiata Loviciensem cum omnibus et singulis oneribus in altare annexis, eiusque omnibus proventibus et obvencionibus ad hoc ipsum altare quomodolibet concernentibus transferri ${ }^{h}$ [et transportari ${ }^{i}$ ], pratum et aream ad domiculam in Zlakow sita, pro altari prefato et eiusdem possessoribus altaristis per honorabilem olim dominum Ioannem de Zlakow eiusdem altaris immediatum possessorem $^{6}$ legata et donata, eidem altari perpetuo incorporanda et annectenda petiit et debita cum instancia postulavit. Et dominus legitime citatus et non comparens ${ }^{5}$, ac quicquam facere curantibus, contumacibus merito reputatis, iisdemque diucius intra horam audiencie solitam expectatis, in eorum contumaciam predictum altare ex dicta parochiali in Zlakow in Ecclesiam Collegiatam Loviciensem cum omnibus et singulis eiusdem omnibus pro-

\footnotetext{
e executas kop. $\quad$ f dwukrotnie w kop. $\quad$ g lekcja niepewna; in natoru kop. 4 Mikolaj $z$ Dzierzgowa (wsi kościelnes $w$ dek. przasnyskim) Dzierzgowski h. Jastrzęblec ok. 1490-1559, studiowal na Unıw. Krakowskim 1514 ? we Whoszech 1539; kanonik warszawskı 1514, notarıusz król. 1518 ? później sekretarz, kanonik płocki a potem dzzekan, wikarıusz kapitulny tejże diec. 1541. Biskup kamzeniecki 1541, chelmski 1542, wloclawski 1543, arcybiskup gnieźnieński i prymas 1546. Zaslużony

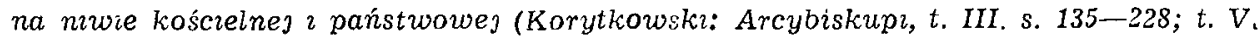
s. 295.- Fijalek: Ustalenıe, s. 68.- W. Pocıecha: Arcybp gnieźn. M. Dzierzgowski..., „Nasza Przeszl.", II: 1947, s. 37-102.- PSB (W. Pocrecha), VI (1948), s. 145-150.Szostkiewrcz: Katalog, s. 52).

5 Hieronım Gawroński h. Rawicz, kanonik gnięnneńskı z lowickı ok. 1550-1552, oficjal lowicki 1548-1557 (Regesty zapisek, s. 133-138.- Wieteska: Katalog, s. 41.Brak u Korytkowskiego (Pralaci, t. II).

- Jan ze Zlakowa ostatn kapelan nin. oltarza, a jak wynika $z$ dokumentu dobrodzıej swoich następców.
} 
ventibus et obvencionibus universis transtulit et transportavit; necnon aream, pratum et domiculam sic, ut premissum est, pro ipso altari et eius possessoribus legata et donata, eidem altari incorporavit et annectivit perpetuo et in evum pro ipso altari et eiusdem possessoribus ${ }^{j}$ tenenda, habenda et utifruenda. Literasque desuper necessarias et opportunas dandas decrevit et extradere mandavit ? Presentibus tunc honorabilibus: Luca organario, eiusdem altaris moderno possessore ${ }^{8}$, Stephano Glowno ${ }^{9}$ et Laurencio Stronyewicz ${ }^{10}$ lectoribus missarum Ecclesie Collegiate Loviciensis [s. 292] notariisque commissionis, et me Michaele actorum Consistorii [Loviciensis ${ }^{\mathrm{k}}$ ] notario ${ }^{11}$.

Ok. 6 listopada 1551

Mikolaj z Dzierzgowa (Dzierzgowski) arcybiskup metropolita gnieźnieński, legat urodzony $i$ prymas ${ }^{1}$ eryguje $w$ kolegiacie lowickiej oltarz (i oltarię) pt. Trójcy Swiętej oraz św. Jakuba ap. ${ }^{2} i$ św. Bernarda op. ${ }^{3}$, ufundowany (testamentalnie) przez Bernarda Pontificiusa (Biskupskiego) kanonika towickiego ${ }^{4}$ (któremu dopomógł w tym dziele brat Jakub Pontificius miejsc. archidiakon ${ }^{5}$.

Or. nie znany.

Wp. pod dn. 6 XI 1551 do akt arcybpa Dzierzgowskiego, zniszczonych $w$ r. 1944 (por. reg.).

Reg. Regesty zapisek, s. 69 .

n transferi kop. $\quad$ miejsce puste $w$ kop. ${ }^{\mathrm{j}}$ possessores kop. $\mathrm{k}$ dodane przez wyd.

7 Akta te nie zachowaty się.

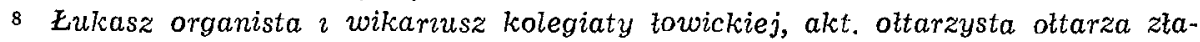
kowskzego.

9 Stefan z Glowna, miasta i par. $w$ dek. strykowskim, misalista kolegiaty tow. $i$ notariusz tejże sprawy.

10 Wawrzyniec Stroniewrcz (a moze ze wsi Stroniewice na ter. par. Domaniewice $w$ dek. Zowıckım Sw. Ducha), misalista i notariusz jak w przyp. 9.

11 Michat notarusz Konsystorza $w$ Eowiczu, autor nın. dok.

25. 1 Mikolaj Dzierzgowski - zob. nr 24, przyp. 4.

2 Sw. Jakub Starszy apostol i męczennik - zob. nr 8, przyp. 10.

3 Sw. Bernard opat Cystersów z Clarvaux we Francji, 1090-1153; kanonizowany w 1174, drem Kościola w 1830 (Radoński: Śwręci, s. 59-60).

4 Bernard Pontificius czyli Biskupski (z Biskupic Olobocznych pod Kaliszem) h. Sreniawa, kanonik lowickı od r. 1544, zm. przyp. $w 1551$ (Wieteska: Katalog, s. 40).

5 Jakub Pontificius albo Biskupski, brat poprzedniego, dr medycyny $i$ ob. prawa, kanonik plocki ok. 1538, sandomierski 1539, towicki 1543 - później tamt. archidiakon, krakowski przed 1545, warszawski; ceniony przez królów i biskupów, zm. $w 1553$ (Niesiecki: Herbarz, t. II, s. 161.- Eętowski: Katalog, t. II, s. 35-37-Wiśniewski: Katalog, s. 23, 85.-Wieteska: Katalog, s. 39-40). 
Regesty dokumentów $\mathrm{zw}$ i ą $\mathrm{z}$ a n y ch z erekcyjnym:

1. Zygmunt August król Polski, wielki ksiqżę Litwy itd.6 zezwala (Kraków, $14 X 1550$ ) Bernardowi Pontificiusowi kanonikowi tow. na ulokowanie na dobrach szlacheckich zamierzonego kapitału, z którego roczny czynsz wynoszqcy ok. 10 grzywien zapewnilby utrzymanie kapelanowi oltarza, jaki pragnie ufundować we wspom. kolegiacie.

Or. ozn. nrem 21 (22) znajdowat się $w$ AAW przed r. 1939 (nota ks. Kwıatkowskiego na s. 288 kopiariusza Sladeckiego).

Kop. AKE: Kopiariusz Sladeckiego sprzed r. 1810, s. 288-289. Tytul: 1550

Consensus Sigısmundi regis super locandis summis et vindicandis in foro spirituali.

Reg. Librowski: Sumariusz, nr 54.

2. Michal notariusz publ. $i$ Konsystorza Lowickiego ${ }^{7}$ oświadcza (Eowicz, 18 III 1552), że Jakub Pontificius dr medycyny $i$ ob. prawa, archidiakon lowicki, kanonitc krakowski, plocki $i$ warszawski, pragnąc powiększyć uposażenie kapelana oltarza - jak wyżej, ufundowanego przez swego brata - jw., darował mu ogród $w$ Lowiczu.

Wp. pod dn. 23 III $1552 w$ akta oficjala lowickiego, spalone $w$ r. 1944 (Regesty zapisek, s. 25).

Kop. AKE: Kopiariusz Sladeckiego sprzed r. 1810, s. 292-293. Tytul: 1552: Donatio horti pro altarista Ssmae Trinitatis per dnum Jacobum Pontificium.

Reg. Librowski: Sumariusz, nr 56

\section{6}

Lowicz, 4 lutego 1552

Hieronim Gawroński kanonik $i$ oficjal lowicki, upoważniony do poniższej dzialalności przez arcybpa M. Dzierzgowskiego, na prośbę Ambrożego. Rudzkiego z Bolimowa dra sztuk wyzw. i medycyny, kanonika tow. - dokonawszy uprzednio odpowiedniego obwieszczenia na temat planów wspom. Ambrożego oraz zapoznawszy się dokladnie z dostarczanymi przez niego dokumentami, tudziė̇ siusznościa jego petycji; kiedy nadto uplyną wyznaczony czas i nie zgloszono $w$ tej materii sprzeciwów - eryguje, przy zgodzie kapituly low., ufundowany przez Rudzkiego w tamt. kolegiacie, za zakrystia $i$ dedykowany już, oltarz ku czci Boga Wszechmogqcego i Najśw. Maryi Panny a pt. św. Piotra i Pawla ap., św. Marcina bpa, św. Anny oraz

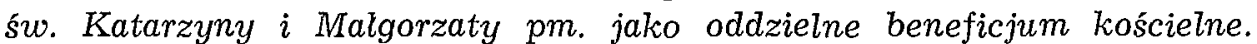
Pierwszym kapelanem oltarza mianowal oficjal, na przedstawienie fundatora, ks. Wincentego Suskiego z Bolimowa. Po śmierci Rudzkiego patronat nad oltaria przejdzie $w$ ręce kapituly. Oprócz domku przy szpitalu na Kierchowie, otrzymywanego od fundatora, oltarzysta ten będzie również posiadal $w$ Lowiczu rolę $z$ ogrodem oraz czynsze płynace z zapisu pieniężnego kanonika Rudzkiego na dobrach szlacheckich. Suski ma odprawiać przy

- Zygmunt August król polski, w. ksiqżę litewski itd. 1548-1572, koronowany za życia ojca wr. 1530 .

7 Michal notariusz - zob. nr 24, przyp. 11, lecz przede wszystkim nr 26, przyp. 29. 
tym oltarzu tygodniowo 3 msze św. $w$ przepisanych intencjach $i$ uczestniczyć $w$ określonych nabożeństwach $w$ kolegiacie.-Dokument spisal $w$ formie instrumentu notarialnego Michat s. Wojciecha $z$ Dmosina Lubozowski not. publ.

or. nie znany.

Wp. 1 pod dn. $3 I I$ (s) 1552 w akta oficjala tow. Gawrońskiego, spalone $w$ $r 1944$ (Regesty zapisek, s. 25).

2 pod dn. $29 \mathrm{~V} 1623$ do akt arcybpa Gembickiego, zniszczonych $w$ r. 1944 (Regesty zapisek, s. 129.-Kopiarnusz Śladeckiego, s. 403, 421).

Kop. AKE: Koprariusz Śladeckiego sprzed r. 1810, s. 403-417 (403-405, 414417) z odpisu wierz. sporz. $z$ wp. 2 w l. 1666-1673, poświadczonego w 1739 (tamże, .s. 421). Tytul niewlaściwy - jak $w$ nrze 27.

Reg. Librowski: Sumariusz, nr 79, 1a-d.

In nomine Domini amen. Ad perpetuam rei memoriam. Immensa Dei ibenignitas Conditoris homini ${ }^{a}$, quem ad suam formavit similitudinem, primi lapsu parentis suorumque labe criminum deformato innumera praestat beneficia et adminicula multa parat, quibus [s. 404] expiare commissa suorumque ${ }^{b}$ disrumpere vincula delictorum, promereri veniam [et reconcilia$\mathrm{ri}^{\mathrm{c}}$ ] suo valeat Creatori; utriusque hospitalitatis opera tanto praestantiora et utiliora ad promerendam ${ }^{\text {d }}$ salutem et gratiam stabilivit, quanto per ipsam maiora et acceptiora obsequia Patri luminum in divini cultus augmento et Dei ministrorum multiplicatione impenduntur ${ }^{1}$. Proinde nos Hieronymus Gawroński canonicus et officialis Ecclesiae Collegiatae Loviciensis ${ }^{2}$, commissarius ad infrascripta et per reverendissimum in Christo patrem et dominum, dominum Nicolaum Dzierzgowski Dei gratia archiepiscopum Gnesnensem, primatem Regni Poloniae et lagatum natum ${ }^{3}$ datus specialiter et deputatus ${ }^{4}$, significamus tenore praesentium, quibus expedit universis et singulis, praesentibus et futuris harum notitiam habituris; quomodo in nostra praesentia constitutus venerabilis ac egregius dominus Ambrosius Rudzki ${ }^{\text {e }}$ de Bolimow artium et medicinae doctor, canonicus Collegiatae Sanctae Mariae Loviciensis ${ }^{5}$ Dioecesis Gnesnensis, zelo devotionis ductus, cupiens pro rebus transitoriis et caducis Christi gratiam et perennis coronae gloriam promereri indeficientesque divitias adipisei ${ }^{6}$, nobis supplicavit, quatenus in dicta ecclesia collegiata altare post sacristiam con-

26. a humani kop. b suorum kop. c opuszczone $w$ kop. d promo-

26. 1 Arenga dokumentu wzięta $z$ nru 7 i częściowo 8.

2 Hieronim Gawroński - zob. nr 24, przyp. 5.

3 Mikoiaj Dzierzgowski - zob. nr 24, przyp. 4.

4 Upowazniene to jest zawarte $w 2$ insercie nin. dokumentu.

5 Ambrozy Rudzki z Bolimowa, miejscowośc kościelnej $w$ dek. lowickım kolegiaty, dr sztuk wyzw. i medycyny, kanonik towıcki 1551-1559. Już $w$ r. 1541 ufundowal $w$ rodzınnym mieście prepozyturę szpit. $z$ kościolem pw. Ducha Sw. (Wieteska: Katalog, s. 40-41).

- Narracja dokumentu podobna jak $w$ nrze 7. 
structum et dedicatum ${ }^{7}$ ad honorem Dei Omnipotentis et Sanctissimae Virginis Mariae, beatorumque eius Petri ${ }^{8}$ et Pauli ${ }^{9}$ apostolorum, Martini ${ }^{10}$, Annae ${ }^{11}$, Catharinae ${ }^{12}$ et Margarethae ${ }^{13}$ pro altarista sive ministro per eum fixo ${ }^{f}$, certis fundo, censibus et reditibus annuis comparato, videlicet agro, censu in vim reemptionis empto per ipsum [s. 405] de bonis et facultatibus suis iuste acquisitis, sufficienter dotato, erigere et fundare, ratificare et approbare, additis ${ }^{\mathrm{g}}$ nonnullis oneribus per altaristam pro tempore existentem ferendis, dignaremur. Nos itaque ipsius optimum desiderium commendantes, nostras ante omnia citationis in vim cridae contra sua interesse communiter vel divisim putantes, in forma solita et consueta, ne per ${ }^{\mathrm{h}}$ celere nostrum decretum alicui in suo iure praeiudicium inferre videremur, duximus praemittendas, et in Dei nomine praemittimus.

Regesty inserow any ch dokumentów.

1. Hieronim Gawroński - jak wyżej, powołując się na upoważnienie otrzymane od arcybpa Dzierzgowskiego, które powtarza, poleca (Lowicz, 23 I 1552) wikariuszom kolegiaty lowickiej, ażeby powiadomili duchowienstwo i wiernych o zamierzonej erekcji ufundowanego przez kanonika Rudzkiego oltarza $i$ donieśli mu o ewent. sprzeciwie, s. 405-408.

2. Mikołaj Dzierzgowski arcybiskup metropolita gnieźnieński - jw., zajęty waznymi sprawami państwowymi, deleguje (Lowicz, 17 XII 1551) oficjala Gawrońskiego do erygowania $w$ osobne beneficjum kościelne ufundowanego $w$ kolegiacie lowickiej przez doktora Rudzkiego oltarza, s. 405-407.

3. Maciej wikariusz wiecz. kolegiaty towickiej 14 powiadamia oficjala Gawrońskiego, $i \dot{z} w$ niedziele 24 stycznia $1552 r$. przeczytał ludowi zgromadzonemu na nabożeństwach wiad. obwieszczenie, s. 408-409.

4. Anna Boniecka ${ }^{15} z$ Lowicza, stanqwszy w towarzystwie męża Franciszka ${ }^{16}$ $w$ miejsc. sqdzie gajowym, zeznala (Lowicz, 23 X 1551) we wlasnym i matki Mal-

vendam kop. e Rucki kop. f fixı kop. g adductis kop. h pro kop.

7 Oltarz zbudowany nakladem Rudzkiego $w$ kolegiacre za zakrystia $w$ dniu wystawıenia dok. erekcyjnego byl już dedykowany, a wręc przynajmnieg poświęcony.

8 Sw. Piotr apostol, pierw. imię Szymon, pierwszy papıez, zm. śmiercia męczeńska $w$ Rzymie $w$ r. 67 . Swieto 29 czerwca (Radoński: Swięci, s. 377-379).

${ }_{9} \quad S w$. Pawet, przedtem Szawet, przybrany przez zmartwychwstalego Chrystusa apostok, ,nauczyciel pogan", ścięty za wiarę $w$ Rzymıe $w$ r. 67. Swięto 29 czerwca (Radoński: Swięci, s. 369-370).

10 Sw. Marcin biskup - zob. nr 7, przyp. 5.

11 Sw. Anna żona św. Joachima, matka Najśw. Maryn Panny. Swięto 26 lipca (Radoński: Swięcr, s. 28-29).

12 Św. Katarzyna panna i męczennica - zob. nr 2, przyp. 4.

13 Ś $w$. Malgorzata panna i męczennica, zw. na Wschodzie Maryna, scięta za wiare $w$ Antiochii $w$ Pizydii ok. r. 307. Swręto 13 (20) lipca (Radońskı: Swięci, s. 308-309).

14 Maciej wikarıusz wiecz. kolegraty lowickiej, blizej nıe znany.

15 Anna z domu Szczepankowa Boniecka, mieszczanka $z$ Lowicza. Swoim darem spowodowała umieszczenıe św. Anny wśród patronów tego oltarza.

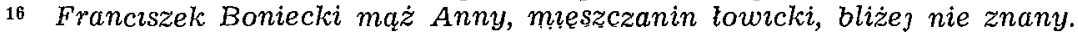


gorzaty Szczepankowej 17 imieniu, że oddala określonq rolę $w$ tym mieście wspom. A. Rudzkiemu na zalożenie ogrodu, s. 409.

5. Hieronim z Trzcianny dziedz. $w$ Woli Pękoszewskiej, lowczy ziemi sochaczewskiej i starosta surogat rawski 18 zaświadcza (Rawa, 11 II 1552), że Dziersiaw Kurzecki dziedz. wsi Rakaciec ${ }^{19}$ zeznat przed jego aktami, jako przyjak od kanonika Rudzkiego zapis 100 kóp gr pol., przynoszqcy rocznie czynszu 6 grzyw. pol., przeznaczonego dla kapelana fundowanego przez tegoż $w$ kolegiacie lowickiej oltarza, s. 410-414.

[s. 414] Die vero dati praesentium comparavit coram nobis praefatus venerabilis Ambrosius, et reproducta altera citationis nostrae crida legitime executa, citantes non comparentes ${ }^{i}$ neque contra praemissa aliquid dicentes $^{j}$ accusavit, ipsosque contumaces pronuntiandos petiit et in eorum contumaciam altare praedictum erigi, agrum censumque emptum ecclesiasticae libertati adscribi et eis auctoritatem ordinariam adici, praesentatum investiri ac ius patronatus adscribi, necnon onera altaristae imponi debita cum instantia supplicavit. Nos itaque petitionem eiusdem attendentes foro ${ }^{\mathrm{k}}$, iuri consonam, bona huiusmodi ecclesiasticae libertati adscribenda et auctoritatem ordinariam adiciendam, altare erigendum, onera imponenda, ius patronatus reservandum, praesentatum ad illud altare investiendum et instituendum duximus, prout auctoritate in hac parte nobis concessa, praedictum altare ad laudem Omnipotentis Dei et Beatissimae Mariae Virginis, beatorumque apostolorum Petri et Pauli, Martini, Annae, Catharinae, Margarethae sanctarum, in angulo postici sacristiae situatum, de consensu venerabilium praelatorum et canonicorum Ecclesiae praedictae Loviciensis ${ }^{20}$, sicut praemissum est, auctoritate ordinaria nobis in hac parte concessa in nomine ${ }^{1}$ [Domini ${ }^{1}$ ] erigimus, creamus et fundamus per altaristam pro tempore existentem regendum et gubernandum, agrumque praedictum una cum censu empto percipiendi et levandi, et in usus beneplacitos convertendi; agrumque et censum praedictum areamque recipimus et admittimus, ratificamus, approbamus et in robur perpetuae firmitatis confirmamus. Et quia altare huiusmodi principali intentione pro laude Summi Dei eiusque Genitricis Mariae saluteque animarum dotatum et institutum est, unde volumus et ordinamus [s. 415], sicque omnibus altaristis pro tempore existentibus sub excommunicationis poena praecipientes et mandantes, qua-

i comparentium kop. 3 dicentium kop. $\mathrm{k}$ fori kop. $\mathrm{l}$ nomini kop.

17 Malgorzata Szczepankowa mieszczanka z Lowicza. Jes imie sluzy do genezy wyjaśnienıa tytulatury nin. oltarza.

18 Hieronim z Trzcianny, wsi na ter. par. St. Rawa w dek. skierniewickim (Trzciński) h. Rawıcz. Wieś Wola Pękoszewska znajauje się w par. Jeruzal Skierniewickı (Niesiecki: Herbarz, t. IX, s. 131.-Rocznik 1958, s. 334, 429).

19 Dziersiaw Kurzecki, moze ze wsi kościelnej Kurzeszyn $w$ dek. rawslım. Wieś Rakaciec albo obec. zaginiona, albo to dzis. Rękawiec na ter. par. Budziszewice dek. raws'sego (Rocznik 1958, s. 390, 395).

20 Por. $n r$ 7, przyp. 10. 
tenus anno quolibet et singulis septimanis tres missas, videlicet die dominico omni de Sanctissima Trinitate cantabit cum duobus adolescentibus de schola, pro qua unam marcam habebunt, iuxta obloquentiam et obligationem in actis officialis Loviciensis habitam et in actis Reverendissimi ${ }^{21}$ fratrum Sal in Kupus ${ }^{22}$, cum collecta pro benefactoribus; feria tertia de Apostolis cum collecta pro fundatore et parentibus eius; feria sexta Requiem pro fidelibus defunctis cum collecta de peccatis, per se aut per alium, legitimo impedimento existente, legat et peragat sine intermissione. Habebitque domunculam circa hospitale in Kierchow ${ }^{23}$, aedificatam sumptibus propriis fundatoris de consensu donationeque venerabilium fratrum Ecclesiae Collegiatae Loviciensis ${ }^{20}$, ad habitandum perpetuo et in aevum tenendum et possidendum. Cuius donationis tenor est descriptus in actis officialis Loviciensis et capituli ${ }^{24}$. Qui quidem altarista in ipsa Ecclesia Loviciensi superpelliceatus infra divina et cantus horarum canonicarum incedere et processionibus, legitimo impedimento non existente, interesse. Ac huiusmodi censum praedictum, si aliquando reemptus fuerit, pro pecuniis capitalibus canalem vel similem reemere et comparare, cum voluntate et consensu scientiaque Capituli Loviciensis praedicti ${ }^{20}$, facultatem habebit, in quo eorum conscientiam oneramus. Quem censum sic emptum, videlicet sex marcarum pro centum sexagenis, et esse dotem altari et altaristae per nos incorporatam, ac agrum et domunculam praedictam cum horto ibidem circa domunculam deinceps ecclesiasticae subicimus libertati. Cuius quidem altaris ius patronatus $[s .416]$ et praesentandi ipse dominus Ambrosius praedictus vita sibi comite habebit et possidebit personasque idoneas, quas voluerit, tempore vacationis reverendissimo domino Ordinario aut successoribus eius archiepiscopis pro

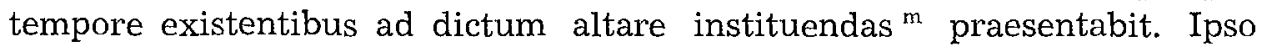
vero Ambrosio vita functo venerabiles praelatos et canonicos totumque capitulum pro tempore existens aut existentes Ecclesiae Sanctae Mariae Loviciensis decernimus dicti altaris esse unicos patronos et collatores, qui tempore vacationis nonnisi idoneam personam actu presbyterum, qui continuo resideat sub privationis poena ad dictum altare domino loci Ordinario praesentabunt instituendum temporibus perpetuo duraturis. Ad quod quidem altare tituli Omnipotentis Dei, Beatissimae Virginis Mariae et beatorum Petri et Pauli apostolorum, Martini, Annae, Catharinae, Margarethae

\footnotetext{
飞 brak $w$ kop. $\quad \mathrm{m}$ instituendos kop. $\mathrm{n}$ assignent kop. o solite kop.

21 Reverendissimus $w$ tym wypadku arcybp Dzierzgowski. Przekaz nie znany, albowıem zarówno akta oficjalskie lowickıe, jak tez arcybiskupie ulegty zagladzie $w$ r. 1944 (Regesty zapısek, s. 3).

22 Osoby $~$ miejscowość nie zidentyfikowane.

23 Przy kościolku pt. św. Leonarda, szpitalnym par. kolegiackiej.- Por. nr 16, przyp. 4.

21 Dokument nie znany, gdyż akta kapituly low. przechowuja sie dopiero od r. 1612 (Wieteska: Katalog, s. 4).
} 
sanctarum habilem virum Vincentium Suski de Bolemow, actu presbyterum Dioecesis Gnesnensis ${ }^{25}$, nobis per venerabilem dominum Ambrosium

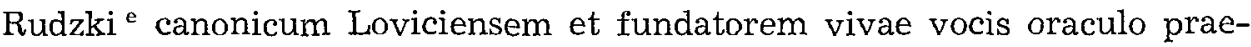
sentatum, per manus nostrae capiti suo impositionem instituimus ac investimus in Dei nomine, administrationem spiritualium et temporalium eiusdem altaris sibi committendo per praesentes. Mandamusque vobis vicariis Ecclesiae Loviciensis Collegiatae praedictae, quatenus praedicto Vincentio altaristae praefati altaris possessionem realem et actualem, omnium iurium, redituum et pertinentium, agri, domus et census reemptionis assignetis ${ }^{\mathbf{n}}$ sub excommunicationis poena. In cuius rei testimonium nostrum sigillum praesentibus est appensum. Actum et datum in Łowicz, in domo nostrae solitae residentiae, quarta mensis Februarii, praesentibus venerabilibus et honorabilibus providisque dominis: Nicolao [s. 417] Krasiński exactore Loviciensi ${ }^{26}$, Matthia Kossic vicario perpetuo ${ }^{27}$, Luca Organista altarista Loviciensi ${ }^{28}$, Francisco Boniecki ${ }^{\mathbf{1 6}}$, ac aliis specialiter ad praedicta rogatis et vocatis. Anno Domini millesimo quingentesimo quinquagesimo secundo.

Et quia ego Michael Alberti Dmosinensis Lubozowski clericus Dioecesis Gnesnensis, sacra auctoritate publicus et saepenominati domini reverendi Commissarii notarius ${ }^{29}$, qui praedictis omnibus et singulis, vestraeque commissionis cum ea, qua decet, receptioni, cridae praemissioni, census annui emptioni, altaris erectioni, institutioni et aliis omnibus et singulis, dum, sicut praemissum est, agerentur et fierent, una cum praenominatis testibus praesens interfui, eaque omnia praemissa vidi et audivi; ideo hoc praesens privilegium seu publicum instrumentum, manu alterius fideliter scriptum, exinde confeci, signoque et nomine meis confectum solitis ${ }^{\circ}$ consignavi et in hanc formam redegi publicam, in fidem praemissorum rogatus et requisitus.

Łowicz, 12 maja 1557

Mikolaj z Dzierzgowa arcybiskup metropolita gnieźnieński, legat urodzony i prymas, na prośbę Ambrożego Rudzkiego kanonika lowickiego,

25 Wincenty Suski kaplan rodem $z$ m. Bolimowa, przyp. krewny fundatora oltarza.

28 Mikolaj ( $z$ Krasnego, wsi kościelnej $w$ dek. Maków Maz.) Krasiński $h$. Slepowron, studiowal $w$ kraju i za granıca, dr teologii; pleban rodzinnej par. Krasne i Zielona $w$ dek. zuromińskim, administrator dóbr arcybiskupich za prym. Dzierzgowskiego $\imath$ Uchańskego; kanonik lowicki $w$ r. 1554, gnieźnieński 1557, krakowski 1572, kustosz kruszwrcki w 1562; zm. w 1575 (Lętowski: Katalog, t. III, s. 173.- Korytkowski: Prataci, t. II, s. 340-341.-Fiutak: Prataci, k. 51.-Wieteska: Katalog, s. 43-44).

${ }_{27}$ Macie Koszyc wikarıusz wiecz. kolegiaty low., bliżej nie znany.

28 Lukasz Organista oltarzysta kolegracki w Lowiczu, bliżej nie znany.

20 Michal s. Wojciecha z Dmosina, wsi kościelnej w dek. strykowskim, Lubozowskz, notariusz publ. z ust. pap. i ofiçala Gawrońskiego. 
wciela ufundowany przez niego w kolegiacie low. $i$ erygowany ( $w$ r. 1552) oltarz ku czci Boga Wszechmogacego i Najśw. Maryi Panny a pt. św. Piotra $i$ Pawła ap., sw. Marcina bpa, św. Anny oraz św. Katarzyny i Małgorzaty pm. do uposażenia kaplicy pw. św. Leonarda op., znajdujacej sie pod patronatem kapituły na przedmieściu Łowicza zw. Kierchow. Jedn. awansuje wspom. kalipce na prepozyture szpitalna (par. kolegiackiej), prepozytem jej naznacza Wincentego Suskiego kapelana wym. oltarza, którego te $\dot{z}-$ na podobieństwo prepozyta szpit. św. Jana Chrzciciela w Łowiczu (miejskiego) - mianuje kanonikiem urodzonym tamt. kolegiaty. Po śmierci doktora Rudzkiego patronat nad nowymi prepozytura i kanonia hon. przejdzie na kapitule low.

Or. nie znany.

Wp. pod dn. $29 \mathrm{~V} 1623$ w akta arcybpa Gembickiego, spalone w 1944 (Regesty zapisek, s. 129.- Kopiariusz Sladeckiego, s. 403, 421).

Kop. AKL: Kopiariusz Sladeckiego sprzed $r$. 1810, s. 417-421 z odpisu wym. $w$ nrze 26. Tytul: Incorporatio altaris pro praepositura in Kierchow et privilegium canonici nati. 1557 ( $s$. 403) oraz Incorporatio eiusdem altaris pro praepositura in Kierchow ad acticandum per eundem Borek ${ }^{1}$ oblata (s. 417).

Reg. Librowski: Sumariusz, nr 79, 2.

Uw. Prawdop. od tego olta`za kościól św. Leonarda nosil potem drugi tytut św. Malgorzaty (Oczykowski: Przechadzka, s. 161-162).

In nomine Domini amen. Ad rei memoriam sempiternam. Quoniam plerumque illa etiam, quae semel ordinata sunt et instituta, ii qui iurisdictioni praesunt piis fidelium affectibus annuentes pro temporum et locorum necessitate aut utilitate personarumque commoditate (prout ratio postulat) divino simul et humano iure permittente in melius et honestius aut utilius commutare consueverunt; maxime autem ea, quae ad maiorem cultum divinum honoremque ecclesiarum cedere dignoscuntur. Proinde nos Nicolaus a Dzierzgow Dei gratia Sanctae Ecclesiae Metropolitanae Gnesnensis archiepiscopus, legatus natus [s. 418], primas ${ }^{1 \mathrm{a}}$ universis et singulis, quibus expedit, tenore praesentium significamus. Quomodo ad nostri veniens praesentiam venerabilis et egregius dominus Ambrosius Rudzki a artium et medicinae doctor, canonicus Loviciensis ${ }^{2}$ humiliter nobis supplicavit, quatenus extructo titulo altaris tituli et invocationis Beatissimae Mariae Virginis et sanctorum Petri ${ }^{3}$ et Pauli ${ }^{4}$ apostolorum ac Martini confessoris pontificis ${ }^{5}$,

\footnotetext{
2\%. a Rucki kop. b adscriptus kop. c Mal kop. ¿ w kop. nastepuje przekreślone octavo

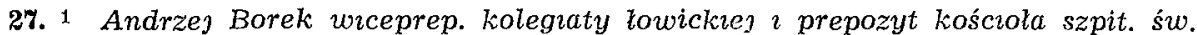
Leonarda ok. 1623 (Kopiariusz Sladeckiego, s. 403, 417).

1a Mikołaj Dzierzgowski - zob. nr 24 przyp. 4.

Ambroży Rudzki - zob. nr 26, przyp. 5 .

Sw. Piotr apostol - zob. nr 26, przyp. 8

Sw. Pawel apostol - zob. nr 26, przyp. 9

Sw. Marcin biskup - zob. nr 7, przyp. 5 .
} 
necnon Annae ${ }^{6}$, Catharinae ${ }^{7}$, Margarethae ${ }^{8}$ in Ecclesia Collegiata Loviciensi sito, non ita pridem sumptu et impensa eiusdem domini doctoris dotato et auctoritate nostra ordinaria erecto et fundato ${ }^{9}$, illud pro praepositura sacelli, quod dicatum est ad laudem et honorem Omnipotentis Dei et in memoriam divi Leonardi in Kierchow alias in suburbio Loviciensi 10 situm, cum omnibus eius altaris proventibus et obventionibus universis incorporare, unire et annectere, in eoque et aliis proventibus ac obventionibus eiusdem sacelli sancti Leonardi per eum ad praesens et in futurum eidem sacello adscriptis ', Praeposituram Pauperum circa hoc idem sacellum degentium, salvis oneribus et officiis divinis dicti altaris per praepositum pro tempore existentem iuxta primam illius ordinationem et erectionem ${ }^{9}$ explendi, denuo erigere et fundare ac litteras nostrae erectionis ipsius praepositurae sibi desuper dare et concedere dignaremur. Nos vero attendentes petitionem dicti domini Ambrosii doctoris fore iustam et rationi consonam, eoque diligenter expenso et intra nosmetipsos cum maturitate ponderató, quod incorporatio huiusmodi et unio cedit in decorem Ecclesiae Collegiatae praedictae Loviciensis, in illaque per hoc crescet pro cultu divino numerus personarum Domino Deo inservientium, praedictum altare modo praedicto una cum universis eius proventibus et obventionibus memoratae praepositurae perpetuo uniendum et incorporandum ac inviscerandum [s. 419] duximus. Prout salvis oneribus et officiis in priore erectione altaris praedicti descriptis ${ }^{9}$ in Dei nomine unimus, incorporamus, invisceramus. Ita videlicet, quod memoratus praepositus sancti Leonardi in Ecclesia Collegiata praedicta Sanctae Mariae Lovicii habeat stallum in choro, in sinistra parte e regione praepositi ecclesiae sancti Ioannis in $\mathrm{LO}^{-}$ wicz ${ }^{11}$, cum superpellicio et almutio canonicali cum dominis canonicis, ac locum in processione immediate ante canonicos cum eodem praeposito ecclesiae sancti Ioannis aut canonicis creatis ${ }^{12}$; ipseque praepositus sancti Leonardi pro tempore existens semper pro canonico nato Loviciensi reputetur et habeatur perpetuo et in aevum. Ius autem patronatus et praesentandi eiusdem praepositurae sancti Leonardi tempore illius vacationis occurrente, iuxta prioris erectionis dicti altaris tenorem ${ }^{9}$, ipsi domino doctori Ambrosio quoad vivet, post mortem autem illius venerabilibus dominis praelatis et canonicis totique Capitulo praedictae Collegiatae Loviciensis perpetuo ascribimus et incorporamus; prout ibidem ad praesens memora-

\footnotetext{
- Siw. Anna matka Najśw. Maryi P. - zob. nr 26, przyp. 11.

Sw. Katarzyna pm. - zob. nr 2, przyp. 4.

Sw. Malgorzata pm. -- zob. nr 26, przyp. 13.

Por. $n r 26$.

10 Por. $n r$ 16, przyp. 4, $n r 17$.
}

11 O prepozyturze św. Jana por. nr 2, przyp. 20, nr 5, przyp. 74, nr 17. W r. 1433 (nr 5) prepozyt św. Jana nie byl jeszcze canonicus natus kolegiaty, ale został nim $w$ ciagu XV stul.

${ }_{12}$ Mowa o innych kanonikach nadliczbowych kolegiaty w Lowiczu. 
tus dominus doctor Ambrosius facto nobis venerabilem dominum Vincentium Suski actu presbyterum ${ }^{13}$ ad eandem praeposituram sancti Leonardi instituendum praesentavit. Quem nos statim et in continenti, recepto primitus $a b$ eo solito corporali iuramento circa institutiones cum fidei suae confessione praestari solito, eoque idoneo reperto, per manus nostrae capiti eius impositionem instituimus ac investimus, curam animarum, administrationem spiritualium et regimen temporalium eiusdem praepositurae sibi committendo. Deinceps vero et in perpetuum vacatione quacumque dictae praepositurae, per cessum vel decessum pro tempore existentis praepositi occurrente, ex tunc memoratum Capitulum Ecclesiae Collegiatae Loviciensis, alias patroni dictae praepositurae, praesentabit seu praesentabunt semper unum de gremio dominorum [s. 420] vicariorum eiusdem Collegiatae Ecclesiae Sanctae Mariae seniorem et plus caeteris de Ecclesia meritum, maioribusque circa ipsam ecclesiam laboribus confectum, per cessum in vicariatus sui, alias sequens accipiat, idque perpetuis temporibus et in aevum. Quae omnia et singula praemissa necnon praesentes litteras et in eis contenta vobis universis, quorum interest aut interesse quomodolibet poterit, in futurum signanter vero dominis praelatis et canonicis totique Capitulo Loviciensi ac illi et illis, ad quem vel ad quos receptio et installatio canonicorum de iure et consuetudine dictae ecclesiae spectat et pertinet, intimamus, insinuamus ac ad eorum et cuiuslibet illorum notitiam indubitatam deducimus eosque nihilominus et eorum quemlibet in solidum requirimus. Ac vobis in virtute sanctae oboedientiae et sub excommunicationis poena mandamus ${ }^{14}$, quatenus, postquam tenore praesentium fueritis requisiti, seu alter vestrum fuerit requisitus, praefatum venerabilem dominum Vincentium Suski praepositum sancti Leonardi in et ad realem, actualem et corporalem dictae praepositurae possessionem recipiant et admittant, stallumque in choro et locum in processione modo praemisso assignent, ponant et inducant, facientes eidem de omnibus et singulis censibus, fructibus et universis obventionibus per eos, ad quos spectat et pertinet plenarie et integre responderi et vos ipsi, quantum in vobis est, respondeatis. In quorum omnium et singulorum fidem et testimonium praemissorum sigillum nostrum praesentibus est subappensum. Datum in arce nostra Loviciensi duodecima mensis Maii ${ }^{c}$ anno Domini millesimo auingentesimo quinquagesimo ${ }^{\text {a }}$ septimo. Praesentibus reverendis, venerabilibus, generosis, nobilibus et discretis viris: Stanislao Dambrowski curiae nostrae can-

13 Wincenty Suski - zob. nr 26, przyp. 25.

$14 Z$ sankcji tych wynika, że przeforsowanie nowego $i$ słabo uposażonego prepozyta św. Leonarda na kanonika urodzonego kapituly tow., zw. później honorowym, nie było latwe.

${ }_{15}$ Stanisiaw (z Zielonej Dabrowy, wsi kościelnej $w$ dek. gidelskim) Dabrowski h. Poraj, 1501-1575; w r. 1521 bak. Uniw. Krak., potem ar ob. prawa na uczelni zagr. Prepozyt wolborski, kanonik wloclawski 1535, tamt. oficjat gen. 1541, 1545, kanonik 
cellario ${ }^{15}$, Francisco Krasiński iuris utriusque, Gnesnensi, Cracoviensi ${ }^{16}$, Adamo medicinae doctoribus, Crusviciensi ${ }^{17}$ canonicis, Ioanne Nakolski Samotuliensi decano ${ }^{18}$, Thoma Lasocki pincerna Dobrzynensi [s. 421] curiae nostrae mareschalco ${ }^{19}$, Stanislao Baliński Unieioviensi ${ }^{20}$, Stanislao Orlik in Blogie 21, Iacobo Gosczanowski in Opatówek ${ }^{22}$ plebanis.

Mikolaj $z$ Dzierzgowa arcybiskup metropolita gnieźnieński, legat urodzony i prymas Król. Polskiego - odnowiwszy kaplicę zamkowq w Lowiczu, która w r. 1556 dedykowal na chwatę Boża a ku czci św. Mikolaja bpa, św. Anny i św. Barbary pm. Leonard (Stończewski) biskup kamieniecki eryguje przy niej beneficjum prebendarskie. Obdarza przeto prymas, za zgoda kapituly metrop. gnieźnieńskiej, kapelana wspom. kaplicy, za obowiazki mszalne spelniane $w$ niej 4 razy $w$ tygodniu, dziesięcina snopowa $z$ ról chlopskich wsi Redzeń i Swięte, należna dotad do stolu arcybiskupiego, przyznaje mu mieszkanie i utrzymanie $w$ miejsc. pałacu oraz dopuszcza do stroju kanonickiego w kolegiacie lowickiej.

gnieźnieński 1547, krakowski 1554, łowıcki 1559, archıdiakon kurzelowski, kantor gnıeźn. 1556, tamt. archid. 1558, tenze lęczycki 1559. Kanclerz kurii bpa wtoct. J. Karnkowskiego a później arcybpów Dzierzgowskıego, Przerembskiego $i$ Uchańskiego; administrator gen. archidiecezji w 1560, wikariusz kap. 1562; bral udzial w synodach $\imath$ sejmach, ułożyl statuty kolegum wikariuszy w Wolborzu, dopomógł bpowi wloct. S. Karnkowskiemu do opracowania Synodyku gnieźn. (1579). Byl plebanem we wsi rodzinnej, $w$ której ufundował koścı́l (1554), a także w Ostrowitem $i$ Waliszewie (Lętowski: Katalog, t. II, s. 165.- Korytkowski: Prakaci, t. I, s. 194-203.- Chodyńskn: Katalog, s. 133-135.-Wieteska: Katalog, s. 42).

18 Franciszek (z Krasnego, wsi kościelnej $w$ dek. Maków Maz.) Krasiński h. Slepowron, 1525-1577; studiowat $w$ Wittenberdze, Krakowie a Rzymie, skad przywıóz drat ob. prawa (1551). Archıdialcon kaliski, kanonik krakowski 1555, gnieźnıeński 1556, lucki, lowick 1557; prepozyt plocki 1566, archıdiakon warszawski i pralat poznański 1569; biskup krak. 1571. Sekretarz król. 1559, podkanclerzy kor. 1.568; dwukrotnıe poslowal od episkopatu pol. do pap. Pawla IV $(1555,1556)$ i tyleż od Zygmunta Augusta do ces. Maksymiliana II (1566, 1568); $z$ ostatnich poselstw pozostawil diariusz, czynny uczestnik synodów i sejmów, jedyny spośród biskupów podpısat $w$ r. 1573 akt konfederacii warsz.; biskup gorliwy, dobroczyńca, a jednocześnie polityk $i$ patriota (Eętowski: Katalog, t. II, s. 136-139.- Korytkowskı: Prataci, t. II, s. 333-340.- T. Gostyński: Fr. Krasiński, polityk zlotego wielku, Warszawa 1938.- Szostkiewicz: Katalog, s. 103.- PSB (W. Urban) t. XV: 1970, s. 171-173.-Wieteslca: Katalog, s. 43).

17 Adam dr sztuk wyzw. i medycyny, kanonik kruszwicki w l. 1557-1558, może lekarz arcybiskupi (Fiutak: Prataci, k. 1).

18 Jan Nakolski dziekan kolegiaty $w$ Szamotulach.

19 Tomasz Lasock h. Dolęga cześnik dobrzyñski, marszalek dworu prym. Dzierzgouskiego.

20 Stanısław Baliński pleban par. Uniejów, pewnie wikariusz wıecz. tamt. kolegraty.

21 Stanistaw Orlik pleban par. Blogie w dek. żarnowskim.

22 Jakub Goszczanowski (może z Goszczanowa) pleban par Opatówek w dek. kaliskim II. 
Or. nie znany.

Kop. $A A G, B 5$ : Kopiariusz z lat 1459-1585, k. 401v-402v. Tytut: Erectio sacelli Castrı Louiczensis.

Wzm. 1. Korytkowski: Arcybiskupi, t. III, s. 216.

2. Oczykowski: Przechadzka, s. 108.

Uw. 1. Pismo dokumentu malo czytelne, jego treść częśc. zneksztalcona.

2. Por. $n$ r 3 .

In nomine Domini amen. Ad perpetuam rei memoriam. Pendens humani generis industria litterarum genus ${ }^{a-}$ adunire scribae ${ }^{-a}$, ut is res longa memoria dignas conscriberet redderetque perpetras. Proinde nos Nicolaus a Dziergow Dei gratia Sanctae Ecclesiae Metropolitanae Gnesnensis archiepiscopus, legatus natus et Regni Poloniae primas ${ }^{1}$ universis et singulis harum notitiam habituris praesentibus significamus. Quod dum considerassemus in turri [ $k$. 402] castri Loviciensis superioris capellam grandem, ubi laus divina peragi solita est, vetustate et incuria hominum penitus corruisse et in nihilum ferme redactam ${ }^{2}$, prout et alia castri illius aedificia, denuo restaurandam adornandamque, ne scilicet locus ille, ubi aliquando Deo Omnipotenti serviebatur, vacesset dignum esse putavimus. Atque inibi ad laudem Dei Omnipotentis et honorem ${ }^{3}$ sancti Nicolai ${ }^{4}$, sanctae Annae ${ }^{5}$, sanctae Barbarae ${ }^{6}$ titulo eorundem anno Domini 1556 per reverendissimum dominum Leonardum Dei gratia episcopum Camenecensem ${ }^{7}$ consecratam; sacerdotem ecclesiasticum praebendatum fundandum et donandum, prout fundamus, erigimus et dotamus; eidem praebendato sacerdotio [s] decimas manipulares post agros cmenthonales villarum nostrarum Radzydlo ${ }^{8}$ [et ${ }^{b}$ ] Swyaczye ${ }^{9}$, ad mensam nostram archiepiscopalem pertinentium, sub ratihabitione venerabilium fratrum nostrorum praelatorum et canonicorum Venerabilis Capituli Ecclesiae nostrae Gnesnensis ${ }^{10}$, dandas, assignandas censuimus. Iusque patronatus et praesentandi eius praebendae capitaneo nostro Loviciensi ${ }^{11}$, nunc et pro tempore ac in futurum existenti, reservamus perpetuo et in aevum tenore praesentium me-

28. a-a lekcja prawdopodobna b dodane przez wydawce c $w$ kop. na-

28. 1 Mikolaj Dzıerzgowski - zob. nr 24, przyp. 4.

2 O tej kaplicy mówo nr 3.

$3 \quad$ Stara kaplica zamkowa nosila tytul św. Marii Magdaleny (por. nr 3).

4 Sw. Mikolaj bp - zob. nr 7, przyp. 4.- Do genezy tytulu kalipcy: Dzierzgowskiemu bylo na ımie Mikolaj.

$5 \quad$ Sw. Anna - zob. nr 26, przyp. 11.

- $S w$. Barbara pm. - zob. nr 6, przyp. 10.

- Leonard Stończewski h. Koścıesza, mgr teologii Unıw. Krak., miechowita, biskup

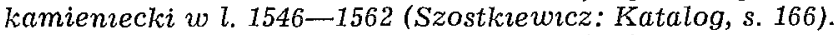

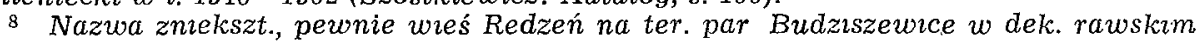
(Rocznik 1958, s. 390).

${ }_{9}$ Swręte, wieś w par. Maków dek. skiernewickıego (Rocznik 1958, s. 425).

10 Por. nr 2, przyp. 8.

11 Starosta czyli kasztelan arcybiskupiego zamku towickıego byt ıuż od r. 1433 patronem prazatur $\imath$ kanonii $w$ tamt. kolegiacie (zob. nr 5), a od $r 1522$ - takze archidiakonii ( $n$ r 18). 
diante. Qui quidem capitaneus ad eandem praebendam toties quoties vacantem nobis nostrisque successoribus personam gratam praesentabit de illa instituendam. Et quia beneficium datur propter officium, ideo statuimus, ordinamus et volumus, ut dictae capellae nostrae Loviciensis praebendarius pro tempore ${ }^{c}$ existens missas infrascriptas in qualibet septimana: unam scilicet de Sancta Trinitate vel alternatim singulis diebus dominicis, alteram de sancta Anna feriis tertiis, tertiam feria sexta de Passione Domini cum oratione pro peccatis, sabbato vero de Beata Maria Virgine in eadem capella coram nobis, successoribus nostris vel castri familia, per se vel per alium, cantans vel legens sit astrictus. Licitum autem erit eidem praebendario in Ecclesia nostra Collegiata Loviciensi uti superpellicio ${ }^{12}$. Qui quidem capellanus seu praebendarius eiusdem castri nostri in eodem castro nostro personaliter residebit sub amissione ipso [k. 402v] facto beneficii. Cameram pro residentia per capitaneum sibi in castro vel ante castrum designatam " expensasque mensae in castro eodem una cum puero, qui in divinis adiuvabit intueri familiam castrensem; locumque ad mensam penes capitaneum est habiturus. Quae omnia praemissa decernimus perpetuo valitura tenore praesentium. In cuius testimonium nostrum et dicti capituli nostri sigilla praesentibus sunt appensa. Datum et actum Lovicii die duodecima Octobris anno Domini 1557. Praesentibus venerabilibus et generosis: Hieronymo Garwaski Ecclesiae Gnesnensis ${ }^{13}$, Stanislao Dąmbrowski iuris utriusque doctore, curiae nostrae cancellariis atque canonicis Gnesnensibus ${ }^{14}$, Francisco Krassynski iuris utriusque doctore, archidiacono Calissiensi, Gnesnensi, Loviciensi ${ }^{15}$, Iacobo Milyewski decano Lenciciensi, Cracoviensi, Loviciensi ${ }^{\mathbf{1 6}}$ canonicis; Thoma Liassoczki tribuno $\mathrm{Nu}-$ rensi ac curiae nostrae marszalco ${ }^{\mathbf{1 7}}$, Ioanne Klinszowski succamerario nostro ${ }^{18}$ et aliis compluribus curiae nostrae praelatis atque aulicis.

stępuje nieudany $i$ przekreślony wyraz existens a designantem kop.

12 Jest to juz trzeci przyklad na uzyskanie przywileju kanonickiego $w$ kolegiacie tow. Pierwszym był prepozyt kościola szpit. sw. Jana (zob. $n r$ 5, przyp. 74 i $n r$ 27, przyp. 11), drugim - prepozyt kościola szpit. św. Leonarda (nr 27). Ci dwaj byli jednaḱ kanonikami urodzonymi wspom. kolegiaty.

${ }_{13}$ Hieronim Garwaski h. Grzymała kanonik gnieźnieński od 1547, krakowski 1551, lowicki przed 1554, plocki 1563, tęczycki, uniejowski. Kanclerz arcybpa Dzierzgowskiego od 1554, sekretarz król. przed 1579, zm. w 1583 (Lętowski: Katalog, t. II, s. 240.Korytkowski: Pralaci, t. II, s. 43.- Wieteska: Katalog, s. 42).

14 Stanistaw Dabrowski - zob. nr 27, przyp. 15.

15 Franciszek Krasiński - zob. nr 27, przyp. 16.

16 Jakub Milewski h. Jastrzębiec podskarbi arcybpa Dzierzgowskiego, kanonik gnieźnieński 1550-1583, krakowski 1564, wlocławski 1559-1583, dziekan lęczycki przed 1559, lowicki 1559-1579, biskup tyt. laodycejski a sufragan krakowski od 1579, zm. 1586. Wspólnie ze S. Dąbrowskim (przyp. 14) postowat $w$ imientu kapitul pol. do papreża $w$ sprawie dyspensy a pluralitate beneficiorum (Eętowski: Katalog, $t$. III, s. 344.- Korytkowski: Prakaci, t. III, s. 4-8.- Chodyński: Katalog, s. 473.- Szostkiewicz: Katalog, s. 128.- Wieteska: Katalog, s. 42.- PSB (H. E. Wyczawski) t. XXI (1976) :s. $210-211$ ).

17 Tomasz Lasocki wojski nurskı - zob. nr 27, przyp. 19.

18 Jan Klinszowski podkomorzy dworu prym. Dzierzgowskiego, bliżej nie znany. 
Mikolaj Dzierzgowski arcybiskup metropolita gnieźnieński, legat urodzony $i$ prymas - wcielajac $w$ czyn konstytucje apostolskie, zwlaszcza pap. Leona $X$, oraz synodów prowincjalnych — za rada $i$ zgoda kapituly metrop. gnieźnieńskiej, rezerwuje w kościolach kolegiackich archidiecezji: lęczyckim, uniejowskim, lowickim, kurzelowskim, kaliskim i wieluńskim po jednej prebendzie kanonickiej dla doktorów teologii i prawa lub przynajmniej dla magistrów filozofii wzgl. sztuk wyzw., którzy by rezydujac przy nich pelnili tam obowiązki kaznodziejskie. I tak $w$ Łęczycy kanonia doktoralna kaznodziejska będzie odtad prebenda zajmowana przez kanonika Feliksa Ciesielskiego, w Uniejowie - przez Piotra Gawareckiego, w Lowiczu przez dra Ambrożego z Bolimowa, w Kurzelowie - przez Wawrzyńca $z$ Plocka, w Kaliszu, gdzie akt. brak kanonii patronatu arcybiskupiego, Dzierzgowski poszuka dla tego celu innej, w Wieluniu będzie na razie kaznodzieja prepozyt, magister sztuk wyzw. Po zatwierdzeniu swego planu obiecuje prymas zwrócić się do Stolicy Ap., a nawet prosić papieża, by na ten cel przeznaczyl również pewne prebendy, których obsadzanie wypada w tzw. miesiacach papieskich.

Uw. Dokument nin. zostanie opublikowany $w$ tomie 2, poświęconym kościelnemu ośrodkowi lęczyckiemu.

'(Lowicz) ok. 28 czerwca 1563

Jakub Uchański arcybiskup metropolita gnieźnieński, legat urodzony i prymas ${ }^{1}$, względnie z jego upoważnienia oficjal lowicki Żabiński ${ }^{2}$, eryguje $w$ kolegiacie lowickiej oltarz (oltarię) pt. Przemienienia Pańskiego, św. Anny, św. Mikolaja bpa i św. Malgorzaty pm.

Or. nie znany.

Wp. 1 pod dn. 28 VI 1563 do akt Konsystorza Łow., spalonych w r. 1944 (Regesty zapisek, s. 30).

2 pod $d n .8 \times 1578$ w akta arcybpa Uchańskiego, zniszczone $w$ r.' 1944 (Regesty zapisek, s. 87).

3 pod dn. 30 XII 1586 do akt arcybpa Karnkowskiego ${ }^{3}$, spalonych $w$ r. 1944 (Regesty zapisek, s. 93).

Uw. 1. Zapisy fundacyjne dla oltarii mialy miejsce jeszcze za rzadów arcybpa

30. 1 Jakub Uchański - zob. nr 31, przyp. 1.

2 Zabıński ofiçal lowıcki w l. $1561-1573$ i prawdop. kanonik tamt. kolegiaty (Regesty zapisek, s. 29-32).

3 Stanislaw Karnkowski - zob. nr 32, przyp. 1. 
Przerębskiego ${ }^{4} w$ dn. $6 \imath 11 \times 1560$ (Regesty zapisek, s. 79), a 18 listopada tr. wspom. prymas czynil przygotowania do jej erekcji (tamze, s. 79).

2. W późnıejszych latach oltarz ten nazywano krótko. św. Anny.

\section{1}

Lowicz, 24 grudnia 1564

Jakub Uchański z Magnuszewa i Stużewa arcybiskup gnieźnieński, legat urodzony i prymas Król. Polskiego, nawiqzzując do rozporzq̨dzenia Soboru Trydenckiego o nauczaniu chrześcijańskim oraz wspominajacc, że to nauczanie niemal od poczq̨tku swego istnienia Kościól związal z niższymi święceniami kaplańskimi, a dzisiaj jest zaniedbane, funduje i eryguje za zgoda kapituly metrop. gnieźnieńskiej - jako oddzielne beneficjum przy obu kaplicach zamku arcybiskupiego w Lowiczu: Trójcy Sw. $i$ św. Barbary staly urzadd lektora czyli anagnosty, który by prowadzit $w$ jęz. polskim dla zatrudnionych $w$ grodzie lekcje katechizmu $i$ wyklad psalterza wedlug wskazanych przez prymasa podręczników. Nowego beneficjata prawodawca uposaża dziesięcina snopowa $z$ majatku arcybiskupiego Nowy Dwór $i$ dziesięcina w ziarnie ze wsi prymasowskiej Dzierzgowice - obydwu polożonych $w$ pobliżu Lowicza, $z$ czego jednak 5 grzywien rocznie będzie on musial przekazywać kapitule lowckiej na 4 aniwersarze nalożone jej przez Uchańskiego. Prawo wyboru bandydatów na katechete przyznaje arcybiskup kapitule low., która ma desygnować ze swego grona 3 elektorów, ażeby upatrzyli spośród miejsc. Dominikanów oraz duchowieństwa archidiecezjalnego miasta, biorac pod uwage tak kaplanów, jak też kleryków i nie wykluczając wykwalifikowanej osoby świeckiej, 3 kandydatów liczacych najmniej po 22 lata, przeegzaminowali ich oraz stawili do kolegiaty na publiczna prelekcje każdego i glosowanie. Prawo glosu przysiuguje wszystkim duchownym Lowicza, urzędnikom tamt. magistratu oraz starszym bractw $i$ cechów. Zwycięzca $w$ wyborach zostanie lektorem $w$ zamku. Będzie on podlegal jurysdykcji kapituly low. Powinien nauczać codziennie rano, przed rozpoczęciem prac $w$ grodzie, jego mieszkańców prawd wiary przynajmniej w ciagu jednego kwadransa. Obecność wymienionych na lekcjach obowiązkowa pod sankcjami pieniężnymi. Nad porządkiem, frekwencja i stosowaniem sankcji obejmie nadzór wicestarosta low.

4 Jan (z Przeręba, wsı kośc. w dek. chelmskim diec. częstochowskiej) Przerębski (Przerembski) h. Nowina, 1519-1562; studiowal w Krakowie z Padwie. Kanonik i pralat kilku kapitul, administrator diec. krakowskıej w r. 1550, sekretarz król., podkanclerzy kor 1551-1558, posel Zygmunta Augusta do ces. Ferdynanda $I$ w 1553 i 1559, buskup chelmski 1557, koadiutor arcybpa gnıeźn. Dzierzgowskiego 1558, tamt. arcybiskup i prymas 1559. Zwolywał synody, reformował szkolnactwo, pierwszy $z$ prymasów pochowany w Lowiczu (Korytkowski: Arcybiskupi, t. III, s. 229-271, t. V, s. 349.-Kwiatkowski: Kapitula, s. 103 oraz il. 20 po s. 80.- Szostkiewicz: Katalog, s. 152-153). 
Or. nie znany.

Kop. 1 - wspólcz. AAG, B5: Kopiariusz z lat 1459-1585, K. 452-454v. Tytul: Privilegium lectoris seu anagnostae Lowicensis.

2. AKE: Kopiarusz Sladeckiego sprzed r. 1810, s. 308-315, z uwrerz. odp. sporz. na pocz. XVIII w. przez J. Romana not. publ. $z$ ust. pap. i kap. gnieźn., który wykonal go na podstawie kop. 1 (tamze, s. 315). Tytut: 1564. Erectio anagnostae seu cathechistae qualificati in Arce Loviciensı. J. Uchańskı.

Reg. Librowski: Sumarrusz, nr 62.

Wzm. 1. Korytkowski: Arcybiskupi, t. III, s. 316-317.

2. Oczykowskn: Przechadzka, s. 108.

In nomine Domini amen. Ad perpetuam rei memoriam. Iacobus Uchański de Magnuszewo et Służewo Dei et Apostolicae Sedis gratia archiepiscopus Gnesnensis, legatus natus et Regni Poloniae primas ${ }^{1}$. Testatum facimus universis, quibus expedit, quod nos piis adhortationibus decretorum reformationis Sacrosanctae Tridentinae Synodi 2 adducti et functionum sanctorum ordinum minorum iam inde a temporibus apostolorum in Ecclesia Dei laudabiliter receptorum, legitimum et verum usum, qui hactenus propemodum non sine gravi Ecclesiae damno intermissus est, per Dei gloriam reducere et restituere volentes, ne amplius dicti sacri ordines ab haereticis tamquam otiosi in grave populi christiani scandalum traducant, aliisque gravibus causis, imprimis cura officii nostri pastoralis hoc exigentibus, provida meditatione et salubri deliberatione divina suadente gratia et consilio nonnullorum venerabilium fratrum nostrorum praelatorum et canonicorum Ecclesiae nostrae Metropolitanae Gnesnensis moti, officium seu beneficium pro lectore sive anagno- [s. $309 w$ kop. 2$]$ sta cathechismi, psalmorum Davidis et precularum in arce nostra Loviciensi, in capella utra= que titulorum Sanctae Trinitatis ${ }^{3}$ et sanctae Barbarae ${ }^{4}$ fundandum et erigendum intendimus ad gloriam Omnipotentis Dei et piam educationem

31. 1 Jakub z Magnuszewa i Sluzewa Uchañskz h. Radwan (1502-1581), pralat $\imath$ kanonik kilku kapitul, sekretarz król. i referendarz kor. 1538-1550, sprzyjal róznowierstwu, $w$ r. 1550 usilowano $w$ Krakowie dokonać zamachu na jego życie. Biskup chelmski 1551-1559 - byly trudnośc z prekonizacja; nie czekając na potwierdzenie papıeskie objal w 1559 diec. wtoclawska; wyklęty za to przez Pawla IV, tym samym odwzajemnil sı̨ papiezowi, bıskup wioclawsk 1561-1562. Jało arcybiskup gnieźnień-

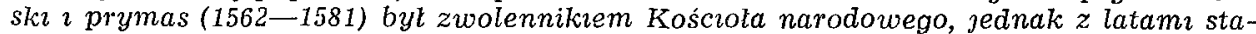
wal się znowu katolickım; zwolujac synody diecezjalne $\imath$ prowinçalne. W $r$. 1576 nie uznawai Batorego za króla; $w$ późnejszych dokumentach przybral do tytulatury element „prerwszy ksiqze”". Drugi spośród prymasów pochowany w Łownczu w ufundowanej przez siebıe ok. r. 1580 kaplicy w tamt. kolegıacıe. Postać kontrowersyjna, pelna zalet 2 wad, godna nowej monografii (Estreicher: Bibliografia, $t . X X X I I, s .6-8 .-$ T Wierzbowskl: Uchansciana, t. 1-5, Warszawa 1884-1895.- Korytkowskl: Arcybiskup , t. III, 272-418, t. V, 367-368.- Kwiatkowskl: Kapttuia, s. 80, 83-84, 103 oraz il. $22=89 .-$ Szostkiewicz: Katalog, s. 186-187). 1563

2 Sobór Trydenck trwal w l. 1545-1563; najbardzıej owocnymi byly l. 1562-

3 Kaplica zamkowa $w$ Lowiczu pt. Trójcy Sw. byla dotad nie znana. Moze to kościól dla tzw. grodzlan czyli podgrodzia, przyp. filialny na ter. par. kolegiackiej.

4 Kaplica zamkowa pw. św. Barbary - por. $n r$ 28. Jej poprzednica nosila tytut św. Marii Magdaleny - zob. nr 3. 
atque institutionem illorum, qui in arce degentes distinctis officiis et muniis ad certas curas, operas et labores ibidem praestandos sunt adstricti. Dictumque beneficium seu officium pro futuri lectoris sive anagnostae sustentatione, cuius officium inferius expressum est, dotare decrevimus, prout vigore praesentium de consensu et ratihabitione venerabilium fratrum nostrorum praelatorum et canonicorum Capituli Ecclesiae nostrae Metropolitanae Gnesnensis ${ }^{\mathbf{5}}$, omni meliore ratione, modo et forma, quibus de iure et consuetudine possumus ac debemus, in dictis capellis perpetuo duraturum fundamus et erigimus. Atque pro futuri lectoris sustentatione lecturae dictae, lectorique eidem praeficiendo et perpetuis temporibus pro tempore existenti, ex certa scientia et ex méra et pura liberalitate atque spontanea,voluntate dotantes damus, assignamus, donamus et tradimus decimas nostras manipulares ex omnibus agris praedii nostri Novi Dwor a6 inter villam nostram Bobrowniki ${ }^{7}$ et civitatem Lovicz ${ }^{b}$, necnon decimas totius villae nostrae Dzirgovicze ${ }^{c 8}$, ad piscinam nostram Novina ${ }^{\mathrm{d}}$ sive Kuf$\mathrm{fel}{ }^{9}$ in Districtu Loviciensi sitarum, omnis generis grani quotannis ex tritico, siligine, avena, hordeo [k. $452 v$ w kop. 1], piso, milio et quolibet genere frumenti sati, ibidem provenientes, traditione, assignatione atque donatione firma et perpetua, quae amplius quacumque de causa numquam revocari possit et valeat, neque etiam per quemquam debeat. Ita quidem, ut dictum beneficium [s. $310 w$ kop. 2] seu officium lecturae, sic a nobis fundatum atque erectum, et futurus lector eidem legitime praefectus, et quicumque pro tempore legitime creatus existens, praedictas decimas manipulares omnis generis grani et seminis ex omnibus agris Novi Dwor et villae nostrae Dzirgovicze provenientes, totumque superius cessum, assignatum, donatum et traditum, ex causis iam dictis et latius experimendis, quotannis libere recipiat. Easque ibidem vendendi vel inde in alia bona nostra vel sua qualiacumque sive aliena transferendi, deque is libere disponendi omnimodam potestatem habeat, eisdemque, prout sibi melius esse et expedire existimaverit, utatur et fruatur, inque suos beneplacitos usus convertat sine nostra et nostrorum successorum vel capitaneorum, vel vicecapitaneorum Loviciensium, aut aliorum servitorum nostrorum vel aliorum quorumcumque hominum contradictione et impedimento. Ad

31. a Nowy Dwor kop. 2 b Lowicz kop. 2 c Dzierzgowicze kop. 2

5 Por. nr 2, przyp. 8.

- Nowy Dwór, majątek polożony między Łowiczem a wsia Bobrowniki, nie występ. $w$ lit. hist.

7 Bobrowniki, weś $w$ par. kolegiackiej $w$ Eowiczu (Rocznik 1958, s, 307.-Warężak: Slownik, cz. II, z. 1, s. 49-52).

8 Dzierzgowıce, potem Dzierzgów, wieś na ter. par. Bełchów w dek. lowickim kolegiaty, założona pewnie przez arcybpa Dzıerzgowskiego + 1559 (Rocznik 1958, $\mathrm{s}$. 301.- Warężak: Slownik, cz. II, z. 1, s. 93-95).

9 Staw rybny Nowina czyli Kufel nie cyt. $w$ lit. hist. 
quam libertatem illi perpetuo servandam omnes successores nostros et officiales et servitores nostros et successorum nostrorum, speciatim vero capitaneum et vicecapitaneum Loviciensem modernos et pro tempore existentes, firmissime obligamus sub poenis a conservatoribus per Sedem Apostolicam quandocumque deputandis huius nostrae fundationis et erectionis contra ipsos extendendis. Illud quoque omnino volumus, ne unquam dictus futurus et pro tempore existens lector capitaneo vel vicecapitaneo Loviciensi, aut aliis familiaribus nostris, seu reverendissimorum dominorum archiepiscoporum Gnesnensium successorum nostrorum, et ab eis subordinatorum ac submissorum personis, vel eidem Venerabili Capitulo, aut ab. eo [s. 311 w kop. 2] subordinatis personis decimas dictas vendat sub excommunicationis poenis in ipsum a dictis conservatoribus fulminandis. Disponimus autem, constituimus et ordinamus, ut ex nunc et deinceps perpetuis temporibus dictae nostrae fundationis et erectionis beneficii praedicti ius electionis ad Venerabile Capitulum praelatorum et canonicorum Ecclesiae Collegiatae Beatae Mariae Virginis Loviciensis pertineat et spectet. Quod quidem capitulum sortione tres electores de numero suo deligat, quibus plenam potestatem et facultatem facimus, ut tres viros clericos regulares Ordinis Praedicatorum ${ }^{10}$ vel saeculares $[k .453 w k o p .1]$, in maioribus vel minoribus ordinibus constitutos, eligant natalibus, aetate, moribus, doctrina et vita inculpatos, viginti duobus annis non minores, et quos secundum veteres et Sanctae Tridentinae Synodi recentes canones, matura deliberatione et iudicio in singulorum doctrinam, vitam et mores inquisitione facta idoneos repererint, eosdem die sollemni ex suggesto, populo frequenti die dominica vel sollemne immediate sequente, ecclesiae sistendos et publicis suffragiis per calculos unum illorum ad officium praedictum eligendum esse denuntiari curabunt. Ubi constituti singuli publice ex suggesto aliquid populo praelegere et omnibus eruditionis suae specimen declarare debent, ibidemque publicis precibus praemissis ad Dominum, ut ostendat, quem. eorum velit abire in locum ministerii huius, suffragisque a praelatis, canonicis, vicariis et totius civitatis clero, necnon advocato, proconsulibus et consulibus, scabinis et senioribus societatum seu fraternitatum per calculos. editis, verus et indubitatus lector haberi et legitime electus censeri debebit. ille, qui ex tribus nominatis [s. 312 w kop. 2 ] multitudine suffragiorum, tacite per calculos factorum, reliquos vicerit. Debent autem eiusmodi tacita suffragia ordine fieri pro conditione suffragatorum initio a clericis. facto. Cui electioni praeerit, ut decenter atque ordine omnia fiant iuxta praescriptum modum praelatus vel canonicus senior protunc praesidens. in ecclesia. Quoniam vero Sancta Synodus Tridentina coniugatos ad mino-

10 Klasztor Dominikanów fundowano $\imath$ erygowano $w$ Łowıczu $w$ l. 1400-1414. Zob. $n r 4$. 
res ordines admittit ${ }^{11}$, itaque nos quoque ab eo munere lecturae coniugatum doctrinae, modestiae, pietatis vitae denique totius honestum testimonium habentem non excludimus, ad praescriptum tamen sacrorum canonum sanctarum synodorum qualificatum. Leget autem praedictus lector singulis diebus per totum anni circulum Cathechesim Cyrilli sancti archiepiscopi Hierosolymitani ${ }^{12}$, dum Cathechismus ex ordinatione Sanctae Tridentinae Synodi praescribendus edatur 13. Quo edito alternis vicibus dictae cathecheticae institutiones per ipsum lingua vernacula et nulla alia legentur, ita tamen ne alternis lectionibus cathecheses dictas confundat, sed alterius, quam praelegendam susceperit, serie ad finem perducta, tum demum - alteram inchoet, singulis diebus ad minus ad horae quadrantem per se, et non per aliquem substitutum, sub privationis poena lectione continuata. Diebus vero dominicis et festis Psalmos a beato Theodoreto Cyrensi e episcopo ${ }^{14}$ explicatos. Cum eiusdem [k. 453v w kop. 1] explicatione eadem lingua vulgari vernacula saepedictus lector praeleget additis post lectionem tam cathechismi, quam psalmorum quotidie tribus vel quattuor precatiunculis, vulgari lingua per nos expositis ${ }^{15}$, quae etiamnum in Ecclesia Collegiata Sanctissimae Virginis Mariae Lovicii usurpantur. Hieme quidem et sub finem autumni unicuiusque veris ante lucem [s. $313 w$ kop. 2] aestatis vero tempore ad primam lucem, priusquam operis quicquam facient in arce nostra, ut supra dictum est, degentes. Dicti autem lectoris lectioni singulis diebus perpetuo interesse, eamque tamquam doctrinam caelestem, qua par est reverentia et devotione audire atque discere debent omnes, qui in castri famulatu sunt, nimirum castrenses servitores, quos vulgo g r od z i an i e appellant: coci, pistores, calefactores, baiuli, portarii, vigiles denique omnes alii, qui in arce opus faciunt, quocumque nomine in ${ }^{\text {f }}$ castrensem familiam ${ }^{-\mathrm{f}}$ censeantur. Ex quibus omnibus, qui interesse neglexerit, vel tardius post campanae signum advenerit, aut sine causa, priusquam lectio finiatur, discesserit, grosso uno Polonico, quoties negligentiam huiusmodi commiserit, mulctabitur, nisi capitaneus vel vicecapitaneus mo-

d Nowina kop. 2 e Cirensi kop. 1-2 f-Castrense familia-f kop. 1-2 11 Jest to dowolne tlumaczenie kanonów Soboru Trydenckiego.

12 Sw. Cyryl biskup Jerozolimy, doktor Kościola (ok. 315-387), święto 18 marca.

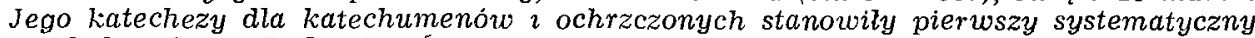
wyklad teologii (Radońskı: Swręci, s. 80). Calość lub część tego dziela przetlumaczył na jęz. polski Uchański (Estreicher: Bibliografia, t. XXXII, s. 8). Zastanawiajace, dlaczego siegnal do najstarszej literatury teologicznej.

13 Katechızm, o którym mowa, zw. Rzymskim ukazal się drukiem w r. $1566 z$ polecenia pap. św. Piusa V.

14 Teodoret biskup Cyru (Cyrrhus) $w$ Syrii, neśsięty i sympatyk nestorianizmu, $z m$. ok. 458 r. Czyżby Uchansk przetlumaczyl takze jego komentarz na Psalmy? Moze krytyczne stanowısko względem papiestwa kıerowalo myśli tego arcybiskupa do źródel Koścrola starozytnego.

${ }_{15}$ Dotad nie wiedzleliśmy o modlitwach autorstwa Uchańskzego, czy też wykladzue na ich temat $w$ jęz. ojczystym, uzywanym w kolegıacie low. 
derni et pro tempore existentes eundem ob certas causas iussu suo tardius venisse, vel inde citius, quam opportuit, discessisse, aut prorsus non interfuisse perhibeant. Quae mulcta, nisi eam statim penderit, de salario committentis defalcari et dimidiata pars vicecapitaneo moderno et pro tempore existenti tamquam exsecutori, reliquum vero omnibus lectionis illius auditoribus dictis exaequo dividendum cedere debet. Ad quae diligenter servanda vicecapitanei nostri moderni et pro tempore existentis conscientiam oneramus. Caeterum, ut praedictus lector non minus vitae innocentiae et morum integritatis exemplo, quam praelegendo pie instituat, volumus, ut censurae et animadversioni dumtaxat praelatorum et canonicorum Venerabilis Capituli dictae Ecclesiae Loviciensis perpetuo subsit. Quibus plenam potestatem facimus mores et vitam illius observandi [s. $314 w \mathrm{kop}$. 2] eundemque, quotiescumque deliquerit, pro qualitate culpae canonice emendandi. Donamus quoque, assignamus et tradimus donatione, assignatione firma et perpetua nomine anniversarii eidem Venerabili Capitulo quinque marcas Polonicales, in singulis quadraginta octo grossos computatos, quas dictus lector eidem Venerabili Capitulo ad festum Purificationis Beatissimae Mariae Virginis ${ }^{16}$ singulis annis [k. $\left.454 w k o p .1\right]$ ex decimis praedictis reddere et cum effectu persolvere perpetuis temporibus debebit. Ex quinque quibus marcis unam, quintam videlicet marcam, vicariis eiusdem ecclesiae dare capitulum ipsum debebit. Praedicti vero praelati et canonici cum omnibus vicariis singulis angariis vel Quattuor Temporibus singulis missas perpetuo decantari curabunt, quibus omnes praesentes, aliquo ex eorum numero celebrante, intererunt. Primam ${ }^{B}$ de Sanctissima Trinitate, alteram de Passione Domini, tertiam de Assumptione Beatissimae Mariae Virginis cum collecta pro peccatis, quartam vero pro Defunctis - in remedium animae nostrae et parentum atque amicorum nostrorum, praesertim Pauli Jassienski capitanei Chelmensis ${ }^{17}$ et etiam parentis eius Pauli de Jassieniecz castellani Sandomiriensis ${ }^{18}$ etc. $^{\text {h }}$ et eorum consanguineorum ac propinquorum. Quae omnia et singula praemissa vobis universis et singulis, quorum interest, intererit et interesse quomodolibet in futurum poterit, intimamus, insinuamus et notificamus, ac ad vestram et cuiuslibet vestri notitiam deducimus et deduci volumus per praesentes, harum quibus nostrum et dicti Venerabilis Capituli nostri ${ }^{19}$ sigilla sunt subappensa testi-

\footnotetext{
g Primum kop. 1-2 $\quad$ h nieczytelne $w$ kop. $1-2 \quad{ }_{1}$ Birolath kop. 2

16 Dzień 2 lutego.

17 Pawel Jasieński starosta chetmski, zm. $w 1$ pol. XVI w., syn następnego (Niesiecki: Herbarz, t. IV, s. 436).

18 Pawel $z$ Jasieńca (Ilżeckiego lub Soleckiego $w$ diec. sandomierskiej Jasıeński) h. Gozdawa albo Poronia (ok. 1430-1485) ostatnio kasztelan sand. $i$ starosta malborski, dowódca i dyplomata $z$ czasu panowania Kazımierza Jagiellończyka, m.in. wlaściciel miasteczka Uchane $w$ dek. hrubieszowskrm i protoplasta naszego prymasa (Niesiecki: Herbarz, t. II, s. 436-437.- PSB (K. Górski) t. XI (1964/65) s. 32).

${ }_{19}$ Chodzi o kapitulę metrop. gnieźnieñska.
} 
monio litterarum. Actum et datum in arce [s. $315 w$ kop. 2] nostra Loviciensi anno a Nativitate Domini millesimo quingentesimo sexagesimo quarto, indictione septima, die vero vigesima quarta mensis Decembris, pontificatu sanctissimi in Christo patris et domini, domini Pii divina providentia papae Quarti, anno ipsius quarto. Praesentibus venerabilibus, generosis ac nobilibus dominis: Gasparo Geschkaw abbate Olivensi ${ }^{20}$, Stanislao Dambrowski iuris utriusque doctore, archidiacono Gnesnensi, praeposito Volboriensi, Cracoviensi, Vladislaviensi ${ }^{21}$, Martino Gałczinski preposito Loviciensi, oeconomo nostro, Gnesnensi ${ }^{22}$, Francisco Crassinski archidiacono Calissiensi, Gnesnensi, Cracoviensi, Loviciensi ${ }^{23}$, Ioanne Piotrowski custode Loviciensi, Vladislaviensi ${ }^{24}$, Ioanne Radogosski Lanciciensi, Loviciensi ${ }^{25}$ canonicis et secretariis Sacrae Maiestatis Regiae, Matthia Czibulski thesaurario ${ }^{26}$, Floriano Jakaczki incisore ${ }^{27}$, Iacobo Birulth ${ }^{1}$ succamerario $^{28}[k$. $454 v$ w kop. 1$]$ Adriano Russoczki ${ }^{29}$, Stanislao Gultowski ${ }^{30}$, Matthia Barski $^{\mathrm{j} 31}$, Ioanne Modzelowski ${ }^{32}$, Ioanne Woynowski ${ }^{33}$, Sebastiano Magnu-

20 Kasper Geszkaw (Geschkau, Jeschke) z Chojnic, nobilitowany (ok. 1520-1584); studiowal $w$ zarazonym luteranizmem Lipsku $w$ l, 1541-1552, skąd powrócil do kraju 1556 ze stopniami bak. i mgra sztuk. W zwiazku z tym przez reszte zycia posadzany o herezje, ale dlatego tez doznawat ustawicznej opreki biskupa wlock. a potem arcybpa Uchańskiego, który w r. 1557 dopomógl mu objać nielegalnie opactwo Cystersów w Oliwie, $w 1562$ mianowal sufraganem we Wloclawku, nie uzyskawszy dlań prekonizacji, przed 1564 zdobyć stanowisko sekretarza król. W 1565 Zygmunt August oddal mu $w$ administracje bogaty klasztor Kartuzjan (w Kartuzach), w 1569 posiadl wreszcie Oliwe, w 1571-1574 byl z ramienia bpa wlock. Karnkowskiego oficjalem gdańskim. Za rzadów ostatniego Jagiellona i Stefana Batorego pelnit wiele funkcji politycznych $i$ dyplomatycznych, glównie $w$ sprawach Prus Król. Postać wybitna i jak Uchański kontrowersyına, godna monografii (S. Chodyńskl: Biskup sufragani wtoctawscy, Wloclawek 1906, s. 39-40.- P. Czaplewski: Wykaz oficjalów gdańskich $i$ pomorskich od 1467-1824 r., Toruń 1912, s. 46-47.- PSB (S. Bodniak) t. VII (1948/58) s. 410-411).

21 Stanislaw Dabrowski-zob. nr 27, przyp. 15.

22 Marcin Galczyński h. Sokola (1496-1573) studiowal w kraju i za granica uzysłujac drat ob. prawa. Kanonik łowickl, leczycki, gnieźnieński $w$ r. 1546, kustosz poznański $w$ 1552, starosta majatków kapituly gnieź. 1560-1572; prepozyt low., ekonom dóbr arcybiskupstwa, sekretarz król. - ostatnıe stanowiska przed 1564; uczestnik synodów (Korytloowski: Pralaci, t. II, s. 36-40.-Wieteska: Katalog, s. 44).

23 Franciszek Krasiński - zob. nr 27, przyp. 16.

21 Jan Piotrowski z Kujaw h. Korab (za Chodyńskim), a nie Jastrzębiec (jak ma Korytkowski), ksztalcil się w kraju 2 za granica. Kanonik chelmski przed 1561, wtoclawski $i$ kanclerz tamt. bpa Uchańskiego $w$ 1561, sekretarz król. $i$ kustosz lowicki przed 1564, kanonik gnieźnieński 1566, poznański, od 1567 tamt. kantor, od $1573 \mathrm{ku-}$ stosz, wcześniej już kanclerz bpa pozn. Konarskiego a następnie jego oficjal gen., zm. w r. 1586 (Korytkowskn: Pralaci, t. III, s. 221-222.— Chodyński: Katalog, s. 575576.- Wieteska: Katalog, s. 43).

25 Jan Radogoski i Radogolski, pewnie ze wsi Radogoszcz-dziś na ter. m. Eo-

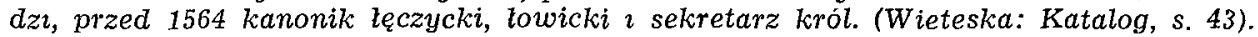

${ }_{20}$ Maciej Cybulski podskarbi kurii nadwornej arcybpa Uchańskiego.

27 Florian Jakacki krajczy dworu Uchańskiego.

28 Jakub Birult podkomorzy tegoż dworu.

29-38 Adrian Rusocki, Stanistaw Gultowski, Maciej Barski, Jan Modzelewskn, Jan Wojnowski, Sebastian Magnuszewski, Wojciech Solikowski, Jakub Chojeñski - klientela, przewaznie świecka, dworu wspom. prymasa. Por. Korytkowski: Arcybiskupi, t. III, s. 411 . 
szewski ${ }^{34}$, Alberto Solikowski ${ }^{35}$, Iacobo Chojeński ${ }^{36}$ et aliis aulicis et familiaribus nostris testibus circa praemissa. Transivit per manus Stanislai Dambrowski archidiaconi Gnesnensis in absentia cancellarii ${ }^{37}$.

\section{2}

Lowicz, 6 sierpnia 1583

Stanisław Karnkowski arcybiskup metropolita gnieźnieński, legat urodzony, prymas Król. Polskiego i pierwszy ksiązę powiadamia duchowieństwo archidiecezji gnieźnieńskiej, świeckie $i$ zakonne - aż do plebanów $i$ przeorów klasztorów włącznie, że postanowil zwolać synod diecezjalny, przewidywany $w$ ustawodawstwie kościelnym jeszcze co roku. Przedmiotem obrad będa naglace potrzeby Kościola diecezjalnego, zwlaszcza sprawy kultu i duchowieństwa. Na miejsce zgromadzenia prymas naznacza kościól kolegiacki $w$ Lowiczu, a dniem obrad 4 października 1583 roku - uroczystość św. Franciszka z Asyżu. Wszystkich wspomnianych wzywa pod sankcjami do stawiennictwa $w$ Lowiczu, a w końcu określa sposób publikacji swojego olcólnika (procesu).

Or. nie znany.

Kop. ADW, ABKP, II,18: Materialy synodalne $z$ XVI w., k. 8v-9.

Wyd. Synodus archidioecesana Gnesnensis praesidente Stanislao Karnkowski archiepiscopo [...] Lovicii anno Domini MDLXXXIII celebrata... Z. Chodyński [...] ed., Varsaviae [...] 1872, s. 14-18.

Stanislaus Karnkowski Dei et Apostolicae Sedis gratia Sanctae Ecclesiae Metropolitanae ar- [s. 15] chiepiscopus Gnesnensis, legatus natus et Regni Poloniae primas primusque princeps 1. Universis et singulis dominis praepositis, decanis, archidiaconis, custodibus, scholasticis, cantoribus, cano-

37 Mowa o kanclerzu kapituty czyli gnieźnieńskim, którym wtenczas był Hieronim Garwaski. Zob. nr 28, przyp. 13.

32. 1 Stanisław (z Karnkowa wsz kośc. $w$ dek. lipnoskim diec. wloctawskiej) Karnkowski h. Junosza (1520-1603) arcybiskup metropolita gnieźnieński, legat urodzony, prymas Król. Polskıego i pierwszy ksiazę, studiowal $w$ Krakowie $i$ Perugii; gdzle uzyskal drat ob. prawa. Pralat i kanonik kilku kapitul, sekretarz król. - od 1565 wielki, potem referendarz kor. Biskup wloclawski $w r$. 1567, koadiutor Uchańskıego $w$ Gnieźnie 1581, arcybiskup $\imath$ prymas 1582. W obydwu diecezjach zwolywat synody - jako metropolita takze prowincjalne, przeprowadzal wizytacje, zakladal seminaria duchowne: we Wloclawku 1568, w Kaliszu 1586, w Gnieźnie 1598, wydawal księgi liturgıczne. Jeszcze jako bıskup wtock. oglosil (1579) zbiór prawa prowincjalnego (Constitutiones synodorum metrop. ...), który nosi jego nazwę, oraz (1578) wybór swej korespondencji (Epistolae illustrium virorum...). Mówca, pisarz religigny $\imath$ polityczny; dyplomata, polityk, rzecznik praw Polski na Baltyku; $w$ r. 1570 zredagowal tzw. statuty (Polski) dla Gdańska noszqce jego imie. Koronowal królów i królowe, nalezy do najzasiuzeńszych hierarchów względem Kościola ^ Państwa (N. Korbut, 2, s. 313-317.A. Chmielowskn: Życiorys ks. S. Karnkowskiego arcybiskupa gnieźn., Warszawa 1885.- Korytkowsk : Arcybiskupi, t. III, s. 419-540, t. V, s. 312-313.- Szostkiewicz: Katalog, s. 93.- PSB (H. Kowalska) t. XII (1966/67) s. 77-82). 
nicis Ecclesiarum Metropolitanae Gnesnensis et Collegiatarum, necnon reverendis dominis abbatibus, prioribus, praepositis regularibus, plebanis et ecclesiarum parochialium rectoribus ac aliis, qui de iure vel consuetudine Synodo nostrae Dioecesanae interesse consueverunt, per et infra Dioecesim nostram Gnesnensem ubilibet consistentibus, ad quos praesentes nostrae pervenerint litterae, nobis in Christo dilectis salutem in Domino. Antiquissima Sanctorum Patrum auctoritas, ipsaque adeo sancta Concilii Tridentini ${ }^{2}$ decreta, provincialesque constitutiones nostrae praecipiunt, ut synodi dioecesanae singulis annis in quaque dioecesi celebrentur ${ }^{3}$. Quod nos cum in ipso statim regiminis nostri archiepiscopatus initio exsequi, totque malorum, quae nos urgent, avertendorum et sanandorum animi morborum, retinendique et augendi cultus divini modos et rationes communi omnium consilia conquirere, conquisitasque serio suscipere cuperemus atque conaremur; anno quidem superiore a graves Reipublicae occupationes publicique conventus necessarium hoc institutum nostrum impediverunt. Hoc vero anno, cum a publicis actionibus atque conventibus aliquam nobis vacationem Deus Optimus Maximus largiri dignatus sit, debito sollici- [s. 16] tudinis nostrae officio deesse non potuimus, quin ad ea, quae magnopere semper optavimus, quaeque rerum ecclesiasticarum rationes, populorum nobis creditorum salus, Deique gloria maxime postulant, totos nos converteremus. Nostraeque infirmitatis conscii, cum oculi plura quam oculus videant, multorumque consilia multam operentur salutem, Synodum Archidioecesanam indiceremus; atque coniunctis omnes studiis, consiliis et voluntatibus tam veteribus, quam recentibus malis obviam iremus, et ne ordo noster plus in dies capiat detrimenti, divina nobis suffragante gratia, diligenter solliciteque provideremus. Uti quidem eam, provincialibus inhaerendo constitutionibus, omnium commoditati consultum esse cupientes, Lovicii in Ecclesia nostra Collegiata die quarta mensis Octobris proxima, quae erit sancti Francisci Confessoris, celebrandam in Dei nomine indicimus per praesentes. Quae omnia et singula vobis omnibus et singulis suprascriptis, quibus interest, intererit aut quomodolibet in futurum interesse poterit, intimamus, insinuamus ac ad vestram et cuiuslibet vestrum notitiam deducimus indubitatam; atque eisdem in virtute sanctae oboedientiae et sub excommunicationis ac synodalibus poenis auctoritate nostra archiepiscopali districte praecipientes mandamus, quatenus in loco supradicto pro

32. a superiori wyd. 1 b desertatae wyd. 1

2 Sobór Trydencki - por. nr 31, przyp. 2.

3 Synod diecezjalny powinien się odbywać corocznie, najlepiej po przeprowadzonych wizytacjach kościolów, za wyjatkiem lat, kiedy co trzeci rok mial być zwolany synod prowincjalny (M. Morawski: Synod diecezjalny $w$ dawnej Polsce, Wloclawek 1937, s. 6-8.- S. Librowski: Wizytacje diecezji wloclawskiej, cz. 1, t. 1, z. 1, Lublin 1964, s. 102-105). 
die et tempore designatis in habitibus decentibus compareatis, nobiscum de rebus ordinis ecclesiastici iam fere periclitantis consulturi delibe[s. 17] rationemque suscepturi. Certificantes omnes et singulos suprascriptos, quod sive in praedicta synodo comparuerint sive non, nos nihilominus ad ipsius celebrationem, dante Domino, procedemus et ea, quae utilitati ecclesiarum Archidioecesis nostrae fore videbuntur, constituemus contumatia ipsorum in aliquo non obstante, poenis quoque contra absentes ex constitutionibus synodalibus extensis. Volumus insuper et sub poenis praescriptis praecipimus, ne de praemissis aliquan ignorantiam quisque sibi praetendat, ut praesentem processum per affixionem valvis Ecclesiarum Metropolitanae et Collegiatarum Archidioecesis nostrae prius publicatum, vel eius transumptum sub sigillo alicuius officialis nostri editum, unus ad alium rectorem ecclesiae sibi vicinioris, quanto citius poterit, deferat. Circa exsecutionem vero simul quilibet vestrum nomina ecclesiarum sibi vicinarum asscribat, quae vel desertae vel ab haereticis occupatae fuerint, et item quae legitime institutos parochos non habeant; quarum priores, tam videlicet haereticae quam desertae ${ }^{\mathrm{b}}$, praetermittı omnino debent et ulterius ad catholicum usque sacerdotem remitti, ultimus vero ipsum nobis aut officiali nostro territorii quisque sui repraesentet. In quorum omnium et singulorum fidem et testimonium sigillum nostrum praesentibus est subimpressum. Actum et datum in arce nostra Loviciensi sexta mensis Augusti anno Domini millesimo quingentesimo octogesimo tertio, Caspa[s. 18] rus de Cobelino Curıae notarius ${ }^{4}$, de mandato suae reverendissimae paternitatis subscripsit.

Lowicz, 13 kwietnia 1587

Stanislaw Karnkowskı arcybiskup gnieźnıeński, legat urodzony, prymas Król. Polskiego i pierwszy ksiażę ${ }^{1}$, pragnac wskrzesić $w$ kolegiacie towickiej staly urzed penitencjarski (erygowany tam w r. 1510) upadty na skutek wygaśnıęcia większej części jego uposażenia, dodaje do poprzedniego - za zgoda kapituly metrop. gnieźnieńskiej - na utrzymanie każdorazowego penitencjarza dziesięcinę snopowa ze wszystkich zbóż we wsi arcybiskupiej Dzierzgów (na terenie par. Belchów K. Lowicza).

1 Kasper $z$ Kobylina ( $w$ dek. krotoszyńskım archıdiec. poznańskıej) notarıusz kurii zadwornej Karnkowskzego; od $r 1603$ kanonik towıckı, zm. $w 1612$ (Wieteska: Katalog, s. 55).

33. 1 Stanislaw Karnkowsk - zob. nr 32, przyp. 1. 
Or. nie znany.

Kop. 1 -wspólcz. AAG, B7: Kopiariusz z lat 1585-1604 (Karnkowskiego, daw. 4), k. 21v-22. Tytul: Gratia pro ordinario paenitentiarıo Ecclesiae Colleg1atae Louiciensis.

2. AKL: Kopiariusz Śladeckıego sprzed r. 1810, s. 329-331, wyic. $z$ uwierz. odpisu sporz. $w$ r. 1774 przez $M$. Podkowskiego not. publ. z ustan. pap. $i$ kap. gnieźn. z kop. 1. Tytul: 1587. Prıvilegium super decima de villa Dzierzgow pro poenitentiario.

Reg. Librowskn: Sumarusz, nr 68.

Uw. 1. Odnośnie fundacji 2 erekcji beneficjum penitencjarskiego $w$ r. 1510 zob. Librowski: Sumariusz, nr 28-29.

2. Przydzielenie dziesięciny z Dzierzgowa penitencjarzowi dowodzi, $\dot{z} e$ fundacja katechety $z r .1564$ (Uchañskiego - por. nr 31) przestata istnieć.

Lowicz, r. 1592-1593

Stanislaw Karnkowski arcybuskup gnieźnieński itd. ${ }^{1}$ albo z jego upoważienia oficjal lowicki - przypuszczalnie Stanislaw Roguski ${ }^{2}$ eryguje $w$ kolegiacie lowickiej oltarz (i oltarię) pw. Najśw. Maryi Panny, ufundowany przez kogoś z rodziny Strzyżykowskich z Lowicza.

Or. nue znany.

Wp. 1 pod an. $13 \mathrm{~V} 1592$ do akt arcybpa Karnkowskiego, spalonych w r. 1944 (Regesty zapisek, s. 93).

2 pod dn. $5 \mathrm{~V} 1593$ do akt tegoz prymasa (Regesty zapisek, s. 94).

Uw. $Z$ powodu niewystarczające bazy źródtowej oltarza tego nie potrafie umıejscowić we wspom. kolegracie. Być może, iz beneficjum to wkrótce podupadto $\imath$ weszlo $w$ r. $1602 w$ slclad nieco ogólnıejszej fundacji uczynionej przez samego Roguskıego - zob. nr 38 .

Stanislaw Karnkowskı arcybiskup gnieźnıenski itd.1 wciela beneficjum parafialne $w$ Zdunach $^{2}$ do uposażenia konwentu Dominikanów ${ }^{3}$ w Lowiczu.

34. i Stanzslaw Karnkowskı - por nr 32, przyp. 1.

2 Stanislaw Rogusk h. Habdank kanonik towick przed 1593, potem tamt. kustosz 2 oficjat - na pewno $w$ r. 1500, fundator oltarza $w$ tzw kaplicy proboszczowskiej wym. kolegiaty, zm. przed 1612 (Wieteska: Katalog, s. 49).

35. 1 Sianisiaw Karnkowski - zob. nr 32, przyp. 1.

2 Wieś Zduny pod Lowıczem - por nr 18, przyp. 6.

3 Klasztor Dominikanów zalożono w Eowiczu na przestrzeñ 1. 1400-1414 -. zob. $n r 4$. 
Or. nie znany.

Wp. pod dn. 12 VI 1600 w akta arcybpa Karnkowskiego, spalone $w$ r. 1944 (Regesty zapisek, s. 102).

Uw. Par. Zduny inkorporowat w r. 1522 i 1528 prym. Laski do mensy archidiakona lowickiego - por. nr 18 i 20. Z nin. dokumentu wynika, że wspom. pralat gej nie utrzymal.

Stanislaw Karnkowski arcybiskup metropolita gnieźnieński, legat urodzony, prymas Król. Polskiego i pierwszy ksiażę wspominają, że już przed kilku laty polożyl fundamenty pod Bractwo Milosierdzia i zarazem Bank Pobożny $w$ Lowiczu oraz polaczyl $z$ nim szpital o tejże nazwie, posiadajacy od niego pewne place $i$ domy; że następnie zrzekl się na jego korzyść czynszu rocznego 52 flor. pol. z wydzierżawionego wójtostwa Zabostów Duży, należacego do jego mensy; ostatnio zaś nabyl w Lowiczu, przy rynku Starego Miasta, obszerny plac, na którym wybudował kamienicę; oprócz tego, równiė̇ za wlasne pieniadze, kupit dla tejże instytucji we wsi Zielkowice lan pola $z w$. Zydowski $i$ wlaczyl go do wspom. posagu. Wreszcie niniejszym aktem eryguje kanonicznie owa instytucje. Najpierw przeto, za zgoda kapituly metrop. gnieźnieńskiej, dodaje do wym. uposażeń lan pola zw. Trojanowski we wsi arcybiskupiej Korabka, przynoszacy 10 flor. rocznego dochodu. Wlaścicielami tego wszystkiego czyni Karnkowski biednych. Podobnie za przyzwoleniem wspom. kapituly zwalnia tychże ze wszystkich oplat na rzecz swojej rezydencji $w$ Lowiczu i samorzadu miejskiego, zapewnia im bezplatny przemial wszelkiego ziarna $w$ swoim mlynie lowickim oraz potrzebne napoje z wlasnych wytwórni propinacyjnych, przyznaje konieczne drzewo z okolicznych lasów arcybiskupstwa na remonty, odbudowe $i$ opał. Administracje $i$ opieke nad tak wyposażona $i$ zatożona przez siebie instytucja powierza prymas kapitule kolegiackiej $w$ Lowiczu, zezwalajac nawet na wydzierżawianie owych nieruchomości, jeżeli będzie tego wymagalo dobro biednych.

Or. ozn. nrem 17 (57) byt przed r. 1939 w AAW (nota ks. Kwiatkowskiego na s. 340 koprariusza Sladeckiego).

Kop. 1 - wspótcz. AAG, B7: Koprariusz z lat 1585-1604 (Karnkowskiego daw. 4), k. 192-194. Tytut: Privilegium fundationis Hospitalis et Fraternitatis Misericordiae in civitate Loviciensi.

2. AKL: Kopiariusz Sladeckiego sprzed r. 1810, s. 340-346. Tytut: 1601. Privilegium super lapideam in Lowicz, advocatiam in Zabostow, mansum in Korabka etc.

Reg. Librowski: Sumariusz, $n r 71$. 
Wzm. Korytkowskn: Arcybrskupi, t. III, s. 517-518.

Lit. Warężak: Mons pietatis $w$ Lowiczu, w: Studia $z$ historii spolecznej $i$ gospodarczej pośwıęcone prof. dr. Franciszkowi Bujakowı, Lwów 1931, s. 285-315, rés. s. 610-612.

Uw. Odpis dokumentu wyst. przez Karnkowskıego, moca którego tenże darowuje roczny czynsz wynoszący 52 flor, rocznie $z$ dzierzawy wójtostwa Zabostów Duzy dla Bractwa Miłosierdzia w Lowiczu, znajduje się w kopiariuszu Śladecklego na s. 331-336, a jego regest w-Librowski: Sumariusz, nr 69.

In nomine Domini amen. Ad perpetuam rei memoriam. Inter reliquas christiani hominis virtutes munificentia ac liberalitas erga egenos et pauperes primas sibi partes venditare ${ }^{a}$ videtur ipsius Salvatoris Domini nostri Iesu Christi testimo- [k. $192 v w k o p .1]$ nio, qui cupiens eam virtutem nobis reddere commendatam, ex inhaustae pietatis suae erga nos fonte ea omnia, quaecumque uni ex pauperibus et egenis ab aliquo praestantur, sibi praestari attestatus est, eiusdem virtutis nomine omnibus eam amplectentibus aeternae vitae praemia polliceri dignatus est. Hinc est, quod nos Stan1slaus Karnkowski Dei et Apostolicae Sedis gratia Sanctae Ecclesiae Metropolitanae Gnesnensis archiepiscopus [s. $341 w$ kop. 2], legatus natus, Regni Poloniae primas primusque princeps etc. ${ }^{1}$ pro nostro perpetuae laudis et gloriae divinae propagandae studio zeloque et singulari erga egenos et pauperes pietatis affectu, quo semper divina gratia flagravimus flagramusque, cupientes tanti praemii esse participes; posteaquam Fraternitatem, ut vocant, Misericordiae et Montis Pietatis in civitate nostra Loviciensi iam alias annos ante aliquot instituissemus, illique hospitale ${ }^{2}$ certis areis et domibus, nostra propria pecunia comparatis, adiunxissemus: primo quidem pro reditibus ac in dotem $\mathrm{ad}^{\mathrm{b}}$ advocatiam in villa nostra archiepiscopali Zabostow Maius ${ }^{3}$ dicta, censumque annuum quinquaginta duorum florenorum Polonicalium de eadem advocatia provenientem, unum deinde agri ${ }^{c}$ mansum Trojanowski ${ }^{4}$ nuncupatum in villa nostra Korabka ${ }^{5}$ dicta, censumque decem florenorum annuum ex eodem agro provenientem, cum consensu et sub ratihabitione venerabilium fratrum nostrorum praelatorum et canonicorum totiusque Capituli Ecclesiae nostrae Metropolitanae Gnesnensis ${ }^{6}$ eidem hospitali iure perpetuo dedimus, donavimus, univimus incorporavimusque, prout de praemissis privilegia desuper confecta atque fraternitati

36. a vendicare kop. 1-2 b ac kop. 2 c brak $w$ kop. 1 d Żydow-

36. 1 Stanistaw Karnkowskı - zob. nr 32, przyp. 1.

2 Szpital nosil równiez nazwę Milosierdzia (Bozego), ale o jego kaplicy nuczego nıe wiadomo.

${ }^{3}$ Zabostów Duży, wieś w par. Kompına dek. lowıckıego kolegiaty (Rocznik 1958, s. 304).

${ }_{4}$ Nazwy tego lanu literatura druk. ne przekazuje.

5 Korabka, wieś (załozona przez arcybpa Łaskıego) na ter par. Bolimów w dek. kolegiackim Lowicza (Rocznik 1958, s. 302.-Waręzak: Stownik, cz. II, z. 1, s. 155-156).

6 Por $n r$ 2, przyp. 8. 
tradita librisque actorum Curiae nostrae inserta testantur ${ }^{7}$. Postmodum vero eodem pietatis studio ducti, quanto maiores in munere hoc impari sane humeris nostris diebus nostris divina benignitas benedictiones impartitur, tanto amplius gratitudinem nostram apud selectos Christi ac dilectos nimirum amicos pauperes testari contendentes, certa area in circo Fori Loviciensis Antiquae Civitatis, inter domos lapideas famati [s. $342 w$ kop. 2] olim Iacobi Strzeżyk ${ }^{8}$ ex una et Alexii Kapciarz ${ }^{9}$ ab altera partibus sita, propria nostra pecunia empta et comparata, domum lapideam in eadem propriis nostris sumptibus ab ipsis fundamentis latere ereximus et extruximus, adiunctisque sufficientibus aedificiis complevimus et omnibus requisitis apparavimus adornavimusque. Praeterea unum agri mansum in tribus campis in villa Zelkowice ${ }^{10}$ nuncupata Żydowski ${ }^{\text {d }}{ }^{11}$ dictum, pecunia nostra similiter comparatum et emptum, prout [k. 193 w kop. 1] de resignationibus emptionibusque huiusmodi acta advocatialia civitatis nostrae Loviciensis fidem faciunt ${ }^{12}$, cum omnibus pratis, pascuis, areis, hortis, ad dictum agrum spectantibus et pertinentibus, praefatae domui adiunximus, univimus incorporavimusque. Insuper ut maius emolumentum ac utilitas ex supradicta domo eique adiunctis bonis hospitali, in eoque perpetuo pauperibus sustentandis proveniat, eiusdem lapideae eorumve ${ }^{\mathrm{e}}$ bonorum dominos ${ }^{f}$ proprietarios atque adeo ipsos ex quocumque titulo possessores fecimus, liberos et immunes ab omnibus et singulis censibus, oneribus, datis et pensionibus quibusvis, quos et quas nobis nostrisque successoribus ex dicta lapidea bonisque illi annexis, sive nomine propinationis Piątkoviensis ${ }^{13}$ et cuiusvis alterius generis cerevisiae, vini, mulsi, cremati et quorumvis aliorum liquorum, sive quacumque alia ex causa solvere et pendere tenerentur essentque asstricti; tum et a solutione braseorum tam cerevisialium, quam cremati, ob liberam eorum in molendino Loviciensi ${ }^{14}$ molitionem (quam praesentibus praefatae lapideae eiusque quocumque nomine et titulo [s. $343 w k o p .2]$ possessoribus concedimus perpetuo, ita ut a nullius unquam frumenti aut grani, tritici videlicet siliginis et aliorum in molendino nostro molendorum mensuras solvere et pendere teneatur); necnon

skie kop. 2 c commune kop. 1 f dommosque kop. 1 g brak $w$ kop. 1-2

7 Z owych dokumentów żnamy tylko odnoszący się do Zabostowa Duzego - zob. wyzej $u w$.

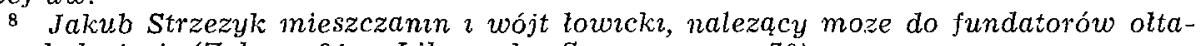
rza $w$ kolegiacie (Zob. nr 34.-Librowskn: Sumarnusz, nr 70).

I Aleksy Kapciarz mieszczanin w Lowiczu.

10 Zielkowice, wieś $w$ par. kolegiackiej Łowıcza (Rocznik 1958, s. 307).

11 Nazwy tego lanu nie podaje lit. druk.

12 Alkta wójtowskie $m$. Eowıcza sa bardzo zdziesıatkowane 2 rozproszone.

13 Propinacje pıwa $w$ miasteczku Piatek pod Łęczyca przekazal arcybp Karnkowskı $w$ r 1599 kapitule łowickiej razem z wójtostwem n. Łowıcza (Librowskı: Sumarıusz, nr 70).

14 O miyne arcybiskupim na rz. Bzurze pod Lowiczem sq liczne wzmianki w zachowanym kopıaruszu kapıtuly low. (Librowskı: Sumariusz). 
ab omnibus oneribus [ $\mathrm{et}^{\mathrm{g}}$ ] solutionibus tam nostris castrensibus, quam civilibus vulgo $\mathrm{szosz}$ et $\mathrm{domowe}$ appellatis, ${ }^{\mathrm{h}}$-ac a quibusvis aliis omnibus quocumque nomine appellatis ${ }^{-\mathbf{h}}$ et appellandis, prout de consensu et ratihabitione venerabilium fratrum nostrorum dominorum praelatorum et canonicorum totiusque Capituli Ecclesiae nostrae Metropolitanae Gnesnensis reddimus et facimus temporibus perpetuis per praesentes. Praefatam domum lapideam, tamquam in pium usum conversam, datam et donatam, libertati et immunitati ecclesiasticae iisdem perpetuo ascribentes atque pro ascripta haberi volentes. Licebit nihilominus praedictae lapideae domus locationis seu alio quovis titulo, possessori pro tempore existenti, omnibus iuribus, libertatibus, privilegiis et immunitatibus omnibus et singulis tam in parte, quam in toto domi $[s]$ in civitate et ubivis extra gaudere, iisque plene utifrui, quibus alii cives et incolae civitatis nostrae Loviciensis ab antiquo et ad praesens gaudent ac in posterum quovis nomine gaudebunt. Quoties vero praedictae domus lapideae aedificia in parte aliqua reparatione vel infelici aliquo, quem Dominus Deus avertat, casu restauratione indigebunt omni tempore et vice, ad talem necessariam reparationem seu restaurationem liberam in silvis borrisque nostris archiepiscopalibus [k. $193 v w$ kop. 1] Lovicio vicinioribus seu alias opportunioribus ligna et trabes excidendi ${ }^{~}$ et evehendi libere absque ulla pensione et impedimento damus, promittimus, donamus et concedimus perpetuo [s. 344 w kop. 2] sub consensu itidem et ratihabitione venerabilium fratrum nostrorum dominorum praelatorum et canonicorum ac totius Venerabilis Capituli ${ }^{j}$ Ecclesiae nostrae Metropolitanae Gnesnensis. Atque hanc lapideam, ut praemissum est, a nobis a fundamentis extructam, una cum bonis illi per nos unitis, agro videlicet cum suis attinentiis, iuribusque, libertatibus ac immunitatibus eidem lapideae concessis, datis et annexis, cum omni iure, proprietate ac dominio praemissorum omnium et singulorum superius nominatae Fraternitati Misericordiae eiusque nominis Hospitali dandam, donandam, concedendam, resignandam et incorporandam duximus, prout damus, donamus, concedimus, resignamus incorporamusque in Dei nomine hisce litteris nostris, nihil prorsus proprietatis ac dominii in dicta lapidea eiusque area, seu aliis bonis omnibus et singulis supranominatis pro nobis nostrisque successoribus in iisdem bonis reservantes, sed illud integre ad dictam Fraternitatem Misericordiae et Hospitale transferentes et transfundantes ita nimirum, ut eadem fraternitas lapidea praefata et alia bona supraspecificata ex nunc et deinceps temporibus perpetuis iure haereditario teneat, habeat. possideat illisque utifruatur. Volumus denique atque ita litteris hisce nostris staturmus, ordinamus ac disponimus perpetuo, ut quemadmodum provisionem, administrationem, curam et protectionem praefatae fra-

$\mathrm{h}-\mathrm{h} \quad$ brak w kop. $2 \quad 1$ excindendi kop. 1-2 J awukrotnie $w$ kop. $2 \quad \mathrm{k}$ qui- 
ternitatis ac hospitalis Venerabili Capitulo Ecclesiae Collegiatae Loviciensis dedimus, tradidimus et concessimus. Ita eiusdem quoque lapideae domus, ut praemissum est, per nos erectae, eidem fraternitati incorporatae cum omnibus et singulis [s. $345 w$ kop. 2] aedificiis, agris, hortis, pratis, proventibus, iuribus, libertatibus ac immunitatibus, quibusvis omnibus attinentiis et pertinentiis supremum regimen, administratio, provisio, cura et protectio penes idem Venerabile Capitulum Loviciense sit remaneatque temporibus perpetuis. Plenam et omnimodam praefato Venerabili Capitulo Loviciensi dantes et concedentes facultatem de eadem lapidea disponendi, eamque in rem praefatae fraternitatis quibusvis personis sub censu annuo ad usum et pauperum in dicto fraternitatis hospitali alendorum convertendi, adiectis quibusvis ${ }^{\mathrm{k}}$ melioribus, [si ${ }^{1}$ ] videbitur, conditionibus, ad breve vel ad longissimum etram tempus locandi, eoque locationis titulo dandi et tradendi, obligantes omnes in universum ac eorum quomodolibet perpetuo prospiciant, contendant et enitantur, ut nostrae huic donationi, concessioni et ordinationi in omnibus clausulis et punctis singulis iuxta voluntatem et intentionem nostram fiat satis, eosque cui vel quibus praefatam $[k .194 w$ kop. 1] domum lapideam locaverint vel quovis titulo concesserint, in iuribus, libertatibus, immunitatibus eidem domui a nobıs concessis conservent, tueantur atque defendant. Si quis autem praemissae nostrae erectioni, donationi, concessioni, resignationi, incorporationi, transfusioni et translationi ac libertationi, seu alias praemissis omnibus et singulis tam in toto, quam in parte aliqua contradicere praesumpserit, aut aliquo temerario ausu ordinationem hane nostram frangere, violare aut aliqua ratione impedire attentaverit ${ }^{1}$, ei indignationem Dei Praepotentis et sempiternam maledictionem ab ıpso impiétatis ultore et iusto temeritatis vindice, Deo Potenti imprecamur. Ad [s. $346 w$ kop. 2] praemissorum autem robur firmiusque ac valiturum perpetuo testimonium praesentes litteras manu nostra subscripsimus sigilloque nostro ac Venerabilis Capituli Ecclesiae nostrae Metropolitanae Gnesnensis fecimus communiri. Actum et datum Lovicii anno salutis millesimo sescentèsimo primo, die vigesima secunda mensis Ianuarii. Praesentibus reverendis ac illustribus dominis: domino Martino Karnkowski Gnesnensi et Loviciensi decano, custode Vladislaviensi, Cracoviensi canonico ${ }^{15}$, Vincentio de Seve iuris utrisque doctore, praeposito Lascensi, ${ }^{\text {m- }}$ archidiacono Gnesnensi, Loviciensi canonico ${ }^{16}$, Iacobo Lempicki iuris utriusque doctore, decano

bus kop. $1 \quad l$ dodal wyd. $\quad \mathrm{t}$ attentaverint kop. $1-2 \quad \mathrm{~m}-\mathrm{m}$ brak $w$ kop. 2

15 Marcin Karnkowski h. Junosza (1554-1631), synowiec prymasa, kustosz wloclawski $w$ r. 1580, dzıekan lowickı, kanonik gneż́neński 1583, jeszcze tr tamt, kanclerz, 1588 dziekan, kanonik krakowski 1592, sekretarz król. (Kętowskı: Katalog, t. III, s. 107108.- Korytkowskı: Prakaci, t. II, s. 228-230.- Chodyńskı: Kaialog, s. 287.-Wieteska: Katalog, s. 55).

16 Wincenty de Seve szlachcic francuski (ok. 1557-1611), studiowal $w$ Rzymre, gdzıe uzyskal drat ob. prawa. Spokrewnony z rodzina Laskich, zostal $w$ r. 1582 prepozytem kolegiaty $w$ Lasku, 1593 kanonikiem lowıkim, po $r 1601$ prepozytem tant. 
Lanciciensi-m $^{-m}$, archidiacono Loviciensi, Gnesnensi canonico, Curiae nostrae cancellario ${ }^{\mathbf{1 7}}$, Sventoslao Sarnowski cancellario Gnesnensi, Lanciciensi, Loviciensı canonico, praeposito Siradiensi ${ }^{18}$, Felice Lupszinski Gnesnensi, Lanciciensi, Loviciensi canonico ${ }^{19}$, Bartholomaeo Mirczinski Gnesnensi canonico, praeposito Squiernieviensi ${ }^{20}$, Stanislao Roguski custode Loviciensi ${ }^{21}$, Nicolao Squiernievio iuris utriusque doctore, Loviciensi canonico, parocho Pczionoviensi ${ }^{22}$, Sebastiano Makowski iuris utriusque doctore, custode Lanciciensi, Loviciensi canonico ${ }^{23}$, Vincentio Oczko philosophiae et medicinae doctore, canonıco Loviciensi, plebano Conariensi ${ }^{24}$, Martino a Ilow plebano Gluchoviensi ${ }^{25}$, necnon generosis dominis: Ioanne Domaniewski dapifero Lanciciensı, Curiae nostrae marsalco ${ }^{n 26}$, Matthia Gosczminski $^{\circ}$ capitaneo Loviciensi ${ }^{27}$, Laurentio Kawecki ${ }^{28}$, Alberto Kanigowski ${ }^{29}$

2 par. Koścıan, archıdiakonem gnıeźnıéskım 1594, prepozytem lęczyckım przed 1605; $w r .1603$ byl adminıstratorem archidiec. gniezn. Wizytował kościoly, bral udzıal $w$ synodach $i$ sejmach, odbyt 5 podrózy dyplomatycznych do Rzymu. Nobilitowany $w r$ 1607; swoja bogata bibliotekę pozostawil kapitule laskiej, która późñej odsprzedala ja katedrze gnieźn. (Korytkowski: Pralacı, t. III, s. 463-474.- H. Rybus: Biblioteka Kolegiaty Łaskiej, Łódź 1939, s. 6-9.- Wieteska: Katalog, s. 48).

17 Jakub Lempicki $h$. Junosza (1545-1608) studiowal w kraju $\imath$ za granuca, dr ob. prawa; kanonik gnıeźnieński w r. 1584, kanclerz kurii arcybpa Karnkowskiego, se-

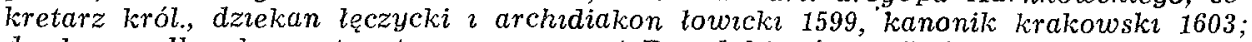
dziekan wolborski, proionotariusz ap., opat Benedyktynów w Lubınıu 1606 (Letowski: Katalog, t. III, s. 292.- Korytkowski: Pralaci, t. II, s. 522-524.- Wieteska: Katalog, s. 47).

18 Swiętostaw Sarnowslı $h$. Jastrzębıec studiowal w Krakowıe $\imath$ za granıca, prepozyt par. Skierniewnce $\imath$ Sieradz po r. 1582, kanonik lowıckı przed 1600, dziekan

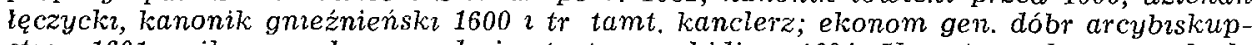
stwa 1601, wikariusz kap. 2 administrator archidiec. 1604. Uczestnıczy $w^{\prime}$ synodach, seymach $i$ trybunatach, zm. w 1625 (Korytlowskl: Prakach, t. III, s. 447-460.- Wieteska: Katalog, s, 50).

19 Feliks (Szczęsny) Lupsiński (a nie Lipczyńskı albo Liupczyńskı - jak maja. Korytkowski 2 Wieteska - z Lubsina w par. Piotrków Kujawski) h. Labędź, kanonik lowickı $w$ r 1593, dzlekan lęczyckı, kanonik gnieźnieńskı 1599, zm. w 1612 (Korytlowski: Prałaci, t. II, s. 445-446.- Wieteska: Katalog, s. 48-49).

20 Bartímıej Mirczyński pleban par. Będków, kanonik gñeźnıeńskı w $r$ 1599, prepozyt par. Skierniewice, zm. w 1613 (Korytkowskl: Pralaci, t. III, s. 12).

21 Stanistaw Roguski - zob. nr 34, przyp. 2.

22 Mikołaj Skıerniewita (ze Skierniewic) dr ob. prawa, kanonik lowicki w $r .1599$, potem tamt. oficjal, pleban par. Pszczonów przed 1601, zm. $w$ 1626 (Wieteska: Katalog, s. 49-50 - wspom. autor dubluje $w$ tejze osobie nieco starszego Stanzslawa ze Skierniewıc, kan. sand.).

${ }_{23}$ Sebastian Makowski dr ob. prawa, kanonik lowncki przed $r$ 1600, kustosz leczycli przed 1601, zm. w 1619 (Wieteska: Katalog, s. 50).

21 Wincenty Oczko (z Warszawy) studiowal w Krakowze \& Padwie, dr filozofii $\imath$ medycyny, kanonik lowick ok. 1593, pleban par Konary $w$ dek. Warka przed 1601, kanonik gnieźnıeńskı w 1605, zm, w 1626 (Korytkowski. Pralaci, t. III, s. 114-116.Wieteska: Katalog, s. 50-52).

${ }_{25}$ Marcin $z$ Ilowa ( $w$ dek. sochaczewskim) pleban $w$ Gluchowie $w$ dek. skierniewickin przed 1601.

2.) Jan Domaniewskı $h$. Rolicz, stolnik lęczyckı, marszalek kurii nadwornejarcybpa Karnkowsliego przed 1601; jako kleryk byl on w l. 1587-1590 kanonikiem gnieżnieńskim $~$ poznańskim (Korytkowski: Prałaci, t. I, s. 229-230).

27 Macıej Goścımiński h. Grabıe, starosta arcybıskupi lowick przed 1601. 
Curiae nostrae praelatis et familiaribus. Stanislaus ${ }^{\mathrm{p}}-a$ Karnkow $^{-\mathrm{p}}$ archiepiscopus Gnesnensis etc. manu propria scripsit. Transivit per manus Martini Karnkowski decani Gnesnensis et protunc generalis capituli praesidentis ${ }^{30}$ [qui ${ }^{\text {q] }}$ manu propria scripsit.

Lowicz, 4 maja 1601

Notarıusz kurii zadwornej arcybiskupa gnieźnieńskiego Stanislawa Karnkowskiego stwierdza, że - w następstwie czynności prawnych Tomasza z Uniejowa plebana par. Boleszczyn, plenipotenta Anny Roszkowej ( $z$ Lowicza) - tenże prymas erygowal $w$ osobne beneficjum kościelne czyli kapelanię oltarz wystawiony przez wspomniana w kaplicy (rodowej) Roszków, istniejącej (z dawna) w kościele par. Sw. Ducha w Lowiczu, dedykowany ku chwale Bożej a pt. św. Anny. Arcybiskup jednocześnie zatwierdzil umowę wstępna, zawarta 22 stycznia tr. pomiędzy fundatorka a kapitula lowicka, dotyczaca uposażenia kapelana wynoszacego 20 flor. pol. rocznie $i$ odprawiania nabożeństw przy oltarzu. Na wystapienie wladz Bractwa Strzeleckiego $z$ Lowicza, korzystajacego tradycyjnie $z$ owej kaplicy, prymas zagwarantowal mu dalsze odprawianie tamże jego uroczystości. Utrzymanie kapelana i patronat nad oltaria należy do fundatorki, a po jej śmierci przechodzi na kapitule lowicka. Arcybiskup polecil swej kurii, by wydala zainieresowanym stronom odpowiednie dokumenty a kapelanowi przypomniał o wiernym wypelnianiu obowiazków.

Or. nie znany.

Wp. pod dn. $4 \mathrm{~V} 1601$ do akt arcybpa Karnkowskiego, zniszczonych w r. 1944 (Regesty zapisek, s. 104).

Kop. AKL: Kopiariusz Sladeckiego sprzed r. 1810, s. 347-351. Tytut: 1601. Erectio altarıs in Capella Roszkoviana. Sti Spiritus. Sladecki opuścil ze swojej podstawy źródtowej nazwisko wspom. notariusza.

Reg. Librowski: Sumariusz, $n r 72$.

Wzm. Oczykowski: Przechadzka, s, 131 (,Kaplica Miejska, dawniej Roszkiewiczowska").

Anno Domini millesimo sescentesimo primo, die Veneris quarta mensis Maii a venerabilis dominus Thomas Unieioviensis ecclesiae parochialis Bo-

\footnotetext{
n mareschalco kop. $2 \quad$ o Goścımiński kop. $2 \quad$ p-p Karnkowski kop. $2 \quad$ q dodat $w y d$.

28-29 Wawrzyniec Kawecki $\imath$ Wojciech Kanigowski familiaresi dworu prym. Karnkowskiego, których obok innych wylicza Korytkowski (Arcybrskupı, t. 111, s. 526-527 $w$ przyp.).

30 Prat. M. Karnkowskı przewodniczyl zebranıu gen. kapıtuly gnieźn., na którym nin. dokument uzyskal jej potwierdzenie.
}

37. a Mal kop. b dodal wyd. ${ }^{\mathrm{e}-\mathrm{c}}$ uzupelnit wyd. a edit kop. 
leszczynensis parochus ${ }^{1}$, honestae Annae Roszkowa ${ }^{2}$ principalis [et ${ }^{b}$ ] legitimus procurator, exhibitis citationis in vim cridae litteris ad dictae suae principalis instantiam, ex cancellaria illustrissimi ac reverendissimi domini archiepiscopi Gnesnensis memorati [ ${ }^{-}$Stanislai Karnkowski $\left.{ }^{-c}\right]^{3}$ ad effectum infrascriptum, contra omnes et singulos coniunctim vel divisim sua interesse putantes editis ${ }^{d}\left[\mathrm{ac}^{\circ}\right]$ debite publicatis ${ }^{\mathrm{f}}$, subsequenter contumaciam omnium et singulorum ius et interesse aliquod ad erectionem altaris in Capella Roszkow ${ }^{4}$ dicta in Ecclesia Parochiali Loviciensi Sancti Spiritus ${ }^{5}$ consistentis se habere praetendentium debite citatorum, non tamen comparentium per se vel per suos aliquos procuratores, contentaque litterarum citationis in vim cridae minime impugnantium [accusavit ${ }^{\mathrm{g}}$ ], petens ipsos et quemlibet illorum contumaciam pronuntiari; eorumque contumacia ${ }^{\text {h }}$ minime obstante ${ }^{1}$ altare in capella praedicta per praefatam Annam Roszkowa suam principalem ornatum, certoque annuo viginti florenorum Polonicalium, in quemlibet florenorum grossos triginta computando, censu quadringentorum florenorum eiusdem numeri et monetae principali summa apud Venerabile Capitulum Ecclesiae Collegiatae Loviciensis empto et comparato per eandem Annam Roszkowa dotatum, in eadem summa principali censuque annuo ab ea proveniente in honorem Dei Optimi Maximi sub titulo et invocatione sanctae Annae ${ }^{\dot{b}}$ erigendum decerni et erigi, et in beneficium ecclesiasticum capellaniamque [s. 348] perpetuam fundari. Contractu inter dictam Annam Roszkowa et venerabile capitulum praefatum super emptione et venditione census praedicti rebusque aliis praesens negotium concernentibus, ordinationemque tam super modo et ratione census praedicti persolvendi, quam divinorum ad hoc idem altare peragendorum facto, dieque vigesima quinta mensis Ianuarii anni praesentis pro parte dicti venerabilis capituli coram illustrissimo ac reverendissimo domino archiepiscopo Gnesnensi memorato exhibitis, tum et submissione per hoc idem venerabile capitulum eadem quoque die coram eodem illustrissimo ae reverendissimo domino archiepiscopo Gnesnensi, actisque curiae paternitatis suae illustrissimae ac reverendissimae sub sigillo eiusdem extracta ac mea actorum praesentium notarii manu subscripta exhibuit ${ }^{7}$, auctoritate ordinaria in omnibus et singulis punctis, clausulis, capitulis, articulis et conditionibus confirmari et approbari, ius patronatus eiusdem altaris

c dodat wyd. f publicat kop. $\mathrm{g}$ brak $w$ kop. h contumaciam kop.

37. 1 Tomasz rodem $z$ Uniejowa, proboszcz par. Boleszczyn w dek. tureckim.

2 Anna Roszkowa mieszczanka z Eowrcza, prawdop. wdowa.

$3 \quad$ Stanislaw Karnkowski - zob. nr 32, przyp. 1.

4 Kaplica fundacji rodziny Roszków z Lowicza, której przedstawicielka byla wspom. $w$ przyp. 2 Anna.

5 Kościól par. pw. Ducha $\$ w$. w Lowıczu - dok. fund. i erekc. pod nrem 2.

o Sw. Anna - por. nr 26, przyp. 11.

7 Wspom. kontrakt $i$ zobowiazania kapituly wobec Roszkowej zostaly wpis. do akt Karnkowskiego pod dn. 251 166'1 (Regesty zapisek, s. 103). 
dictae Annae Roszkowa quoad vixerit, post mortem autem eiusdem Venerabili Capitulo Ecclesiae Collegiatae Loviciensis temporibus perpetuis iuxta eiusdem ordinationis contenta reservari, et litteras desuper necessarias extradi mandari. ${ }^{j} \sim$ Excellens magnificus ${ }^{-1}$ Sebastianus Corvinus ${ }^{8}$ nomine ac in praesentia dominorum magistrorum ${ }^{k}$ totiusque Fraternitatis Sagittariorum Loviciensium ${ }^{9}$ comparens allegavit dictos suos principales pro suo interesse seu in re, quod ipsis ad dictam capellam ab antiquissimis et praescriptis temporibus, novissime vero ex sententia per illustrissimum ac reverendissimum dominum archiepiscopum Gnesnensem memoratum licet contra ipsos et in favorem praefatae Annae Roszkowa anno proxime praeterito, die vero secunda mensis Augusti lata ${ }^{\mathbf{1 0}}$ competit in termino huiusmodi comparere, non ea quidem intentione, ut fundationem seu erectionem dicti [s. 349] altaris impediant, sed solummodo ut de iure suo praemisso praesententur ac pro suo interesse in dictam fundationem et erectionem consentiant propellantque, ut ultra feriam tertiam Pentecosten ${ }^{11}$, qua sacrum missae sacrificium de Spiritu Sancto, dicta fraternitate praesente, sollemniter in dicta capella antiquitus consuevit cantari; vicissim certi aliqui dies in qualibet hebdomada fraternitati assignentur, quibus sacerdos eiusdem fraternitatis, cui ad praesens dicta fraternitas de certo annuo salario habitationeque providet, post autem, Deo adiuvante, certa aliqua fundatione providere in animo habet, in dicta capella ad hoc idem altare divina annuatim peragat, prout protestantur consentiuntque et petunt. Illustrissimus vero et reverendissimus dominus archiepiscopus Gnesnensis memoratus reliquos omnes et singulos sua ad praemissa interesse putantes debite citatos, non tamen per se aut per suos aliquos procuratores, tametsi ultra horam iudicii solitam fuerint expectati, comparentes, praemissis petitis minime contradicentes, contumaces pronuntiavit, ipsorumque contumacia minime obstante, dictum altare in capella praedicta in honorem Dei Optimi Maximi sub titulo et invocatione sanctae Annae, Beatissimae Deiparae Virginis Matris, erexit et in beneficium ecclesiasticum capellaniamque perpetuam fundavit, dictorum quingentorum ${ }^{12}$ florenorum Polonicalium summam, una cum censu viginti florenorum ab ea provenientium, eidem capellae et altari eiusque ministris per dictam Annam Roszkowa, post mortem vero illius per Venerabile Capitulum Ecclesiae Collegiatae Loviciensis praesentandum, qui ad hoc idem altare divina iuxta ordinationem praein-

1 obstantem kop. J-f w kop. skrót: Exc. m. k w kop. archimagistrorum po-

8 Sebastian Corvinus (Korwin) pewne starszy bractwa strzeleckiego $i$ król kurkowy w Lowiczu.

9 Bractwo Strzeleckıe (Luczników, Kurkowe) w Lowiczu ıstnalo juź od dluźszego czasu.

10 Dok. mszalny Karnkowskiego dla luczników towickich odnośnie kaplicy Roszków zostal wciag. do jego akt pod dn. 2 VIII 1600 (Regesty zapısek, s. 103).

11 Wtorek Zielonych Swiatek byl wtenczas obchodzony jako święto państwowe.

12 Wyzej byto powiedziane, ze 400 florenów. 
sertam annuatim peraget, annexit, ascripsit et incorporavit appropria[s. 350] vitque, et ut deinceps tam census, quam summa principalis supra nominata iuri libertati et immunitati ecclesiasticae subiaceat decrevit, contractum inter dictam Annam Roszkowa ex una et Venerabile Capitulum Ecclesiae Collegiatae Loviciensis parte ab altera super venditione emptioneque census huiusmodi initum, ordinationemque tam super solvendo censu, quam modo et ratione divinorum peragendorum factam, in eodem contractu descriptam, omniaque et singula eiusdem contractus contenta, tum et submissionem et obligationem per dictum venerabile capitulum factam admisit, confirmavit et approbavit. Ius patronatus vero et praesentandi ad hoc idem altare, quotiescumque illud per cessum vel decessum vacare contigerit, aliquem actu presbyterum eidem Annae Roszkowa respectu fundationis, quam dicta Anna Roszkowa fec1t, quoad vixerit, post mortem vero illius Venerabile Capitulum Ecclesiae Collegiatae Loviciensis, iuxta contenta contractus, de quo super facta est mentio, temporibus perpetuis reservavit. Porro quod attinet rationem et tempora divinorum in dicta capella et ad hoc altare peragendorum constituit, ordinavit ac praecepit, ut ii actu presbyteri, qui per praefatam Annam Roszkowa, seu post mortem illius per venerabile capitulum praedictum praesentabuntur, modo ac diebus et temporibus in contractu, de quo supra facta est mentio, descriptis, per se ipsos vel in eventu alicuius impedimenti legitimi per idoneum substitutum, sub poena excommunicationis, quam in eos et quemlibet illorum ex nunc tulit et promulgavit, ipso facto, nulla declaratione cuiusque subsecutura, incurrenda, et provisione dicta $^{1}$ dicto altari temporibus perpetuis divina peragere teneantur sintque astricti et obligati. Praedictae vero Fraternitati Sagittariorum Loviciensium ad peragenda in dicta capella divina, videlicet feriam tertiam [s. 351] festorum Pentecostes, duos dies in qualibet hebdomada, quos eadem fraternitas duxerit sibi eligendos, assignavit, quibus sacerdos ipsorum, cui de salario competenti, quousque aliquam certam eamque perpetuam fundationem pro illius sustentatione fecerint, providebunt. In dicta capella ad hoc idem altare sacrosanctae missae sacrificium peraget; et litteras desuper necessarias extradi mandavit, prout auctoritate ordinaria pronuntiat, erıgit, admittit, confirmat et approbat, reservat, constituit et ordinat assignatque, extradi mandat praemisso et omni meliore ${ }^{1}$ modo, vigore praesenti decreto ad praemissa mediante.

prawione na acsımagistrorum 1 dicto kop. 1 melior $k$ kop. 